Prepared in cooperation with the Colorado Geological Survey for the United States Department of Agriculture Forest Service

\title{
Development of Industrial Minerals in Colorado
}

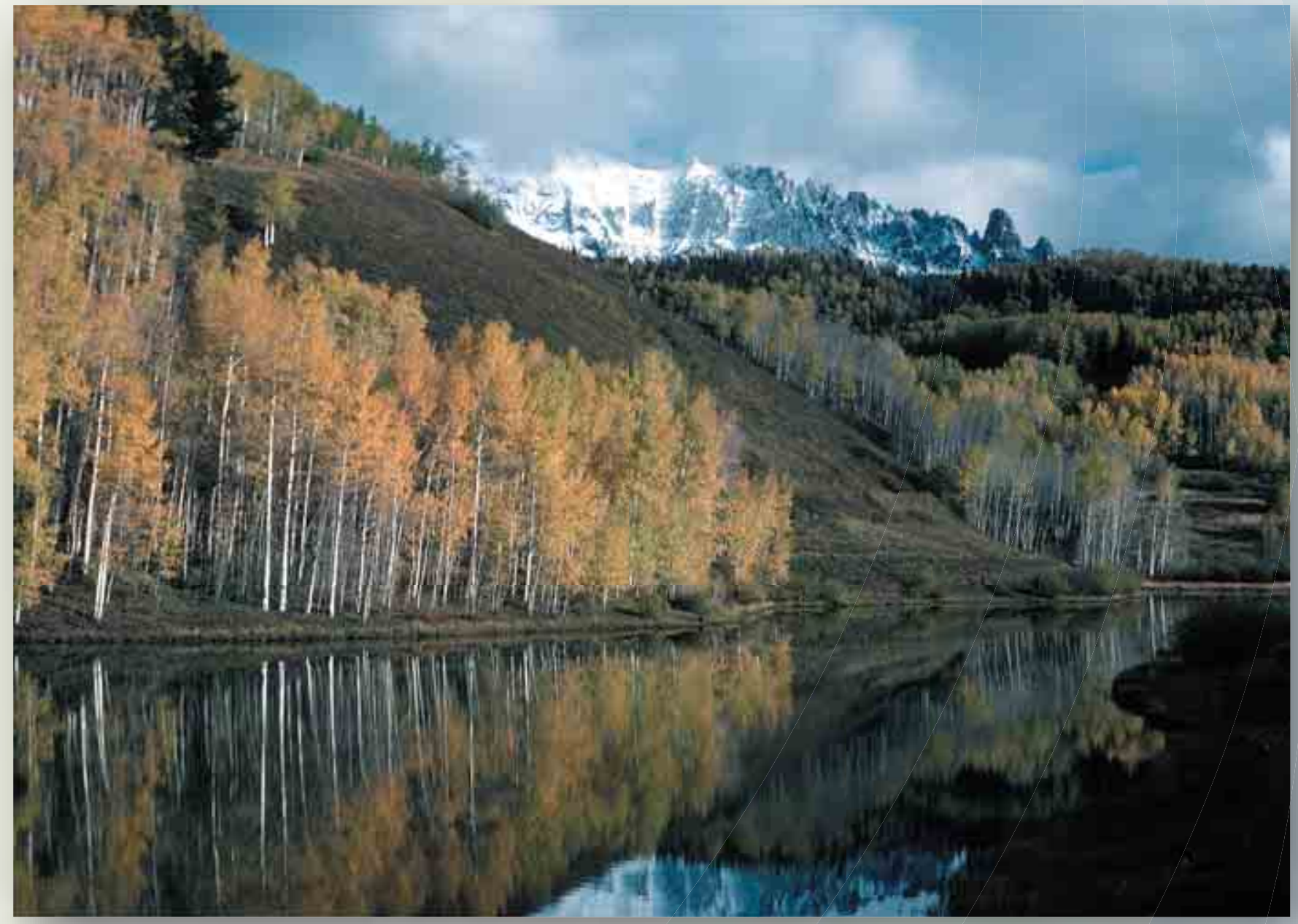

Circular 1368

U.S. Department of the Interior

U.S. Geological Survey 



\section{Development of Industrial Minerals in Colorado}

By Belinda F. Arbogast, Daniel H. Knepper, William H. Langer, Jr., James A. Cappa, John W. Keller, Beth L. Widmann, Karl J. Ellefsen, Terry L. Klein, Jeffrey E. Lucius, and John S. Dersch

Prepared in cooperation with the Colorado Geological Survey for the United States Department of Agriculture Forest Service

Circular 1368 


\section{U.S. Department of the Interior \\ KEN SALAZAR, Secretary \\ U.S. Geological Survey \\ Marcia K. McNutt, Director}

\section{U.S. Geological Survey, Reston, Virginia: 2011}

For more information on the USGS - the Federal source for science about the Earth, its natural and living resources, natural hazards, and the environment, visit http://www.usgs.gov or call 1-888-ASK-USGS

For an overview of USGS information products, including maps, imagery, and publications, visit http://www.usgs.gov/pubprod

To order this and other USGS information products, visit http://store.usgs.gov

Any use of trade, product, or firm names is for descriptive purposes only and does not imply endorsement by the U.S. Government.

Although this report is in the public domain, permission must be secured from the individual copyright owners to reproduce any copyrighted materials contained within this report.

Suggested citation:

Arbogast, B.F., Knepper, D.H., Langer, Jr., W.H., Cappa, J.A., Keller, J.W., Widmann, B.L., Ellefsen, K.J., Klein, T.L., Lucius, J.E., and Dersch, J.S., 2011, Development of industrial minerals in Colorado: U.S. Geological Survey Circular 1368, $87 \mathrm{p}$.

\section{Library of Congress Cataloging-in-Publication Data}

Development of industrial minerals in Colorado / Belinda F. Arbogast ... [et al.].

p. cm. -- (Circular ; 1368)

"Prepared in cooperation with the Colorado Geological Survey for the United States Department of Agriculture Forest Service."

Includes bibliographical references.

ISBN 978-1-4113-3118-1 (pbk.)

1. Mines and mineral resources--Colorado. I. Arbogast, B. F. (Belinda F.) II. Colorado Geological Survey. III. Geological Survey (U.S.)

TN24.C6D48 2011

$338.2^{\prime} 309788--d c 23$ 


\section{Contents}

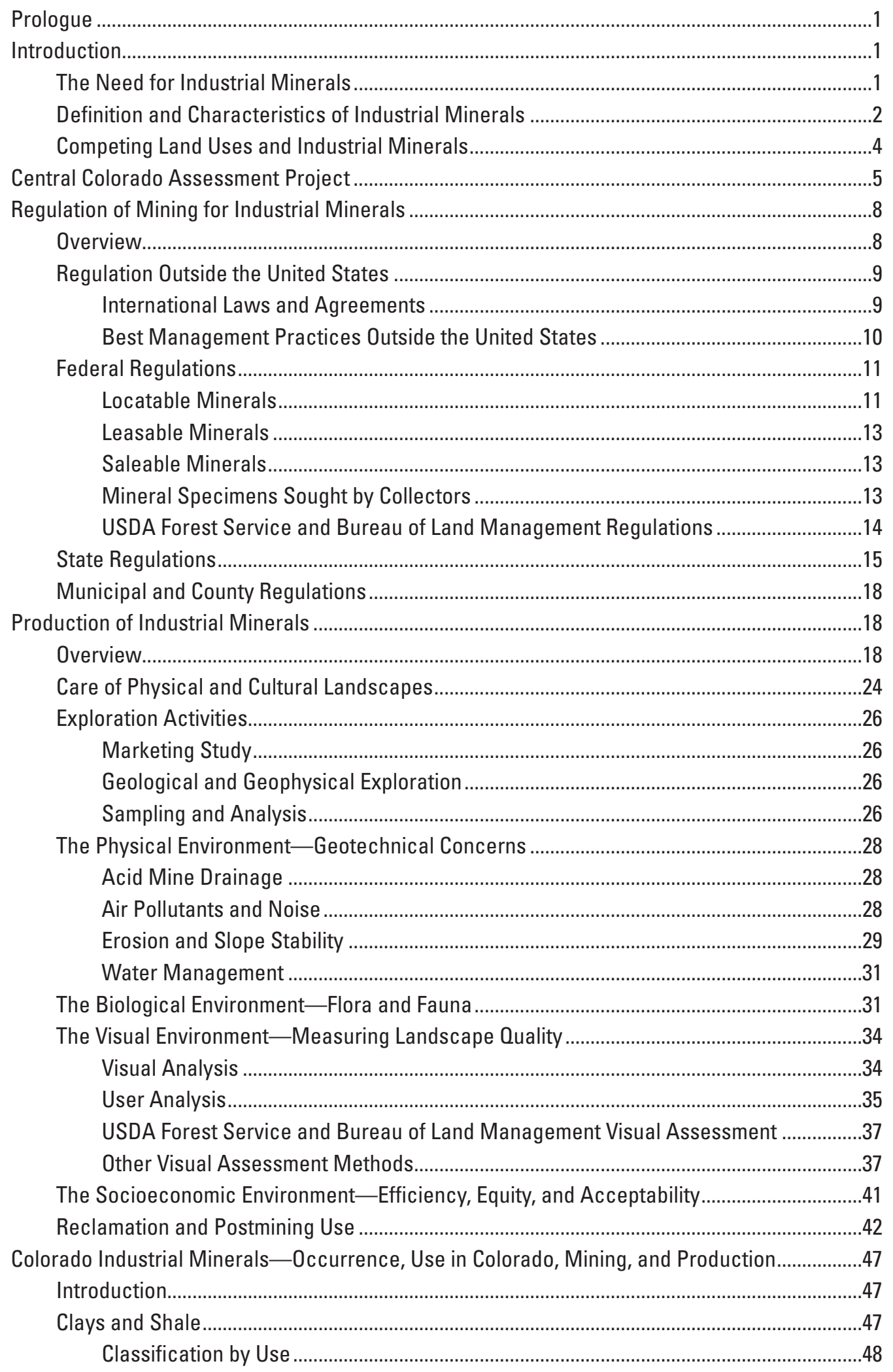


Geology of Colorado Clay and Shale Deposits ………….............................................

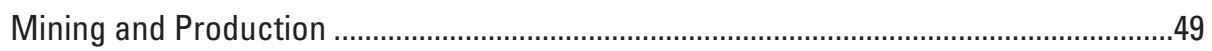

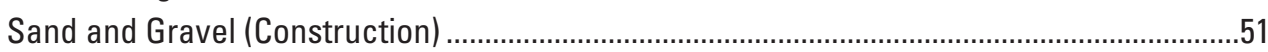

Geology of Colorado Sand and Gravel Deposits ............................................................52

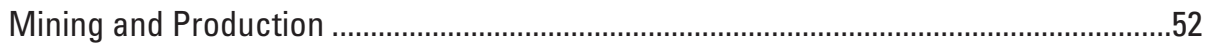

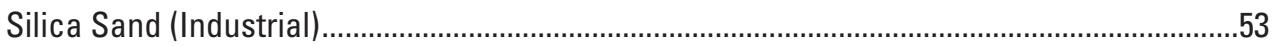

Geology of Colorado Silica Sand Deposits ...............................................................53

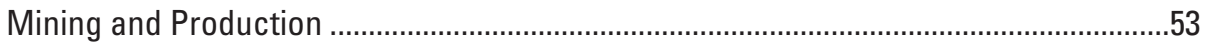

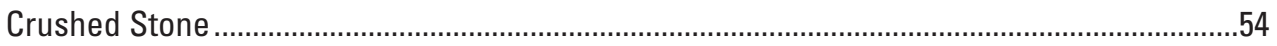

Geology of Colorado Crushed Stone Deposits.............................................................54

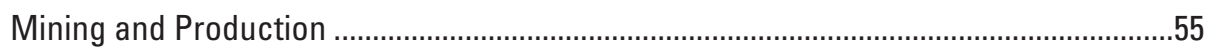

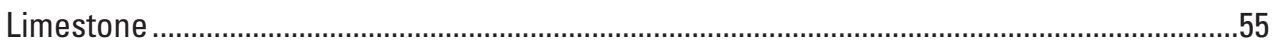

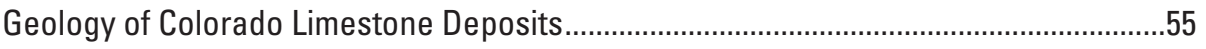

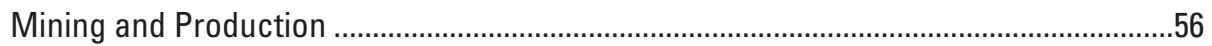

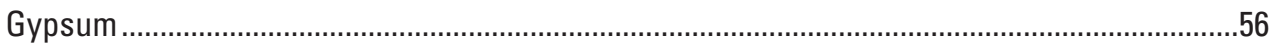

Geology of Colorado Gypsum Deposits................................................................56

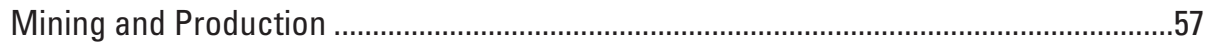

Lightweight Aggregates_Pumice, Scoria, Perlite, and Vermiculite ......................................59

Classification of Lightweight Aggregates................................................................59

Geology of Colorado Lightweight Aggregate Deposits ...............................................59

Mining and Production .............................................................................................. 60

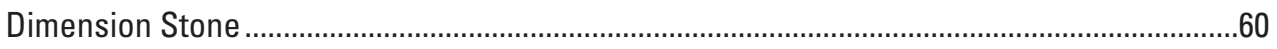

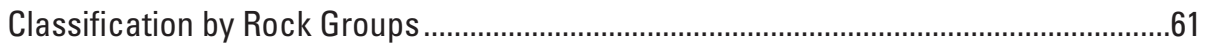

Geology of Colorado Dimension Stone Deposits...........................................................63

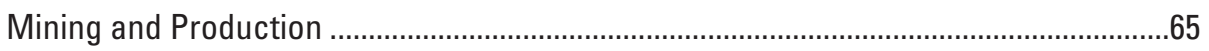

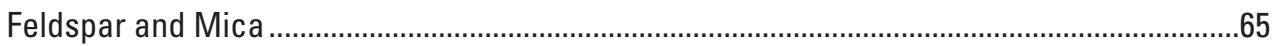

Geology of Colorado Feldspar and Mica Deposits ......................................................67

Mining and Production ...........................................................................................67

Sulfur

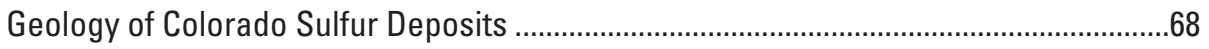

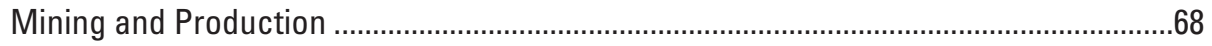

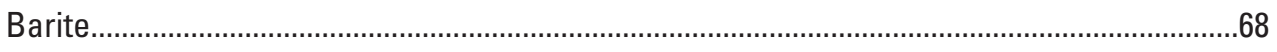

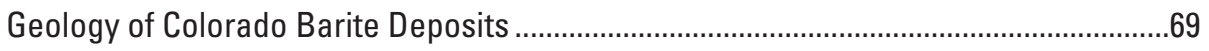

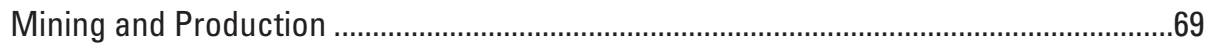

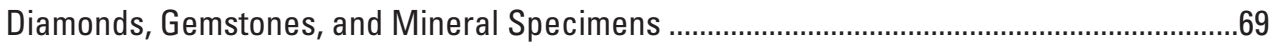

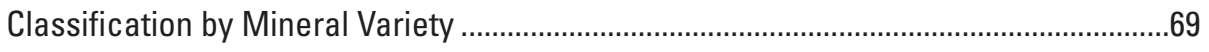

Geology of Colorado Gemstone and Hand Specimen Dep osits.....................................72

Mining and Production .............................................................................................

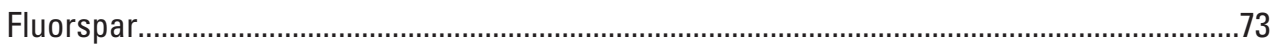

Geology of Colorado Fluorspar Deposits ..................................................................

Mining and Production ..........................................................................................

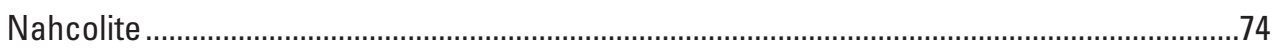

Geology of Colorado Nahcolite Deposits................................................................

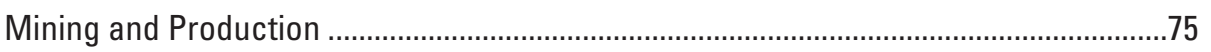

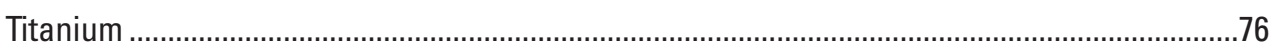

Geology of Colorado Titanium Deposits ..................................................................... 
Mining and Production .....................................................................................................

Zeolite ... .77

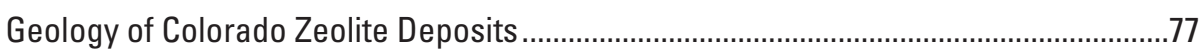

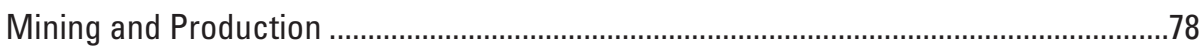

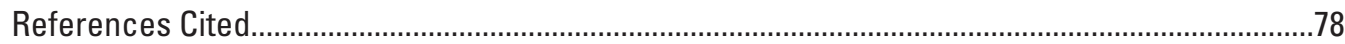

\section{Figures}

1. Photograph of stone villages at Mesa Verde National Park, southwestern Colorado.....2

2. Cartoon showing estimated lifetime use of minerals, metals, and fuels...........................2

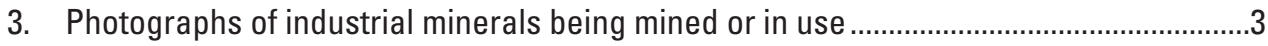

4. Photographs showing urban growth in Colorado .........................................................

5. Map of Colorado showing area of Central Colorado Assessment Project........................6

6. Map of Federal land, major mining districts, counties, and cities in Colorado ..................7

7-27. Photographs showing the following:

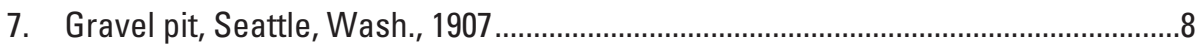

8. Mitigation methods used at open-pit mines.............................................................

9. Glensanda granite quarry, coastal Scotland .....................................................10

10. Recycled asphalt and concrete, Denver, Colorado ..............................................11

11. Thirteenth-century Puebloan structure in Canyons of the Ancients National

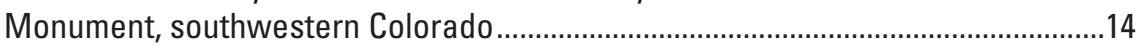

12. Mine sites or quarries preserved for recreational use .............................................17

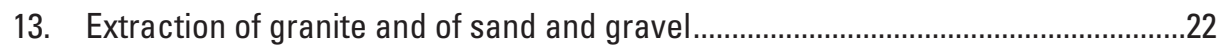

14. Landscapes that contain natural and manmade features.....................................25

15. Gravel tip and rocky outcrops, Wind River Reservation, Wyoming .........................25

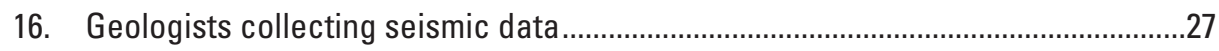

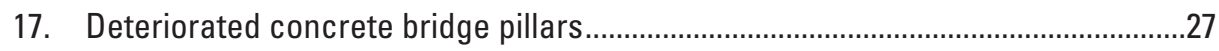

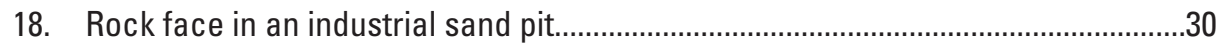

19. Wood fiber netting used to prevent erosion until grass is established...................30

20. Sedimentation pond at a coal mine site near Craig, Colorado ................................31

21. Columbian sharp-tailed grouse and reclaimed mine land near Craig, Colorado....32

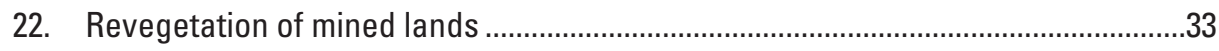

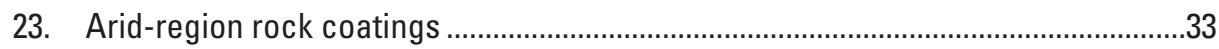

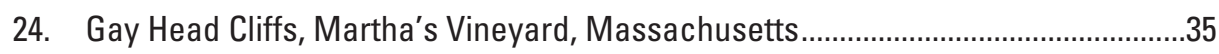

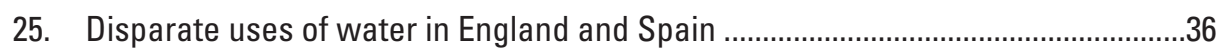

26. Landscape in Yellowstone National Park...............................................................36

27. Natural landscape features that mimic manmade features .....................................40

28. Wood block print of mineral beneficiation in the 1500s

29-37. Photographs showing the following:

29. Before and after quarry restoration, Arkansas .....................................................4

30. Reclamation work at Howe pit, Colorado ............................................................43

31. Natural and manmade camouflage of a gravel pit, Colorado .................................4

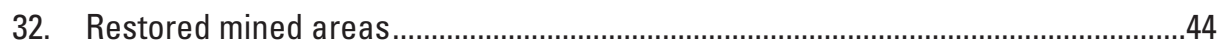

33. Reclaimed mined land that serves community needs.............................................45 
34. Quarries used to educate the public about mining ..................................................

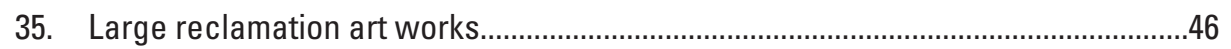

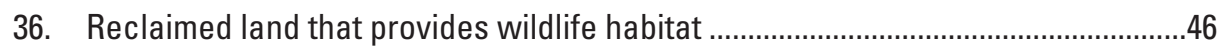

37. Landscapes incorporating historical mining structures ............................................4

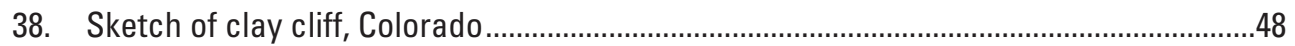

39-61. Photographs showing the following:

39. Fire clay, sandstone, and shale in Dakota Sandstone hogback ................................50

40. Poor drainage on bentonite, Albany County, Wyoming .............................................50

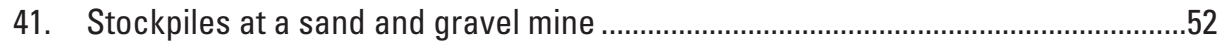

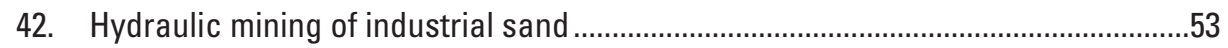

43. Limestone quarries..............................................................................................56

44. Gypsum-containing construction materials and a gypsum mine ............................57

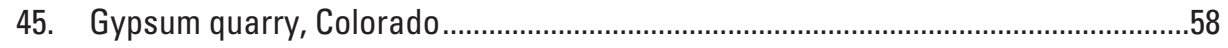

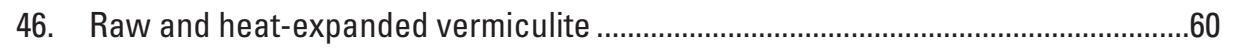

47. Dimension stone being processed and in use .......................................................61

48. Granite used as building facing and sketch of granite outcrop. .............................62

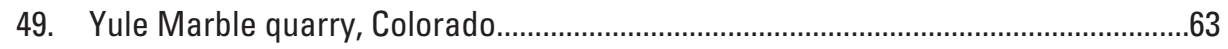

50. Lyons Sandstone in outcrop and in use ..............................................................64

51. Contact between Sawatch Quartzite and Pikes Peak Granite ..................................65

52. Mica in outcrop and in scanning electron micrograph ...........................................66

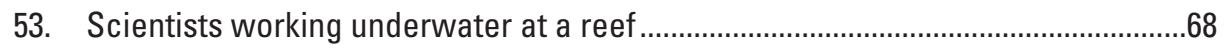

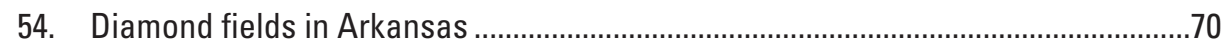

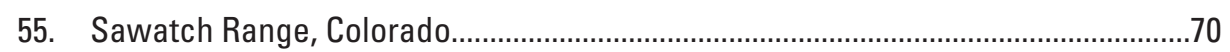

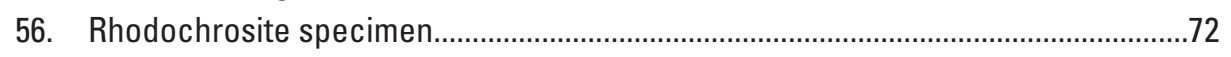

57. Nelly E garnet mine, Colorado ............................................................................

58. Fault zone between Tertiary rhyolite tuff and Precambian rocks ............................75

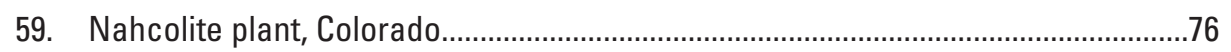

60. Zeolite as seen in a scanning electron micrograph .............................................77

61. Small zeolite production pit, Oregon .....................................................................78

\section{Tables}

1. Preliminary population forecasts for Colorado by region, 2000-2030 ..............................4

2. Typical Federal conservation laws or policies and their implications for mining............12

3. Typical State policies and their implications for mining ..............................................16

4. Typical county or municipal policies and their implications for mining ..........................19

5. Principal industrial minerals of Colorado—uses and source areas................................20

6. Average unit price of and industry efforts to conserve deposits of certain mineral

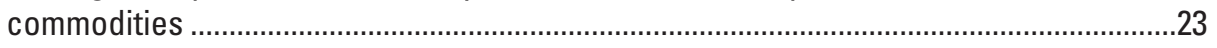

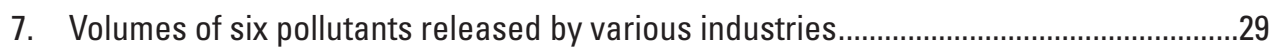

8. Clay processing operations by type of clay ............................................................... 


\section{Conversion Factors}

\begin{tabular}{lll}
\hline Multiply & By & To obtain \\
\hline kilometer $(\mathrm{km})$ & 0.6214 & mile (mi) \\
meter $(\mathrm{m})$ & 3.281 & foot (ft) \\
meter $(\mathrm{m})$ & 1.094 & yard (yd) \\
centimeter $(\mathrm{cm})$ & 0.3937 & inch (in.) \\
micrometer $(\mu \mathrm{m})$ & 3.937 & inch (in.) \\
\hline
\end{tabular}

\section{Abbreviations Used in This Report}

\section{Abbreviated units used in this report}

$\begin{array}{ll}\mathrm{Ga} & \text { giga-annum; billions of years ago } \\ \mathrm{Ma} & \text { mega-annum; millions of years ago } \\ \mu \mathrm{m} & \text { micrometer (1 millionth meter) } \\ \mathrm{cm} & \text { centimeter or centimeters } \\ \mathrm{ft} & \text { Foot or feet } \\ \mathrm{in} . & \text { inch, inches } \\ \mathrm{lb} & \text { pound } \\ \mathrm{m} & \text { meter, meters } \\ \mathrm{mm} & \text { millimeter, millimeters }\end{array}$

\section{Abbreviated terms used in this report}

$\begin{array}{ll}\text { B.C.E. } & \text { Before Common Era } \\ \text { BLM } & \text { U.S. Bureau of Land Management } \\ \text { USDA } & \text { U.S. Department of Agriculture } \\ \text { USGS } & \text { U.S. Geological Survey } \\ \text { ISO } & \text { International Organization for Standardization }\end{array}$





\title{
Development of Industrial Minerals in Colorado
}

\author{
By Belinda F. Arbogast, ${ }^{1}$ Daniel H. Knepper, ${ }^{1}$ William H. Langer, ${ }^{1}$ Jr., James A. Cappa, ${ }^{2}$ John W. Keller, ${ }^{2}$ \\ Beth L. Widmann, ${ }^{2}$ Karl J. Ellefsen, ${ }^{1}$ Terry L. Klein, ${ }^{1}$ Jeffrey E. Lucius, ${ }^{1}$ and John S. Dersch ${ }^{3}$
}

\section{Prologue}

Humans use technology to alter nature and landscapes in order to survive, express themselves, and suit their activities. The natural landscape changes, whereas we seek stability. We shape the landscape through science and art; through mining, managing national forests, constructing water reservoirs, and urban development. The societal values we attach to various resources reflect our culture, experience, education, and many other factors. Both culture and society's approach to resource management change over time.

Natural landscapes face competition through increasing human populations and pressures from agriculture, housing, recreation, and mineral extraction. Humans have the capacity to create a wide variety of environments. We can create landscapes that satisfy our basic need for food, minerals, timber, and even wilderness.

Technology and engineering have helped make mining safer and cleaner for both humans and the environment. Inevitably, mineral development entails costs as well as benefits. Developing a mine is an environmental, engineering, and planning challenge that must conform to many Federal, State, and local regulations. "The mining legacy in the Rocky Mountain region, though sometimes environmentally destructive in the past, left 'simple and powerful structural forms [that] continue to inspire new designs'” (U.S. Department of Agriculture Forest Service, 2001, p. 163).

Community collaboration, creative design, and best management practices of sustainability and biodiversity can be positive indicators for the mining industry. A better understanding of aesthetics, culture, economics, geology, climate, vegetation and wildlife, topography, historical significance, and regional land planning is important in resolving land-use issues and managing mineral resources wisely. Ultimately, the consuming public makes choices about product use (including water, food, highways, housing, and thousands of other items) that influence operations of the mineral industry. Land planners, resource managers, earth scientists, designers, and public groups have a responsibility to consider sound scientific

${ }^{1}$ U.S. Geological Survey, MS 973, Box 25046, Denver, CO 80226

${ }^{2}$ Colorado Geological Survey, 1313 Sherman Street, Denver, CO 80203

${ }^{3}$ USDA Forest Service, POB 25127, Lakewood, CO 80225 information, society's needs, and community appeals in making smart decisions concerning resource use and how complex landscapes should change.

An effort to provide comprehensive geosciences data for land management agencies in central Colorado was undertaken in 2003 by scientists of the U.S. Geological Survey and the Colorado Geological Survey. This effort, the Central Colorado Assessment Project, addressed a variety of land-use issues in the Colorado Front Range, North Park, Middle Park, and South Park, and in the Gore Range, Mosquito Range, Sawatch Range, and Sangre de Cristo Mountains. Among the goals of the project was an understanding of the availability of industrial and metallic rocks and minerals, the geochemical and environmental effects of historic mining activity on surface water and groundwater, and the geologic controls on the availability and quality of groundwater.

For instance, large tracts of U.S. Department of Agriculture (USDA) Forest Service lands, which compose the majority of Federally administered lands in the Central Colorado Assessment Project, are underlain with sand and gravel or stone resources that could be used for construction purposes. The USDA Forest Service and other land management agencies have the opportunity to contribute to the sustainable management of natural aggregate and other mineral resources through the identification and selective development of mineral resources and the reclamation of mines on lands that they administer. The information in this Circular will help them carry out that task.

\section{Introduction}

\section{The Need for Industrial Minerals}

If you are reading this publication, you are using industrial minerals. Clay and chemicals made from other industrial minerals are used to make paper and ink. Without industrial minerals, there would be no roads, rail lines, or airports to deliver oranges from Florida or salmon from Alaska. There would be no foundations for our homes, schools, and commercial buildings, no insulated walls to keep out the cold, no paint, no bike paths, no rubber tires, and certainly no computers. Without industrial minerals, society as we know it would cease to exist. 
On a small scale even prehistoric cultures and preindustrial Native Americans mined and used industrial minerals. In Colorado, Clovis period sites (dated between 11,200 and 10,900 Before Common Era (B.C.E.)) have yielded projectile points and tools crafted from fine-grained rock and bone (Stone, 1999). At the Black Dumps site in the mountains of the San Isabel National Forest, Chaffee County (Prasciunas, 2003), Ancestral Puebloan and other peoples mined clay and sand for dwellings, pots, and decorative items; turquoise for trade, jewelry, and art; and cryptocrystalline quartz (flint or chert) for tool making (Murphy and Modreski, 2002). Obsidian, chalcedony, and other forms of glassy silica were quarried and used to manufacture tools and weapons. Crystalline igneous and metamorphic rocks were used as grinding implements. Prehistoric stone tools made from Colorado rocks have been found throughout the Rocky Mountain region (T. McMahon, written commun., 2003). Colorado's first national park, Mesa Verde (west of Durango), was created in 1906 to preserve ancient Native American cliff dwellings built of stone (Noel and others, 1994) (fig. 1).

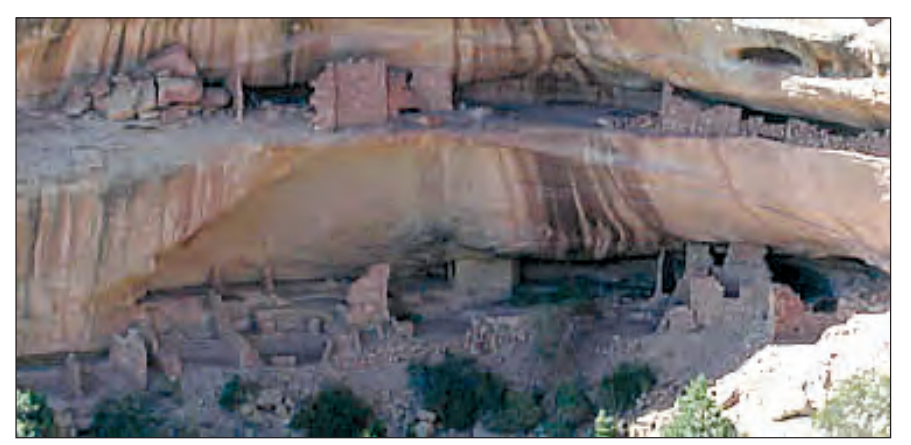

Figure 1. Elaborate stone villages built in sheltered alcoves of canyon walls at Mesa Verde National Park, southwestern Colorado. Archeological sites range from pit houses built during the 500 s to cliff dwellings of the 1200s. Courtesy of National Park Service.

Today, we depend on a staggering amount of industrial minerals. On average, in a year each American makes use of 12,695 pounds (lb) of stone, 8,945 lb of sand and gravel, $895 \mathrm{lb}$ of cement, $361 \mathrm{lb}$ of phosphate, and $304 \mathrm{lb}$ of clay, among other minerals (Dorr and Paty, 2002) (fig. 2). Moreover, the largest user of industrial minerals, the construction industry, continues to grow in the United States. It accounts for most of the consumption of clay, cement, glass, sand and gravel, crushed and dimension stone, and steel (U.S. Geological Survey, 2004). For example, crushed stone and sand and gravel produced in the United States has increased from about 58 million tons in 1900 to 2.3 billion tons in 1996 (Tepordei, 1999). Tepordei (1999) expected that by 2020 United States production of crushed stone will increase by more than 20 percent while sand and gravel will increase by 14 percent. Relatively small amounts of material from demolished buildings are recycled because construction aggregate is usually abundant and inexpensive to produce. Transportation costs are
Every American Born Will Need . . .

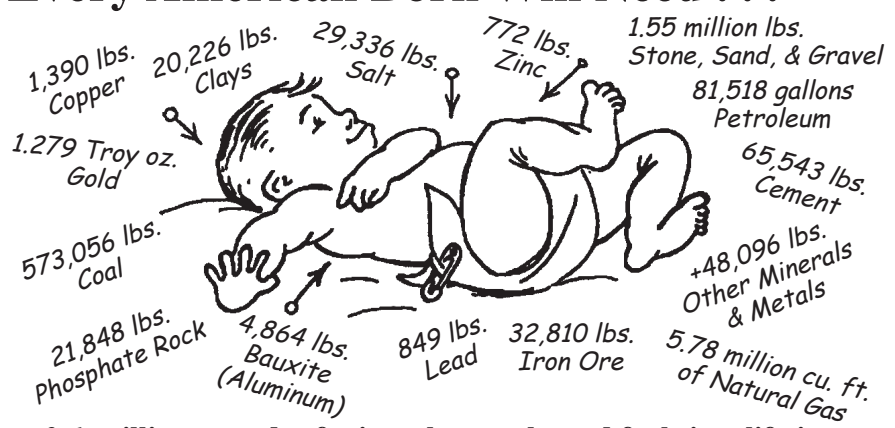

3.6 million pounds of minerals, metals, and fuels in a lifetime (c) 2004 Mineral Information Institute Golden, Colorado

Figure 2. Estimated amounts of minerals, metals, and fuels used in a lifetime in the United States. Natural resources are developed to meet this need. Courtesy of (C) Mineral Information Institute, Golden, Colo.

a major economic factor in the development of construction materials. Sand, gravel, and crushed stone are construction materials that typically undergo little or no processing before being used. Larger blocks of resistant stone (riprap) are needed to protect riverbanks, harbors, or shorelines from erosion. Smaller rocks are needed for railway ballast. Clay or ground shale can be formed and kiln dried into bricks used for construction (fig. 3). Other construction materials require additional processing, such as the sawing and polishing of granite for countertops.

\section{Definition and Characteristics of Industrial Minerals}

Minerals are natural inorganic substances that are “**** the raw material on which all economic activity and life itself ultimately depend” (Daly and Farley, 2004, p. 74). Society requires certain minerals used in industry that are mined, quarried, or extracted from the Earth's surface. The term "industrial mineral" applies to economically valuable geologic materials that are neither metals nor fuels; these minerals may be used for construction (such as sand and gravel or stone), agriculture (such as phosphate in fertilizers and insecticides), or industrial processes.

Mineral aggregates are valuable because of characteristics such as their bulk, weight, durability, compressive strength, lack of chemical reactivity, uniform composition, and other special features such as color, insulating value, and texture (McCarl, 1994). The most useful mineral aggregates are free of chemically reactive constituents, especially the following: cement alkalis and unstable or noncrystalline forms of silica that react with each other to form an alkali-silica gel that may accelerate deterioration of concrete structures; zeolites and clays formed in weathered or hydrothermally altered rocks; and unstable iron minerals, particularly in the aggregate used in concrete, that oxidize and cause the concrete to develop rust stains, change volume, and lose strength (Christie and others, 2001a). 

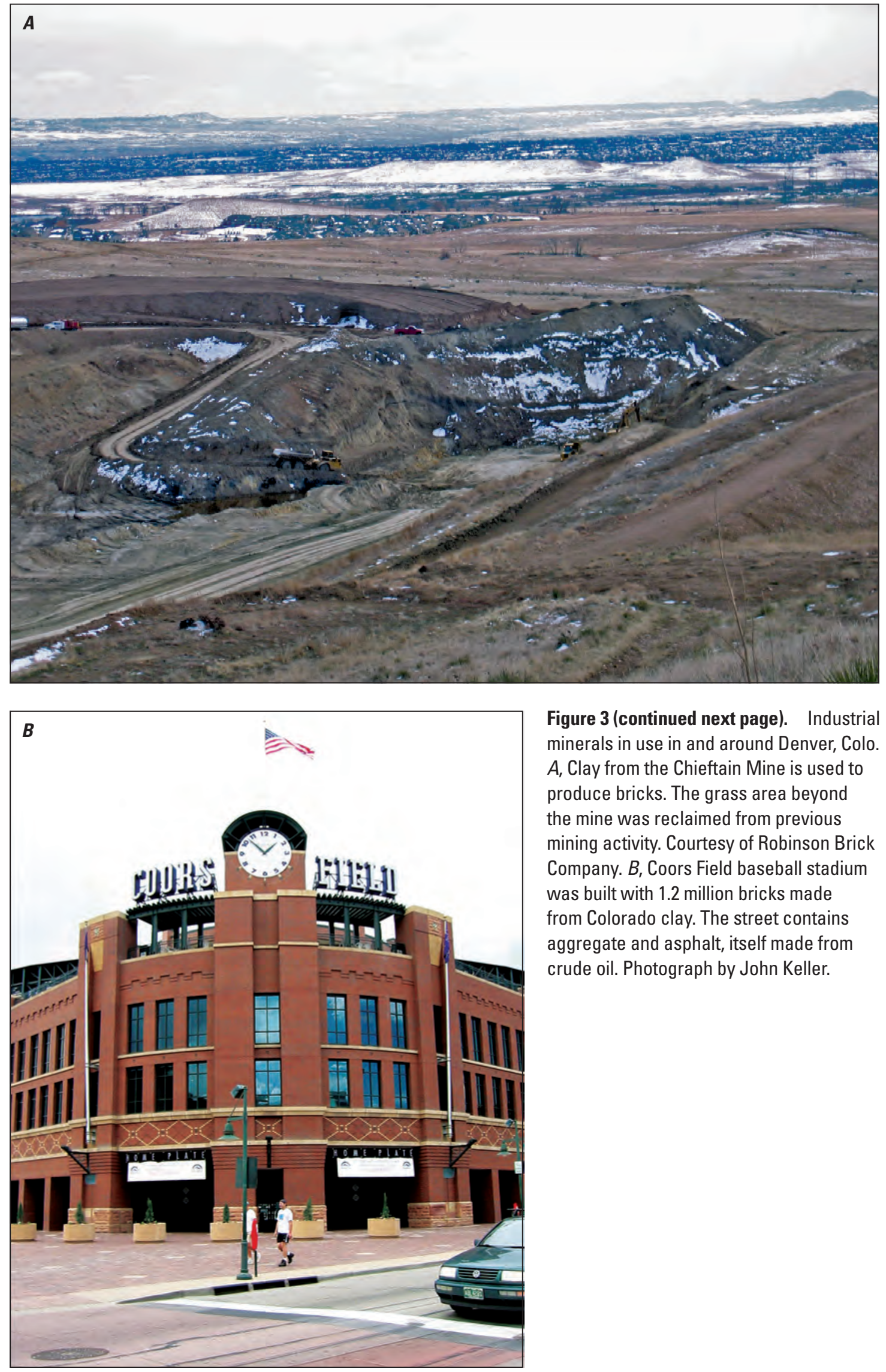

Figure 3 (continued next page). Industrial minerals in use in and around Denver, Colo. $A$, Clay from the Chieftain Mine is used to produce bricks. The grass area beyond the mine was reclaimed from previous mining activity. Courtesy of Robinson Brick Company. $B$, Coors Field baseball stadium was built with 1.2 million bricks made from Colorado clay. The street contains aggregate and asphalt, itself made from crude oil. Photograph by John Keller. 

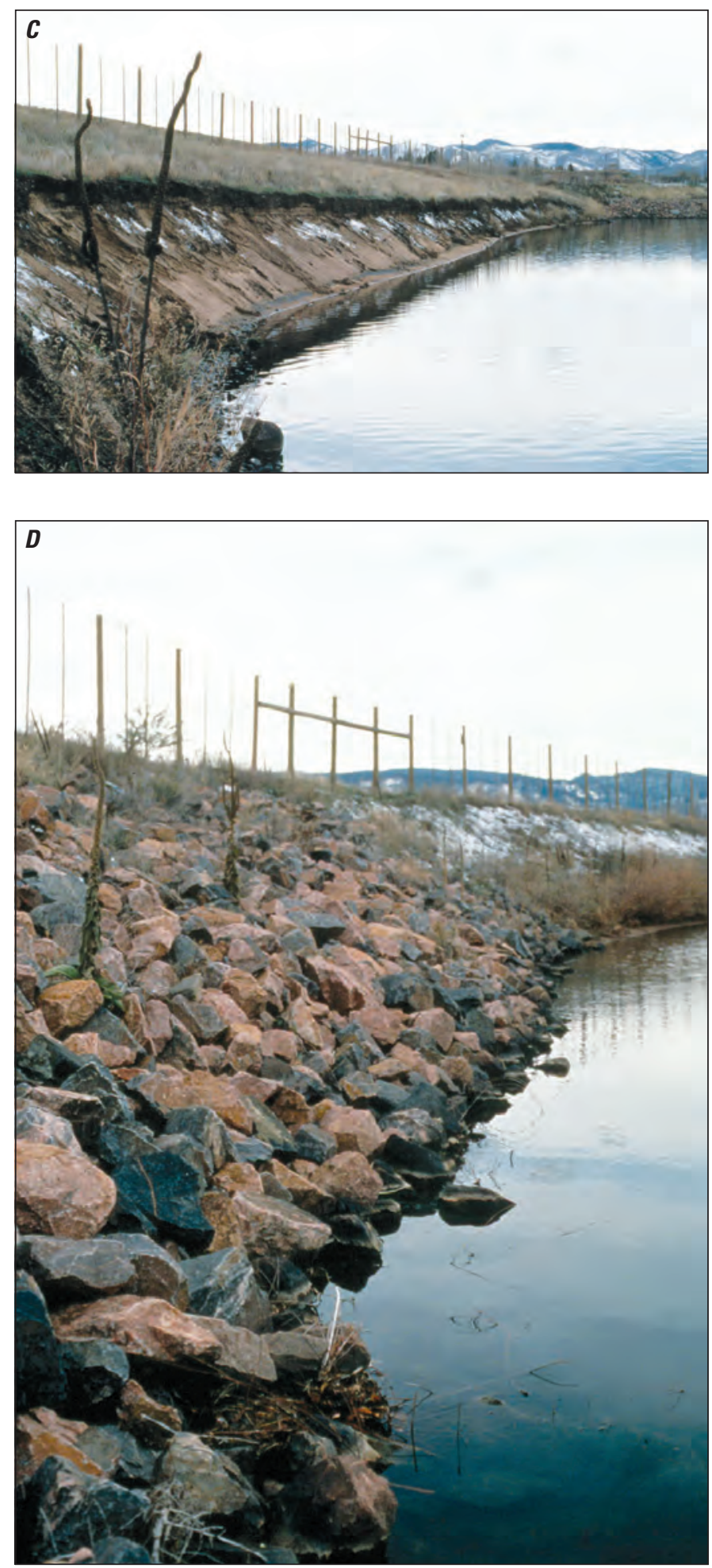

Figure 3 (continued). Industrial minerals in use in and around Denver, Colo. Shoreline of a reclaimed sand and gravel pit at South Platte Park (southwestern Denver metropolitan area) before $(C)$ and after (D) riprap (coarsely broken rock) was set in place to prevent erosion. Photographs $C$ and $D$ by Raymond Sperger.

\section{Competing Land Uses and Industrial Minerals}

Between 1900 and 2003, the population of Colorado grew from 539,700 to approximately 4.55 million people (U.S. Census Bureau, 2004). The State was projected to have 5.19 million people by 2025. Colorado’s Front Range urban corridor, which stretches about $350 \mathrm{~km}$ (217 mi) north and south of Denver - to Pueblo in the south and to the Colorado-Wyoming border in the north-is one of the fastest growing regions in the western United States (table 1). This population growth puts pressure on resources and has created many land management controversies for local, State, and Federal agencies. Growing public demand for outdoor recreation, scenery, and open space will compete with resource demands (Bastian and others, 2002).

The Front Range urban corridor experience has been true elsewhere (fig. 4). Nearly four out of every five people in the United States live in one of 273 metropolitan regions (Daniels, 1999), and these regions tend to be the locus of conflicts between land use and mining. The public desires amenities that contain industrial minerals, but it also wants mining operations to be located away from their communities.

The public good and protection of the environment is best served by sound scientific methodologies, current technology, and effective communication. Scientists, through research and increasingly comprehensive databases, attempt to provide land-use planners and resource managers a variety of information at a variety of scales: site (for example, a mine's effect on nearby flora and fauna), local (for example, its effect on roads or air quality in the surrounding neighborhood), and regional (for example, its effect on a watershed). Land planners and managers, workers in the mineral industries, regulators, and the general public all have a responsibility to be informed about the development of industrial minerals.

Table 1. Preliminary population forecasts for Colorado by region, 2000-2030 (modified from Colorado Department of Local Affairs Division of Local Government, 2005).

\begin{tabular}{lrrrr}
\hline \multicolumn{1}{c}{ Regions } & Estimated & \multicolumn{3}{c}{ Projected } \\
\cline { 3 - 5 } & $\mathbf{2 0 0 0}$ & \multicolumn{1}{c}{} \\
\cline { 3 - 5 } & & $\mathbf{2 0 1 0}$ & \multicolumn{1}{c}{$\mathbf{2 0 2 0}$} & \multicolumn{1}{c}{$\mathbf{2 0 3 0}$} \\
\hline Front Range & $3,538,770$ & $4,226,658$ & $4,993,836$ & $5,803,275$ \\
\hline Western Slope & 468,388 & 586,216 & 763,681 & 942,525 \\
\hline Central Mountains & 126,191 & 154,016 & 209,123 & 272,104 \\
\hline San Luis Valley & 46,435 & 52,124 & 58,169 & 62,996 \\
\hline Eastern Plains & 159,024 & 177,387 & 210,903 & 244,238 \\
\hline
\end{tabular}




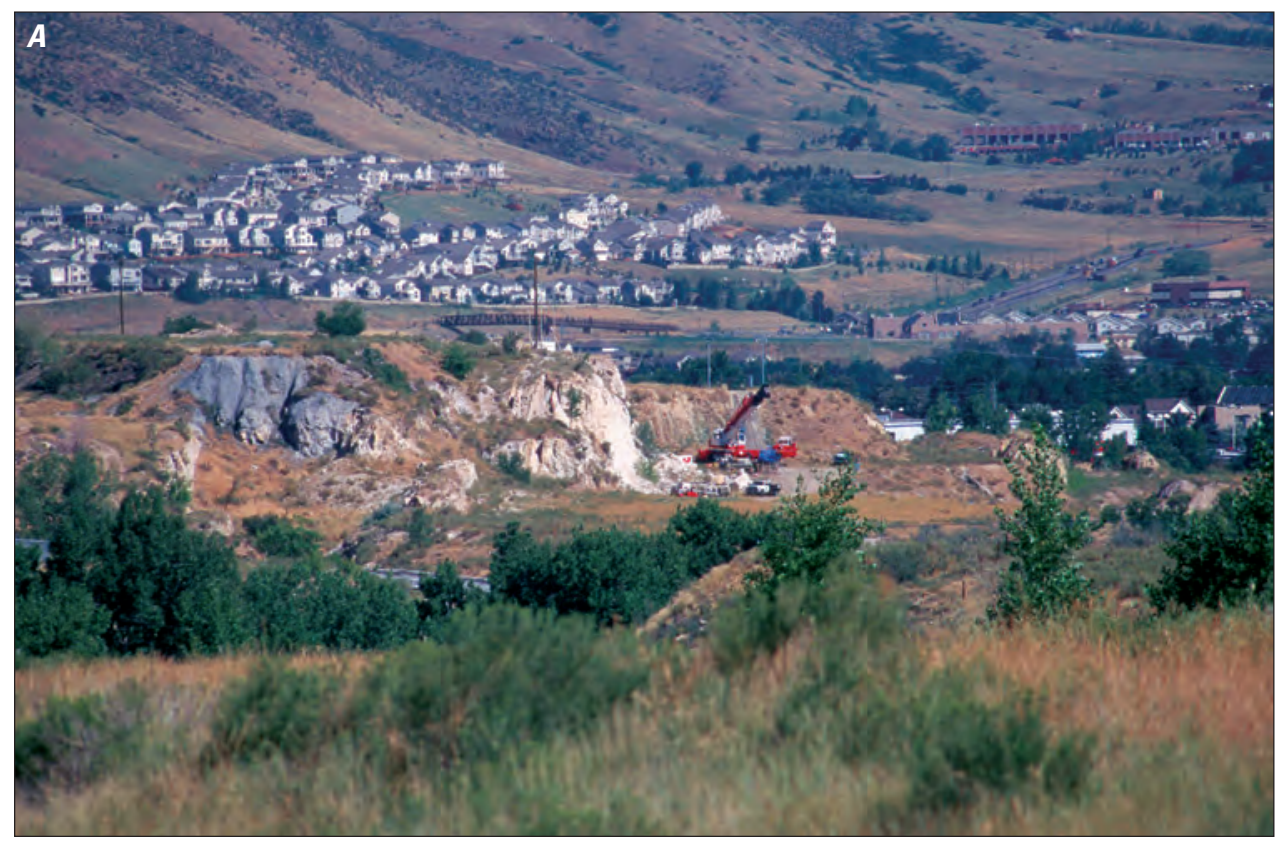

Figure 4. Urban growth in Colorado; such growth increases the demand for industrial minerals. $A$, Housing will soon compete with a clay pit for land use in Golden, 2002. B, Edwards, a bedroom community about 13 miles west of Vail, viewed from Interstate Highway 70 . A sand and gravel operation is in the foreground. Aggregate mining is necessary for the construction of infrastructure in Edwards, the fastest growing community in Eagle County. Photographs by B. Arbogast, 2004.

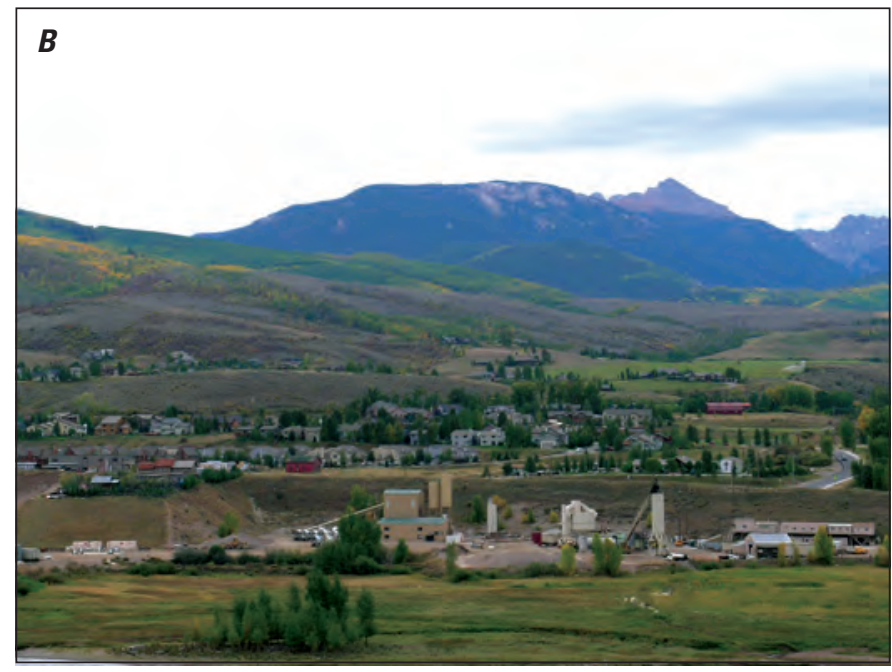

\section{Central Colorado Assessment Project}

An effort to provide comprehensive geosciences data for land management agencies in central Colorado was started in 2003 by scientists of the U.S. Geological Survey and the Colorado Geological Survey. This effort, the Central Colorado Assessment Project, addressed a variety of land-use issues in the Colorado Front Range, in North Park, Middle Park, and South Park, and in the Gore Range, Mosquito Range, Sawatch Range, and Sangre de Cristo Mountains (fig. 5). Among the goals of the project were an understanding of the availability -in terms of balancing competing uses desired for a given parcel of land — of industrial and metallic rocks and minerals used by industry and in construction, the geochemical and environmental effects of historic mining activity on surface water and groundwater, and the geologic controls on the availability and quality of groundwater.

Large tracts of USDA Forest Service lands, which compose the majority of Federally administered lands in the Central Colorado Assessment Project, are underlain by sand and gravel or by rock suitable for construction. These resources could be used for applications such as polished or rough-cut dimension stone, landscaping materials, and concrete- $-\mathrm{a}$ mixture of cement, fine aggregate (such as sand), coarse aggregate (such as gravel), and water. The USDA Forest Service and other land management agencies have the opportunity to contribute to the sustainable management of natural aggregate and other mineral resources through the identification and selective development of mineral resources, followed by appropriate reclamation of lands that they administer.

The USDA Forest Service is responsible for managing 191.6 million acres in the national forest system, about 8.3 percent of the land in the United States (USDA Forest Service, 2005). This report is a first step in opening a discussion about the need for and use of industrial minerals in the Rocky Mountain region's national forests and public lands (fig. 6). The terms "public land" and "public domain" can be used interchangeably; both terms refer to land owned by the Federal government for the benefit of citizens.

The original public domain contained lands that were turned over to the Federal Government by the colonial States and the areas acquired later from native Indian nations or 


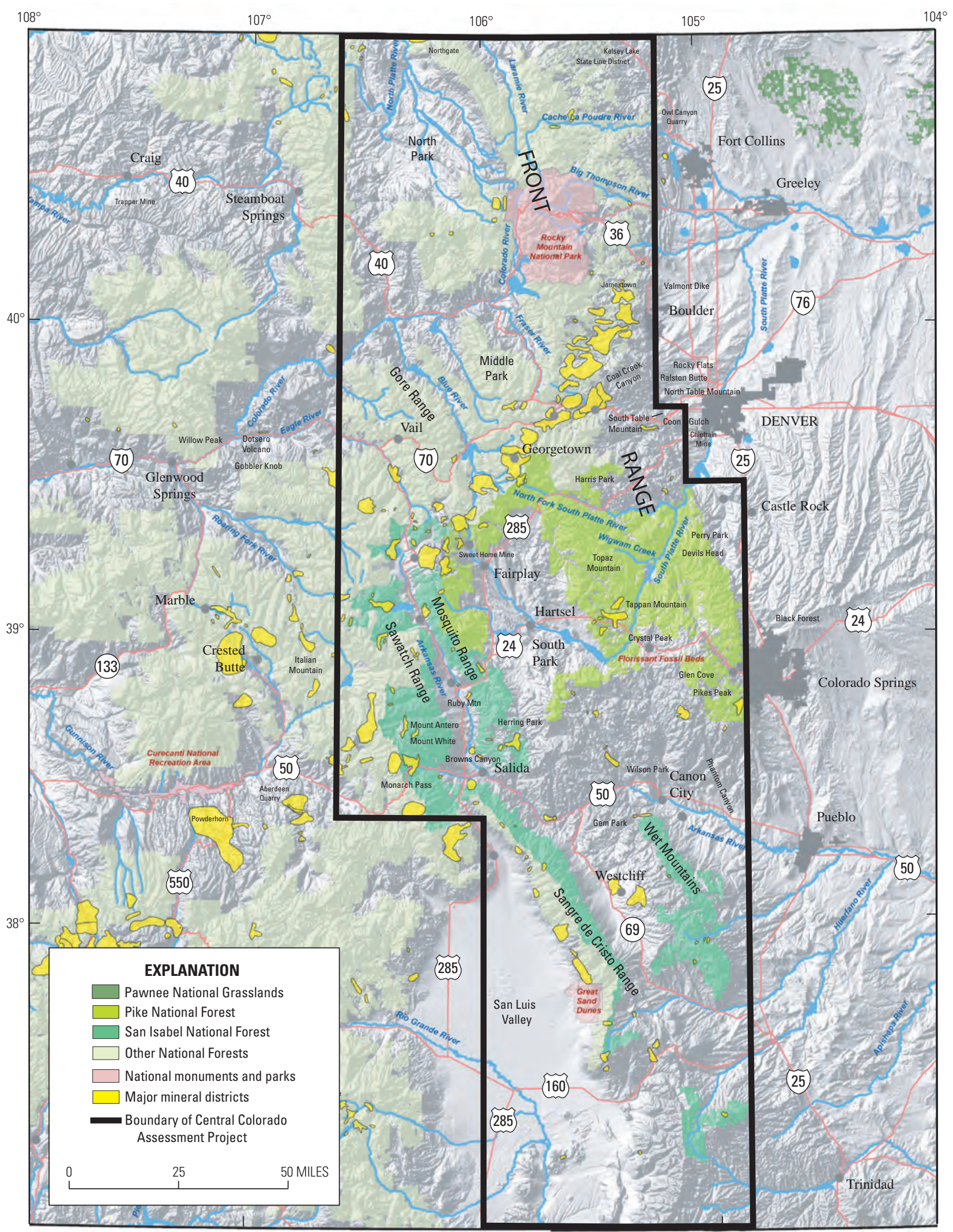

Figure 5. Colorado showing area of the Central Colorado Assessment Project (outlined in black). 


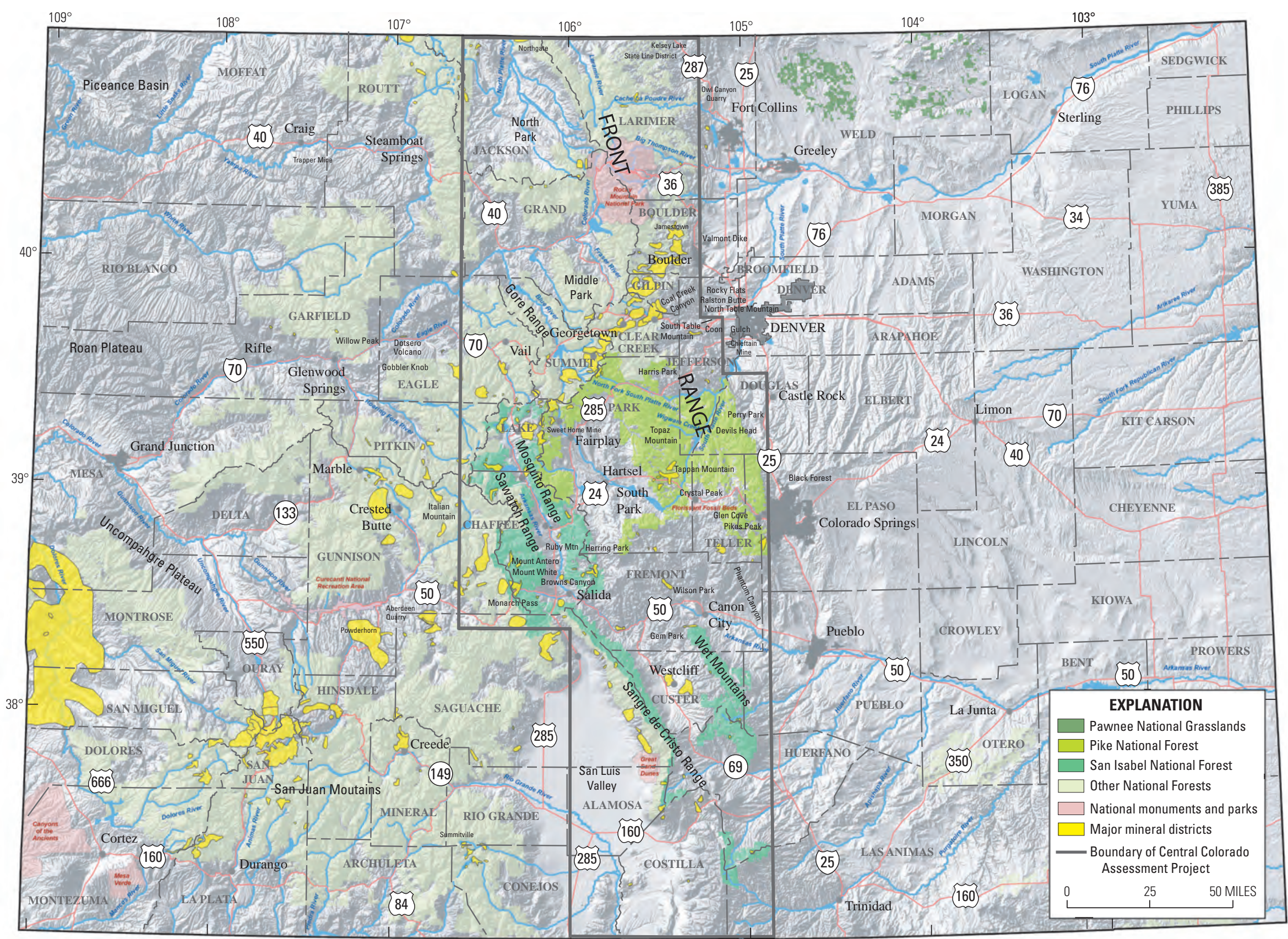

Figure 6. Federal land, major mining districts, counties, and cities in Colorado. Gray border, boundary of Central Colorado Assessment Project. 
foreign powers (U.S. Department of the Interior National Atlas of the United States, 2005). Overall, the Federal government owns approximately one-third of United States land; Federal lands account for as much as 86 percent of the land in certain Western States. Some Federal land is close to major metropolitan areas or to rural communities. The agencies managing most of the Federal land are as follows:

- USDA Forest Service

- Bureau of Land Management

- Fish and Wildlife Service

- National Park Service

- Bureau of Indian Affairs

- Bureau of Reclamation

- Army Corps of Engineers

"Use of the public lands has changed throughout our Nation's history and continues to evolve. Originally viewed as the Great American Desert, these [Western] lands over time came to be regarded primarily as a source of livestock forage, timber, and energy and mineral resources. Today, the public lands are valued more and more for their environmental resources, the recreational opportunities they offer, the cultural resources they contain, and, in an increasingly urban world, their vast open spaces" (U.S. Bureau of Land Management, 1997).

\section{Regulation of Mining for Industrial Minerals}

\section{Overview}

Mineral resources, along with land and water, once seemed to be inexhaustible commodities, and there appeared to be little concern about environmental damage (fig. 7). Today, the law, environmental regulations, and best management practices mitigate damaging effects of mining. The General Mining Act of 1872 encouraged mineral exploration and development on vacant public lands but excluded lands in

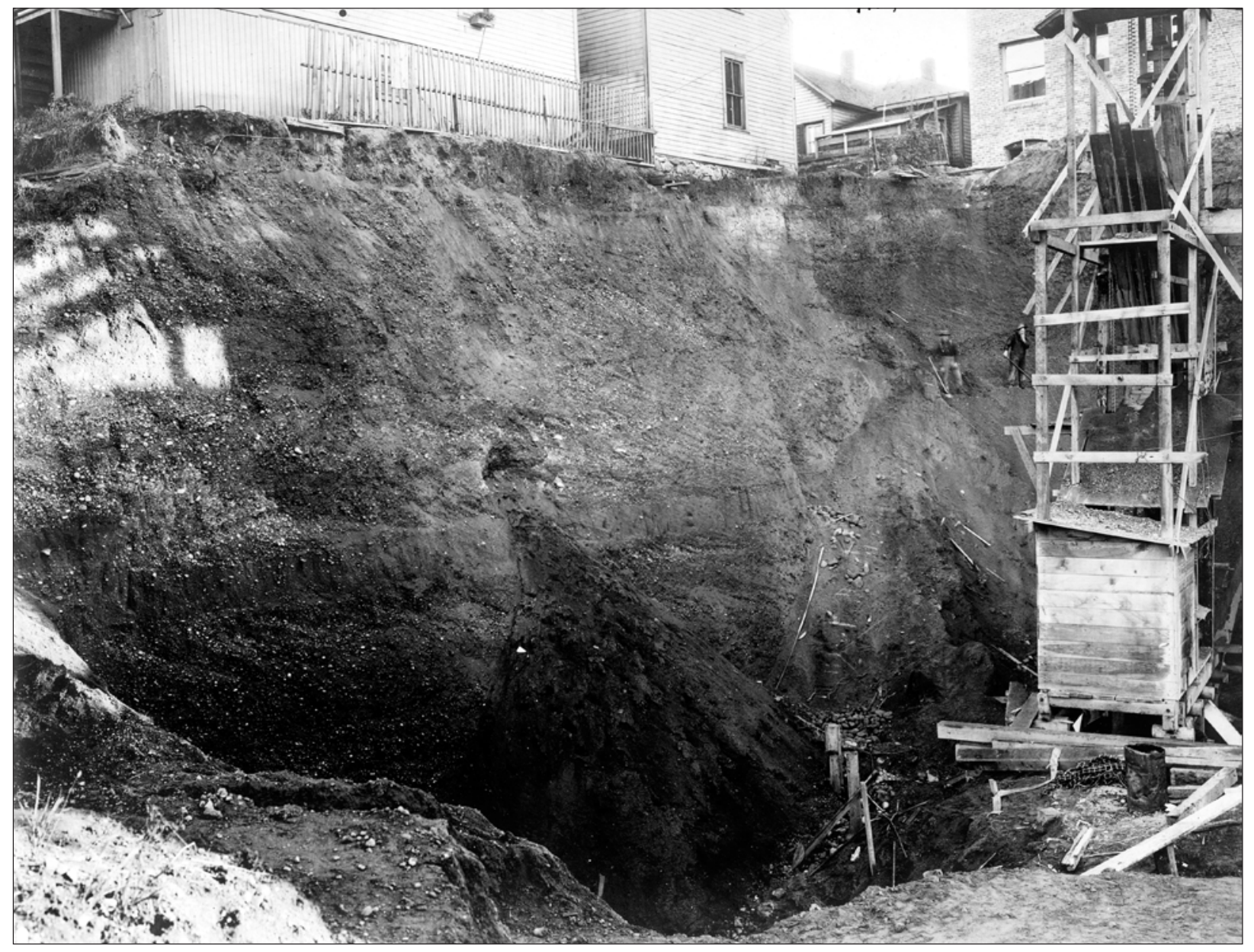

Figure 7. Gravel pit, Summit Avenue near Pine Street, Seattle, Wash., 1907. Photograph by N.H. Darton. Courtesy of USGS Photographic Library. 
national parks, national monuments, and Indian reservations, except where specifically authorized by law (U.S. Bureau of Land Management, 1964). Although the earliest State legislation regulating surface mining was passed in 1939 (in West Virginia), the failure of some States to protect their natural resources eventually led to a large body of Federal, State, and local environmental laws that govern mineral exploration, mine development, and site reclamation.

Mining requires natural science and social science information, environmental studies, and dialogue between the mining company and the local community that allow community concerns to be stated and addressed. Adjacent communities' desired use for the land, societal values (overall quality of life, influenced in part by the mine's visual effect), mitigation of nuisances associated with mining (noise, dust, traffic), laws, and regulatory bodies influence mining operations and treatment of the environment (fig. 8).

State agencies that regulate mining, air quality, and water quality, as well as other agencies such as wildlife and geological surveys and local governments that determine zoning requirements and other infrastructure issues, all might have a role in granting a mining permit. When a company proposes a quarry or mine, contact with local citizen and neighborhood groups is important so that relationships can be built early to resolve problems that may develop. The mining industry is expected to apply the best environmental management standards available and abide by current regulations pertaining to mining and production sites. And in a world where cross-border operations are becoming the norm, international law will play a larger and larger role in the conduct of mining operations.

\section{Regulation Outside the United States}

\section{International Laws and Agreements}

In an increasing global market and industry, governments now tend to focus on an international paradigm of sustainable development and international environmental law (Pring, 2003). Mineral resources are unevenly distributed, and sea trade between industrial countries grows steadily: aggregate has been exported from Scotland to Texas (fig. 9), gypsum from Mexico to California, talc from Montana to Belgium, potash from Saskatchewan to the corn belt of the United States, soda ash from western United States ports to the Pacific Rim, and bentonite from Wyoming to oil rigs all over the world (Kuzvart, 2003).

Mining is increasingly subject to international law but relies on political will for enforcement (United Nations, 2003a). Nevertheless, “*** it [international environmental law] is growing in both scope and enforceability and becoming a force that can no longer be prudently ignored" (Pring, 2003, p. 3). For example, Yellowstone National Park and the Grand Canyon are sites protected in perpetuity and included as part of the world heritage through the 1972 United Nations Educational, Social, and Cultural Organization (UNESCO)
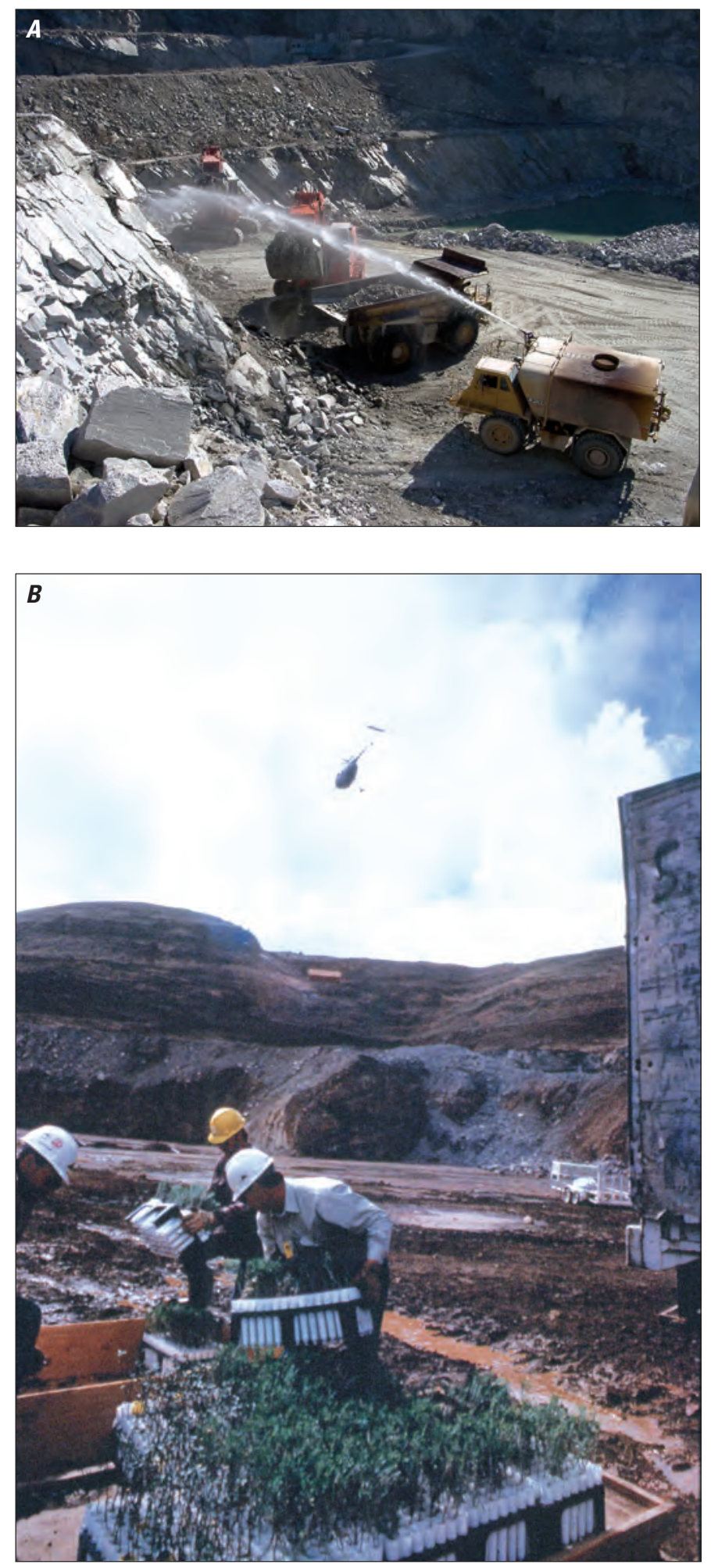

Figure 8. Two dust mitigation methods. $A$, Water sprayed on a rock face during active mining to reduce airborne dust. Courtesy of North Carolina Geological Survey. B, Seedlings airlifted into an active quarry will be planted to begin reclamation of minedout regions of the quarry. Courtesy of Western Mobile Company, Golden, Colo. 


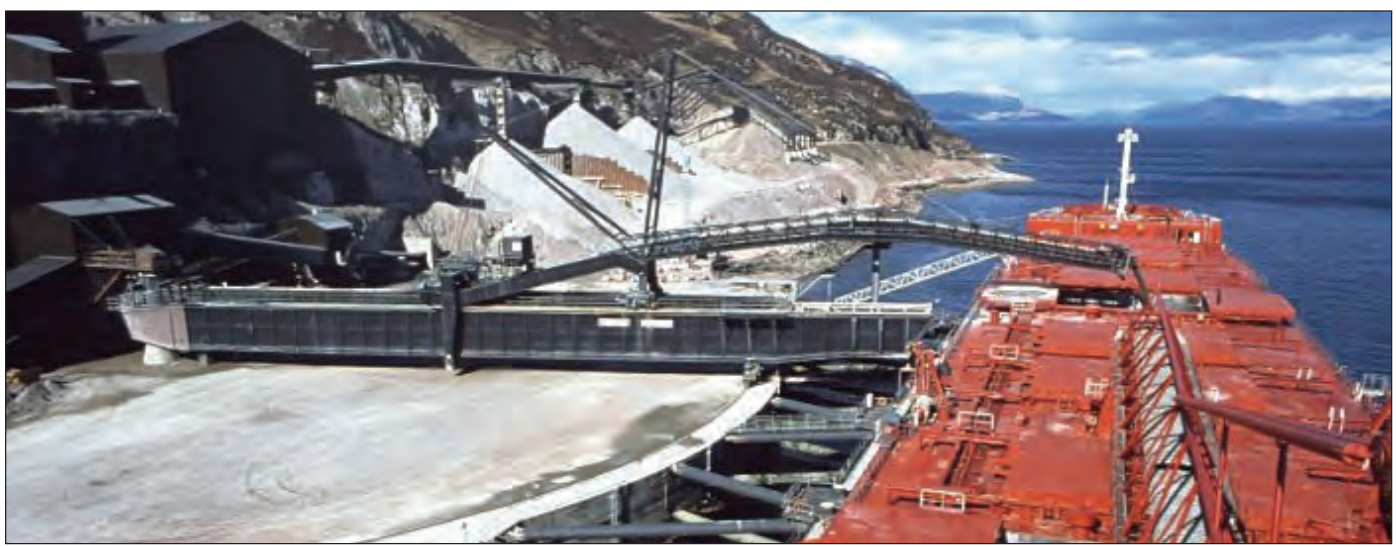

Figure 9. Glensanda coastal granite quarry in Argyll, Scotland. The mining industry serves local, regional, and international markets. Glensanda transports granite only by ship to markets in the United Kingdom and Europe. Image courtesy of Aggregate Industries Yeoman Glensanda.

Convention for the Protection of the World Cultural and Natural Heritage (Pring, 2003). The mining industry has also developed International Organization for Standardization (ISO) 9000 Quality Management System standards and ISO 14000 Environmental System standards to enhance product requirements and minimize harmful environmental effects (Pring, 2003).

International regulatory documents such as treaties and standards treat a broad range of economic, social, and cultural situations affected by the industrial-mineral industry: sustainable development, safety and health, corporate social responsibility, human rights, rights of indigenous peoples, labor rights, public participation, transboundary effects (movement across country borders that results in another action-such as pollution of air or of watershed systems), hazardous substances (for example, mill tailings), land degradation, protection of wild animal species and their habitat, World Heritage sites (as defined by the United Nations), and the marine environment (United Nations, 2003a).

Mineral resources and lands are best managed in a sustainable fashion, just as forest resources are (United Nations, 1992), to meet the social, economic, ecological, cultural, and spiritual needs of present and future generations. These needs include not only mineral products but also shelter and employment.

The Bureau of Land Management and USDA Forest Service have accepted sustainable development of minerals and forests as a foundation for their own public policy (Anderson and others, 2002). The agencies note that principles underlying sustainable development (such as product recycling, social well being, environmental health, and economic prosperity) apply to mining operations (fig. 10). Sustainable development entails the mining industry's use of best practice environmental management to protect biological diversity; sustain ecological processes over the long term; develop sound, scientifically based approaches to land planning; and work with stakeholders to achieve a balance of interests. Sustainable development also "represents an evolution from impact analysis (mitigation of damage) to contribution analysis (ensuring net benefits)" (Chadwick, 2004, p. 2). Sustainability is inherently complex and multifaceted, and it extends beyond site-based issues (Perry, 2004).

\section{Best Management Practices Outside the United States}

Implementing best management practices may be costly, but it produces long-term gains for the industry, the community, and the environment (Environment Australia, 2002). Best-management practices include the following:

- Open and effective communication with the local community and other interested parties

- Adapting risk analysis by taking into account environmental factors, engineering, and planning needs

- Maximizing efficiency (for example, minimizing waste, improving mine design and management practices (Environmental Mining Council of British Columbia, 2004)

- Substituting renewable materials for nonrenewable minerals and recycling

- Adopting best practices even if not required by regulation

- Returning the land to a desirable postmining form

- Applying the Precautionary Principle (“*** the lack of full scientific certainty should not be used as a reason for postponing a measure to prevent degradation of the environment where there are threats of serious or irreversible environmental damage” (Environment Australia, 2002, p. 3). 


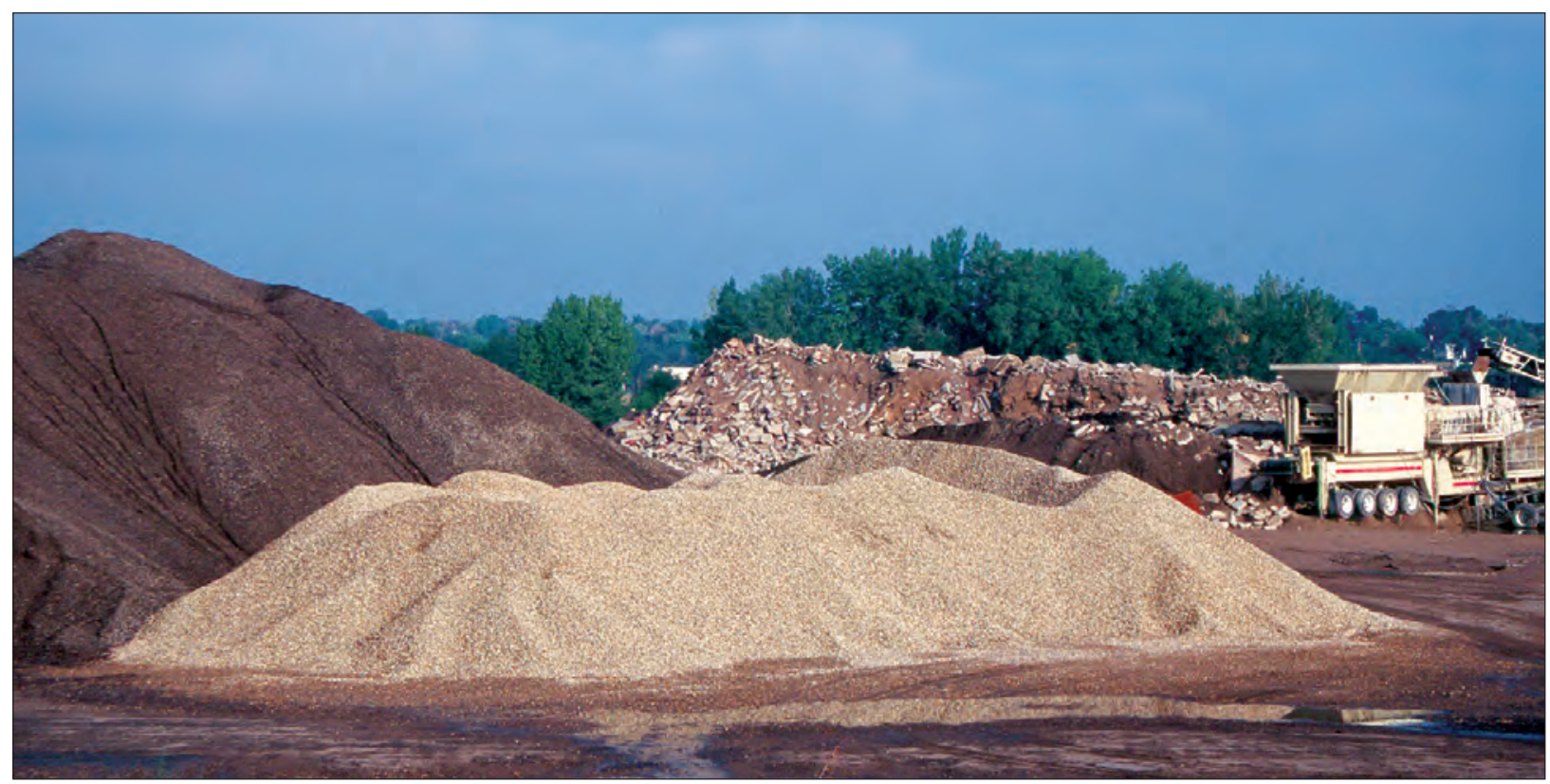

Figure 10. Recycled asphalt and concrete north of Denver, Colo. These materials are available for other projects as part of sustainable construction. Steel pipe, used oil, and scrap tires can also be recycled. Photograph by B. Arbogast, 2002.

The European Union in 2001 agreed that environmental decisionmaking requires the involvement of a community's citizens and responsibility for stewardship of the environment (Meredith, 2004). The question raised is how to ensure fair public participation in an anticipatory rather than reactive mode. Mineral development and reclamation are most successful when mining operators work cooperatively with regulators at all levels, land planners, and the public.

\section{Federal Regulations}

All Federal, State, and private lands in the United States (including USDA Forest Service and BLM lands) are subject to Federal regulations such as the Clean Air, Clean Water, Endangered Species, National Historic Preservation, and National Environmental Policy Acts. Such Federal regulations affect treatment of landscapes and promote public health and safety as well as monetary, physical, aesthetic, and spiritual values (table 2). Environmental policies of the 1990s (such as legislation to protect biodiversity, establish protected habitats, and improve waste management) have not created burdensome economic costs (Organization for Economic Co-operation and Development, 2001). Reclamation costs are minimal if reclamation is planned from the outset (Norman and Lingley, 1992).

The Mining and Minerals Policy Act of 1970 (84 Stat. 1876; 30 U.S.C. 21a) and the National Materials and Minerals Policy Research and Development Act of 1980 encourage the orderly economic development of domestic resources on public lands. The policies assure that the nation's industrial, security, and environmental needs are satisfied while the land's productivity is maintained for other uses and to support biodiversity (USDA Forest Service, 2010a,b).

Minerals as treated under the mining laws are recognized as such when found in public lands in quantity and quality sufficient to render the lands valuable (U.S. Bureau of Land Management, 1964). Potentially valuable minerals on Federal lands are classified according to a "disposition class" as locatable, leasable, or saleable. Mineral disposition classes are broad, and deposits of a given mineral may fall into more than one class depending upon their location, geologic setting, composition, and other factors such as case law. For example, clays and zeolite can be considered locatable, leasable, or saleable. Pumice, depending upon its type, may be considered locatable or saleable (pumicite, volcanic ash, volcanic dust, and scoria) or it may be considered saleable only (for example, volcanic cinders). Gypsum may be considered locatable or leasable (in the form of rock gypsum or anhydrite) or it may be saleable only (if it is gypsite) (U.S. Bureau of Land Management, 1994). The Bureau of Land Management or USDA Forest Service District Office can provide specific information regarding disposition classes that apply to a specific site.

\section{Locatable Minerals}

The term "hard-rock minerals" is widely used as a synonym for "locatable minerals" (National Academy of Sciences, 1999). These minerals are principally the base and precious metal ores (such as copper, lead, zinc, magnesium, molybdenum, nickel, and tungsten, gold, silver, and platinum), ferrous metal ores, and certain classes of industrial minerals: 
Table 2. Typical Federal conservation laws or policies and their implications for certain aspects of mining (modified from Arbogast, 2002).

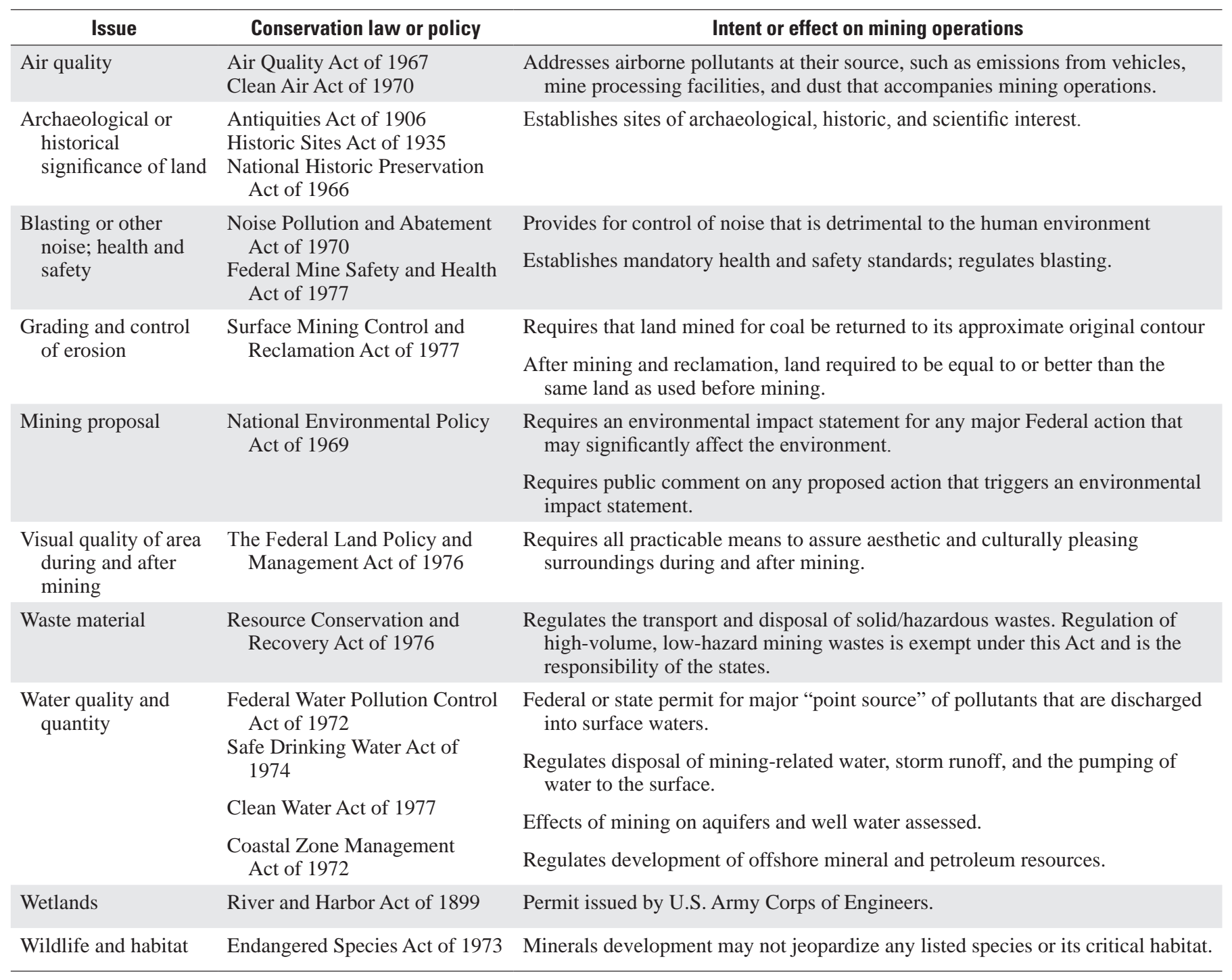

- Nonmetallic minerals such as asbestos, barite, bentonite, borax, cement-grade limestone, ceramic clay, feldspar, fluorspar, gypsum, mica, and zeolite

- Rare earth elements such as uranium or thorium

- Gemstones such as diamonds, sapphires, and rubies

- Industrial stones such as garnet, diamond, and quartz sand. (Although some varieties of garnet may be locatable, common varieties of garnet and other relatively hard minerals used as abrasives may be considered saleable by the USDA Forest Service.)

- Uncommon varieties of sand, gravel, stone, pumice, pumicite, and cinders. (Uncommon varieties of stone are building or decorative stones such as marble, highgrade limestone or dolomite, and some granitic rocks.)
The Multiple Use Mining Act of 1955 (69 Stat. 368, as amended; 30 U.S.C. 611-615) details the classification of locatable minerals (USDA Forest Service, 2010b). Mining of locatable minerals on Federal lands is subject to the General Mining Law of 1872 (17 Stat. 91, as amended; 30 U.S.C. \$22 et seq.) (Nichols, 1999; USDA Forest Service, 2010b). When a valuable mineral deposit is found, a mining claim (a lease that allows the extraction of minerals) may be patented (U.S. Bureau of Land Management, 2004). (A patent gives the successful mining claimant title to both the surface land and to the underlying mineral deposit.) Acquisition is accomplished first by staking the mining claim (marking its surface location, also called "locating") over a deposit and then by acquiring the permits necessary before exploration or mining. The Bureau of Land Management approves any plan of operations that disturbs more than five acres of public land (U.S. Bureau of Land Management, 2004). All mining activities that disturb 
the land surface and that are on USDA Forest Service lands on which a claim may be staked (lands available for "mineral entry") take place in accordance with Title 36 of the Code of Federal Regulations, Part 228-A (Nichols, 1999). Operators carry reclamation bonds to ensure that the site is reclaimed after mining ends (USDA Forest Service, 2010a).

\section{Leasable Minerals}

Leasable minerals may be leased from the Federal government but may not be claimed; that is, the leaseholder may extract the underlying mineral, but the leaseholder does not own the surface land over the mineral deposit. Leasable minerals are as follows:

- Fossil fuels such as coal, oil and gas, oil shale

- Geothermal resources (heat derived from the Earth)

- Nonenergy leasable minerals-Fertilizer and feedstock (for chemical processes) such as phosphate, potassium, and sodium. This category contains chlorides, sulfates, carbonates, borates, silicates, and nitrates of potassium or sodium.

- Native asphalt and solid and semisolid bitumen

- Sulfur on public lands in Louisiana and New Mexico, and silica deposits in certain parts of Nevada (U.S. Bureau of Land Management, 1964).

- Leasable minerals are those commodities that may be acquired on Federal public lands under the Mineral Land Leasing Act of 1920, as amended; the Geothermal Steam Act of 1970, as amended; or the Acquired Lands Act of 1947, as amended (National Academy of Sciences, 1999). The Mineral Leasing Act of 1920 gives authority to the USDA Forest Service to manage leasable minerals on national forest system lands (USDA Forest Service, 2010b).

On USDA Forest Service lands, oil, gas, and fertilizer resources are managed in three stages: leasing, exploration, and development. Land must go through a competitive bid, held by the Bureau of Land Management, for a lease to be obtained (USDA Forest Service, 2010a). "Leases are issued for specific periods of time, and the lessee pays a rental fee and royalties on the minerals produced. $* * *$ After public lands are leased, applications to conduct exploration, drilling, and productionrelated activities are reviewed to ensure technical competence, environmental protection, and mineral resources conservation" (U.S. Bureau of Land Management, 2004).

\section{Saleable Minerals}

Saleable minerals are the common varieties of construction materials and aggregates, such as sand, gravel, and cinders and roadbed and ballast material. Common-variety minerals do not possess any special quality, quantity, character, or location that makes them of unique commercial value (National Academy of Sciences, 1999). Saleable minerals may also be common varieties of pumice, pumicite, and ordinary clay. These minerals may be obtained under the Mineral Materials Act of 1947, as amended (30 U.S.C. 602-604, 611-615) (National Academy of Sciences, 1999).

"Common landscaping and construction materials $* * *$ are available through material sales at fair market value or through free use permits and government agencies and nonprofit organizations" (U.S. Bureau of Land Management, 2004). Free use permits are no-fee permits with special provisions; for example, the resource obtained may not be sold or exported from the State. Small tonnages that can be easily removed are sold over the counter through a noncompetitive process. Larger tonnages or the contents of known deposits of common-variety minerals may be sold either competitively or noncompetitively (Nichols, 1999). In a competitive sale, the material bid on goes to the highest bidder. The operator posts reclamation bonds to ensure site reclamation (USDA Forest Service, 2010a).

Various instances of case law and mineral estates (which have a distinct set of legal rights pertaining to owning land with mineral rights) can change the administrative regulations for these commodities. The appropriate Bureau of Land Management or USDA Forest Service field office can provide more detailed and up-to-date information regarding Federal regulations and definitions.

In the Rocky Mountain region, the USDA Forest Service's Mineral Materials Program is ranked as the tenth largest producer of saleable minerals (primarily aggregate) in the United States (USDA Forest Service, 2010a). Saleable mineral materials mined on public lands in Colorado are mainly sand and gravel for concrete aggregate and fill, and rock for aggregate, riprap, and decorative purposes (flagstone and moss rock) (U.S. Bureau of Land Management, 2009).

\section{Mineral Specimens Sought by Collectors}

Rock hounding and collecting mineral specimens (activities such as gold panning or digging out a few quartz crystals) are considered to be hobbies or personal activities if they involve only the occasional removal of small amounts of material by hand from surface exposures (Nichols, 1999).

"Rocks, mineral specimens and semi-precious gemstones, petrified wood, $* * *$ may be collected on public lands without charge or permit in reasonable amounts [see reference cited for definitions] as long as the specimens are for personal use and are not collected for sale or barter to commercial dealers. Collectors should note that there are some restrictions [including prohibited areas and locations encumbered with un-patented mining claims] and a BLM permit may be required, depending on the amount of material you collect, how you collect it, where or when you collect, and whether the material 
will be used commercially. $* * *$ [Approved] Collection and removal cannot be aided with motorized or mechanized equipment including but not limited to: tractors, bulldozers, plows, power shovels, semitrailers or other heavy equipment is not authorized. Undue or unnecessary degradation of the public lands is not allowed during the removal of rocks, minerals, gemstones, or fossils” (U.S. Bureau of Land Management, 2009).

\section{USDA Forest Service and Bureau of Land Management Regulations}

The USDA Forest Service manages the land surface in national forests. The Bureau of Land Management, as the "keeper of the mineral estate," regulates subsurface mining on both Bureau of Land Management and USDA Forest Service lands. The Bureau also sets national policies and processes for extraction of solid minerals (that is, nonpetroleum resources) under Federal jurisdiction: coal and nonleasable minerals, hard-rock minerals on acquired lands, locatable minerals, and saleable minerals. In addition, it is the custodian of publiclands records for the United States Government (U.S. Bureau of Land Management, 1997).

USDA Forest Service and Bureau of Land Management regulations provide procedures for the exploration, development, and disposal of mineral resources from national forests and other public lands. In order to understand information regarding mining on national forest lands, one must first understand terms that describe mineral-estate status (Nichols, 1999).

Applications for prospecting permits and leases are required for hard-rock minerals on "acquired status" forest lands. Acquired status refers to national forest lands and minerals purchased, donated, or received in exchange for purchased or donated lands and minerals.

- "Public domain" status refers to land and minerals withdrawn or reserved for use as part of national forests or national grasslands; those lands have never left Federal ownership or been received in exchange for land of the same status. Mining claims for locatable minerals can be sited only on public-domain-status forest lands. In all cases, a reclamation bond sufficient to insure full site reclamation is required to be submitted by the operator.

- Not all Bureau of Land Management and USDA Forest Service lands are available for mineral prospecting and mining. Various categories of these lands have been withdrawn to meet other public purposes. Chief among these withdrawn lands are congressionally designated wilderness areas (National Academy of Sciences, 1999); others are national parks, national monuments, Indian reservations, most reclamation projects, military reservations, scientific testing areas, and lands designated for the National Wilderness Preservation System or the Wild and Scenic Rivers System (U.S. Bureau of Land Management, 1996) (fig. 11). Other exempt lands are national forest system lands, those currently staked by a mining claim, or Bankhead-Jones lands, principally national grasslands. (The Bankhead-Jones Farm Tenant Act of 1937 authorized the Federal government to acquire damaged farm lands in order to rehabilitate and use them for various purposes (U.S. Senate, 2003)). The Act also allows limited discretion for disposal of mineral materials on land acquired under this act provided development does not interfere with the primary purpose of the land (USDA Forest Service, 2010b).

Regulations specifically allow mining, but they also protect the mineable resource and the environment. The authority for these regulations for both agencies is the Materials Act of July 31, 1947, as amended. USDA Forest Service regulations are found in 36 CFR Subpart C entitled "Disposal of Mineral Materials" and the Bureau of Land Management regulations are located in 43 CFR Part 3600 entitled "Mineral Materials Disposal.” The Resources Planning Act of 1974, the National Forest Management Act of 1976, the Federal Land Policy and Management Act of 1976, and the Public Rangelands Improvement Act of 1978 give the USDA Forest Service and Bureau of Land Management specific planning and management responsibilities. Both agencies are to balance public values of outdoor recreation and open space with traditional uses such as timber harvesting, mining,

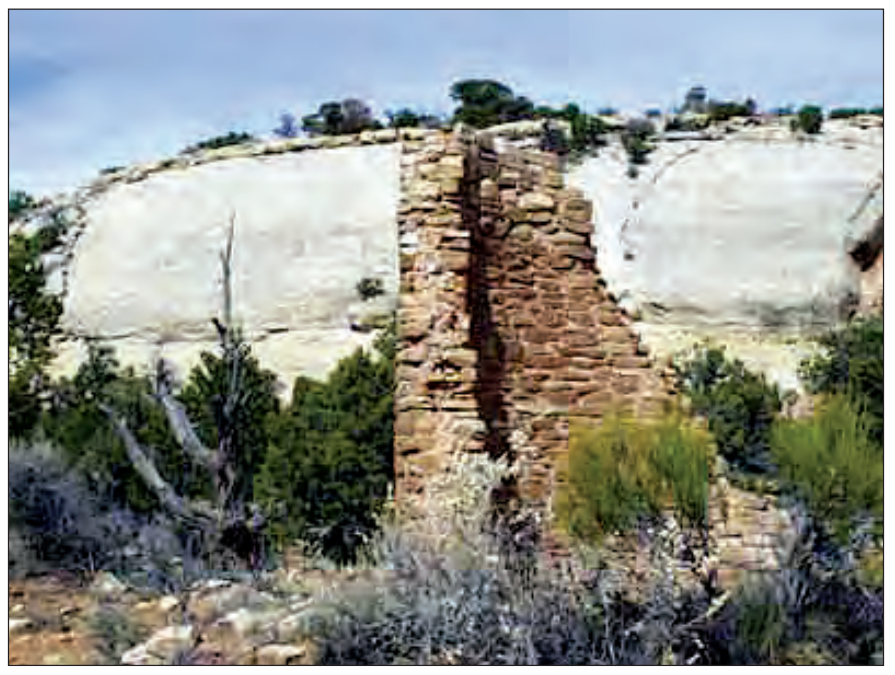

Figure 11. A 13th century Puebloan structure in the Canyons of the Ancients National Monument, southwest Colorado. Activity on two existing mining claims in the national monument will be regulated in order to protect the purpose of the monument, and no new claims will be permitted. Photograph courtesy of Bureau of Land Management. 
or livestock grazing. Decisions on conflicting uses are made on a case-by-case basis.

The Materials Act of July 31, 1947, as amended, defines mineral materials such as petrified wood and common varieties of sand, stone, pumice, pumicite, cinders, clay, and similar materials. USDA Forest Service regulations have further defined the deposits that are used for agriculture, animal husbandry, building, abrasion, construction, and landscaping. The policy of both agencies is to (1) sell the mineral material resources at not less than fair market value, (2) permit Federal, State, and local government entities and nonprofit organizations free use for qualified purposes, (3) protect both the mineral resources and the environment and minimize damage during mining, (4) prevent unauthorized removal of mineral materials, and (5) require purchasers and permittees to be accountable for their actions.

Resources deemed to be a mineral material can be acquired through a special-use permit or mineral-materials contract through the USDA Forest Service or Bureau of Land Management. The permits or contracts themselves can be obtained by competitive sales, negotiated contracts, preference-right negotiated sale, or free-use and agency-force account. Each method will have volume and acreage limitations. The length of contract may not exceed one year unless an extension is authorized.

All mining operations are governed by an approved Operating Plan (USDA Forest Service) or Mining and Reclamation Plan (Bureau of Land Management). These documents state (1) who will direct the mining operation, (2) how the resource will be mined, (3) when mining will occur, (4) where the quarry is to be located and how it will be accessed, and (5) how the site will be reclaimed either during mining or when the project is completed. Any proposed structures or building occupancy on the site is required to be described on the plan. A map of the proposed mine area and location of the resource and access roads to it is required to be attached to the plan. An environmental assessment is conducted for the proposal.

An authorized officer completes the award of a contract. The award depends on the submittal of an acceptable bid, the ability to perform in a timely fashion, and receipt of an approved bond. The authorized officer ensures that an environmental analysis is completed for all planned mining.

The bond is required to be sufficient to assure payment (rent on the lease and royalties on the material extracted) and timely reclamation of the mining site. Moreover, regular inspections are required of all stockpiles of mined material. Production records are used to determine volumes removed and verify the correct payments - and they may serve as a deterrent to theft of stockpiled material. Acceptable bond forms are outlined in agency manuals.

Poor administration or inattentiveness by the parties can result in theft of mineral materials. Regular inspections are required of all mineral material resource disposals. Production records are necessary to determine volumes removed and verify the correct payment for the resource.

\section{State Regulations}

State law does not take precedence over Federal law, and States differ greatly in their regulations regarding mine reclamation and in their definitions of a mineral. A minerals agreement is a contract between lessor and lessee that states the right to explore for specified minerals and the obligation to develop or to produce (or both) those minerals during a specified length of time. States require a minerals agreement if Federal lands or Indian Tribal lands within the State are to be mined, and the mining company must comply with the terms of State, county, and municipal approvals and permits. In addition, State regulations and policies that govern mine reclamation may address the following topics:

- Public comment-Required during the development of new regulations, review of permits, and release of bonds after reclamation, and when citizen complaints are presented

- Financial assurances-Permit fees, fines, penalties, and performance bond

- Pre-mining environmental data-Hydrology, geology, plant coverage, air and water quality, wetlands, land use or zoning, historic value

- Mining and reclamation standards-Topsoil (its salvage, maintenance, and redistribution), grading and stabilization of slopes, soil analysis, revegetation (density, species richness, use of native species), fugitive dust, noise, protection of surface water and groundwater, wildlife habitat, visual screening, disposal of waste (including mill tailings), drainage from the mined area (surface runoff, construction of diversion structures) (table 3).

State agencies involved in regulating the industry may be concerned with public health, public safety, natural resources, wildlife, engineering practices, transportation, labor, historical preservation, and revenue. These agencies ensure compliance with State and Federal standards governing water and air quality and with regulations concerning archeological or historical sites. Historical cultural landscapes may include farms, ranch lands, mining districts, transportation corridors, irrigation systems, parks, and prehistoric sites (Colorado Historical Society Office of Archaeology and Historic Preservation, 2001) (fig. 12). More than 100 mining-related properties are listed in the Colorado State Register of Historic Properties (Colorado Historical Society Office of Archaeology and Historic Preservation, 2003). The National Register of Historic Places (U.S. Department of the Interior National Park Service, 2004) lists a number of mining districts in Colorado that are administered by the National Park Service: for example, Lake City (in the heart of the San Juan Mountains of south-central Colorado), Littlejohn mine complex (near Granite), Vicksburg and Winfield 
Table 3. Typical State policies and their implications for certain aspects of mining.

\begin{tabular}{|c|c|}
\hline Aspect & Requirement of state policy \\
\hline Air quality & Compliance with State and Federal regulations. \\
\hline Archaeological or historical significance of a site & Compliance with State and Federal regulations. \\
\hline \multirow[t]{2}{*}{ Grading or control of erosion } & $\begin{array}{l}\text { Final topography (slope angle and shape, drainage) appropriate for proposed land use } \\
\text { after mining and similar to surrounding landforms. Affected land protected from } \\
\text { slides; surface areas stabilized; specified ratios for lakes or pond slopes. }\end{array}$ \\
\hline & Seeding, mulches, and careful location of drainage and water-control systems. \\
\hline Overburden and backfill & $\begin{array}{l}\text { Map of general type, thickness, and distribution of soil. Topsoil preserved and } \\
\text { segregated from spoil. }\end{array}$ \\
\hline Site location & $\begin{array}{l}\text { Permit or minerals agreement required, as are maps and cross sections of site. } \\
\text { Impermeable pit floors may need to be blasted so that water can drain from the site. } \\
\text { Water sources may be included in the design of a post-mining pond or wetland. }\end{array}$ \\
\hline Vegetation & $\begin{array}{l}\text { Premining inventory of vegetation. Plan for post-mining vegetation (a diverse, } \\
\text { effective, and long-lasting vegetative cover capable of self-regeneration and at } \\
\text { least the equivalent of cover in the surrounding area). Specification and location of } \\
\text { ground cover and trees to be planted. Irrigation schedule if necessary. }\end{array}$ \\
\hline Water quality and quantity & $\begin{array}{l}\text { Compliance with Federal, State, and county regulations. Map of existing water- } \\
\text { courses, streams, rivers, ponds and wetlands. Covers nonpoint-source pollution, } \\
\text { water rights. Hydraulic project approval, drainage controls. }\end{array}$ \\
\hline Wetlands & Stream channel reconstruction. Federal dredge-and-fill permit. \\
\hline Wildlife & $\begin{array}{l}\text { Compliance with Federal and State regulations. Wildlife on site protected; diverse } \\
\text { habitat encouraged; endangered species protected. }\end{array}$ \\
\hline
\end{tabular}

mining camps (northwest of Buena Vista), Crystal mill (southeast of Marble), Ore Processing mill and dam (Georgetown), and the Argo tunnel and mill (Idaho Springs). (Some of these historic places are also on national forest lands: the Littlejohn mine complex, the Vicksburg and Winfield mining camps, and the Crystal mill.) The Mineral Belt Trail around the outskirts of Leadville winds through the mining district, historic structures, and mining artifacts.

Beyond required Federal regulations that are enforced at the State level, States differ in which particular minerals or aspects of mining are regulated and to what extent.
Generally, State laws are directed at problems most pressing in that State (Toy and Hadley, 1987). For example, in Colorado the ponding of water and its subsequent evaporation led to a court ruling: mine operators that expose groundwater to the atmosphere must obtain a permit from the State Engineer to do so, and the operator must make up for injurious evaporation losses through a plan to replenish the lost groundwater (Brown, 1989).

All mining and reclamation in Colorado is directed by the Colorado Mined Land Reclamation Board. The Board oversees the Division of Minerals and Geology, which issues mining and 

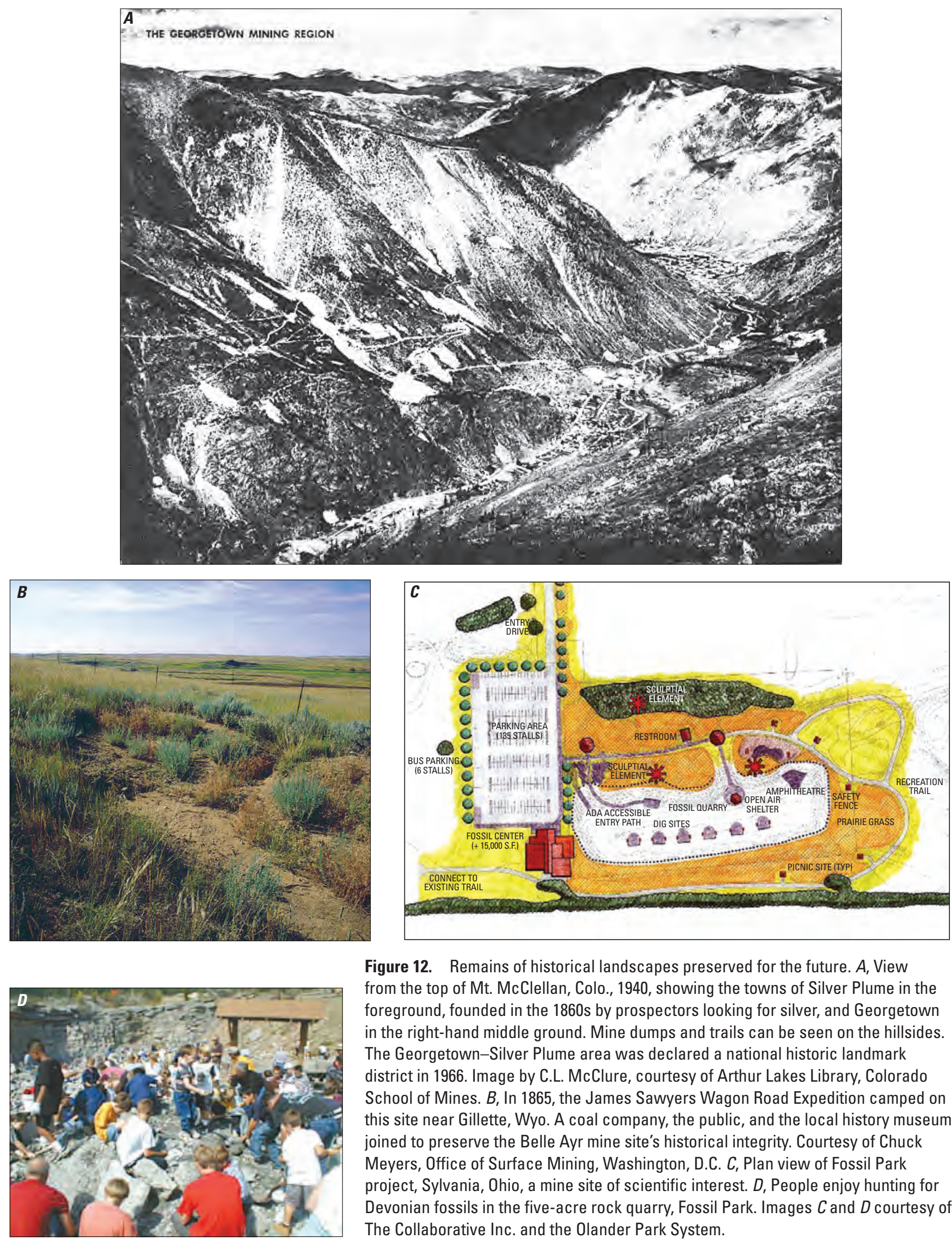

Figure 12. Remains of historical landscapes preserved for the future. $A$, View from the top of Mt. McClellan, Colo., 1940, showing the towns of Silver Plume in the foreground, founded in the 1860s by prospectors looking for silver, and Georgetown in the right-hand middle ground. Mine dumps and trails can be seen on the hillsides. The Georgetown-Silver Plume area was declared a national historic landmark district in 1966. Image by C.L. McClure, courtesy of Arthur Lakes Library, Colorado School of Mines. $B$, In 1865, the James Sawyers Wagon Road Expedition camped on this site near Gillette, Wyo. A coal company, the public, and the local history museum joined to preserve the Belle Ayr mine site's historical integrity. Courtesy of Chuck Meyers, Office of Surface Mining, Washington, D.C. C, Plan view of Fossil Park project, Sylvania, Ohio, a mine site of scientific interest. $D$, People enjoy hunting for Devonian fossils in the five-acre rock quarry, Fossil Park. Images $C$ and $D$ courtesy of The Collaborative Inc. and the Olander Park System. 
reclamation permits, within the Colorado Department of Natural Resources. The Minerals Program of the Office of Mined Land Reclamation (a part of the Colorado Division of Minerals and Geology) reviews mine permit applications; it is funded largely through permit fees paid by mine operators.

Before mining operations begin, the State of Colorado requires three items:

- A performance bond-A promise that the mining operation will reclaim the land; it gives the State the authority to pursue reclamation costs from operations that fail to reclaim

- A reclamation bond-A financial warranty that equals the cost the State would incur to reclaim the site should the mining operation fail to reclaim the site

- A permit-With minor exceptions, all mine operators must obtain a State permit for extraction of minerals and disturbance of soils (U.S. Environmental Protection Agency, 1995a). Exceptions are made for extraction where material is not sold or hauled offsite, foundation excavation with an approved building permit, or excavation for tunnels that will carry water or roads.

- Copies of Colorado's laws and regulations are located in the Colorado Revised Statutes at certain public libraries (called government repository libraries); they are also available for a small fee from the Division of Minerals and Geology (Department of Natural Resources, 1313 Sherman Street, Denver, Colo., 80203).

\section{Municipal and County Regulations}

Through land-use regulations and zoning, local governments (municipalities, counties, special districts, and regional authorities) usually have the greatest control over how land is used. Such regulations and laws commonly are carefully evaluated at the time a mine site is selected. Restrictive zoning requirements in some jurisdictions may prohibit any industrial activity. Local agencies may determine the land use, both before and after a mining application is submitted, and establish additional regulations to protect the environment (commonly, limits on noise and on traffic and requirements controlling aesthetics - the visual appearance of the mine site). Municipalities that include citizens in the decisionmaking process, zoning changes, mine permitting, and environmental impact studies give the public a way to influence where mine operations are sited.

Municipal or county zoning powers have been used in three ways to allow mining (Werth, 1993). First, special extraction districts can be created; mining is then considered the highest and best use of land in the district. Second, areas underlain by mineral resources can be shown as an overlay on a zoning map; the jurisdiction then determines where mining will create the least conflict. Third, mineral deposits are mapped into existing use districts (such as agriculture, open space, or industrial; mining is allowed as a special exception).

Applicants for mining in Colorado are required to notify the local county government, municipalities within 2 miles, and all landowners within 200 feet (ft) of the mine's affected land, and they publish a weekly notice in a local newspaper for two weeks before an application hearing. Colorado counties differ in their approaches to mineral development. Boulder County Land Use Department (2008) prepared a comprehensive plan that contains a mineral resource areas map and geologic hazards and constraint areas map. Mineral resource areas do not overlap lands defined and mapped as critical wildlife habitat, agricultural lands of national or statewide importance, or designated natural landmarks and natural areas. Clear Creek County created a special extraction district and paired it with an ordinance considering mining the highest and best use of land in that district. The Jefferson County Mineral Extraction Policy Plan (Jefferson County, Colorado, Planning and Zoning, 1977) established a point system for evaluating mine sites according to their ability to conform to county goals. Table 4 lists potential mining issues and how they may be addressed from a local perspective.

\section{Production of Industrial Minerals}

\section{Overview}

In 2003, Colorado produced $\$ 672$ million worth of nonfuel minerals, principally construction sand and gravel, Portland cement, molybdenum concentrates, gold, and crushed stone (U.S. Geological Survey, 2004). Colorado possesses numerous deposits of several essential industrial minerals, such as sand and gravel, stone, nahcolite (used to manufacture sodium bicarbonate or baking soda), gypsum, and limestone. The Colorado mineral belt, an elongate zone containing high concentrations of metallic minerals, extends from Boulder in the northeast diagonally across the State to the San Juan Mountains in Colorado's southwestern corner. Many of these mineral deposits are located in or near national forests and national grasslands (see fig. 5).

National forests in the western United States come in all sizes, shapes, climates, environments, and geologic settings. Although few forests are underlain by base or precious metal deposits or energy resources, nearly all forests are underlain by at least one industrial mineral (table 5). Even though industrial minerals have never been (or no longer are) produced in some forests, changes in technology or in economic or political views could encourage development of these resources. Consequently, if the stewards of our national forests understand the potential industrial mineral resources in their jurisdictions, then they can effectively evaluate proposed mineral development and manage any development in an informed manner. 
Table 4. Typical county or municipal policies and their implications for certain aspects of mining.

\begin{tabular}{|c|c|}
\hline Aspect & Requirements of county and municipal policy \\
\hline Air and water quality & $\begin{array}{l}\text { Preservation and conservation of groundwater and air quality; meet and maintain } \\
\text { state and county water and air quality standards. }\end{array}$ \\
\hline Blasting or other noise; health and safety & $\begin{array}{l}\text { Noise impact criteria, noise and blasting study, fire protection study, radiation } \\
\text { study, safety fencing. Buffer zones and reclamation setbacks. Hours of operation } \\
\text { regulated. }\end{array}$ \\
\hline Geologic hazards & Geologic report. \\
\hline Grading, control of erosion & Restrictions on post-mining uses and grading plans for final land contours. \\
\hline Mineral transportation & $\begin{array}{l}\text { Site access map, traffic impact study, road access requirements, hours of operation } \\
\text { limited. Detouring, paving, and speed control may be included. }\end{array}$ \\
\hline Mining proposal & $\begin{array}{l}\text { Mining permit, reclamation plan, environmental impact statement, and public } \\
\text { notice. }\end{array}$ \\
\hline Vegetation & $\begin{array}{l}\text { Vegetation study, soil report, revegetation plan, specifications for landscaping. } \\
\text { Topsoil retained. }\end{array}$ \\
\hline Visual quality & $\begin{array}{l}\text { Protect and preserve natural landmarks, visual impact study (visibility mapping } \\
\text { and visualization techniques), and open-space-resources study, screening } \\
\text { requirements. Create slopes that fit in with surrounding landforms. }\end{array}$ \\
\hline Waste material & On-site sewage disposal. \\
\hline Wetlands & Wetland conservation, tie into natural drainage. \\
\hline Wildlife & Wildlife study, wildlife impact report, conservation of critical habitats. \\
\hline
\end{tabular}

Mining of industrial minerals may be as simple as using a front-end loader to excavate a gravel deposit or as complex as the meticulously planned blasting and processing techniques required to liberate tungsten or molybdenum ore (fig. 13A). Extraction may occur in open pits or quarries; along streambeds, valley bottoms, or river terraces; under lakes or in underground mines. All forms of mining entail dust, noise, traffic, erosion, changes to landscapes, and displacement of flora and wildlife. These considerations are discussed in more detail later.

Processing may use mechanical operations, termed beneficiation, that separate the desired mineral from waste rock (fig. 13B). For example, beneficiation may sequentially use crushing, grinding, washing, screening, pulverizing, sizing, and magnetic or centrifugal separation (or both). The extraction of some minerals may require further processing, such as physical separation according to specific gravity; chemical separations such as leaching with acids, bases, or oxides; electrolysis; or distillation. Some treatments, such as heating, take place in both the beneficiation and manufacturing stages. Some very fine grained material (such as mine tailings) is commonly considered waste. The tailings may need to be dewatered and revegetated as part of mine operations. Treatments range from passive drying in surface tailings ponds to highly technological methods that produce high-density slurry and paste backfills. Increasingly, waste material is being reused as raw material for some other product. For instance, cement or concrete projects may use recycled granular mine tailings and recovered mineral components (such as those in coal fly ash, the residue from coal combustion), thereby preventing waste and saving energy.

The estimated value of minerals changes with time owing to the economy (which in turn depends on consumer confidence, retail sales, industrial production, home starts, and inflation), regulations and trade agreements, technological improvements, research to reduce production costs, and new uses for byproducts (U.S. Geological Survey, 2004). Transporting the material from the mine to a point of use or sale is often the most costly phase of the resource supply line. Deposits of natural aggregates (rock materials in their natural state, such as sand and gravel, in contrast to artificial aggregate such as slag or expanded clay) near large population centers, such as Denver, have a high economic value. Such construction materials are usually readily available in large quantities and, therefore, have low unit value- - the cost of a ton or truckload of the material is relatively small.

Other industrial minerals are less common than sand and gravel or building stone and have more technical industrial applications (table 6). Because of their relative scarcity, some industrial minerals have a higher economic unit value than 
Table 5. Principal industrial minerals of Colorado, their uses and source areas (modified from Keller and Widmann, 2002; Mineral Information Institute, 2004).

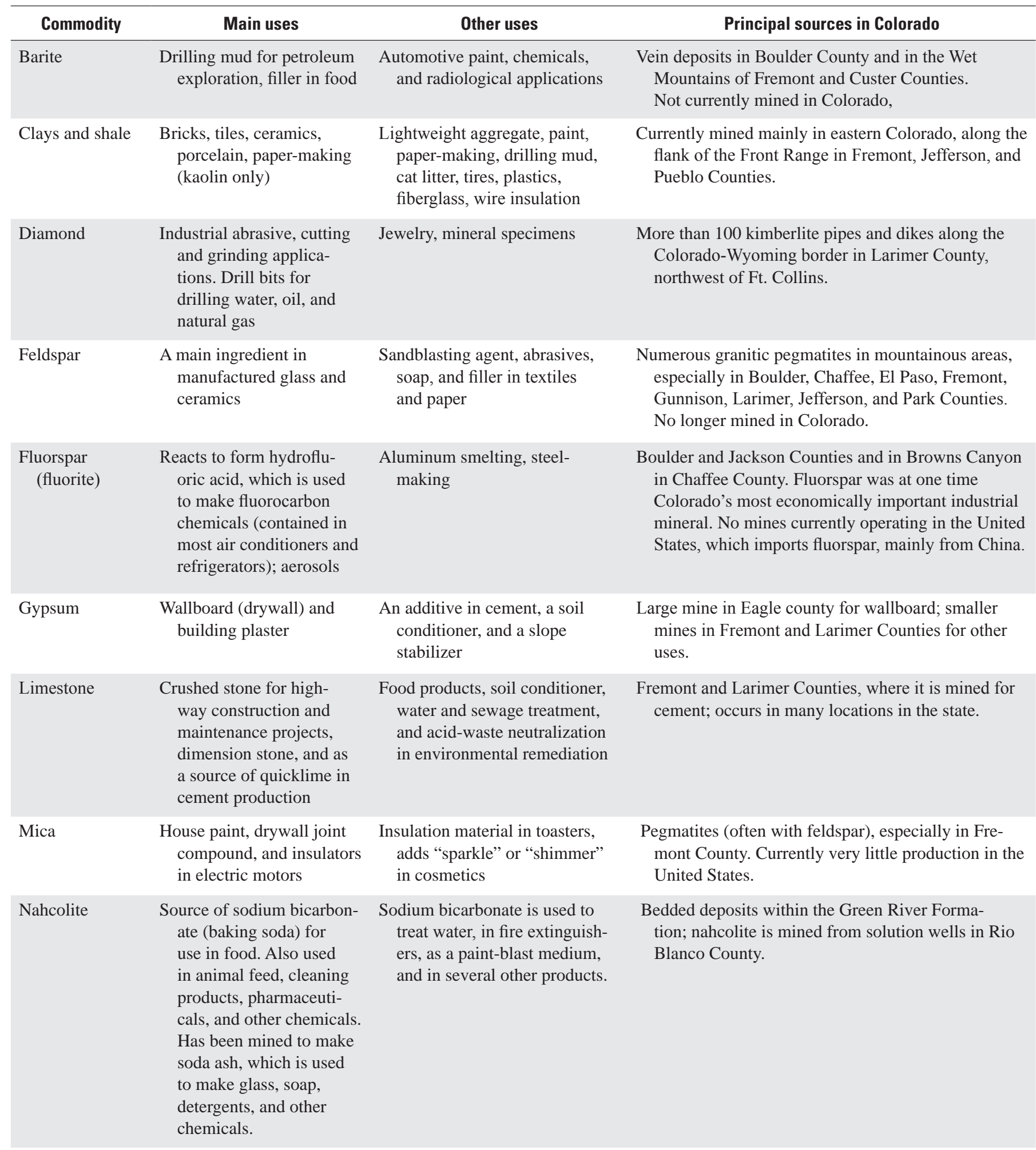


Table 5. Principal industrial minerals of Colorado, their uses and source areas (modified from Keller and Widmann, 2002; Mineral Information Institute, 2004).-Continued

\begin{tabular}{|c|c|c|c|}
\hline Commodity & Main uses & Other uses & Principal sources in Colorado \\
\hline $\begin{array}{l}\text { Sand \& gravel } \\
\quad \text { (construction) }\end{array}$ & $\begin{array}{l}\text { Construction aggregate } \\
\text { (concrete and asphalt), } \\
\text { road base and fill }\end{array}$ & $\begin{array}{l}\text { Golf course sand traps, trout- } \\
\text { spawning habitat for } \\
\text { hatcheries }\end{array}$ & $\begin{array}{l}\text { All areas of the state along rivers and major creeks } \\
\text { and in former glacial valleys. }\end{array}$ \\
\hline $\begin{array}{l}\text { Stone } \\
\text { crushed) }\end{array}$ & $\begin{array}{l}\text { Construction aggregate } \\
\text { (concrete and asphalt), } \\
\text { road base and fill }\end{array}$ & $\begin{array}{l}\text { Barbecue grill rock (volcanic } \\
\text { cinder), decorative stone for } \\
\text { landscaping }\end{array}$ & $\begin{array}{l}\text { Granite and metamorphic rock in the Front Range and } \\
\text { other mountains; volcanic rock in southwest and } \\
\text { south-central Colorado; limestone, sandstone, and } \\
\text { quartzite in eastern Colorado; marble in Chaffee } \\
\text { County; volcanic cinder in Costilla and Eagle } \\
\text { Counties. }\end{array}$ \\
\hline Titanium & $\begin{array}{l}\text { Used in its oxidized form as } \\
\text { white pigment in paints, } \\
\text { plastics, and paper }\end{array}$ & $\begin{array}{l}\text { Titanium metal is used in jet } \\
\text { engines and airplane frames, } \\
\text { very light bicycle frames, and } \\
\text { golf clubs }\end{array}$ & $\begin{array}{l}\text { Large potential resources in southern Gunnison } \\
\text { County and on the eastern plains near Limon, } \\
\text { in Elbert County. No mines currently operate. }\end{array}$ \\
\hline Vermiculite & $\begin{array}{l}\text { Similar to perlite, useful } \\
\text { when greatly expanded } \\
\text { by heat; used as fire- } \\
\text { proof insulation material } \\
\text { and as a soil conditioner }\end{array}$ & $\begin{array}{l}\text { Protective base material for } \\
\text { swimming pools }\end{array}$ & $\begin{array}{l}\text { Only in Precambrian and Cambrian rocks in the } \\
\text { mountains of Colorado. Best deposits in Chaffee, } \\
\text { Custer, Fremont, Gunnison, Jackson, and Pueblo } \\
\text { Counties. Not presently mined in the state. }\end{array}$ \\
\hline $\begin{array}{l}\text { Zeolites } \\
\text { (clinoptilolite } \\
\text { and other } \\
\text { minerals) }\end{array}$ & $\begin{array}{l}\text { Because of its capacity for } \\
\text { cation-exchange, used in } \\
\text { water treatment plants. } \\
\text { Removes ammonia, } \\
\text { arsenic, radon, and other } \\
\text { impurities }\end{array}$ & $\begin{array}{l}\text { Used in pet litter to remove odor } \\
\text { and in nuclear plant effluent to } \\
\text { remove radioactive ions }\end{array}$ & $\begin{array}{l}\text { In the past, clinoptilolite occurred in Moffat County } \\
\text { in Tertiary alkaline lake-bed deposits; it was mined } \\
\text { from an altered volcanic ash layer near Creede in } \\
\text { Mineral County. }\end{array}$ \\
\hline
\end{tabular}



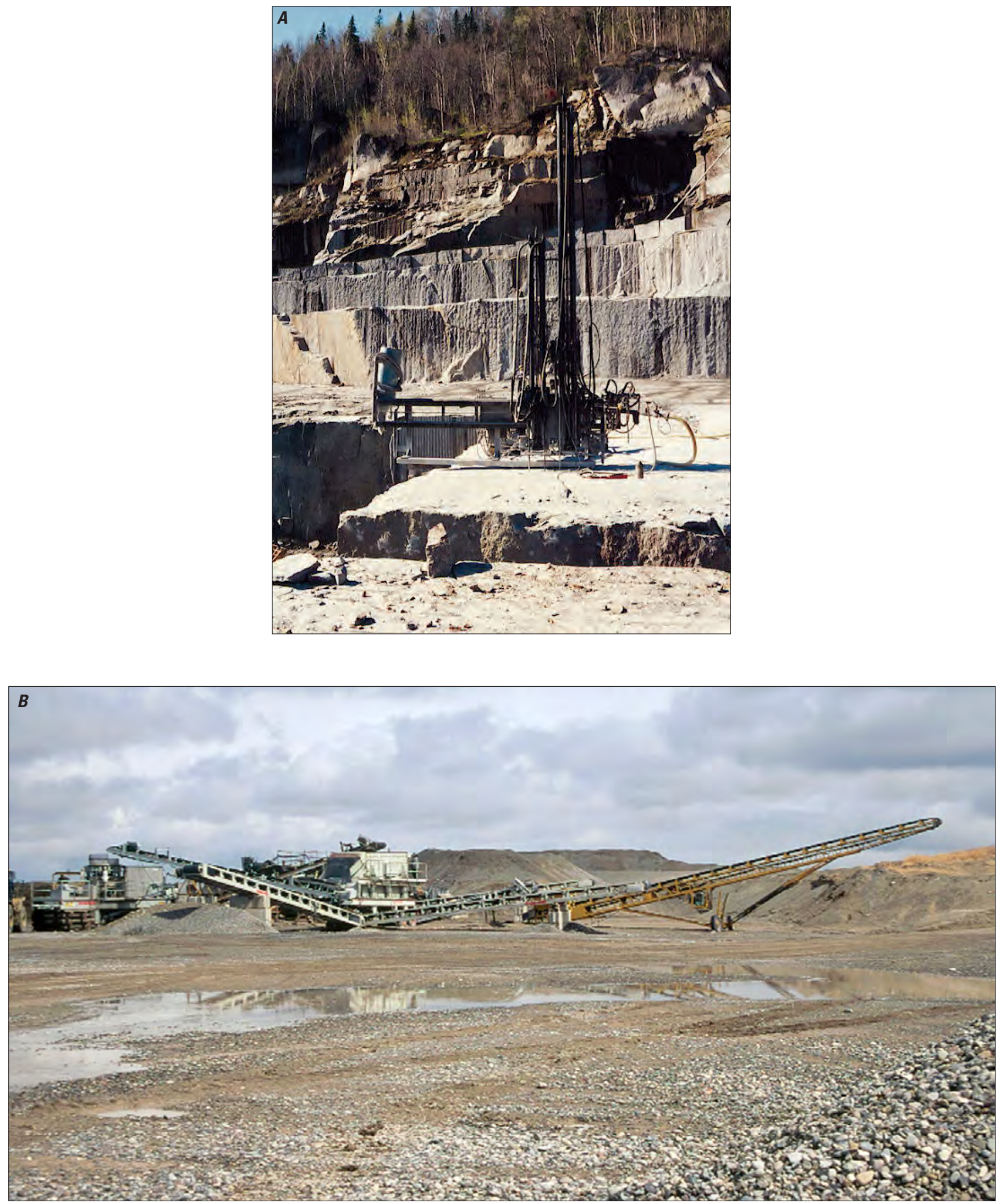

Figure 13. Extraction of granite and of sand and gravel. Extraction is usually followed by beneficiation, which generates some waste. $A$, A drill is used to size blocks of granite to be extracted from a quarry. Photograph by William Langer. $B$, After extraction, sand and gravel may be crushed, screened to classify by size, and stored at the mine site. Photograph by B. Arbogast. 
Table 6. Average unit price of, reliance on imports of, recycling of, and substitutes for certain industrial minerals (modified from U.S. Geological Survey, 2004, except as noted).

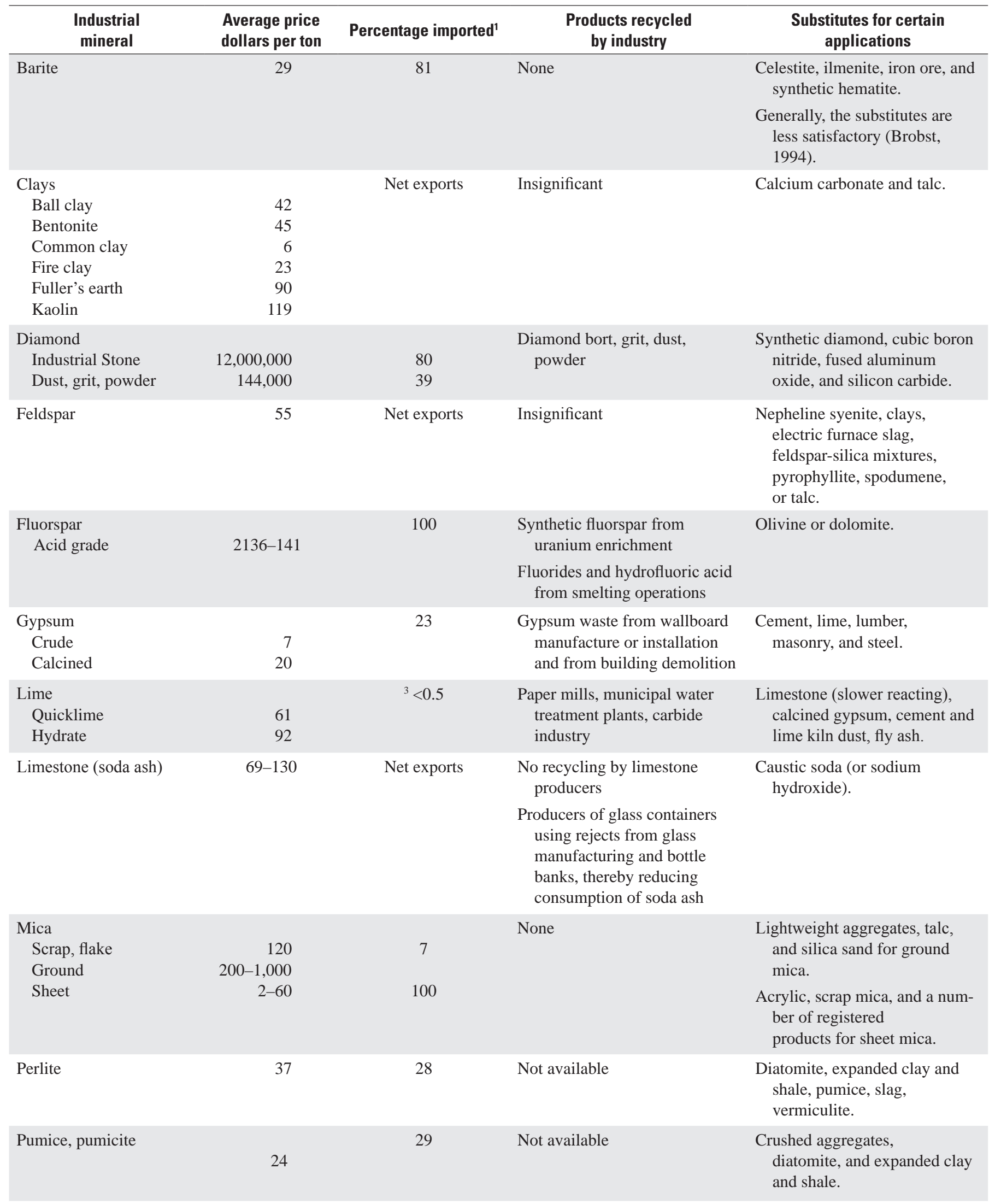


Table 6. Average unit price of, reliance on imports of, recycling of, and substitutes for certain industrial minerals (modified from U.S. Geological Survey, 2004, except as noted).-Continued

\begin{tabular}{|c|c|c|c|c|}
\hline $\begin{array}{l}\text { Industrial } \\
\text { mineral }\end{array}$ & $\begin{array}{l}\text { Average price } \\
\text { dollars per ton }\end{array}$ & Percentage imported ${ }^{1}$ & $\begin{array}{l}\text { Products recycled } \\
\text { by industry }\end{array}$ & $\begin{array}{l}\text { Substitutes for certain } \\
\text { applications }\end{array}$ \\
\hline $\begin{array}{l}\text { Sand, gravel } \\
\text { (construction) }\end{array}$ & 5 & $<0.5$ & $\begin{array}{l}\text { Asphalt road surfaces, } \\
\text { cement concrete surfaces } \\
\text { and structures }\end{array}$ & Crushed stone. \\
\hline Sand (industrial) & 20 & Net exports & $\begin{array}{l}\text { Foundry sand and recycled } \\
\text { cullet (pieces of glass) }\end{array}$ & $\begin{array}{l}\text { Chromite, olivine, staurolite, } \\
\text { and zircon sands. }\end{array}$ \\
\hline $\begin{array}{l}\text { Stone (dimension) }{ }^{4} \\
\text { Marble } \\
\text { Granite }\end{array}$ & $\begin{array}{r}865 \\
1013\end{array}$ & 86 & Small amount by restorers & $\begin{array}{l}\text { Aluminum, brick, ceramic } \\
\text { tile, glass, plastics, resin- } \\
\text { agglomerated stone, concrete } \\
\text { and steel. }\end{array}$ \\
\hline $\begin{array}{l}\text { Titanium dioxide: } \\
\text { Rutile }\end{array}$ & 1,800 & Net exports & & \\
\hline Vermiculite & 143 & 28 & Insignificant & $\begin{array}{l}\text { Perlite, clay, shale, slate, slag, } \\
\text { fiberglass, peat, sawdust, } \\
\text { bark, and other synthetic soil } \\
\text { conditioners. }\end{array}$ \\
\hline $\begin{array}{l}\text { Zeolite }^{6} \\
\text { Natural } \\
\text { Synthetic }\end{array}$ & $\begin{array}{r}85-140 \\
500-600\end{array}$ & Minimal $^{6}$ & A process catalyst & $\begin{array}{l}\text { Synthetic zeolite, clays, } \\
\text { dolomite, diatomite and } \\
\text { pumice, activated carbon. }{ }^{7}\end{array}$ \\
\hline
\end{tabular}

${ }^{1}$ Percentage imported = imports - exports + adjustments for Government and industry stock changes; stock changes assumed to be zero.

${ }^{2}$ Miller (2001); average U.S. Gulf port price for Chinese acid grade.

${ }^{3}$ Miller (2004a).

${ }^{4}$ Obtained from European Union; for a ton of processed natural stone, North American buyers pay 50 percent more than European Union buyers pay (KD Resources, 2003).

${ }^{5}$ Titanium mineral concentrates in bulk, “freight on board” from Australian ports.

${ }^{6}$ Virta (2003).

${ }^{7}$ Christie and others (2002); synthetic zeolite is detergent grade.

the construction materials. Barite, diamond, fluorspar, mica, nahcolite, silica sand, titanium oxides, and zeolite minerals all have a high unit value. These special industrial minerals are used in the manufacture of chemicals, abrasives, paint, specialty ceramics, glass, semiconductors, refractories (heatresistant products such as the lining of furnaces used to make steel), fertilizers, absorbents, insulating materials, and even prepared foods.

The materials considered to be industrial minerals (table 5) are fairly common in nature, but their occurrence in concentrations and volumes large enough to be of economic value requires that a combination of geologic processes operate under the right conditions, sometimes for millions of years. Some industrial minerals, such as crushed stone, are extremely abundant and virtually inexhaustible in central Colorado. Others, such as barite, are in much more limited supply. In chapter 4, each commodity's use, geologic origin in Colorado, mining, and production is discussed.

\section{Care of Physical and Cultural Landscapes}

Long-term planning, management, and reclamation of pits and quarries are encouraged in response to concerns about the visual, physical, biological, and socioeconomic environments 
surrounding the development of industrial mineral resources. Exploration and production activities can have considerable effect on the site and the surrounding community. The contrast between excavated and unexcavated areas, alterations in topography and landform, changes in vegetative cover, disturbance of local fauna, and response to regional resource needs may need careful consideration. Careful planning and design can address potential effects from an engineering, ecosystem, visual, and socioeconomic perspective. Proper site investigation, planning and location, reduction of unnecessary disturbance (such as minimizing road widths and restoring vegetated areas as soon as possible), making the site less visible (such as retaining as much existing vegetation as possible and screening the operation from public view), and sensitivity to the site's ecoregion character (defined by its soil, hydrologic function, climate, and natural processes) all help mitigate a project's immediate effects (U.S. Bureau of Land Management, 1984).

The cultural landscape contains both natural and manmade components (fig. 14). "A natural landscape or ecosystem is one that developed by natural processes and that is self-organizing and self-maintaining” (Society for Ecological Restoration, 2004). Special scenic areas, unique geologic landscapes, and critical habitat may be declared off-limits to mineral development. Remote areas that are intended to be used by backcountry campers may not be as suitable for mineral development as areas that are already built up with roads and other facilities. Careful environmental assessment and collaborative planning can establish preferred mining sites.

Preserving religious or archaeological sites respects the cultural needs of Native peoples (fig. 15). Lafarge North America considered mining a 120-acre site, which includes an old pumice mine, adjacent to ancestral lands of the Santa Clara Pueblo in Rio Arriba County, N. Mex. In 2005, the company instead donated the land and a sum of money for its reclamation to the pueblo (Lafarge North America, 2005).

Literature discussing the prediction and management of environmental issues in mining can be found in publications from a variety of sources:

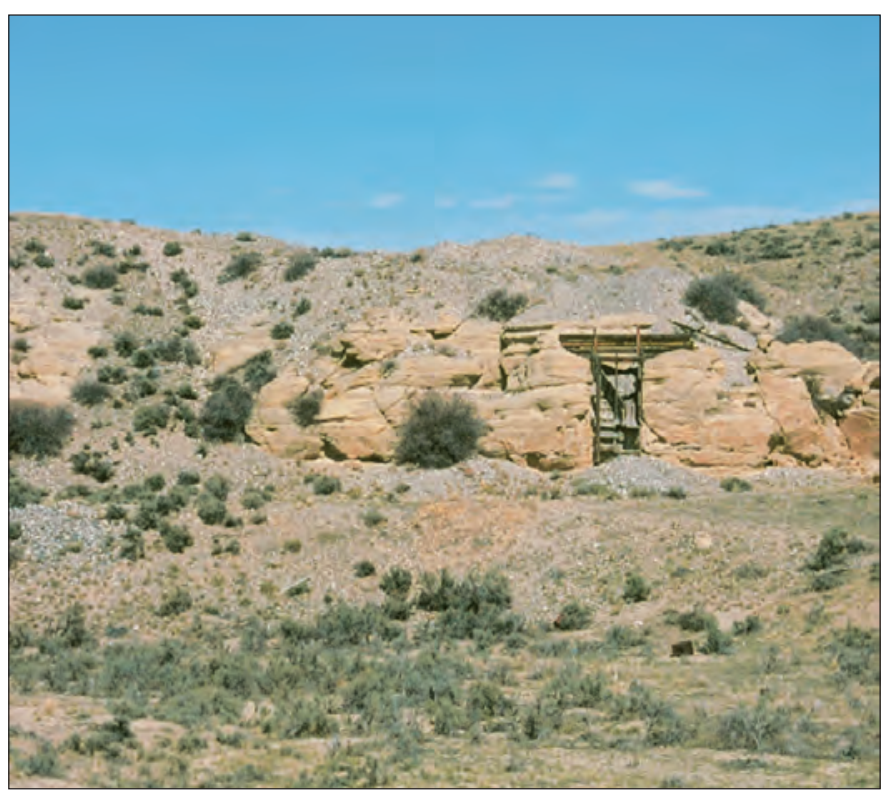

Figure 15. Gravel tip and rocky outcrops on the Wind River Reservation, Wyo., 2005. The establishment of native plants to reclaim sand and gravel pits is important to Eastern Shoshone and Northern Arapaho tribes. The tribes retain traditional values, and many plants in the sagebrush ecosystem are used as medicines and in ceremonies. Photograph by B. Arbogast.
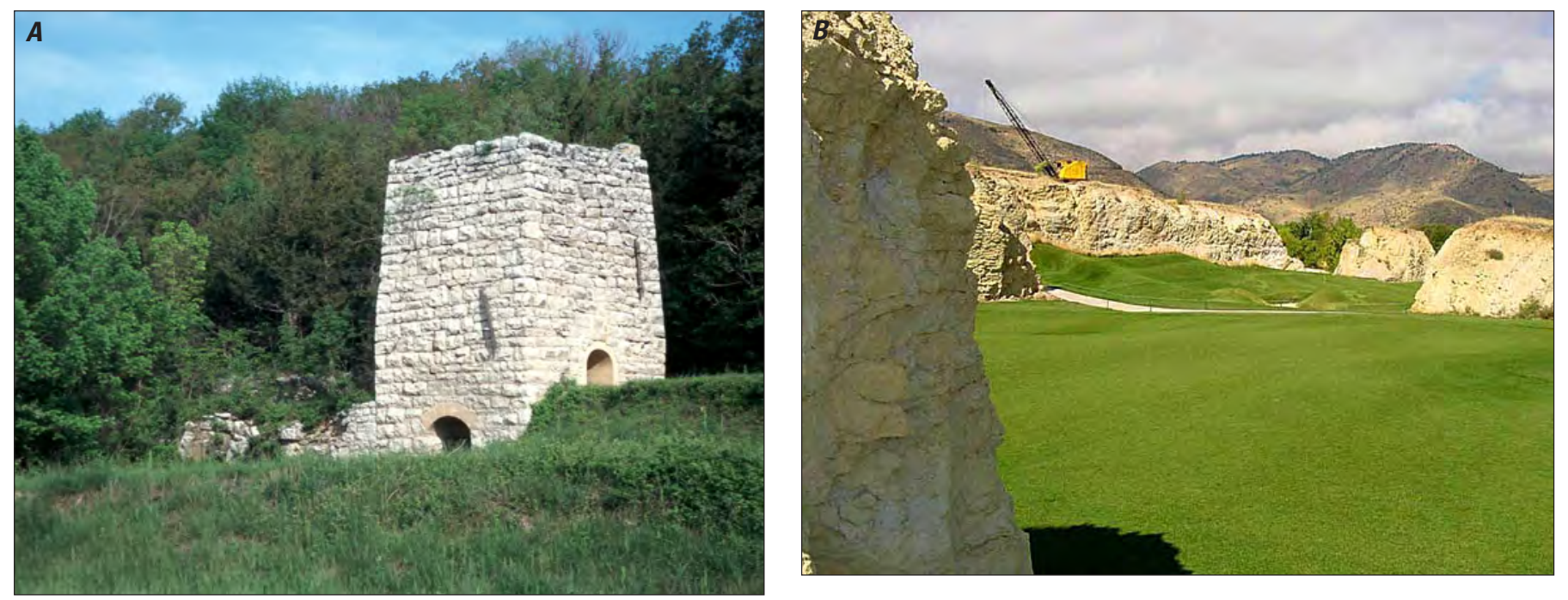

Figure 14. Landscapes can contain both natural and manmade features. A, An 1800s lime kiln near St. Louis, Mo., contributes to a picturesque scene. Photograph by B. Arbogast, 2002. B, Carved out of an old clay quarry, Fossil Trace Golf Club is owned by the city of Golden, Colo. The crane was used to remove clay units between sandstone layers. Courtesy of Fossil Trace Golf Club. 
- Academia (for example, Darmer, 1990, Landscape and surface mining-Ecological guidelines for reclamation)

- Industry (for example, National Stone Association, 1995, Environmental management guide)

- State and Federal agencies (for example, Buttleman, 1992, A handbook for reclaiming sand and gravel pits in Minnesota; Norman and others, 1997, Best management practices for reclaiming surface mines in Washington and Oregon; Colorado Department of Natural Resources Division of Minerals and Geology, 1998, In-stream aggregate extraction and reclamation guidance document; Environment Australia, 2002, Overview of best practice environmental management in mining; and Wright and White, 2004, The practical guide to reclamation in Utah)

- Scientific journals (for example, Journal of Environmental Management; Landscape Research; and Landscape and Urban Planning)

- World Wide Web sites sponsored by the Environmental Protection Agency, U.S. Geological Survey, USDA Forest Service, Bureau of Land Management, and Office of Surface Mining, such as the following:

- $h t t p: / / w w w . e p a . g o v / e p a h o m e / s c i t e c h . h t m$

- http://www.usgs.gov/pubprod/

- http://www.fs.fed.us/publications

- http://www.blm.gov/nhp/index.htm

- http://www.osmre.gov/resources/Ref/References.shtm

\section{Exploration Activities}

Exploration for additional industrial minerals proceeds by stages (Bates, 1969; Peters, 1978).

\section{Marketing Study}

First, a marketing study inventories known resources and deposits on the basis of written reports, small-scale regional geologic maps (U.S. Geological Survey $1^{\circ} \times 2^{\circ}$ geologic maps are particularly useful), aerial photographs, a site visit, and visual assessment. If this marketing study supports the venture, a detailed project plan of the mine or quarry is then prepared. Exploration field work follows, using techniques such as random sampling and field checks of known occurrences; exploration by grid pitting, trenching, and drilling; and laboratory testing of samples (discussed in the next section).

A second-stage feasibility study will contain results of these exploration studies. The report evaluates geologic, economic, and environmental aspects of mining the property: mineral reserves, composition, and characteristics; location, access, and transport; mineral, water, and surface rights; water and energy supply; mining method, manpower, and production capacity; and protection of the environment (Kuzvart, 2003).

\section{Geological and Geophysical Exploration}

Geologic examination, usually by mapping, can determine the areal extent of a mineral occurrence and those soil and bedrock properties that indicate difficult or unstable ground conditions. On a microscopic scale, geologic examinations of the rocks can yield information about the type, size, shape, and proportions of mineral grains, their interlocking nature, and the amount and interconnectedness of pores and fractures in the rocks. Such attributes determine rock strength and stability. Mapping has little or no effect on the land surface, but drilling, trenching, and pitting (discussed in the next section) will disturb the land surface. Usually the changes are small and are straightforward to reclaim.

Geophysical techniques can be used to determine the subsurface characteristics of a mineral deposit and complement the geological mapping. For example, geophysical investigations can be used to measure the depth of overburden, map sedimentary strata, and help determine the structural or geological stability of mine faces. It can also determine anomalies (local distortions within the overall pattern) or structures that may affect the mining of the deposit (such as geologic faults, cavities, or old mineshafts). Which of the many geophysical techniques are used depends on the type of information sought, the local geology, and features such as roads or buildings that may skew certain kinds of geophysical measurements. Surveys can be run from the ground or from the air, depending on the scale and objectives of the investigation. Airborne methods have no environmental effect other than the brief passage of an airplane or helicopter. Active methods transmit energy into the Earth; passive methods do not. Passive geophysical exploration methods-gravity, radiometric, and magnetic surveys - measure natural properties of sediments and rocks. Like geological mapping, they have essentially no environmental effect.

Active methods include most electrical and seismic surveys (fig. 16). Electrical methods measure various electrical properties and generally have a very limited environmental effect. Seismic surveys measure the properties of waves that pass through the Earth and may cause limited environmental effects. Small-scale site surveys commonly use a sledgehammer, a portable steel plate, and a recording device; consequently they leave few traces in the environment. On the other hand, large-scale regional seismic surveys, such as those used in petroleum exploration, use trucks to move specialized equipment across the land surface. These surveys commonly cause some environmental damage that may require reclamation.

\section{Sampling and Analysis}

The feasibility of any mining project depends chiefly on the size of the deposit (its thickness and depth) and the quality or grade of the deposit (its ratio of useful to useless 


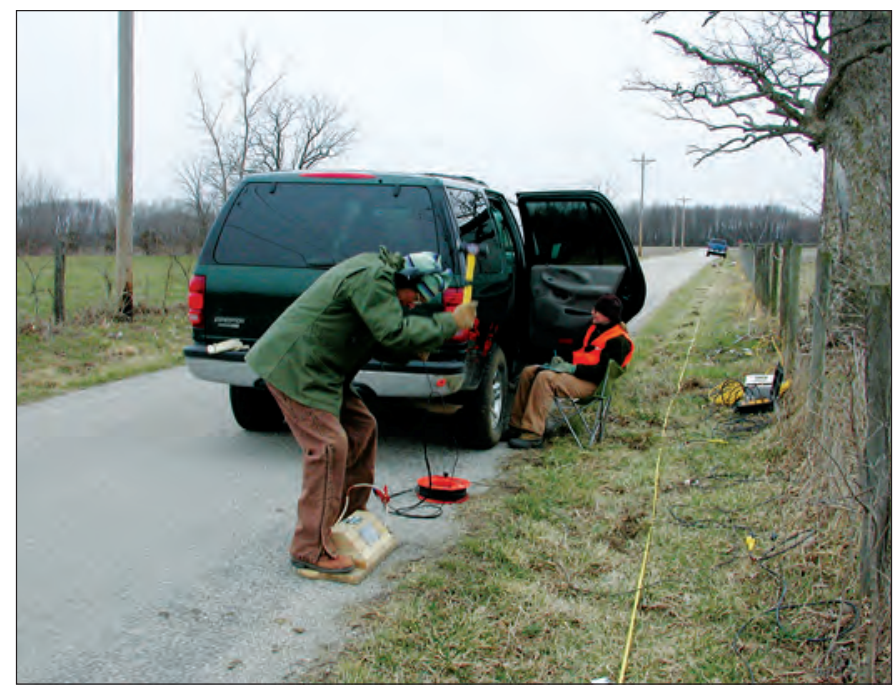

Figure 16. Geologists collecting shallow seismic data to help assess aggregate deposit thickness and character. Photograph by J.E. Lucius.

components). Well-designed sampling programs, which usually go hand in hand with calculations of size or reserves, can determine quality or grade. Sampling can be as simple as grab samples (hand-sized samples) from selected outcrops or exposures such as road cuts. Or, a gridded sampling program may sample densely enough to record all the variability in a deposit. Sampling programs may combine large samples taken from various points in the deposit to produce a composited or bulked sample that may range from a few hundred pounds to several tons. The most ambitious investigations combine bulk sampling with a pilot plant on the mine site to test the planned recovery process.

Drilling is one way of physically sampling the subsurface of a deposit. Not only does the drilling program provide information on the lithological variation of a deposit, but samples can also be analyzed for other chemical and physical properties. Depending on the samples required, the drilling program might use core-drilling machines or rotary or hammer drills, which provide chips and fragments. Drilling programs may construct drill pads, access roads, pits for water storage, and other temporary facilities. If the drilling and sampling program is unsuccessful in delimiting a mineable deposit, then the drill sites and roads will be reclaimed.

Other types of sampling can cause limited to moderate effects on the land surface. Bulk sampling usually requires use of trenching, blasting, and haulage equipment on the site. Some reclamation work is usually required. A pilot plant is usually a scaled-down version of the final proposed plant and mine. Environmental effects, depending on the size of the operation, can differ; however, most pilot plant operations are a precursor to actual full-scale mining, and the repair and reclamation of environmental changes are generally completed as part of the approved mine plan.
Analysis of a deposit's chemical or physical properties is almost always required before the economic viability of the deposit can be determined. Geochemical or petrologic sampling and analysis can distinguish the physical attributes of the deposit (such as composition, abundance of elements in the mineral, grain size, texture, and lithology). A geochemical analysis might determine the calcium carbonate content of a limestone or chemical impurities in a gypsum deposit. Very pure and treatable industrial minerals are needed for certain manufactured materials_-such as composites, special ceramics, superconductors, and optical fibers-but such deposits or reserves are usually small (Kuzvart, 2003). Knowing the physical properties of raw materials is important, given the common need for large volumes of a uniform product that meets stringent specifications. In order to lay the highly durable asphalt pavements called "Superpave,” for example, highway engineers specify aggregate that meets criteria for angularity of coarse aggregate, uncompacted voids in fine aggregate, flat and elongated particles, clay content, and gradation parameters (Pavement Interactive, 2008). Moreover, aggregate should be free of certain types of impurities, such as opalescent quartz, which may react with lime in cement and cause the concrete to disintegrate (U.S. Environmental Protection Agency, 1995a) (fig. 17).

The feasibility studies and mineral exploration program are followed by detailed project drawings of the mine or quarry and its buildings and infrastructure. Mapping, sampling, drilling, and geophysical programs provide the raw data needed to develop a mine plan. Computer programs can manipulate data on grade and size of an ore deposit and develop a mining plan that allows for efficient mining of the resource. Once the mine plan has been determined and all permits have been acquired, the deposit can be developed.

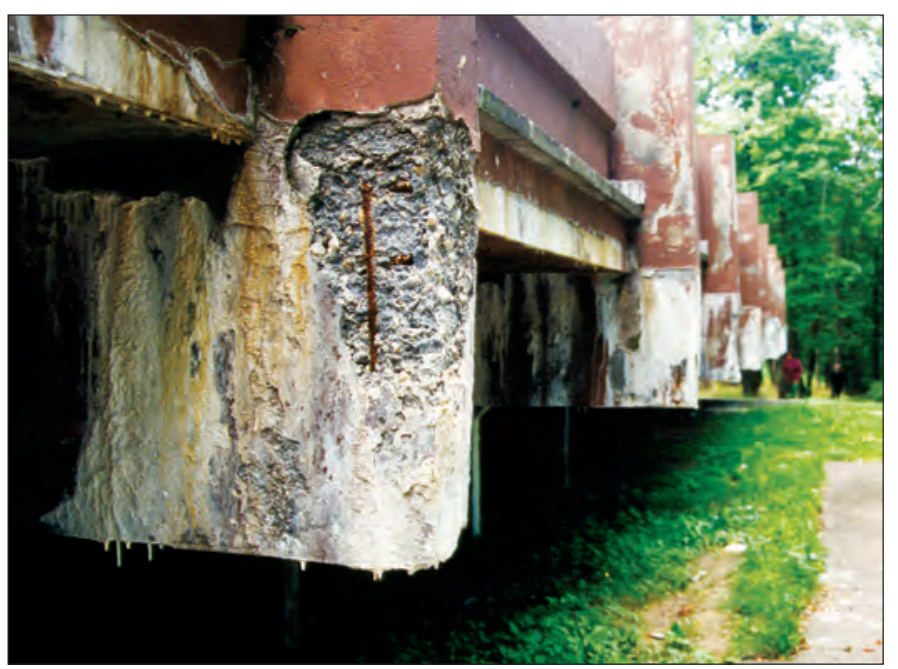

Figure 17. Deteriorated concrete bridge pillars. Unstable silica in the aggregate reacted with alkali in the cement; the resulting alkali-silica gel may have contributed to the deterioration of the concrete. Photograph by William Langer. 
The exploration program is a small but important part of the development and production of a mineral deposit. The design and implementation of the exploration program can influence not only the eventual mine plan but also the environmental changes that take place during mine operation and eventual reclamation.

\section{The Physical Environment-Geotechnical Concerns}

During a mining operation that causes the physical disturbance of a landscape sound engineering and geologic decisions ensure public safety and proper processing of mineral ore, disposal of waste rock, and reclamation. The chief concerns during earthwork and grading are promoting safety and reducing erosion (Wright and White, 2004). Short-term minor to moderate adverse effects of mining include surface runoff (flow of water over the land), dust, noise, and land disturbance. All of these issues exist at any construction site (even residential building sites) or during road repair and timber harvesting.

\section{Acid Mine Drainage}

The general public may be familiar with environmental problems associated with toxic reagents (such as the leakage of cyanide-bearing solutions from the Summitville open-pit gold mine in Colorado) or the formation of acidic and metal-bearing soils and waters from mining activity (termed "acid mine drainage”) (King, 1995). When certain rock types and mine wastes containing sulfide minerals are exposed to air and water, those minerals (such as the iron sulfide minerals pyrite $\left(\mathrm{FeS}_{2}\right)$ and pyrrhotite $\left(\mathrm{Fe}_{1-\mathrm{x}} \mathrm{S}\right)$ ) can oxidize and produce highly acidic waters with elevated metal concentrations (Alpers and others, 1994). The likelihood that acid drainage will form increases during mining, because the rates of mineral weathering increase greatly during mining and mineral processing (Alpers and others, 1994). Acid rock drainage that is not contained or mitigated (as by buffering with excess limestone or other calcium-bearing rock obtained from cement operations) may contaminate surface water, groundwater, and vegetation. Acid mine drainage is more commonly associated with abandoned hard-rock metal mines (those that recovered gold, copper, lead, or zinc ore) or coal mines rather than industrial mineral mines. Typically, mines that recover industrial minerals have fewer engineering problems compared with metal mines. Processing is simple, and relatively benign waste is produced. However, gaseous and particulate pollutants, blasting with explosives, slope stability, and water quality are concerns in any mining operation.

\section{Air Pollutants and Noise}

Dust typically is a byproduct of the production and processing of minerals (U.S. Environmental Protection Agency, 1995c). It is generated by drilling, blasting, front-end loaders handling and transferring material, trucks on haul roads, mechanical processing (crushing, screening, and grinding) of minerals, and wind erosion of storage piles.

Dust can be difficult to eliminate entirely but usually can be reduced out-of-doors by wet suppression (spraying roads, sites of blasting, stockpiles, and exposed surfaces with water and a surfactant), by covering or enclosing open operations, and by planting windbreaks and other vegetation. Magnesium chloride can be sprayed to reduce dust on dirt roads and tailings (U.S. Environmental Protection Agency, 1995a). Truck wheels can be cleaned before they move from the mine site to public highways and paved roads.

Indoor operations can avoid sending dust to the atmosphere by using hoods and fans to collect dust (dry collection). Most kilns have some sort of dust control, such as fallout chambers, cyclone separator, fabric and gravel bed filters, wet scrubbers, and electrostatic precipitators (U.S. Environmental Protection Agency, 1995c). Machinery such as crushers, vibrating screens that separate crushed material according to size, and conveyor belts can be enclosed.

More serious than the nuisance aspect of dust is occupational exposure, through inhalation, to dust that contains crystalline silica—a kind of dust present in many industries, such as mines and quarries, metal foundries, construction sites, and sites where sandblasting is used. Overexposure to respirable crystalline silica may result in silicosis, a disabling, nonreversible, and sometimes fatal lung disease (U.S. Department of Labor, 2002). A comprehensive program to protect the respiratory health of workers who work with materials that contain crystalline silica contains the following (National Industrial Sand Association, 1997):

- Warning and training workers concerning hazards

- Sampling of crystalline-silica dust

- Engineering controls (such as improved wet drilling, prevention of contamination, removal by exhaust ventilation, dilution with uncontaminated air, and remote handling)

- Good housekeeping

- Medical surveillance of workers’ respiratory health.

"Many minerals or rocks of commercial value contain varying amounts of crystalline silica. Silica can be a predominant constituent or be present only as a minor accessory mineral with minerals of commercial value" (National Industrial Sand Association, 1997). Most industrial rocks and minerals are mined from deposits containing crystalline silica (U.S. Bureau of Mines Branch of Industrial Minerals, 1992). Such rocks and minerals include barite, beach sand, bentonite, calcite, crushed stone, clay, feldspar, granite, gypsum, industrial sand, kaolin, limestone, mica, rutile, sandstone, vermiculite, and zeolite (U.S. Bureau of Mines Branch of Industrial Minerals, 1992; National Industrial Sand Association, 1997).

The U.S. Environmental Protection Agency (1995a) lists the air emissions of particular chemicals, such as carbon monoxide, nitrogen dioxide, total particulates, sulfur dioxide, and volatile organic compounds, according to industry sector 
(table 7). Carbon monoxide, nitrogen dioxide, and sulfur dioxide gases are commonly products of combustion from coal- and petroleum-driven furnaces or dryers. Gasoline- and diesel-powered vehicles used during mining activities are another major source of air emissions. If natural gas is used for fuel, the emittable pollutants resulting from combustion are fewer in volume and number than those from the combustion of any other fossil fuel (U.S. Environmental Protection Agency, 1995c; U.S. Energy Information Administration, 1998).

Explosives are used to displace rock from the quarry face and reduce the size of rock fragments. Larger quarries may blast once a day and smaller operations once or twice a week. The use of explosives and detonators is regulated by Federal and State agency regulations, including those of the Bureau of Alcohol, Tobacco, and Firearms. Selective blasting is used to modify rock benches in mines or quarries, reduce the steepness of walls to make them more stable, and blend highwalls with the surrounding landform.

The intensity of ground vibrations and air overpressure (pressure waves in the atmosphere sensed as noise or concussion (or both)) may not exceed certain limits set by the Environmental Protection Agency. Relations with nearby communities proceed more smoothly when those communities are notified of proposed explosive work well beforehand, haul trucks have effective mufflers, and machinery is fitted with silencers and acoustic housing. Efficient, controlled blasting obtains maximum energy from smaller explosive charges (that do not produce an appreciable air blast) and limits the range of flyrock. Seismographs, laser profilers, and velocity-of-detonation measuring systems can monitor results of blasting. Buffer zones may be needed between the blasting area and surrounding areas - especially those areas where "natural quiet" is required. Tree belts and berms can reduce noise levels and screen activities between a mine site and the surrounding community.

\section{Erosion and Slope Stability}

One of the most commonly encountered engineering problems is maintaining the stability of slopes in quarry walls and waste dumps. Some earth scientists claim that erosion control is the major goal of reclamation (Toy and Hadley, 1987).

Mining (as well as urbanization, agriculture, and forestry) increases the runoff of water, which in turn increases erosion. The erodibility of a particular area is controlled mainly by the nature of the underlying bedrock, the climate, and the steepness of slopes. Generally, igneous and metamorphic rocks and tightly cemented sedimentary rocks are more resistant to physical erosion. Harder rocks such as granite typically form more-stable slopes than do softer rocks such as shale, clay, or gypsum. Shale along Colorado's Front Range weathers to clays that produce gently curving hillslopes, whereas granite weathers to sand and gravel and commonly produces steeper hillslopes (Wohl, 2001).

However, even rocks that may be strong as long as they are underground may weather and become softer or less stable once mining exposes them to air. Site engineers and geologists are interested in identifying the physical and chemical character of the rock or mineral to be mined, the stability of natural slopes (which determines the mining technique to be used), and the extent of the area disturbed by mining in order to predict the effects of that disturbance (fig. 18). Landslides are of particular concern during the rainy season in mountainous regions.

Minimizing the disturbed area, reducing the time newly exposed surfaces are left untreated, and constructing earth walls and spillways can reduce erosion. Extreme surface roughening (pocking, ripping, or gouging) creates a network of many small pits that trap sediment (Wright and White, 2004). Stabilizing the soils that rim a pit or quarry may help to stabilize

Table 7. Volumes (short tons per year) of six pollutants released by industry (modified from the U.S. Environmental Protection Agency, 1995a).

\begin{tabular}{lccccc}
\hline \multicolumn{1}{c}{ Industry } & $\begin{array}{c}\text { Carbon } \\
\text { monoxide }\end{array}$ & $\begin{array}{c}\text { Nitrogen } \\
\text { dioxide }\end{array}$ & $\begin{array}{c}\text { Total } \\
\text { particulates }\end{array}$ & $\begin{array}{c}\text { Sulfur } \\
\text { dioxide }\end{array}$ & $\begin{array}{c}\text { Volatile organic } \\
\text { compounds }\end{array}$ \\
\hline $\begin{array}{l}\text { Nonmetal mining } \\
\text { Motor vehicles, } \\
\text { bodies, parts, and } \\
\text { accessories }\end{array}$ & 4,525 & 28,804 & 167,948 & 24,129 & 1,736 \\
\hline $\begin{array}{l}\text { Stone, clay, glass and } \\
\text { concrete }\end{array}$ & 35,303 & 23,725 & 12,853 & 25,462 & 339,216 \\
\hline $\begin{array}{l}\text { Petroleum refining } \\
\text { Pulp and paper }\end{array}$ & 48,043 & 338,482 & 171,853 & 30,262 \\
\hline Iron and steel & 624,291 & 380,641 & 36,877 & 309,058 \\
\hline
\end{tabular}




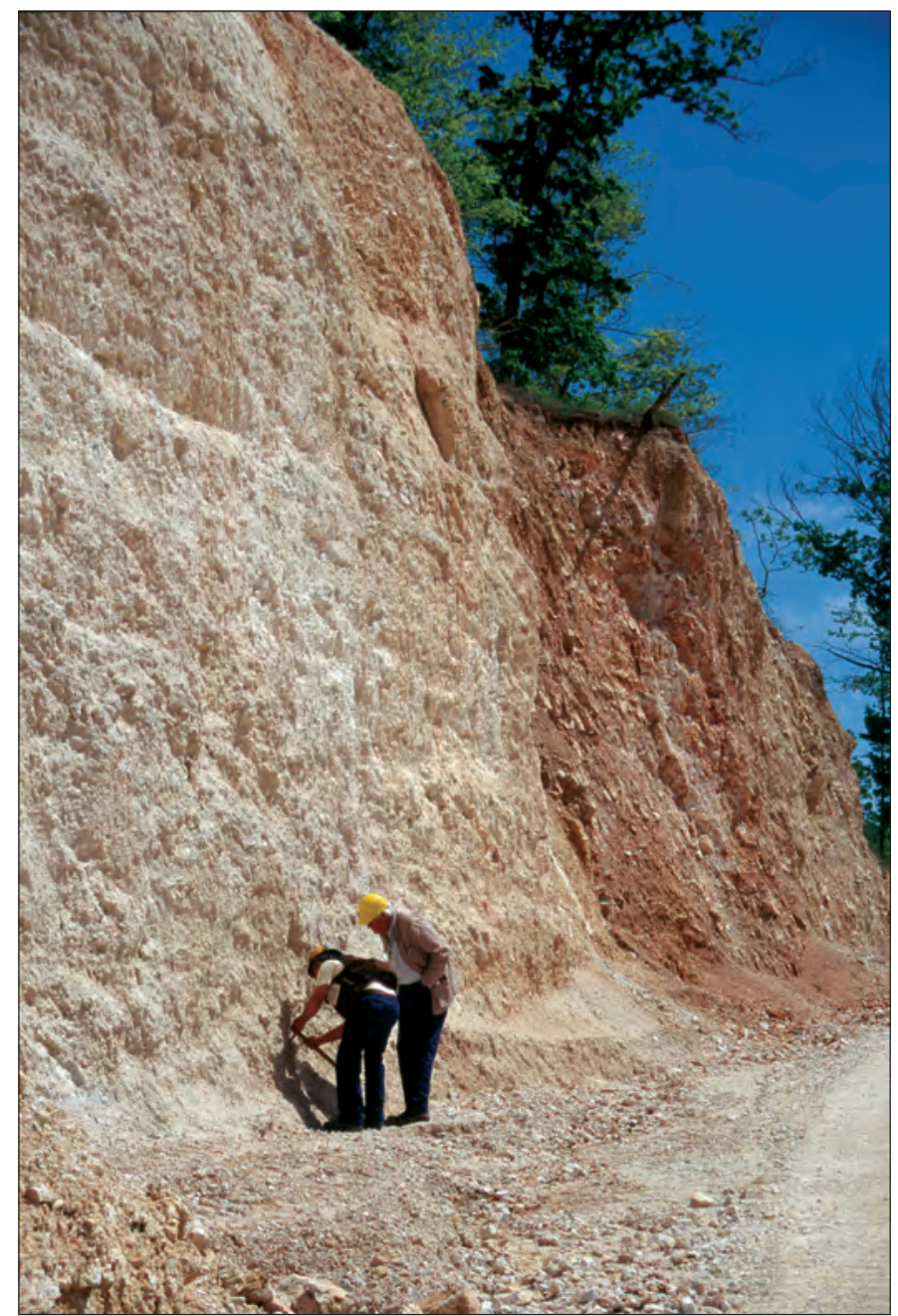

Figure 18. Geologists examine rock face in an industrial sand pit near Tamms, III. Photograph by B. Arbogast, 2002.

their underlying slopes. Limiting surface mine operations during high winds or intense rainfall and using mulches, cover crops, liquid sprays, and geotextiles may help to stabilize soils and thus slopes (fig. 19). Ditches and catchment ponds may be constructed to collect effluents and sediment.

Setting a mine face to a slope angle and slope length that approaches natural slopes can also help reduce erosion. A natural surface slope has a convex or concave profile that merges with a flat section at the toe of a slope and is thought to generally yield less sediment than a straight or uniform slope (Toy and Hadley, 1987). Hill slopes in arid regions tend to be shorter and steeper and have a smaller radius of curvature of the convex element than those in humid areas, and south-facing hill slopes are longer but less steep than their north-facing counterparts. As land is reclaimed, the intended postmining land use will influence the design of the final landform. Flat areas are suitable for playing fields but are unnecessary for forests or grazing. Reduction of back slopes, replacement of topsoil, and revegetation are

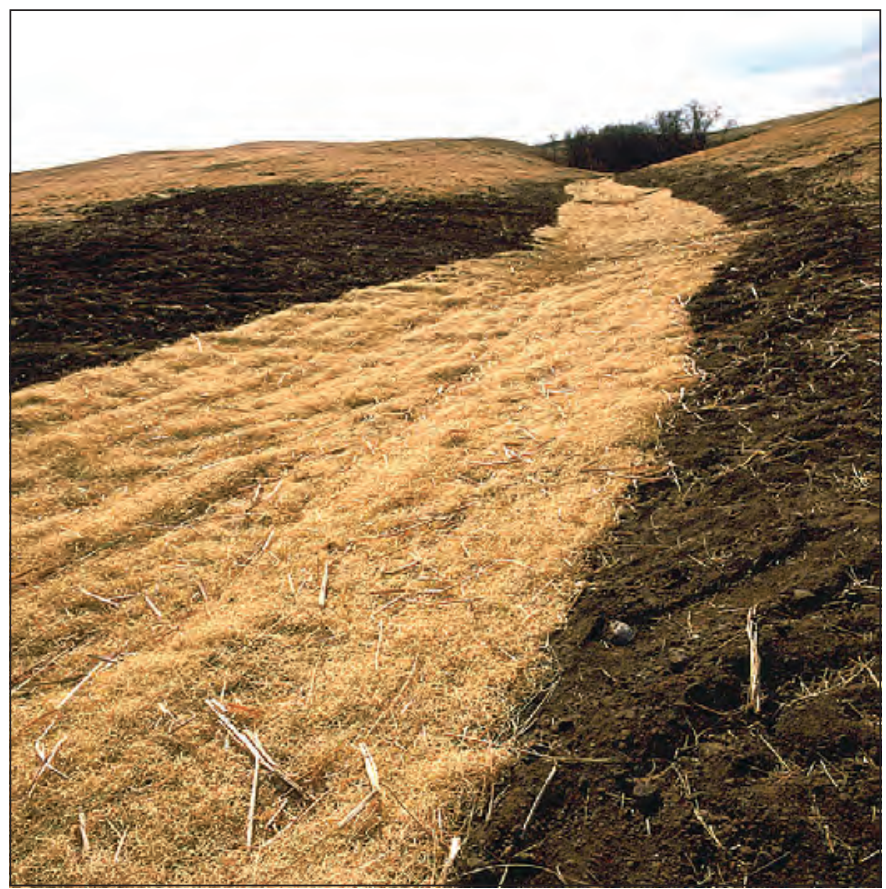

Figure 19. Wood-fiber netting at Glenharold mine, North Dakota. The netting helps prevent erosion until grass is established. Courtesy of Chuck Meyers, Office of Surface Mining, Washington, D.C.

standard activities in reclaiming the mined land and reducing erosion as soon as possible.

The height, length, and steepness of mine faces (highwalls) or the slopes of mine-waste piles strongly influence their stability. Mine engineers and geologists monitor potential hazards such as rock falls or landslides from mine faces or the collapse of mine-waste piles. Highwalls also impinge on the visual landscape. Guidance on appropriate slope gradients and bench heights differs according to regulatory authorities and is influenced by the erodibility of the material in question and local hydrologic processes. In order to prevent slope failure, safety regulations may forbid highwall slopes greater than $45^{\circ}$ or even less if the slopes might be unstable (Wright and White, 2004). In an arid environment, slopes may be constructed with a gradient of no greater than $20^{\circ}$ and with benches every 7-10 m (approximately 23-33 ft) of vertical height (Gratzfeld, 2003).

Mine wastes may be used as backfill against a mine wall to minimize the problem of surface disposal of the waste elsewhere and minimize surface subsidence by filling in underground voids (U.S. Environmental Protection Agency, 1995a). However, backfilling consumes energy, precludes mining reserves, and may destroy wildlife habitat created by the excavated pit. Each mine site will have its own set of engineering requirements. 


\section{Water Management}

Water is nearly everywhere in mining operations. It is naturally present as groundwater in many mines; it is used during mining and in the processing of industrial minerals. A comprehensive water management plan characterizes aquifers and monitor surface water and groundwater. Rainwater and water used in processing are commonly stored in a recycling pond. Dewatering of mines to lower the water table within the site may be necessary through pumping or dewatering wells (for temporary withdrawal of groundwater or to drain water from an upper aquifer into a lower one). In order to prevent or minimize erosion as well as retain water on the mine site, storm-water runoff may be controlled by best management practices such as retention ponds, storm-water conveyances (for example, gutters and sewer), diversion dikes or berms (structures that block runoff), silt traps in drainage areas, graded areas, and vegetation (fig. 20). Effective control measures result from careful consideration of drainage areas, runoff patterns, and discharge points.

When water is withdrawn from a well, groundwater may form an inverted cone of depression around the well that locally lowers the water table (Bates and Jackson, 1987). Similarly, dewatered mines can also lower the water table around them. On the other hand, mine pits can be flooded by overbank river water and by groundwater. Careful hydrologic studies and mine siting can conserve water resources and decrease the risk of water pollution. Creating vegetated

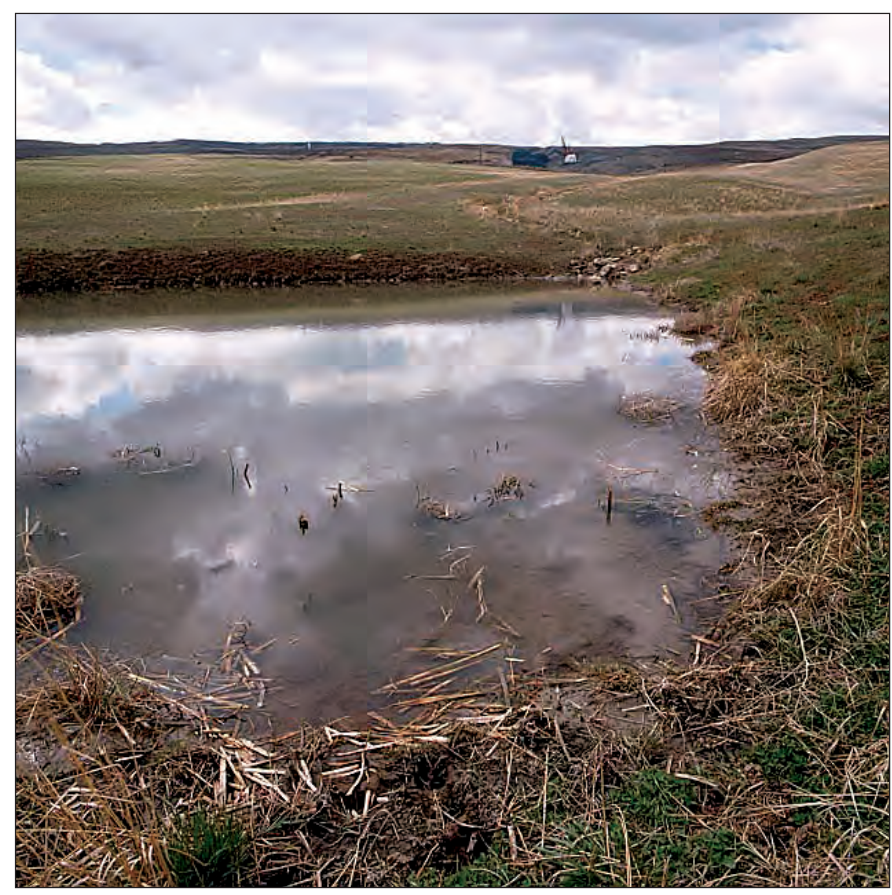

Figure 20. Sedimentation pond at a coal mine site near Craig, Colo. Sedimentation ponds allow sediment to settle from water so that only clear water flows from mine site. Courtesy of Chuck Meyers, Office of Surface Mining. areas and wetlands onsite can help to filter waste and increase groundwater recharge.

Some geologic environments, such as karst areas and active stream channels, are particularly apt to be disrupted by mining. Karst landforms are produced in humid regions when rainwater (enriched in carbon dioxide from organic soils) dissolves subsurface limestone and thus produces sinkholes, cave systems, and valleys in which no streams flow on the surface. Karst topography is more common in the eastern United States than in the West. Gypsum can also be dissolved and removed in groundwater, but ground subsidence in gypsiferous rocks is less common than ground subsidence in limestone. In active stream channels, aggregate can be extracted from riparian zones triggering upstream incision, which can undermine banks and destroy riparian and aquatic habitat, even if the hydrological regime that created those zones is restored. In Colorado, the ground subsidence of greatest concern is associated with sedimentary rocks over abandoned coal and clay mines (Colorado Geological Survey, 2004a).

Flotation is a common method of separating a higher density target mineral from a lower density waste rock. "Processes used to remove mineral impurities can be a major source of water contamination. Flotation, a wet method used to refine certain nonfuel, nonmetallic minerals (sand and gravel, kaolin, potash, phosphate rock) is a potential source of water pollution due to the chemicals used to separate impurities from the mineral. Flotation involves placing minerals in an acidic or basic bath of chemicals where $\mathrm{pH}$ modifiers such as sulfuric acid, ammonia, and hydrofluoric acid are used to control $\mathrm{pH}$ levels in order to separate impurities from the target mineral. Additional materials may be added to the flotation bath to assist in removing impurities, including frothers, conditioning agents, sulfonated oils, and heavy alcohol” (U.S. Environmental Protection Agency, 1995c). Sensors on flotation equipment can reduce the amount of flotation reagents needed (U.S. Environmental Protection Agency, 1995c). Alternative procedures that use organic chemicals to separate minerals of interest from waste remain under development; such procedures may make processes such as acid leaching and heavy media separation safer for the operator and for the environment.

Mine operations may pollute groundwater or surface water by accidental spills of fuels, oils, or solvents and of nitrates or ammonium used in blasting. Hazardous materials, such as petroleum in tanks, are commonly stored within a bermed or diked area to contain any spills, and ponds into which tailings are fed may be impounded.

\section{The Biological Environment—Flora and Fauna}

The development of mineral resources and conservation of biodiversity need not conflict. Embracing environmental fitness (healthy, self-organizing systems) may satisfy both aesthetic and functional landscape needs (Carlson, 2001). Federal agencies are required to ensure that mining activities do not adversely affect the habitat of a Federal- or State-listed threatened or endangered species (U.S. Environmental Protection 


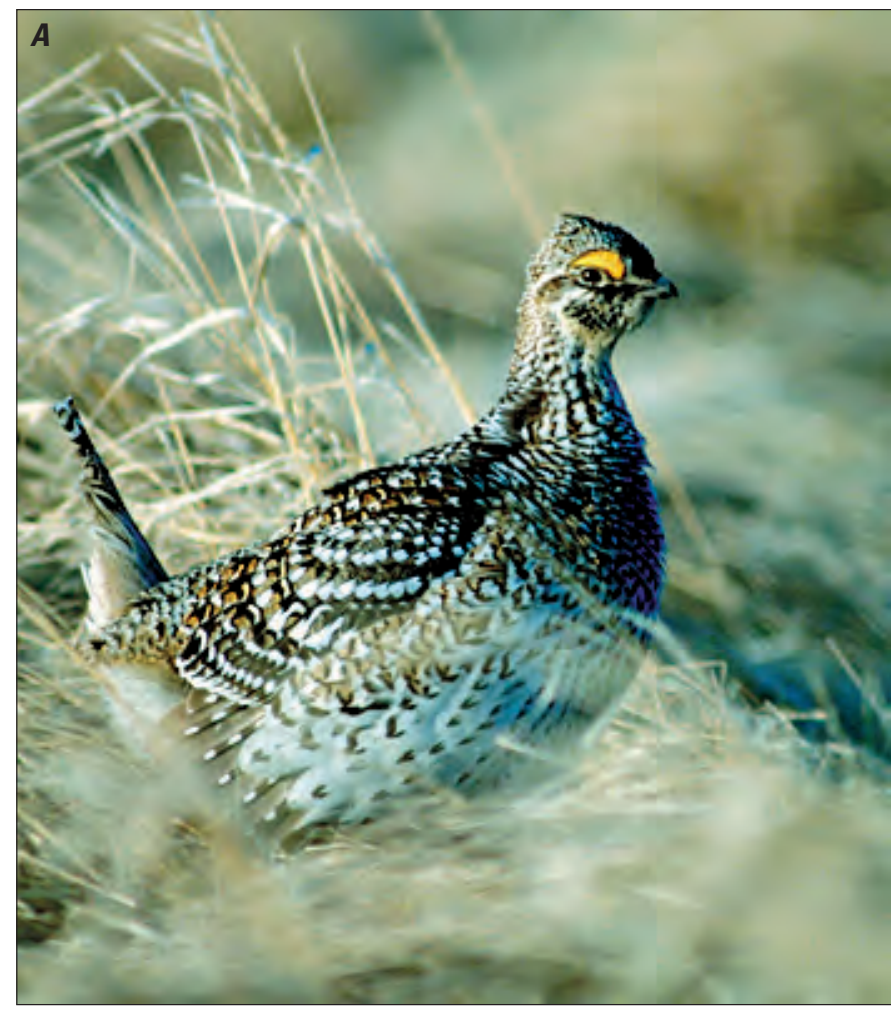

Agency, 1995a). Forest managers may take into account the best available science to protect air, water, wildlife, and other natural resources that make up a landscape.

Federal agencies undertaking a Federal action (such as a BLM review of proposed mining operations) are required to consult with the U.S. Fish and Wildlife Service, which may require an environmental impact assessment. If certain critical habitats are identified, mining operations may be relocated or they may be suspended during seasonal migrations or breeding. Or, the protected species may be relocated. For example, near Orlando, Florida, Tarmac America's Center Sand facility captured and relocated a protected species, the burrowing gopher tortoise (Gopherus polyphemus) (Mineral Information Institute, 2004).

In Colorado, the Federal and State lists of endangered or threatened species and list of animals of special concern contain 23 species of fish, 7 of amphibians, 10 of reptiles, 2 of mollusks, 19 of birds, and 13 of mammals (Colorado Department of Natural Resources Division of Wildlife, 2003). Properly planned mine sites may help with the recovery of some species. Underground mines have been secured for bat habitat. Around reservoirs and wetlands reclaimed from mined-out sand and gravel pits, mudflats could become nesting areas for the endangered whooping crane (Grus americana); sandy or pebbly beaches could become nesting habitat for the endangered least tern (Sterna antillarum) and the threatened piping plover (Charadrius melodus). The creation of quiet, warm backwaters could help the spawning of Colorado pikeminnow fish (Ptychocheilus lucius, a Federal endangered and State

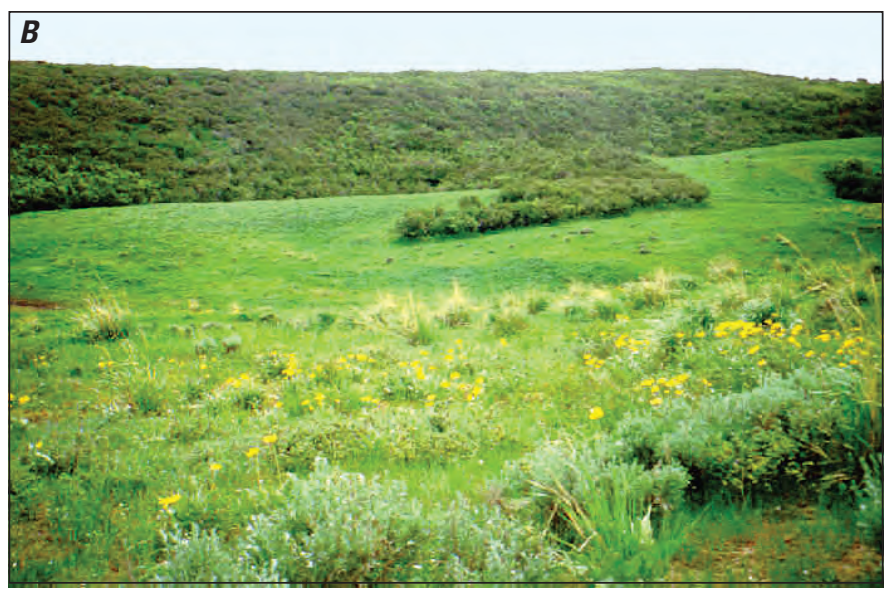

Figure 21. The Columbian sharp-tailed grouse $(A)$ is a Colorado native species of State special concern and was reestablished at the Trapper Mine on reclaimed land $(B)$ near Craig, Colo. Courtesy of Minerals Information Institute.

threatened species). Although the Columbian sharp-tailed grouse (Tympanuchus phasianellus columbianus, a species of State special concern) population has declined over most of its western range, its numbers are increasing on reclaimed mined land at Trapper Mine, a surface coal mine in northwestern Colorado (Raabe, 2002) (fig. 21).

In arid and semiarid lands of the western United States, the scarcity of water may limit revegetation, and irrigation is an essential component of plans for establishing seedlings (National Academy of Sciences, 1974) (fig. 22). High altitude and a short growing season also make revegetation difficult. Moreover, disturbed land - such as around mining operations-may create new niches for nonnative invasive plants that also compete for scarce water.

Avoiding the spread of noxious weeds is always a goal in reclamation work. Concurrent reclamation practices, reestablishing vegetation on all bare ground as soon as possible, minimizing the creation of bare soil and removal of trees (particularly on south-facing aspects), and removing seed sources (for example, pressure washing mining equipment to remove dirt and plant material before transporting that equipment to the mining site, mowing or treating noxious weed plants, using weed-free mulch) may help to preclude introduction of nonnative vegetation into high-ecological-risk areas.

Ecosystems are much easier to restore if local topsoil and plant species have been retained. Collecting native seeds, using cuttings, establishing transplants, removing invasive species, reproducing local norms of minimum plant density, and controlling potential damage to new plantings by wildlife or livestock are all a part of establishing new vegetation. Much research is needed to define seed mixtures that will produce diverse, adapted plant communities. Optimum vegetative stability requires slopes of less than 25 percent (Toy and Hadley, 1987). "Small or long, linear disturbances, such as roads or pipelines, can revegetate naturally without seeding if good 

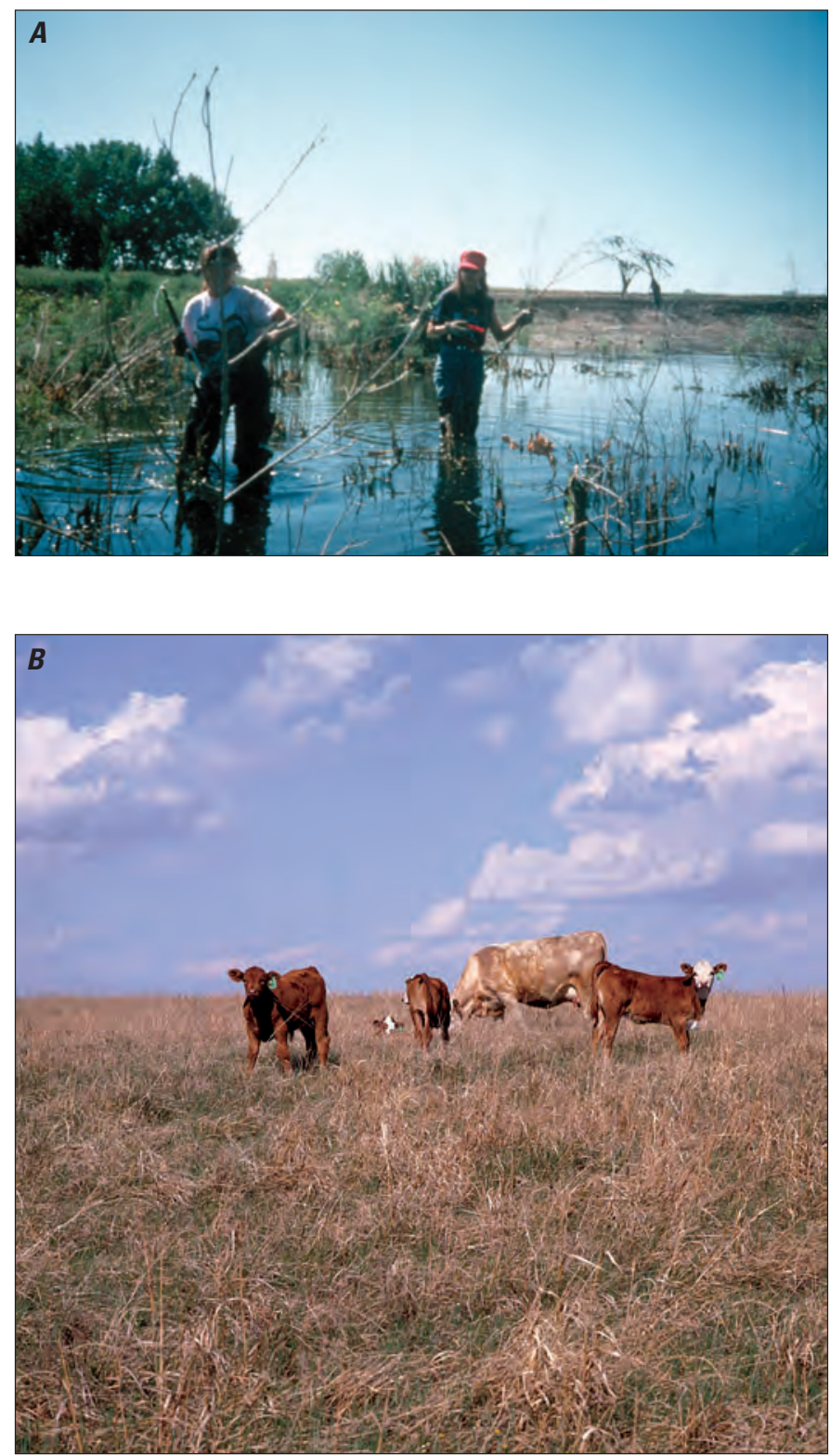

Figure 22. Revegetation of mined lands depends on the local soil types, nutrient status, and climate conditions. $A$, Field checking vegetation established in a former sand and gravel pit, Wren Pit project, Fort Collins, Colo., 1996. Photograph by B. Rolle. B, At a North Dakota coal mine, reclaimed land is seeded in native grasses in late spring or early summer. After two or three growing seasons local ranchers begin to graze their livestock. Courtesy of Chuck Meyers, Office of Surface Mining.

topsoil handling techniques are practiced" (Wright and White, 2004, p. 89). Research by Colorado State University, the Colorado Division of Minerals and Geology, the Colorado Division of Wildlife, the U.S. Soil Conservation Service, and the USDA Forest Service continue to improve techniques for seeding, replacing topsoil, and other aspects of revegetation.
Mining operations may cause the loss of desert varnish, a coating on exposed rock surfaces in certain arid regions. The varnish is a thin brown to black patina formed during thousands of years by bacteria cementing windborne deposits of clay, iron, and manganese oxide minerals (fig. 23A). Coating vertical mine surfaces with certain oxidizing agents can simulate the colors of natural desert varnish. Cryptobiotic crusts may also be important in arid and semiarid plant communities (Belnap, 2003) (fig. 23B). These soil crusts, which are dominated by cyanobacteria, lichens, and mosses, intercept rainfall, stabilize surfaces, and contribute fertility to dryland ecosystems (Belnap, 2003). Recovery times for disturbed biological crusts are generally measured in decades or centuries (Belnap, 2003). It may help to separately salvage the top inch of dry crust material from topsoil and spread it as thinly as possible over topsoil storage piles to keep the piles active (Wright
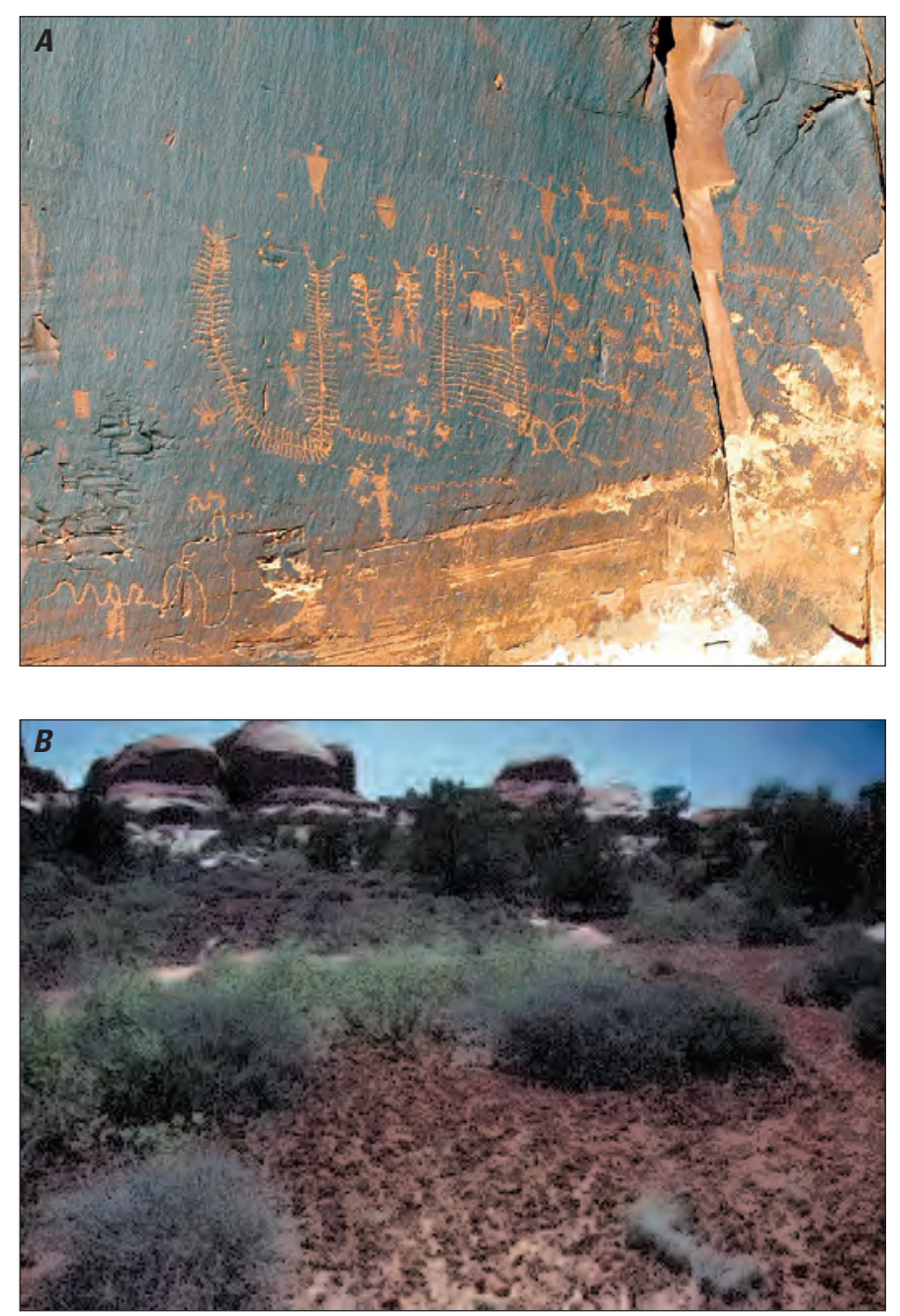

Figure 23. Two types of coatings on arid-region rock faces. $A$, Native American peoples used stone tools to cut line drawings (petroglyphs) through dark desert varnish on a rock face outside Moab, Utah. Photograph by B. Arbogast, 2005. B, Cryptobiotic crusts (foreground) on the Colorado Plateau. Photograph by Jayne Belnap. 
and White, 2004). However, large disturbed areas may never recover although, under the best circumstances, a thin veneer may return in 5 to 7 years (Belnap, 2003).

Mine reclamation is most successful when those in charge recognize the role of time and space in working with processes such as vegetative succession or soil sedimentation and erosion. Plant communities reestablished on bare ground take time to develop high diversity. Because most people are aware of only those landscape changes that take place within a few decades, they commonly do not recognize landscape changes that may have occurred during longer periods of time (Wohl, 2001). For example, Front Range rivers appear relatively natural now partly because few people know how the rivers may have looked 200 years ago (Wohl, 2001). Few people recognize former mines within the Denver, Colo., metropolitan area, now that the sites have been reclaimed for water storage, wildlife or greenbelt space, multipurpose reservoirs, or uses such as light industrial districts or residential housing (Arbogast and others, 2000).

"Cumulative impact" is the impact on the environment which results from the incremental impact of the action when added to other past, present, and reasonably foreseeable future actions regardless of what agency (Federal or non-Federal) or person undertakes such other actions. Cumulative impacts can result from individually minor but collectively significant actions taking place over a period of time" (40 CFR Sec. 1508.7). For example, one mine may not be noticeable on a landscape but as the number of mines increases over time, the effect may become noticeable in a broad area. The most effective mitigation plans are based on a development scenario for the entire area, not just for one mine at a time (U.S. Bureau of Land Management, 1986a).

Spatial patterns within a mined area can differ markedly depending upon the scale of the assessment. A minimum of three or four scales is usually adequate for simple analysis and understanding of ecosystem behavior (USDA Forest Service, 1995; Steinhardt and Volk, 2001). For example, at a larger scale are drainage basins produced by a region's climate, lithology, tectonic history, and physiography, which operate during time scales of more than 10,000 years (Petts and Amoros, 1996; Wohl, 2001). A smaller scale may be evaluated for mesohabitats (such as gravel patches, sand bars, or tree roots) that persist during a time scale of 0.01 to 10 years (Petts and Amoros, 1996).

Mining activities can alter the amounts of water and sediment entering rivers or destabilize valley slopes (Wohl, 2001). Taking into account fluvial geomorphic principles in reclaiming disturbed drainage basins and stream channels may promote long-term stability of the land, and a variety of slope aspects and lengths may provide a greater diversity of vegetation (Bugosh, 2002; Wright and White, 2004).

In the early 21st century, some mining companies are considering the environment more holistically, and they are integrating ecological studies with landscape character, historic land use, and local culture. Local identity remains important in rural areas that are faced with urban sprawl. In Europe the norm is to restore the cultural landscape, whereas in North America the norm is to restore pristine landscapes (Society for Ecological Restoration, 2004). Few places on Earth are unaffected by human activity. Natural or wild untouched areas have vanished from most parts of the world today (Krönert and others, 2001). Many Europeans include the capacity for human use in their models of "natural" environments and development. For example, the Dutch view landscapes and culture as interrelated; building construction in existing ecological zones and creation of new wildland environments in urbanized areas are both considered "natural" (Scott, 2002). The Dutch, as have most Europeans, have been living in cities, dealing with the loss of natural habitat, and running out of space for a much longer time than North Americans.

If humans are to be accepted as part of the ecosystem, changes in the appearance of landscapes are inevitable, and if biodiversity is to be a goal, then a forward-looking mining industry probably will welcome citizen participation, understand the complexity of evolutionary processes, and move away from managing single species. For example, forested ecosystems may change slowly owing to long-term drought or more quickly owing to fire and manmade development. We may want to consider what we want from our forests, how to improve forest health, and which land uses to promote or discourage.

\section{The Visual Environment-Measuring Landscape Quality}

Of our six senses, sight is the one that we use the most in our Western culture. Hearing, smell, taste, touch, and balance influence our perceptions of mining, but the visual effect of mining may raise public concerns quickly, especially near residential or, conversely, less developed areas. Visual assessment early in the planning stages may assist in extraction operations fitting within the natural and social environments. Given that mining may disturb the landscape, a mine is best sited where it offers the least amount of contrast and can be subordinated to the natural landscape.

Many visual-assessment methodologies evaluate natural or rural landscapes where recreation or tourism is increasingly important. Most simply, one can evaluate the landscape by a descriptive inventory of its features (called a visual analysis), by compiling viewers' emotional response to or experience of a landscape (called a user analysis), or by combining the two approaches for a more holistic evaluation.

\section{Visual Analysis}

The inventory approach identifies visual elements in a landscape and their interrelationships. On the basis of the character of a given landscape, government agencies may deny permits for a mining operation in a scenic area or a widely visible landscape, or they may remove certain lands from mineral development because the lands contain critical 
wildlife habitat, agricultural lands of importance, or officially designated scenic vistas, backdrops, and views. Natural areas of unique beauty, geology, vegetation, or historical significance may also be excluded. The capacity of a landscape to accommodate change commonly is considered as well as the opportunity for new development.

Aspects of the physical landscape (such as significant geologic features, historic sites, vegetation, rare species, land use) or design elements (such as form, line, color, and texture) may be inventoried, usually by an expert, to help establish a landscape baseline that provides a basis for predicting the potential effects of mining operations. The whole landscape is assumed to be defined and explained by the sum of its parts, and scenic beauty is assumed to be a physical attribute. The visual analysis methodology, the traditional method of choice, is descriptive, versatile, and relatively low cost. This approach, however, fails to take into account the users' or observers' perception of scenic beauty (a perception that may differ from place to place) or economic tradeoffs, and it assumes that landscapes are objects rather than systems. Thus, the method may favor a certain type of landscape and is subjective in the physical attributes selected.

Scenic attractiveness has come to include intangibles (such as scenic vistas, natural quiet, sounds of nature, clear night skies, and human psychological well being) as well as the tangibles (such as unique landform, water, animal species, geologic features, and historic sites) (fig. 24). Indirect effects associated with mineral development (such as new roads, signage, transmission lines) and longer term effects (such as housing that builds up later around a mine site) are of concern but hard to address in detail (Landscape Institute and Institute of Environmental Management and Assessment, 2002).

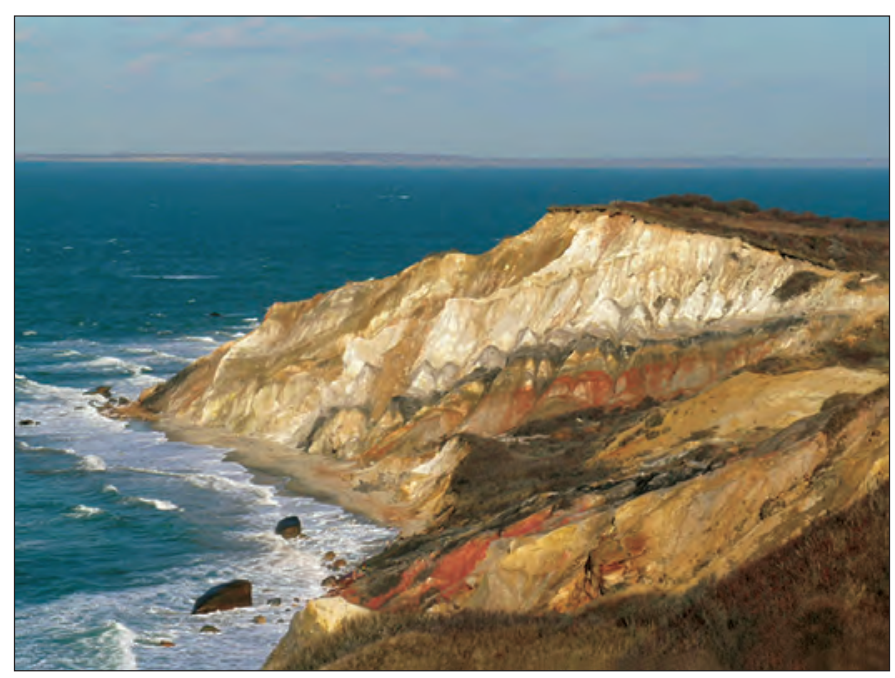

Figure 24. Gay Head Cliffs (now known as the Aquinnah Cliffs), on the western tip of Martha's Vineyard, Mass. The cliffs, a national natural landmark, contain multicolored clays and sands that formed about 100 million years ago. Photograph by B. Arbogast, 2005.
The Natural Resources Management Reference Manual used by the National Park Service (U.S. Department of Interior National Park Service, 2001, p. 2) does not address “*** aesthetics in the context of the built or cultural environment***” but considers viewsheds, photographic visibility, weather data, air quality, sociological studies (to evaluate visitor preferences and aesthetic effects) and ethnographic research (to document the aesthetics, preferences, and concerns of Native American and other communities). Old Man Mountain, on the east side of Rocky Mountain National Park, Colo., is an example of a sacred landscape used for vision quests for more than 3,000 years (Stone, 1999). Increasingly, Federal agencies may be expected to include Native Americans in the consultation process for historic preservation and in construction and development projects in or near Native American lands (Banks, 1999).

A more inclusive understanding of landscape is based on experiential appreciation and what a landscape does rather than just the Western appreciation of scenery for how it looks (Makhzoumi, 2002). The English design philosophy of landscape, so often expressed in the United States as an ideal, includes green grass on a vast scale, irregular form, a concern with form rather than content, and a character of greatness (Jellicoe and Jellicoe, 1987) (fig. 25A). The United States expresses that desire for bigness and green grass with reclamation in arid and semiarid lands that requires water and fertilizer. In contrast, the form of certain Middle Eastern cultural landscapes can express an almost indistinguishable relationship between inside and outside living spaces. "The spaces are mathematically proportioned, human in scale, and in principle imaginatively unconfined" (Jellicoe and Jellicoe, 1987, p. 41) (fig. 25B).

Landscape quality does not refer solely to the physical landscape in front of your eyes. Landscape is also a psychological vision that exists in the mind and may trigger an emotional response. Our past experiences, socioeconomic profile (including factors such as age, ethnic identity, income level, and education), and rapidly changing world view influence our visual values and aesthetic traditions (Zongyu and others, 2002). People in many cultures share a craving for aesthetic satisfaction in order to maintain physical and psychological health (Kellert and Wilson, 1993). This craving includes preferences for nature, water, and mountains (fig. 26); a mix of open landscape and forest; a focal point, distant views to the horizon, and moderate complexity (Zube and others, 1975; Ulrich, 1977, Porteous, 1996).

\section{User Analysis}

The user analysis approach evaluates individual preferences (the observer's or user's point of view), requires surveys, is subjective, assumes that good feelings are produced by a scenic landscape, and relies upon the totality of human experience. Of all landscape assessment methods, psychophysical methods have been subjected to the most rigorous evaluation (Daniel and Vining, 1983). Such models do not classify landscapes but rather predict scenic preference or 

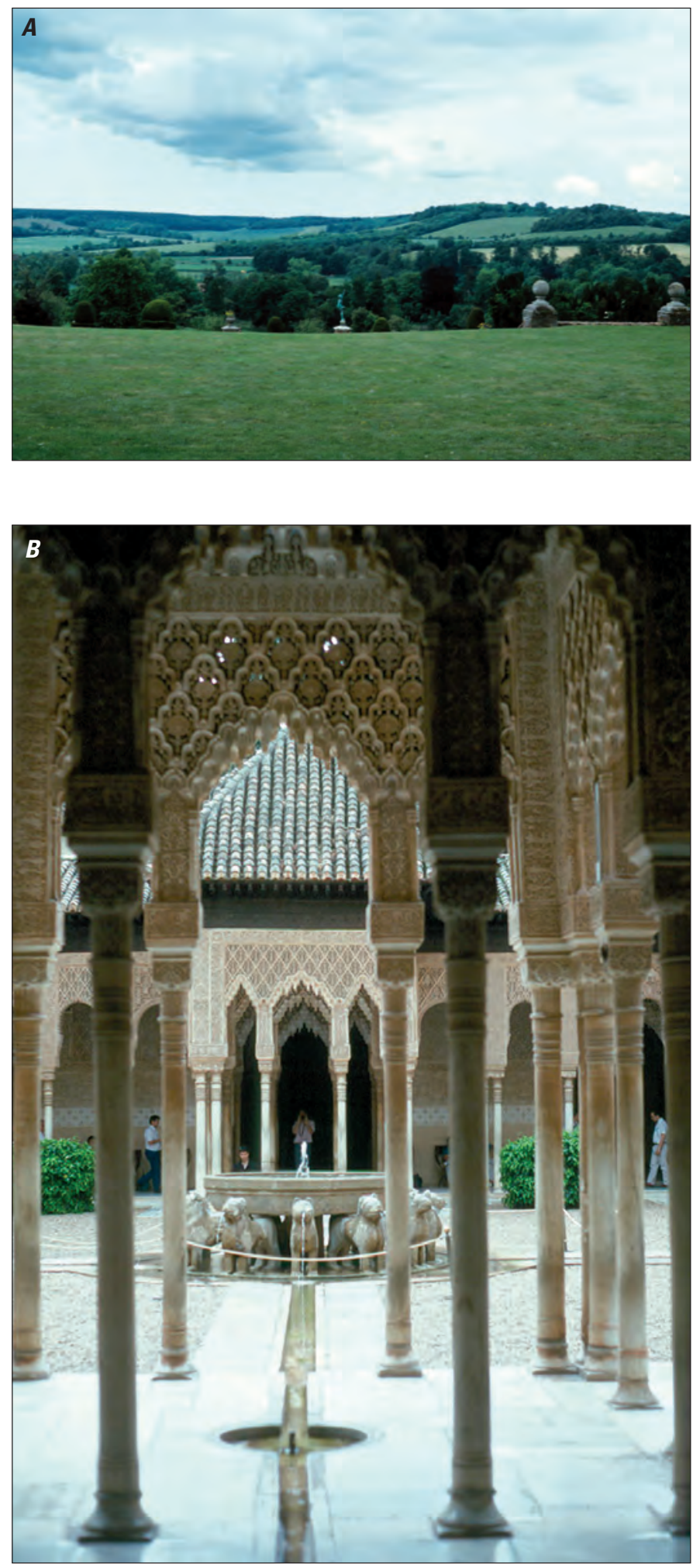

Figure 25. Use of water in two cultures. $A$, Estate lawn in England, where rainfall is plentiful. $B$, Court of the Lions, Alhambra, Spain, where water is scarce. Columns are alabaster, an industrial mineral. Photographs by B. Arbogast.

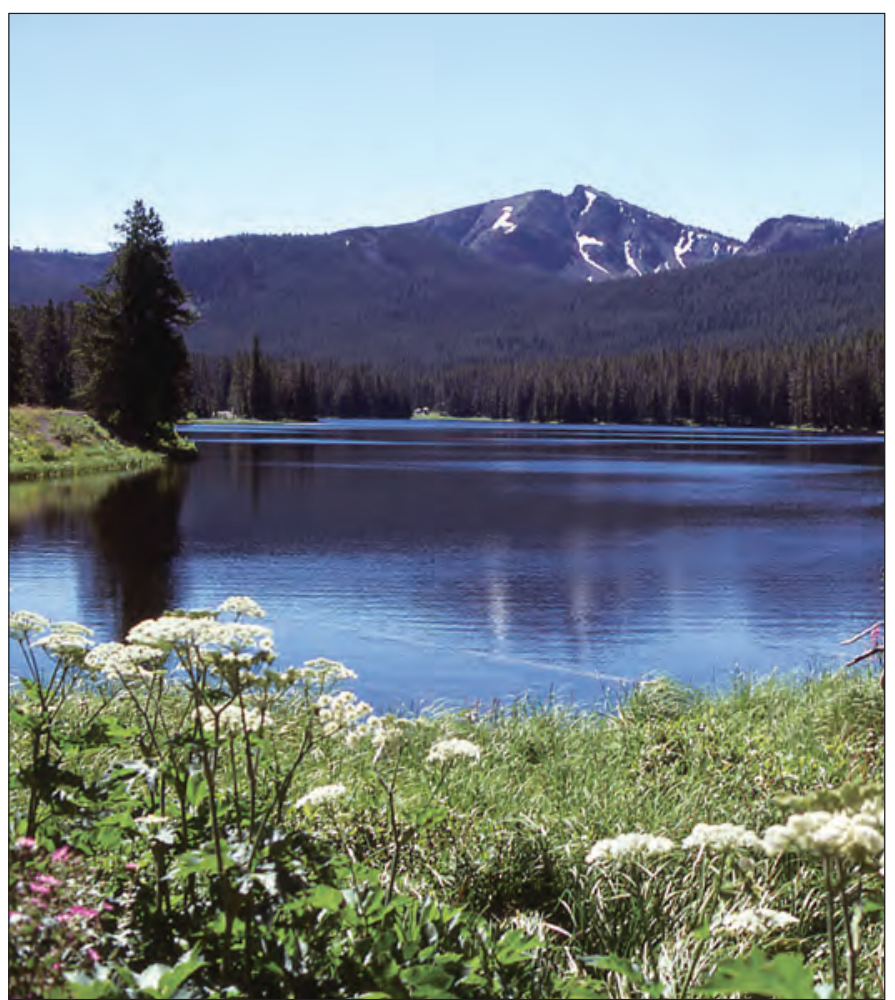

Figure 26. Sylvan Lake, Yellowstone National Park. Courtesy of National Park Service.

visual quality. Psychophysical models are developed specifically for a given landscape type and observer population (Buyhoff and others, 1994). Psychological variables used in determining visual quality (such as legibility, coherence, prospect, drama, and mystery) have been related to physical viewshed properties (such as breadth and depth of view, characteristics of the horizon or skyline, surface shape, and relief) by use of geographic information systems (Baldwin and others, 1996; Meitner and Daniel, 1997).

Discussions, correspondence, public meetings, and workshops - in which these psychological preferences can be expressed-typically use considerable time and money. Survey and questionnaire costs may be lowered and efficiencies increased through the use of the World Wide Web; chat rooms can increase the opportunity for public participation (Wherrett, 2000). Virtual geographic environments are being proposed so that the public can participate in the analysis of spatial data and in environmental planning (Lin and others, 2002). The prototype system allows public participation in visual impact assessment through online, three-dimensional virtual worlds and three-dimensional representations of participants.

Critics point out that people don't necessarily perceive a natural landscape as scenic. For instance, grand landscapes, such as those in Yellowstone National Park, once were favored over dry landscapes such as those in Pawnee or Comanche National Grasslands in northeastern 
Colorado. The grasslands at one time would have been considered a wasteland. Figure 27 demonstrates that it is not always easy to distinguish and appreciate what is the ecologically valuable in contrast to unhealthy disturbed landscapes; determining the physical characteristics of the landscape remains essential (fig. 27). Basic aspects of analysis remain uncertain: the nature of an appropriate sample size or location, and whether the individual rater or the group average is the more appropriate unit of analysis (Zongyu and others, 2002).

Both the visual analysis (or inventory method) and the user analysis (or preference method) have proven effective in assessing natural landscapes, but they are not considered reliable for urban landscapes (Zongyu and others, 2002). The urban landscape can appear chaotic (owing to noise, signage, and traffic), rigid (owing to massive steel, concrete, or glass structures), geometric (owing to the street grid commonly produced by our land survey system), and sterile (owing to insufficient natural landscape). Urban views are commonly linear (along streets or highways) and foreshortened, much as a mine site appears during operation. Wise planning, design, and reclamation can mitigate such visual problems.

\section{USDA Forest Service and Bureau of Land Management Visual Assessment}

Two visual analysis methods developed by Federal agencies are the Visual Resource Management system (U.S. Bureau of Land Management, 1984), and the Scenery Management system (USDA Forest Service, 1995). Both methods attempt to identify and protect visually valuable public lands. Bureau of Land Management and USDA Forest Service manuals or handbooks provide a means of comparing, in a decisionmaking process, the value of scenery with the value of other resources such as forestry, wildlife, recreation, highways, or development such as oil, gas, or wind energy. The U.S. Bureau of Land Management (2001) and USDA Forest Service (1995) incorporate geographic information systems and image processing technologies to improve on existing expert-based descriptive systems. Both systems

- were developed because of conflict between a new land use (such as timber harvesting, energy development, or mineral development) and existing scenic uses;

- treat the visual landscape as a basic resource;

- value diversity and harmony in the landscape;

- assume that natural-appearing landscapes are the most valued and that most people find certain elements (for instance, clear air and clean water, unique and varied wildlife) intrinsic to scenic attractiveness;

- assess landscape integrity or contrast for the amount of deviation in form, line, color, and texture between the existing and proposed landscape;
- assess landscape visibility through key observation points or distance zones; and

- encourage an interdisciplinary approach.

The USDA Forest Service handbook for scenery management "presents a vocabulary for managing scenery and a systematic approach for determining the relative value and importance of scenery in a national forest" (USDA Forest Service, 1995, p. 5). This system identifies landscape character, analyzes existing scenic integrity, and determines inherent scenic attractiveness, landscape visibility, and scenic classes. The process combines user analysis (people's values and expectations) and visual analysis (physical attributes) in the broad context of ecosystem management. This system allows for changes in the natural system and accepts the cultural landscape.

The Bureau of Land Management system inventories visual resources and applies a visual resource contrast-rating tool in the context of a resource management plan for public lands (U.S. Bureau of Land Management, 1986a,b). The Bureau of Land Management visual management objectives are developed through the Resource Management Plan process for all Bureau lands (U.S. Bureau of Land Management, 1984). "To maintain the health of the public lands, the agency is taking a 'big picture' or landscape approach to land management. This promotes both biological diversity on the public lands and sustainable development of their resources" (U.S. Bureau of Land Management, 1997). The Bureau's mandate under the Federal Land Policy and Management Act of 1976 is to manage the public lands for multiple use, while protecting the long-term health of the land.

\section{Other Visual Assessment Methods}

There are other landscape evaluation methods. Ecological models are sensitive to the natural environment and emphasize species of plants and animals and geomorphologic processes. These models assume that all natural landscapes are of scenic beauty; that landscape quality is related to its "naturalness" and its diversity; and that natural landscapes take precedence over manmade structures and cultural landscapes. However, people are not always able to distinguish between natural and cultural landscapes-for instance, landscapes that contain reclaimed mine sites, cleared forests, hedgerows, and canals (Magill, 1992). Observers also tend to base their landscape preferences upon land use rather than beauty (Arthur and others, 1977).

Scotland, England, and Wales have descriptive systems for classifying the countryside on a national scale, and those countries map landscape character and natural zones to aid in landscape protection and management. Their map system allows for a holistic view illustrating the natural and cultural characteristics of the countryside on the basis of biodiversity and landscape without making judgments about their relative worth (Landscape Institute and Institute of Environmental Management and Assessment, 2002). 


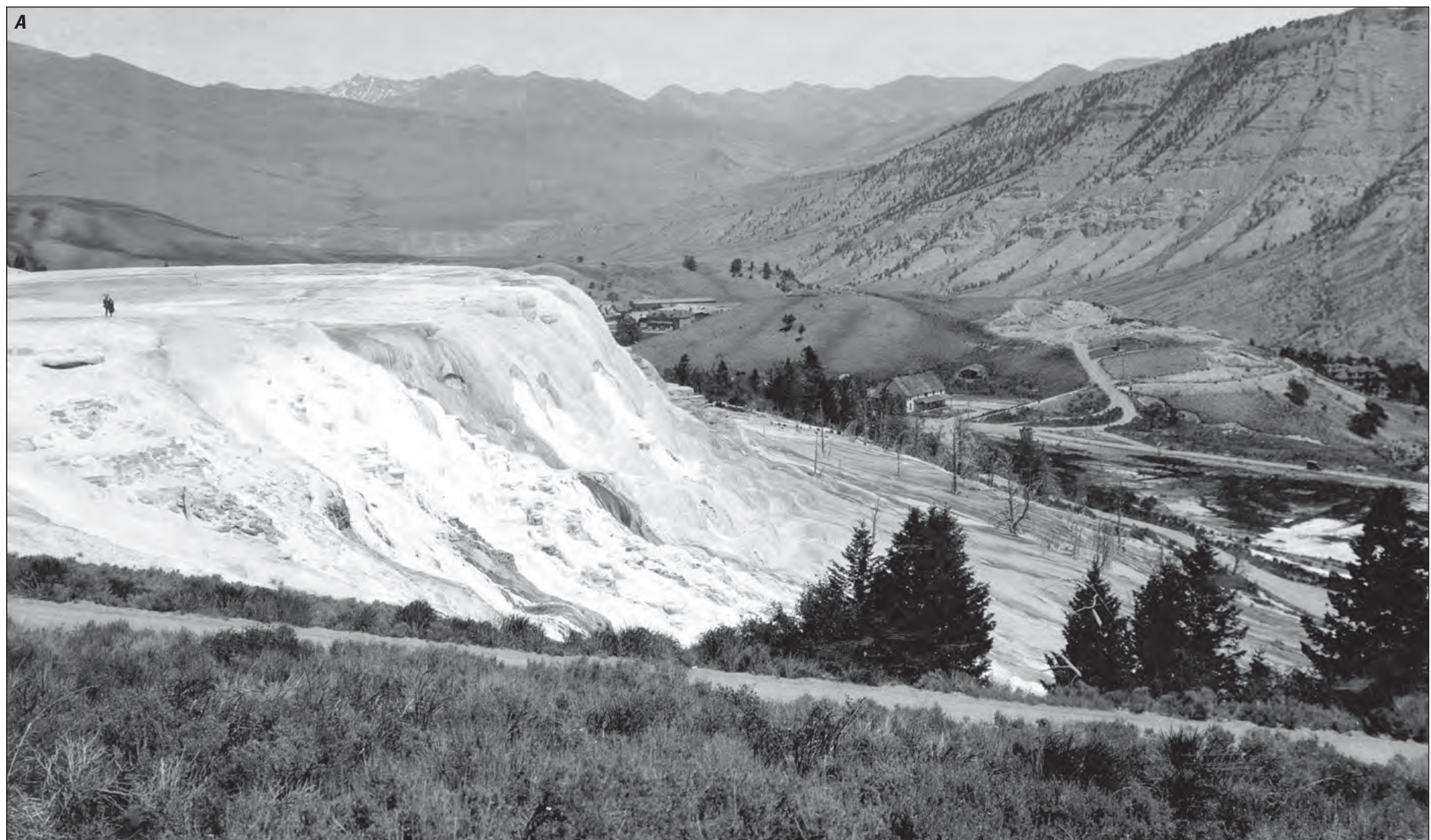

Figure 27. Which features are natural and which manmade? A, Marble terrace at Mammoth Hot Springs, Yellowstone National Park, Wyo., 1922. Photograph by W.C. Alden. Courtesy of USGS Photographic Library. 


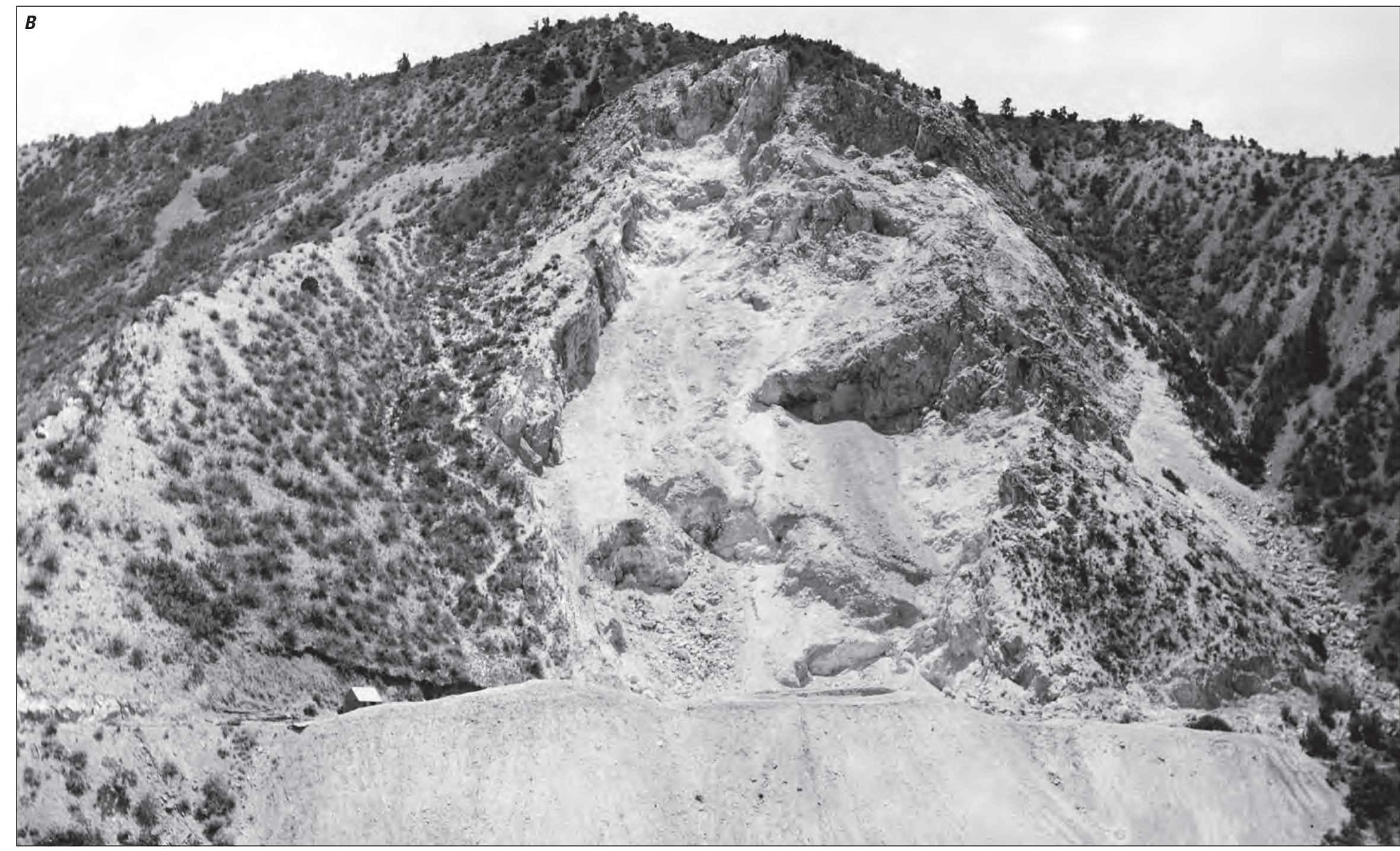

Figure 27. (continued) Which features are natural and which manmade? B, Gypsum quarry and mill, Nephi County, Utah. Photograph by E.F. Burchard. Courtesy of USGS Photographic Library. 

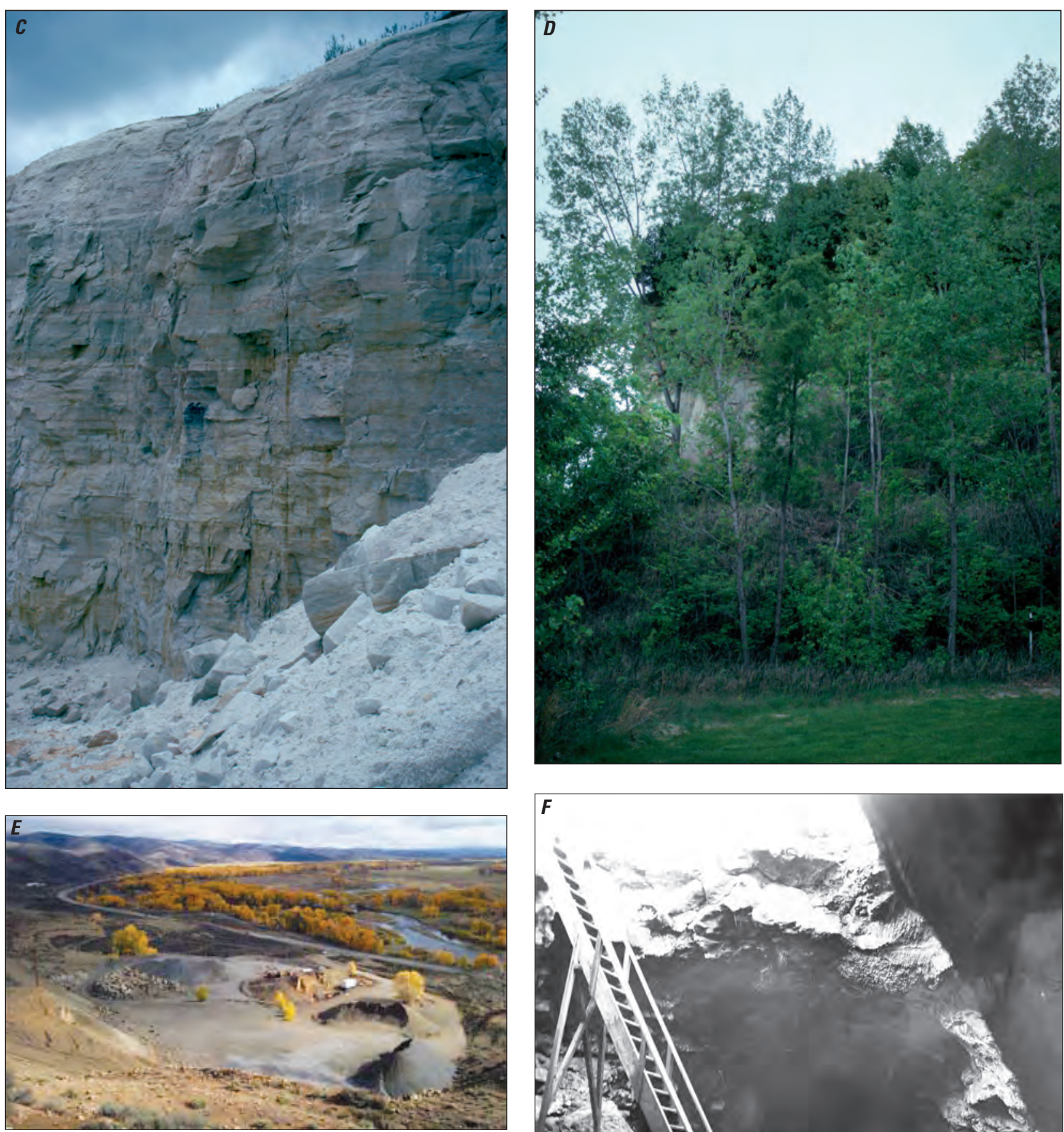

Figure 27. Which features are natural and which manmade? $C$, Cut rock slope with edges in silica mine, Pacific, Mo. D, Similar view, silica mine, after reclamation. Photographs $C$ and $D$ by B. Arbogast. $E$, Aggregate mining operation along the Gunnison River at Curecanti National Recreation Area, Colo. Courtesy of National Park Service. $F$, Great Owl lava tunnel in basalt flow, Craters of the Moon National Monument, Butte County, Idaho, 1952. Photograph by H.R. Cornwall. Courtesy of USGS Photographic Library.

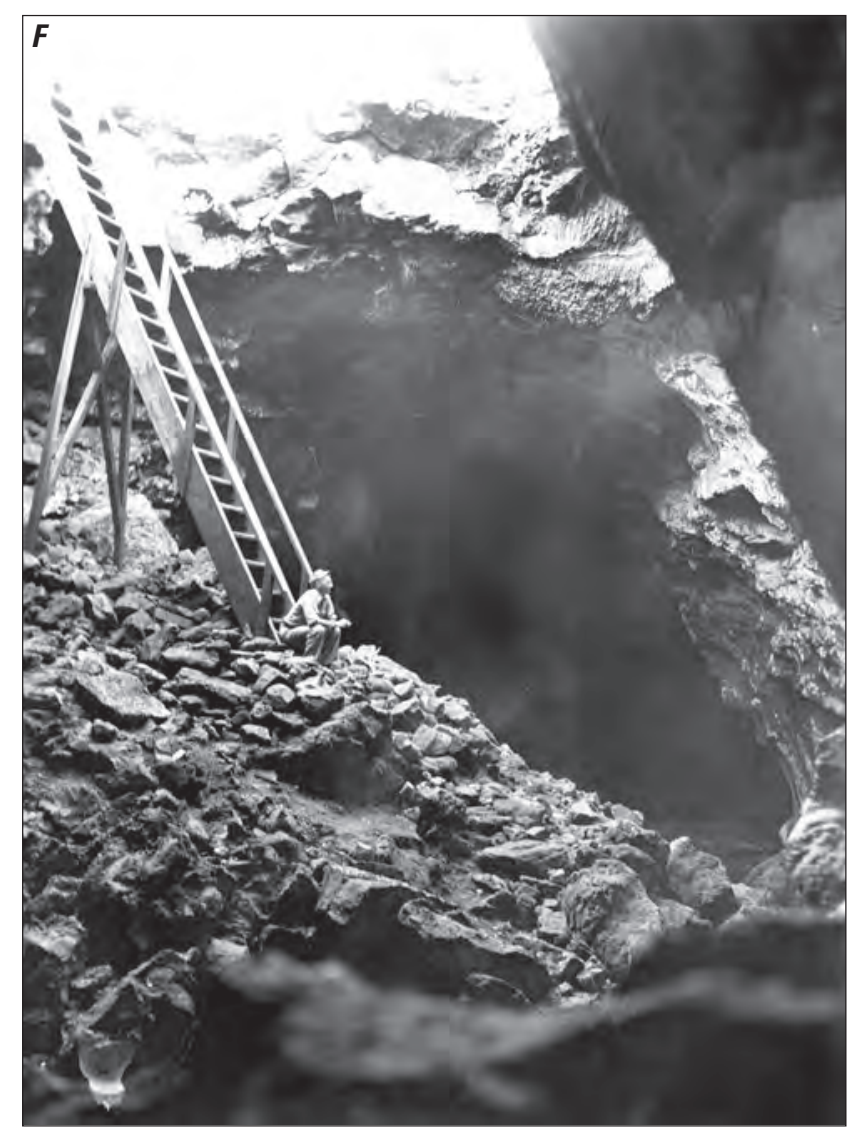


An interdisciplinary approach is recognized as the best approach in landscape evaluation. That means including the technical engineering aspects of mining development when one assesses a landscape's ability to absorb change and treating the landscape as a complex system rather than an object. The USDA Forest Service requires independent audits of forest plans, using a process that it says accounts for changing forest conditions while emphasizing science and public involvement. Mining development has come a long way since Georgius Agricola (1556) published the first Western manual of mining techniques (fig. 28).

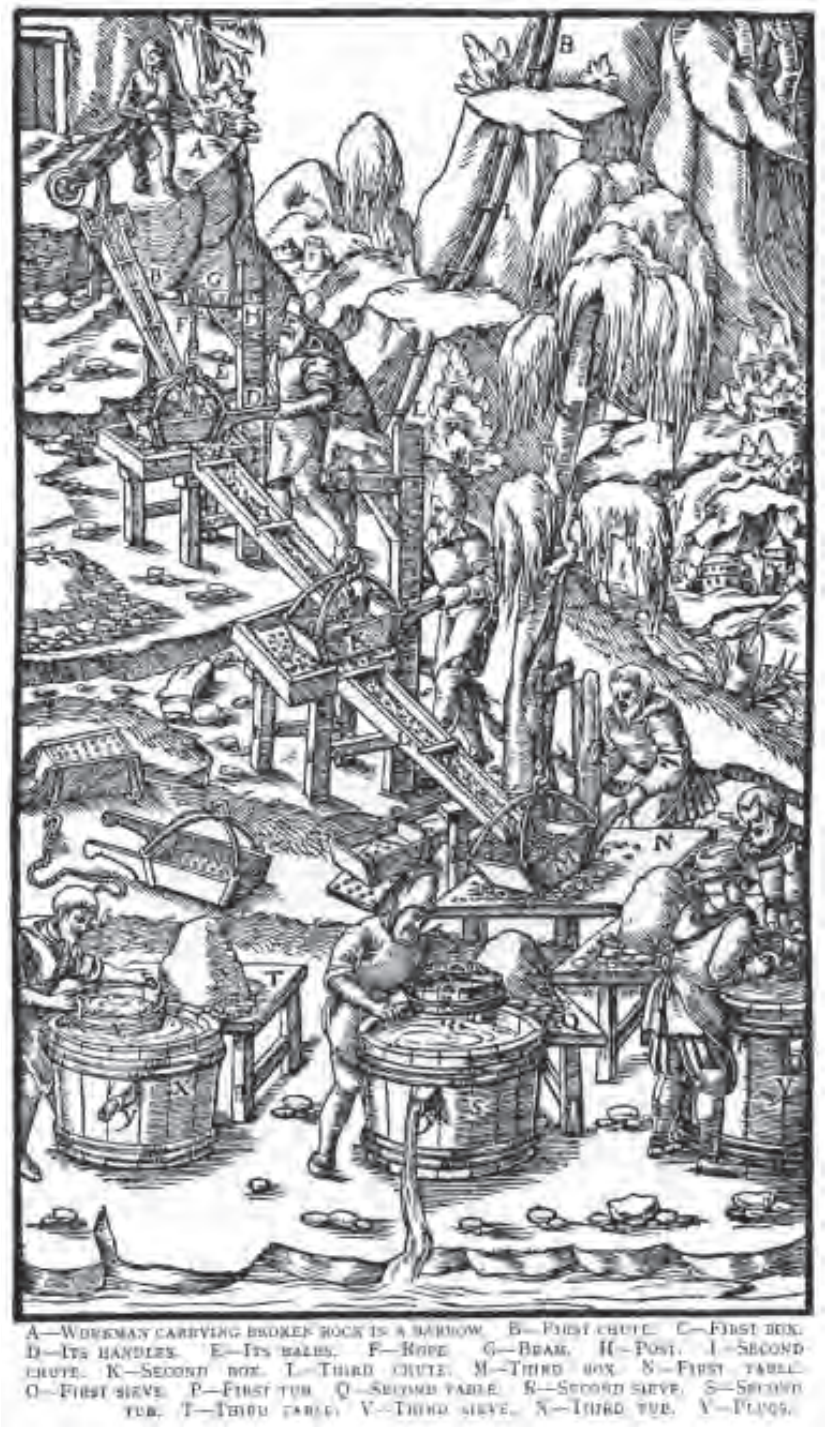

Figure 28. Wood block from Georgius Agricola's “De Re Metallica" (1556) illustrates mineral beneficiation during the 1500s. Courtesy of Stephen Henley. Image downloaded at URL http://www.mining-heritage.com

\section{The Socioeconomic Environment-Efficiency, Equity, and Acceptability}

Our Western industrialized society consumes natural resources in order to build and maintain our manmade environment and indeed our civilization. However, global patterns of production and consumption are uneven (United Nations, 2003b) and, in addition, the mining industry today tries to avoid the boom-and-bust character of past mining operations. More weight is given in mineral investigations to the concept of societal needs (such as public health or the costs and benefits of land-use alternatives), risk assessment, and land values (the effect of mineral production on price per acre and the secondary value of the land after extraction) (Moss, 1977). The public weighs the value of mineral development, whether an immediate need for mineral resources that lie within a national forest or the regional needs of large cities, against other considerations. Courts have upheld that considerations of economic cost and technical feasibility are secondary to considerations of public health (Moss, 1977). Mineral industries are required to ensure the health and safety of their employees and of the local community.

Beliefs about mining are quite susceptible to change on the basis of new information (Bingham, 2000). When the fears of a community about to become neighbors with a mining operation and the importance of mineral resources in daily life are both acknowledged and understood, communication between the public welfare and industry may progress. "Mine site development is often responsible for significant changes in the local social and economic conditions in an area" (Robertson and Shaw, 2004, p. 7). Multiple accounts analysis has been used to weigh the costs and benefits of a new mine in terms of the project's technical, economic, environmental, and socioeconomic accounts (Shaw and others, 2001), sustainability value, aesthetics, stability, and safety (Robertson and Shaw, 2004). The mining industry in Colorado (excluding oil and gas production) contributed about $\$ 8$ billion to the State's economy both directly and indirectly in 2008, and miners are the highest paid industrial workers in Colorado—average annual earnings in 2008 were \$77,920 (Colorado Mining Association, 2008).

Marketing factors play into mining decisions. Natural components of the ore that may be considered contaminants by potential buyers and transportation costs can increase production and market costs enough to eliminate a mining operation. Proximity to rail lines or waterways able to haul bulky material with a low unit value can improve the overall economics of a site. Investment in United States mining operations is falling as the nation's dependence on foreign minerals is rising, and the United States already imports 100 percent of 16 major minerals (U.S. Geological Survey, 2004; Western Governors' Association, 2010). Two of those commodities are the industrial minerals fluorspar and sheet mica, both of which have been mined in Colorado.

Land itself can be viewed as fixed and taxable, an input for production, space for amenities, and as an asset (Xu and others, 1993). The demand for amenities such as scenery, 
recreation, wildlife habitat, and open space is expected to grow as populations continue to migrate into less urban areas (Bastian and others, 2002). The Rocky Mountain region has a "strong public expectation for 'wilderness experience"” (USDA Forest Service, 2001, p. 165) and access to mountain climbing, backpacking, hiking, and bike trails. Sequential land use is an approach that takes into account the undeveloped aggregate resource and allows redevelopment only after the resource has been extracted. Mined lands near metropolitan areas may be redeveloped for residential, commercial, industrial, recreational (such as fishing, boating, swimming, and hiking), or water storage uses, and that land can be sold for a higher price than paid when the land was originally acquired for mining (Fong, 2005). In the Denver metropolitan area, for example, the city of Aurora offered to pay \$17 million to the Central Colorado Water Conservancy District for a gravel pit near Brighton, which will be used for a new reservoir with a capacity of just more than 1 billion gallons of water (Fong, 2005). The higher resale value of depleted sand and gravel mining sites, along with more efficient mining and processing equipment and larger operating units, has been instrumental in maintaining adequate production of sand and gravel (Goldman, 1994).

Pricing a scenic view is difficult, but attempts have been made to do so by use of the following methods (Macaulay Land Use Research Institute, 2005):

- Hedonic price method-Measures people's willingness to pay to live in a particular type of landscape

- Travel cost method—Asks visitors to a site questions about their journey, costs incurred, and sociodemographic characteristics

- Contingent valuation techniques-Estimates dollar value on the basis of landscape component scores and public-preference techniques

- Willingness-to-pay studies-Attempts to value the benefits which visitors and residents might derive from landscapes today or in the future.

Cultural, political, and moral points of view all affect the balance between conservation and resource development. (Bennett, 1993). Traditional economics may not have taken into account public concern over aesthetics or clean air and water, but today doing so is the norm. Ecological economics recognizes economics as part of the global ecosystem; sustainability, distribution, and allocation are key issues (Daly and Farley, 2004). The supply of mineral resources is finite, and the supply that is of sufficient quality and extractable is even more limited. "At a given point in time $* * *$ we can think of mineral resources as rival goods within a generation, but as partially nonrival between [future] generations, depending on how much is wasted and recycled. $* * *$ we could not sustain existing populations or levels of economic production in the absence of these minerals" (Daly and Farley, 2004, p. 86-87).
Sustainability concepts are being applied to mineral resources in many countries of the world at local, regional, and national levels, and from the perspectives of governments, citizens, and industry. Ecosystems have been managed for mineral resources in the past, but community and industry planners, when making decisions, now consider values in addition to production and consumption. Taking environmental issues into account means addressing the inherent value of species diversity and ecosystem processes. Sustainability includes reusing and recycling mineral materials and planning for cleanup and reclamation of the mine site. The costs and benefits of mining and reclamation are likely to become more quantified and scrutinized as conflicts about land use and demand for industrial minerals continue.

\section{Reclamation and Postmining Use}

Reclamation of disturbed sites is a requirement after completion of exploration and mining (U.S. Bureau of Land Management, 1996). Reclamation in the context of mining has a variety of definitions:

- Avoiding or correcting damage to the lands and waters of the mine site (also termed mitigation)

- Making the surface-mined landscape productive (sometimes called rehabilitation)

- Returning the mined land to a beneficial use

- Making the mined land visually attractive.

In North America, reclamation also includes public safety, terrain stabilization, aesthetic improvement, and revegetation (Society for Ecological Restoration, 2004). Reclamation is a broad term that begins with minimizing the effects of exploration and extends to extraction, mineral processing, site decommissioning, and postmining land use (fig. 29). It also means considering community wants and needs. On forest lands, structures and roads should not disturb ecological integrity and should respect the landscape's character (USDA Forest Service, 2001). Reclamation of mined lands on national forest lands, which is required by the Forest Service at the operator's expense, has created ecological niches, wildlife openings, wildlife ponds, dispersed group camping, and even a shooting range. Effective reclamation aims for proper hydrologic requirements, the best ecologic conditions for the land-use objectives, and the most pleasing aesthetic experience for the viewer (National Academy of Sciences, 1974).

Restoration in the early 21st century is more ecological and includes the reestablishment of preexisting native habitat and blending the landscape into the greater surrounding community. People tend to be more concerned with safety or revegetation than with restoration of sound ecosystems (Tapsell, 1995). It is important to reclaim the land with respect to its geomorphology and natural processes. Land so reclaimed will have long-term stability, lower long-term costs, greater diversity, and visual harmony (Trimble, 1997; Bugosh, 2002). Reclamation and ecological restoration projects that anticipate 

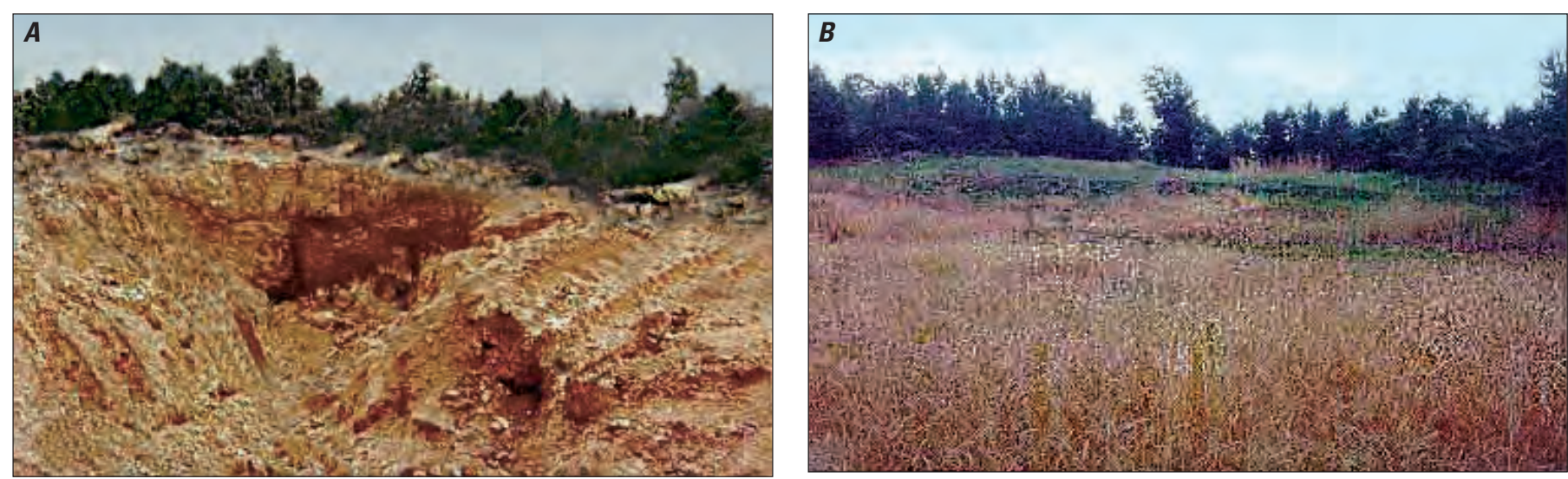

Figure 29. Mine site restored to approximate its original state. A, A quartz crystal mine, Womble Ranger District, Ouachita National Forest, Ark. B, Same view approximately three years after reclamation. Courtesy of J.C. Nichols, Ouachita National Forest.

unwanted effects and work with natural processes are more likely to be successful from a social, economic, and environmental objective (Trimble, 1997; Bugosh, 2002).

Projects successful in the long run aim for an ecosystem that is restored to a historic trajectory (that is, one that describes the broad developmental pathway of an ecosystem through time), not a particular narrow and specific historic state (Society for Ecological Restoration, 2004; Winterhalder and others, 2004). Determining the historic trajectory of a disturbed site may be difficult in practice owing to the highly complex nature of the entire ecosystem (Winterhalder and others, 2004). One thing that most planners and scientists agree on is that reclamation planning is best begun well before excavation can start.

Mining operations may follow any of four reclamation strategies: progressive, segmental, interim, or postmining (Norman and Lingley, 1992) depending on the site's location, type of mineral resource, and State or local laws. Progressive reclamation immediately follows the removal of overburden and the mined material. It is preferred by the public but may be wasteful or impractical for those operations that blend compositions or grain sizes (Norman and Lingley, 1992). Segmental reclamation follows the removal of minerals in designated sections of the mine. It is cost efficient, establishes final slopes as part of the mining operation, and works well in homogenous deposits (fig. 30). Interim reclamation meets temporary goals in order to stabilize disturbed areas with fastgrowing grasses or legumes. Postmining reclamation does not begin until the entire mine has been exhausted. Postmining reclamation may lead to deterioration of soils and take longer to revegetate, and bond liability may be high.

The final land use of a mine site is influenced by surface topography, elevation above or below the water table, proximity to other development, and needs of the local population. Plans for reclaiming mine sites generally use at least one of nine design approaches (Arbogast and others, 2000): natural, camouflage, restoration, rehabilitation, mitigation, renewable, education, art, and integration. The best-managed reclamation operations commonly incorporate several design approaches such as camouflage, mitigation, renewable, and education. Some highly successful mine reclamation projects achieve uses that the public may not associate with mined-out land.

Visitors to national forests expect to see landscapes that appear natural (USDA Forest Service, 2001). Natural reclamation allows nature to reclaim the mine site with no or little human influence. At a minimum, the topography is restored to blend with surrounding landforms and at least $30 \mathrm{~cm}$ (12 in.) of topsoil is replaced within 5 years. To protect farmland soils, the subsoil may be salvaged to a depth of $1.2 \mathrm{~m}$ (4 ft) (Wright and White, 2004). Preferably, when soil is removed from an active area of the mine, it is immediately spread over graded overburden (Wright and White, 2004). If necessary, the topsoil is stored in stockpiles no more than $1 \mathrm{~m}$ (3.2 ft) high to retain the maximum amount of microbial (mycorrhizae) activity (Norman and Lingley, 1992; Gratzfeld, 2003). Mycorrhizae are formed by a symbiotic

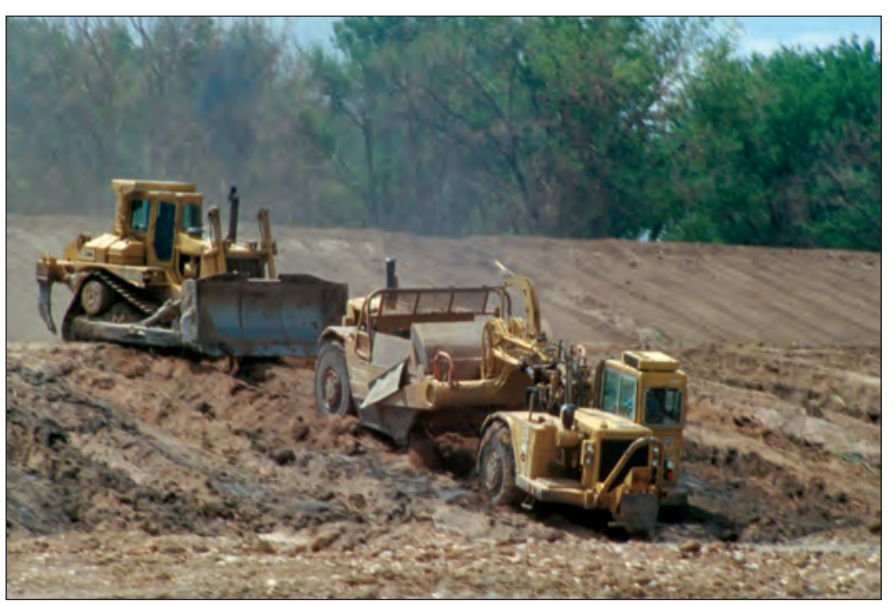

Figure 30. Reclamation work at the Howe pit, north of Denver, Colo. Such work requires moving earth. Photograph by B. Arbogast. 
association of fungus with a root or rhizome of a higher plant (Bates and Jackson, 1987). Because mycorrhizae spores are distributed by wind, most reclaimed sites are inoculated naturally within a year (Wright and White, 2004). Inoculua for small sites can also be collected from nearby soil and fine roots. In some instances, topsoil may not be replaced in order to encourage the emergence of plants that don't germinate in topsoil, such as piñon pine and mountain mahogany (Mineral Information Institute, 2004). Rocks and boulders can be salvaged in order to mimic the surroundings, diversify habitat, and reduce surface soil erosion.

Camouflage is a superficial and immediate treatment of the landscape to hide the operation, usually around the perimeter of the site. Buffer zones, reclamation setbacks, rock outcrops, natural topography, fences, vegetation, and earth berms may be used to screen views (fig. 31). Slightly darker color schemes that use colors in the local landscape may reduce the prominence of structures such as water towers or fuel storage tanks. Technology can help reduce the contrast between the existing landscape and mine surfaces. For example, microorganisms can be sprayed on exposed limestone to more quickly start natural ecological processes (for example, weathering) (Courtney, 2001).

A restoration approach has been used in landscapes as varied as prairie, woodland, orchards, farmland, stream and riparian, and beach. Former quarries and pits have been restored to habitats of high biodiversity value that shelter threatened or endangered species. Many sand and gravel quarries support a large number of breeding water birds (English Nature and others, 1999). Butterflies, bats, frogs, and toads are among the wildlife that can be attracted to a former quarry (fig. 32). A bentonite mine operated by Wyo Ben Inc. in the Big Horn Basin, Wyo., was the recipient of

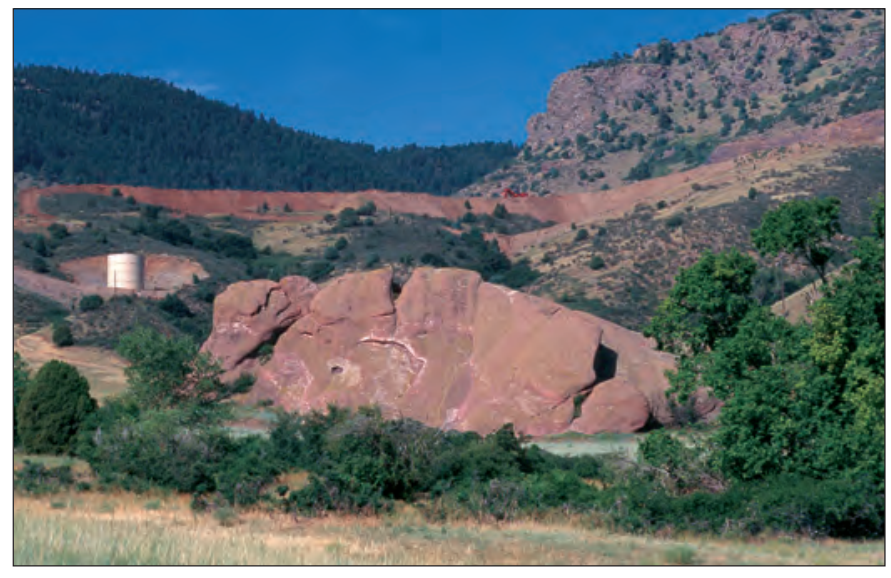

Figure 31. Visual screens and buffers help to camouflage a mining operation. Topography and an earth berm conceal an aggregate mining and production facility south of Morrison, Colo. Painting the storage tank in the left middle ground an earth color would reduce the visual contrast. Photograph by B. Arbogast.
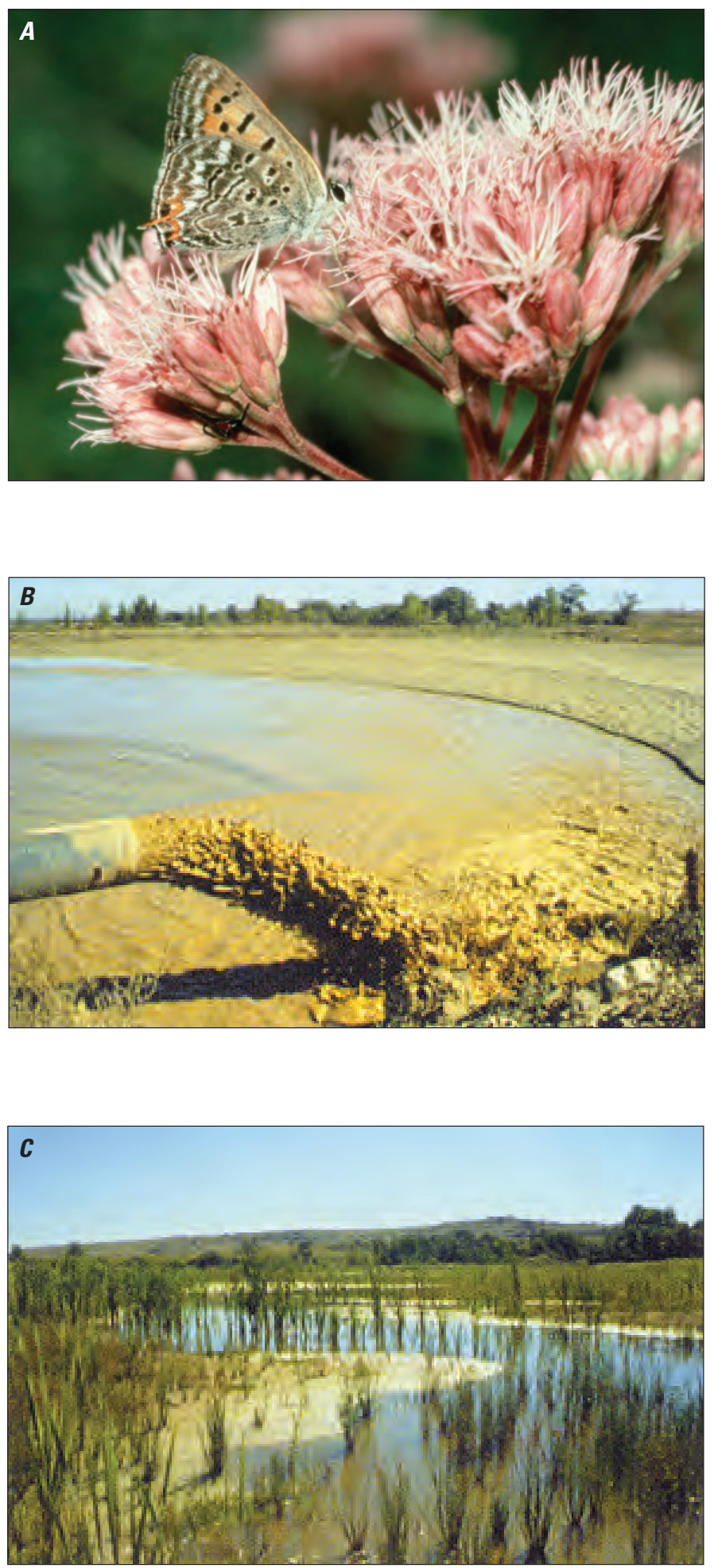

Figure 32. Postmining land restoration in Colorado. A, Butterfly at South Platte Park, near Denver, formerly mined for aggregate. Photograph by Bill Bevington. Courtesy of South Suburban Park and Recreation District, Littleton, Colo. $B$, Settling ponds that once were part of a gravel pit near Boulder. $C$, The same pit, now called the Marshall Pit Wetland, after reclamation. Photographs $B$ and $C$ courtesy of Mineral Information Institute. 
the 1999 Wyoming Game and Fish Department Mine Reclamation and Wildlife Stewardship Award (Mineral Information Institute, 2004).

Mine sites in urban areas tend to be rehabilitated. The exhausted mine site may be used for public amenities such as amphitheatres, botanic gardens, swimming areas, or soccer and baseball fields; hiking, bicycle, and horse trails; or golf courses (fig. 33). An operating sand and gravel pit in Moab, Utah, is slated to become a community pit ("collect the aggregate yourself") as part of the reclamation plan. The pit will continue to provide sand and gravel for the public once commercial extraction has ceased. A jail, housing, and industrial development occupy former clay and shale quarries in West Virginia.

When a mine site requires extensive repair (usually because it has been abandoned) or scientific input to protect the environment from degradation, a mitigation approach may be required. Sand and gravel quarries have improved the value of rivers for biodiversity by widening the river or regrading its banks (English Nature and others, 1999). Copeland Sand and Gravel of Grants Pass, Ore., which had been mining aggregate from pits adjacent to the Applegate River, took advantage of a 1997 flood. The flood redeposited tons of river rock and changed the course of the Applegate River. The company worked with the Oregon Department of Fish and Wildlife and Department of Geology and Mineral Industries to enhance fish habitat and decrease erosion along the river while excavating the aggregate (Mineral Information Institute, 2004). Gravel with smooth pebbles is also used to line ponds at fish hatcheries so that spawning fish aren't injured when laying their eggs (Keller and Widmann, 2002).

Reclaiming land in a renewable fashion implies sustainability and ecological management. Reducing the amount of minerals removed from the land and efficient use of the appropriate material for a given manufactured product extend the availability of mineral resources. Mine sites have been used for composting, forestry, groundwater recharge, wastewater treatment, and recycling of glass, concrete, and macadam.

Educative reclamation projects include nature trails, boardwalks, viewing areas, and signage that explain the area's natural history and historical significance (fig. 34). In an educative approach, mining information is communicated through outreach so citizens can make informed choices about future land use and learn about environmental responsibility.

An artistic approach celebrates the site as a work of beauty and unique experiences; the earth becomes outdoor sculpture (fig. 35). Projects may be ephemeral in nature and associated with natural processes and geology.

Finally, an integrated approach combines art and science, fulfilling aesthetic, utilitarian, recreational, cultural, and ecological needs (fig. 36). Such works can repair the damage done by past engineering works. With an increased demand for multifunctional space, the integrated design approach is being increasingly used. The Owl Canyon Quarry Project is on the eastern slope of the Rocky Mountains in northern Colorado, at more than $1,800 \mathrm{~m}(6,000 \mathrm{ft})$ in elevation. The design
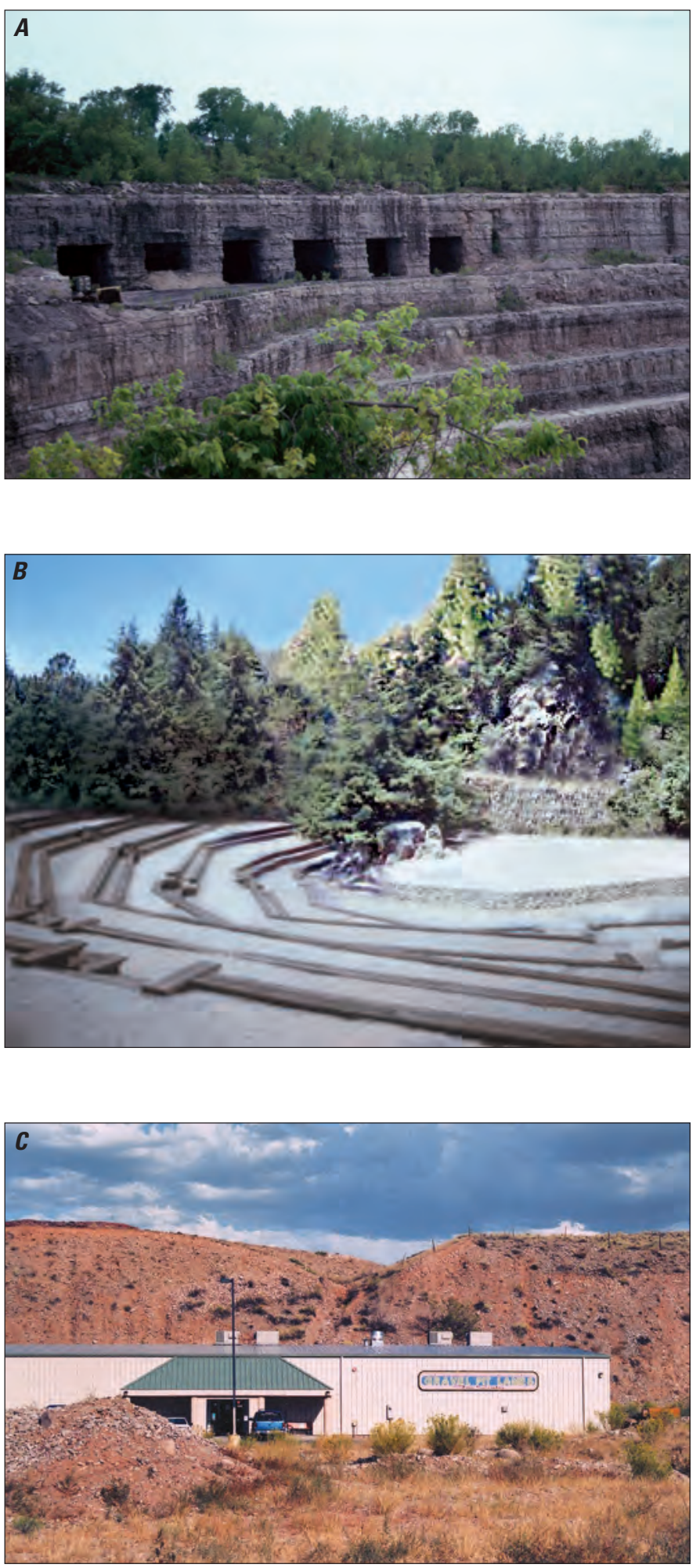

Figure 33. Community needs controlled how these mined lands were reclaimed. $A$, A future underground storage facility at Bussen's quarry near St. Louis, Mo., 2002. B, An amphitheater built within a stone quarry, Santa Cruz University campus, California. Courtesy of Mineral Information Institute. C, Bowling alley, the Gravel Pit Lanes, built in a former sand and gravel pit, Moab, Utah, 2005. Photographs $A$ and $C$ by B. Arbogast. 

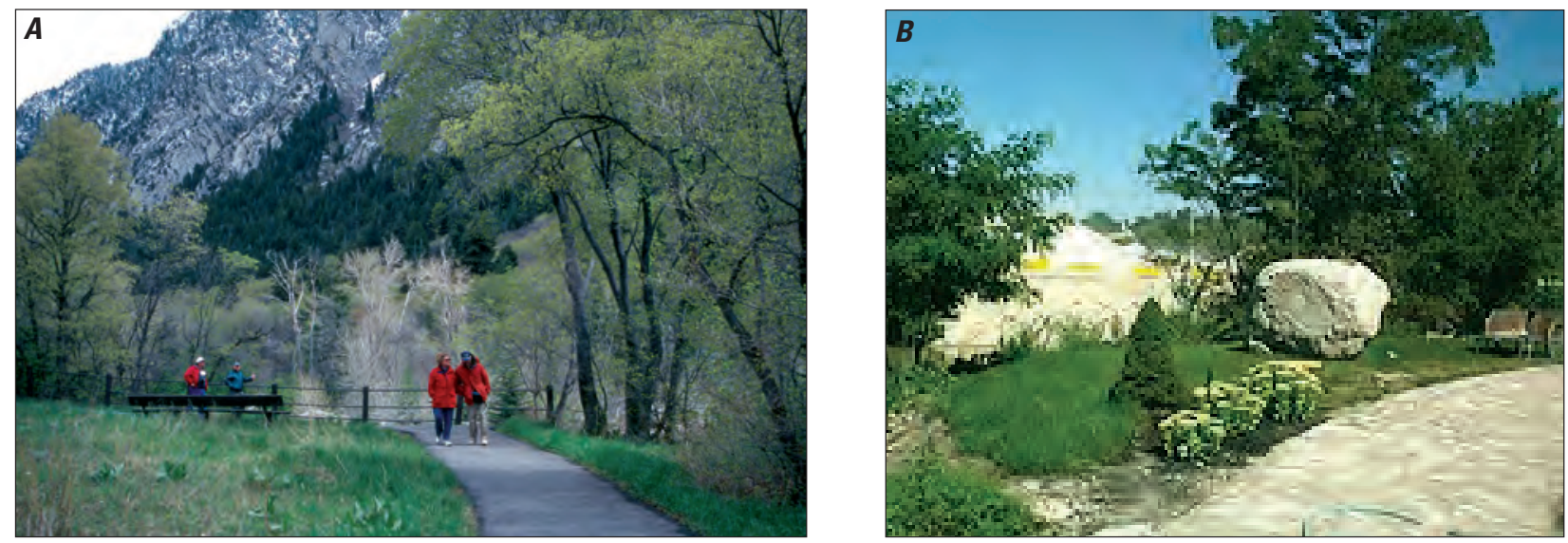

Figure 34. Two quarries opened to the public that educate the public about mining. $A$, Temple Quarry nature trail, near Little Cottonwood Canyon, southeast of Salt Lake City, Utah. The granite from this former granite quarry was used to build the Salt Lake Temple. Photograph by B. Arbogast, 1999. B, Park-like setting serves as staging area for open houses and quarry tours, Fox River Stone Company, South Elgin, III. The active quarry is visible in the background. Courtesy of Mineral Information Institute.
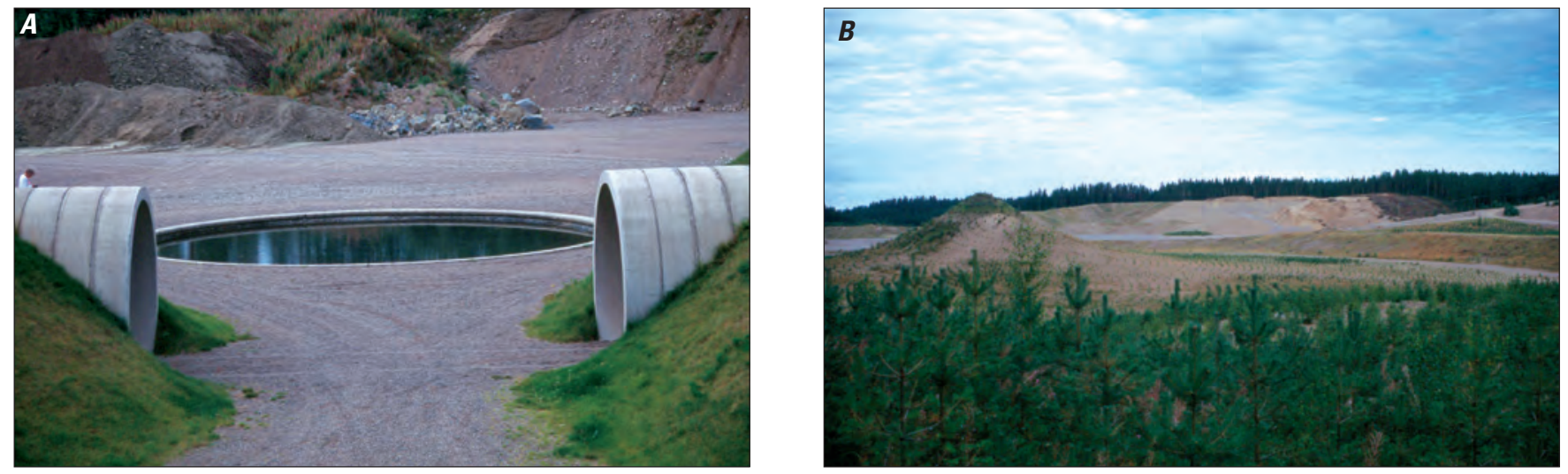

Figure 35. Two large reclamation art works have a similarity to art minimalism. Earth works as land art are primarily concerned with the environment. $A$, Nancy Holt's “Up and Under" and $B$, Agnes Denes' “Tree Mountain" projects at gravel pits near Pinsi, Finland. At Tree Mountain, 10,000 trees were planted by 10,000 people. The land is protected and will be maintained for 400 years. Photographs by B. Arbogast, 2001.
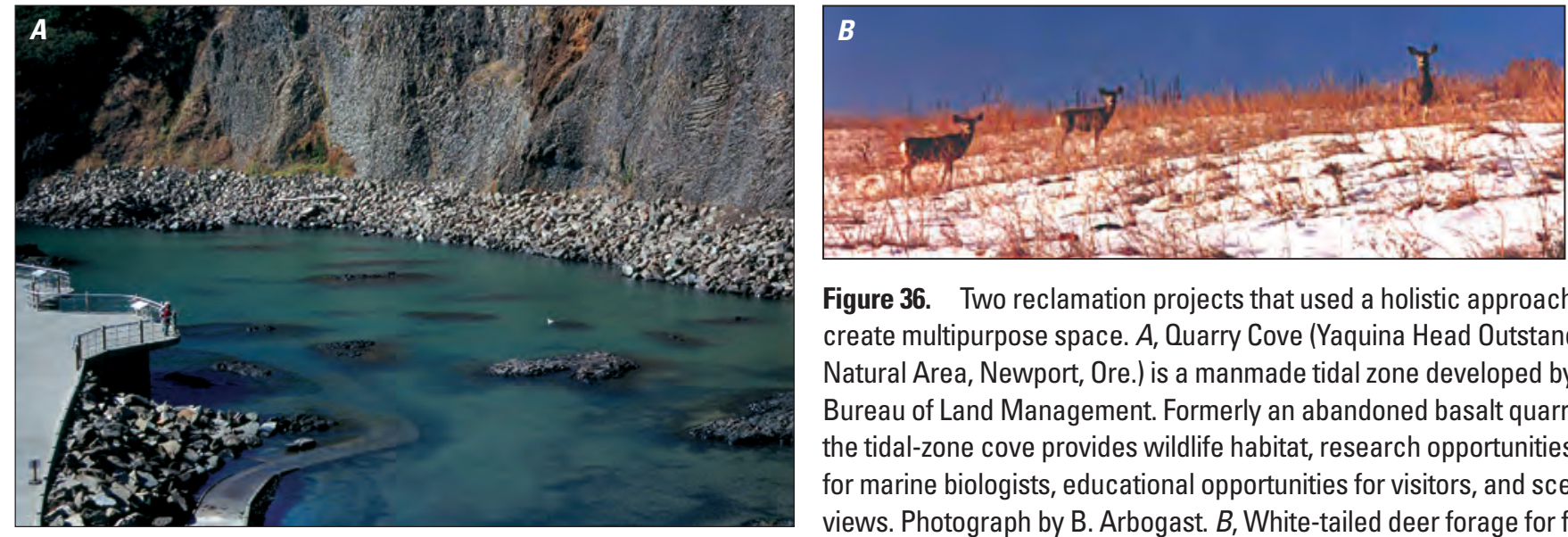

Figure 36. Two reclamation projects that used a holistic approach to create multipurpose space. A, Quarry Cove (Yaquina Head Outstanding Natural Area, Newport, Ore.) is a manmade tidal zone developed by the Bureau of Land Management. Formerly an abandoned basalt quarry, the tidal-zone cove provides wildlife habitat, research opportunities for marine biologists, educational opportunities for visitors, and scenic views. Photograph by $B$. Arbogast. $B$, White-tailed deer forage for food on a newly reclaimed area of the Owl Canyon Quarry, Colo. The diverse landscape accommodates both grazing and wildlife interests. Courtesy of Mineral Information Institute. 
accommodates grazing and wildlife interests, a variety of landscaped slopes, some intact highwall faces to attract raptors, and small canyons and talus slopes to resemble the existing hogback formations (Mineral Information Institute, 2004).

In Colorado, many former sand and gravel pits have become water reservoirs, recreational lakes for fishing and boating, wildlife protection areas; others assume "hidden" uses. Hidden landscapes are reclamation projects that people may not realize were once active mines. Former pits and quarries across the country are now in use as an amphitheater, golf course, shopping center, residential housing area, farmland, nature center, riparian habitat, and tidal pool.

Practical, economic, environmentally and culturally sensitive reclamation plans commonly are flexible and emphasize process (for example, sustainability, maintenance issues, or monitoring of best management practices). Opportunities exist for mine sites to create habitat and improve biodiversity, support educational and recreational use, fulfill community needs, and provide industrial mineral products for society.

As anthropomorphic agents, humans can work to make landscapes sustainable, diverse, and profitable, and we can choose whether the landscape appears "natural" or "manmade" (fig. 37).

\section{Colorado Industrial Minerals- Occurrence, Use in Colorado, Mining, and Production}

\section{Introduction}

The geology of Colorado is conducive to the occurrence of numerous types of industrial minerals. The State contains industrial minerals associated with igneous, metamorphic, and sedimentary rocks. Some common industrial minerals, such as sand and gravel, crushed stone, and dimension stone, continue to be fundamental to the economy of the State. Others, such as fluorspar and nahcolite, once formidable commodities in the State, are no longer produced, while large deposits of titanium have never been produced.

\section{Clays and Shale}

Clay has been used in sun-dried bricks for possibly 10,000 years and in earthenware for at least 9,000 years (Christie and others, 2001b). The term derives from the Old English clāeg, akin to the Latin glus or glue (MerriamWebster, 2009).

Clays and clay minerals are found mainly on or near the surface of the Earth (fig. 38). The term "clay" has two meanings. In its size sense, clay is any very fine grained material (grains having a diameter less than 1/256 millimeters (mm) or 4 micrometers $(\mu \mathrm{m})$ or 0.00016 in., the upper size limit of particles that can show colloidal properties (Bates and Jackson,
1987)). In its compositional sense, clays are minerals rich in alumina $\left(\mathrm{Al}_{2} \mathrm{O}_{3}\right)$, silica $\left(\mathrm{SiO}_{2}\right)$, and water in various combinations (U.S. Environmental Protection Agency, 1995c). Clay minerals commonly are clay sized. What is commonly called "clay" may be a mixture of fine-grained clay minerals (hydrous aluminum silicates) and clay-sized grains of quartz or minerals that contain carbonate or metal oxides (Foley, 1999).
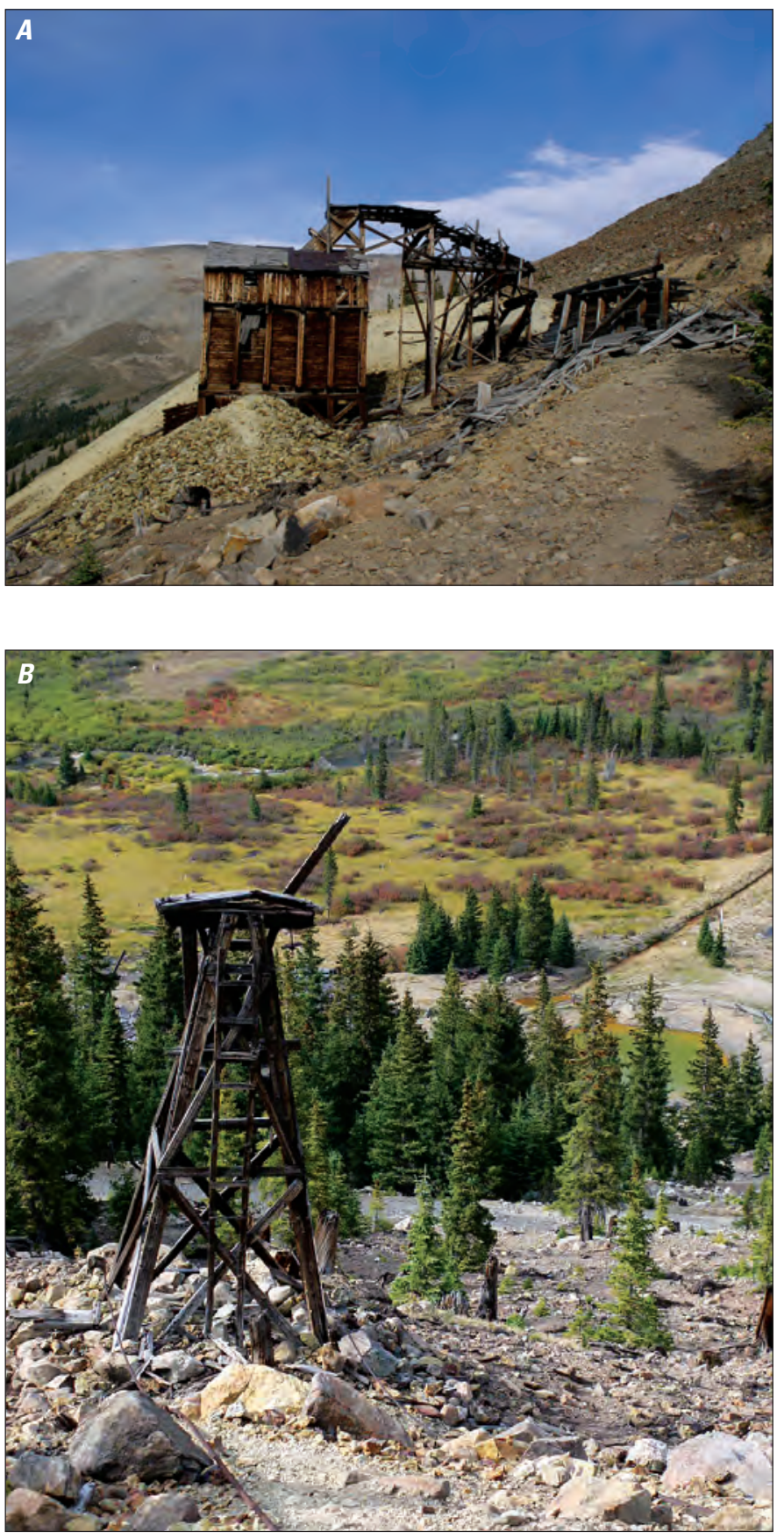

Figure 37. Two industrial landscapes in Colorado with historical value. $A$, Old mine in Peru Creek, east of Montezuma. $B$, Tram tower from mine in Peru Creek. Photographs by Anna Wilson. 


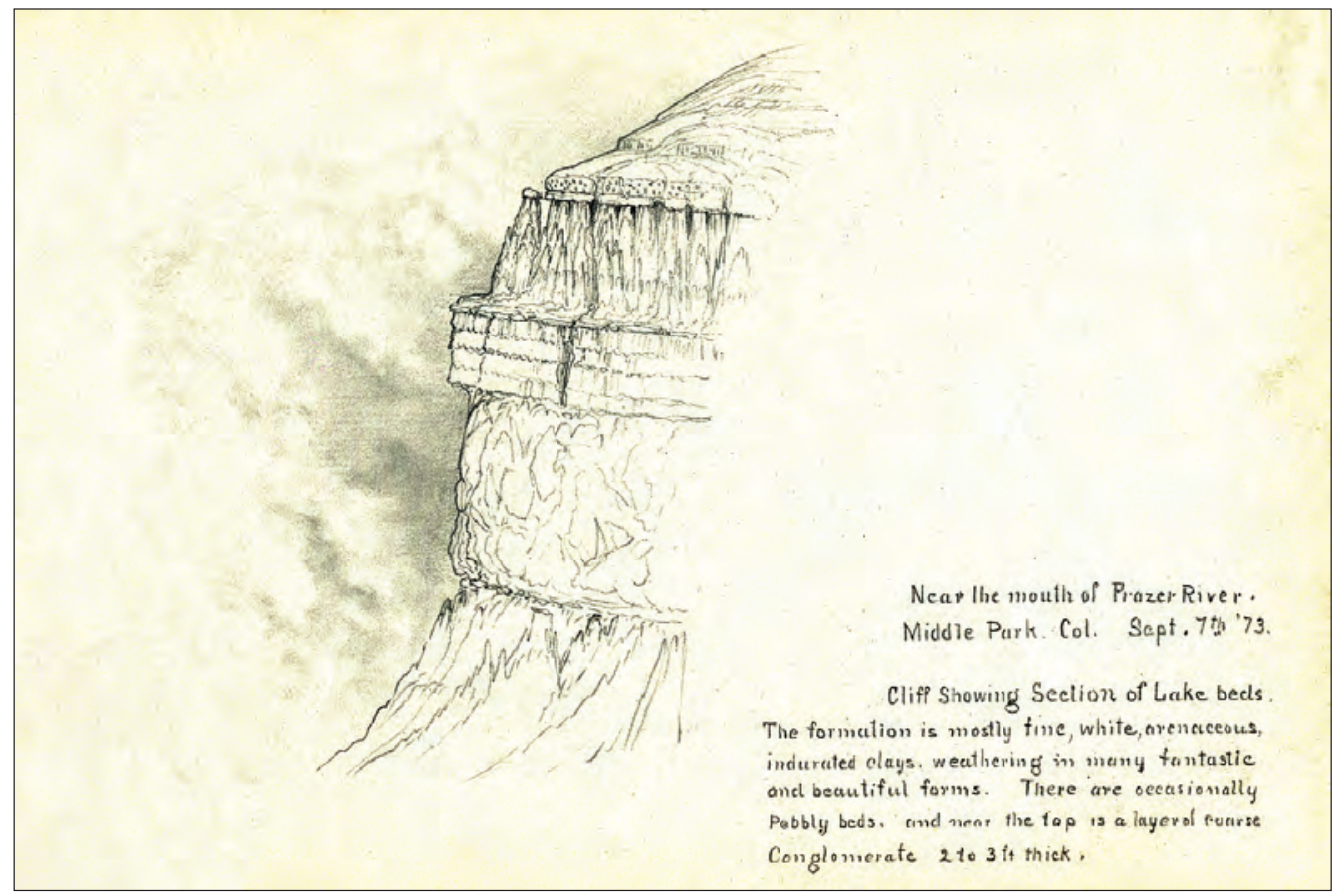

Figure 38. Sketch of clay cliff near mouth of Fraser River, Middle Park, Colo. Drawing by W.H. Holmes, 1873, U.S. Geological and Geographical Survey of the Territories (Hayden Survey) Sheet no. 39. Courtesy of USGS Photographic Library.

\section{Classification by Use}

Six groups of clay were recognized by the U.S. Bureau of Mines (U.S. Environmental Protection Agency, 1995c), and each has specific uses. The groups are ball clay, bentonite, fire clay, fuller's earth, kaolin, and common clay and shale. Materials commercially referred to as pottery clay (clay used for pottery and stoneware) are principally kaolin or ball clay; refractory clay (clay that has a high melting temperature) may be kaolinite, flint clay, plastic fire clay, or ball clay, or it may be various calcined materials (Arkansas Geological Survey, 2009).

\section{Ball Clay}

The name "ball clay" reflects the early English tradition of extracting clay in cubical blocks that became rounded during handling and storage. Ball clay is sedimentary in origin and usually contains kaolinite, mica, and quartz (Industrial Minerals Association North America, 2004). Its characteristic high plasticity, strength, and light or white color after firing make it an excellent clay to use for floor and wall tiles and sanitary ware such as sinks or toilets (Virta, 2004).

\section{Bentonite}

Bentonite is formed by the devitrification and chemical alteration of volcanic ash, tuff (that is, consolidated pyroclastic rock), or glass; other igneous rocks; or rocks of sedimentary origin. It consists predominantly of smectite, a group of clay minerals (also called montmorillonite group clay minerals) (Industrial Minerals Association North America, 2004). Two categories of bentonite, swelling and nonswelling, are recognized. Sodium bentonite, the swelling clay, can absorb water many times its original dry volume and possesses a high dry-bonding strength, whereas calcium bentonite, the "nonswelling" type, swells to a much lesser degree when wet and usually possesses greater adsorptive characteristics (Dumont, 2004). The largest swelling-bentonite deposits, which are in Wyoming, Montana, and South Dakota, are commonly called Western-type bentonite (Elzea and Murray, 1994).

Bentonite is used as pet waste absorbent in cat litter, as a binder in animal feed pellets, in drilling muds, iron ore pelletizing, sand molds for metal casting, wastewater purification, detergents, paper manufacture, and as a sealing material or liner for landfills.

\section{Fire Clay}

Fire clay is composed primarily of kaolinite with a high content of alumina and silica and few impurities that lower the fusion point of the clay. The clays are refractory (resistant to heat) and withstand temperatures of $1,500^{\circ} \mathrm{C}\left(2,700^{\circ} \mathrm{F}\right)$ before melting (U.S. Environmental Protection Agency, 1995c). For this reason, fire clays are used in heat-resistant products such as glass furnaces, foundries, kilns, and crucibles. 


\section{Fuller's Earth}

"Fuller's earth" traditionally was used by textile workers (fullers) for whitening, degreasing, or fulling (shrinking and thickening) wool by kneading it in a clay-water mixture (Bates and Jackson, 1987). It may also be called natural bleaching clay. The term is used for any fine-grained material with absorbent and bleaching properties (Elzea and Murray, 1994).

The clays in fuller's earth are similar to those in bentonite, but they are typically high in magnesia and able to adsorb impurities (U.S. Environmental Protection Agency, 1995c). Fuller's earth is formed by the alteration of volcanic ash or by direct chemical precipitation of the clay mineral montmorillonite in shallow marine basins (Dumont, 2004).

Applications include pharmaceuticals designed to absorb toxins, bacteria, and alkaloids and to treat dysentery; it is also used to remove contaminants from water and drycleaning fluids; in the manufacture of wallpaper; and as an extender or filler for plastic, paint, and putty (Dumont, 2004).

\section{Kaolin}

The word kaolin is derived from the Chinese kauling, meaning high ridge where clay deposits were worked thousands of years ago (WBB Minerals, 2005). Kaolin is a fine, usually white, china clay consisting of pure kaolinite, $(\mathrm{OH})_{8} \mathrm{Al}_{4} \mathrm{Si}_{4} \mathrm{O}_{10}$, or related clay minerals. Kaolin minerals are generally derived from the alteration or weathering of alkali feldspars and micas (Bates and Jackson, 1987). Kaolin is one of the purest clays and is used in porcelain, rubber tire manufacturing, inks, paints, plastics, and medicines, and as a main ingredient in glossy paper.

\section{Common Clay and Shale}

Common clay and shale are composed mainly of illite or chlorite, but they may also contain kaolin and montmorillonite. Common clay has a vitrification point below $1,100^{\circ} \mathrm{C}\left(2,000^{\circ} \mathrm{F}\right)$ (U.S. Environmental Protection Agency, 1995c). Shale is a fine-grained laminated sedimentary rock in which the original constituents were clay and silt-size particles. Shales composed predominantly of clay minerals easily split into thin flat plates or sheets (Arkansas Geological Survey, 2009). Shale that has hardened in response to heat and pressure is slate, a metamorphic rock used in building construction.

Some clays (and also shales, slates, and fine-grained mine wastes) will, when fired, expand ("bloat") into a frothy mass with closed cellular texture. Those materials are thus desirable for making lightweight aggregate (Arkansas Geological Survey, 2009). Shale and slate are also used in the manufacture of building materials such as paving bricks, tile, and Portland cement and as an impermeable liner in ponds or wastewater impoundments.

\section{Geology of Colorado Clay and Shale Deposits}

Clay generally forms in one of two ways: at the surface during the chemical weathering of aluminum-silicate minerals by carbonic acid or in the subsurface by the alteration activity of acidic hydrothermal fluids circulating through fault systems and porous rock. Clays may be found in soil horizons, continental and marine sediments, geothermal fields, volcanic deposits, and weathered rock formations (Foley, 1999). Clays generally swell when wet and shrink when dry. The physical properties that determine the commercial value of clays include firing temperature, percentage of shrinkage or swelling on firing, plasticity index, bloating characteristics, fired color, fired strength, and percentage of fines (slack) produced upon crushing (Arkansas Geological Survey, 2009).

Many times during the Cretaceous Period, 145-65 megaannum (Ma or millions of years ago), an inland sea advanced and retreated across central Colorado. Where advancing seas were deepest, marine shales were deposited; as the coastline moved back and forth across the region, sandstones were deposited near shore. Several central Colorado marine shales are clay rich and are suitable for brick, fire, or pottery clays (fig. 39). In eastern Colorado, Cretaceous shales of the Glencairn Shale Member of the Purgatoire Formation and the Dry Creek Member of the Dakota Sandstone form the largest economic clay deposits (Waage, 1953), although clay has also been mined from the Graneros, Niobrara, and Pierre shales and the Laramie Formation and Fox Hills Sandstone. In addition, shales contained in the Permian Lykins Formation, Jurassic Morrison Formation, and Tertiary Dawson Formations have been mined for their clays. Even Pleistocene loess was mined for manufacturing bricks (Patterson, 1964). In western Colorado, the major clay-producing units are the Mancos and Lewis shales, the Mesaverde Group, the Dakota Sandstone, and some Jurassic shales (Waage, 1953). Uplift and erosion has removed these units from much of the mountainous areas that underlie central Colorado's national forests, but where they have been preserved along mountain fronts clay resources may exist.

In addition to sedimentary processes, clays can also form when hydrothermal fluids (generated during the emplacement of felsic to intermediate volcanic magmas and shallow intrusive magmas) alter preexisting rocks. Rocks containing abundant feldspar minerals are particularly susceptible to hydrothermal alteration. Depending on the composition and acidity of the hydrothermal fluids, a smectite clay, such as montmorillonite, or kaolinite and halloysite may be formed (Hosterman and Orris, 1998a,b). Deposits of hydrothermally altered clays tend to be small, although a few attain economic volumes-such as those in porous volcanic tuffs at Westcliffe, Silver Cliff, and Creede, Colo. (Patterson, 1964).

\section{Mining and Production}

Most domestic clay and shale deposits are mined from open pits by heavy machinery such as draglines, power shovels, and bulldozers.

Ball clay is extracted from quarries and then blended with other raw clay to obtain specific characteristics. Processing includes shredding the clay into golf-ball-sized pieces, drying, and grinding (Industrial Minerals Association North America, 2004). 


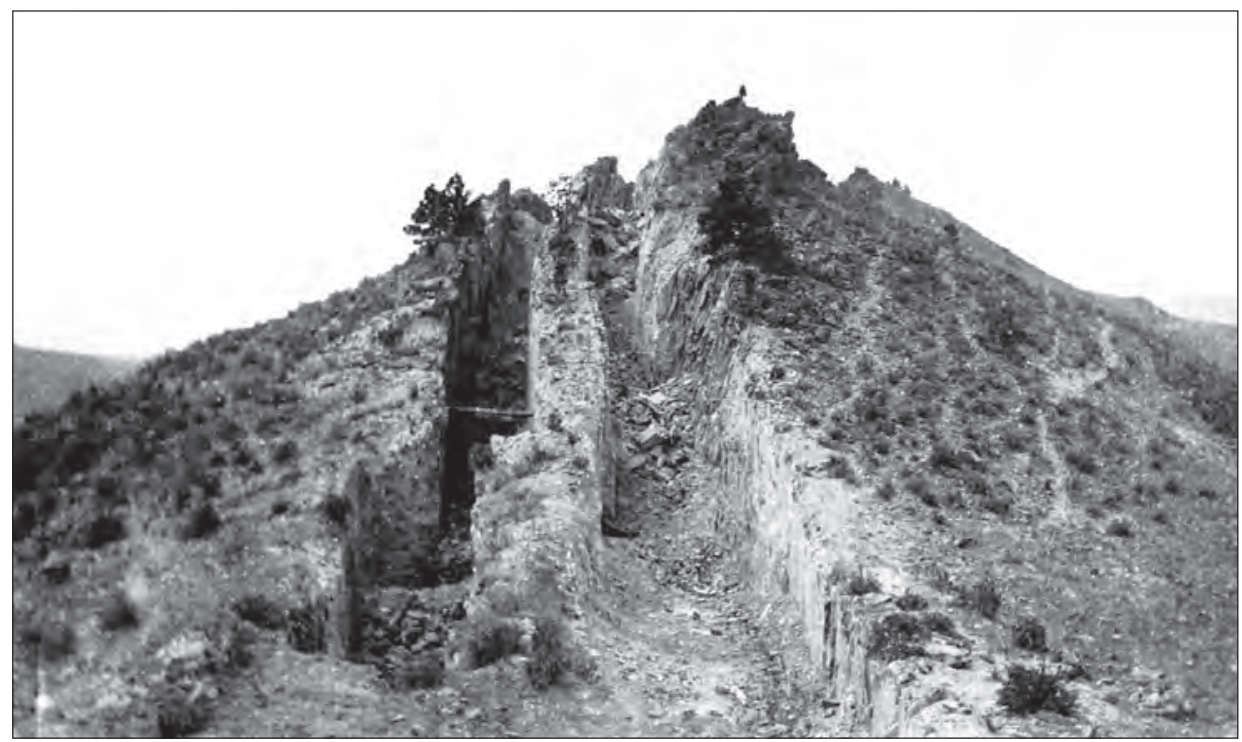

Figure 39. Fire clay, plant-bearing sandstone, and shale in Dakota Sandstone hogback, $3 \mathrm{mi}$ south of Golden, Jefferson County, Colo., 1922. Photograph by W.T. Lee. Courtesy of USGS Photographic Library.

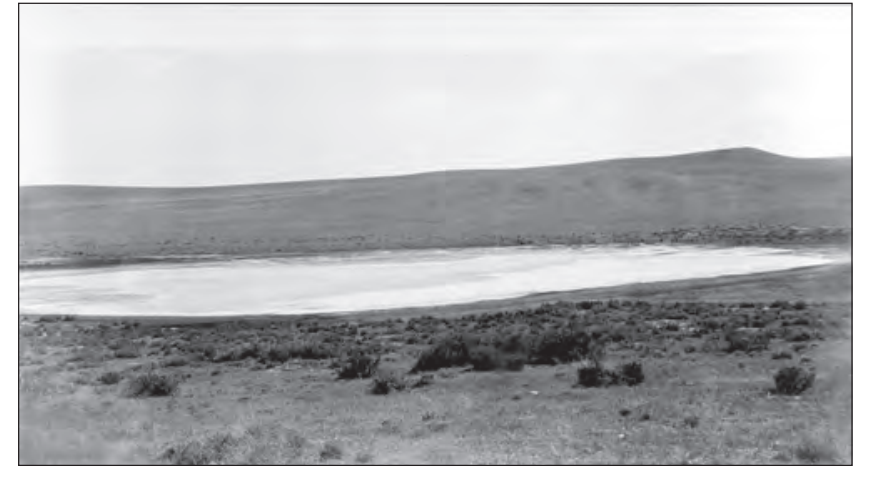

Figure 40. Alkali pond on Benton Shale, which drains poorly owing to a high bentonite content, 1 mi west of Howell, Albany County, Wyo., 1905. Photograph by N.H. Darton. Courtesy of USGS Photographic Library.

Because bentonite is so slippery, deposits generally can't be worked in wet weather; well-drained deposits are worked in dry, warm weather and poorly drained ones in dry cold weather (Dumont, 2004) (fig. 40). Most bentonite and some fuller's earth deposits are selectively mined (Dumont, 2004) to obtain a relatively high-grade product (at a somewhat higher cost). Various grades of clay are mined and stockpiled separately and then blended to obtain desired physical properties. If necessary, bentonite is activated with the addition of soda ash $\left(\mathrm{Na}_{2} \mathrm{CO}_{3}\right)$ (Industrial Minerals Association North America, 2004). Bentonite is then dried and either sieved (into a granular form), or milled (into powder) according to its end use.
Fire clay is more apt to be mined underground because higher quality fire clay is found at depth (Pickering and Murray, 1994; U.S. Environmental Protection Agency, 1995c). Fire clay is mined, transported to a processing plant, and stockpiled (sometimes for 6 to 12 months to produce smaller weathered particles and improve plasticity) (U.S. Environmental Protection Agency, 1995c). The clay is then crushed, ground, and dried.

Kaolin is washed by high-pressure water jets (hydraulic mining) from the surrounding rock into a clay suspension. Mechanical systems remove any unwanted quartz and mica before the suspension is pumped into large tanks where the clay settles. Excess water is drained and the slurry is pumped out to be filtered, dried, and blended.

Some materials-for example, kaolin-will receive further processing (table 8). Grit (mostly quartz and feldspar) may be removed from kaolin solely by dry mechanical processes ("dry processing," which yields a lower quality product) or by mechanical, electromagnetic, and chemical processes ("wet processing," which yields a purer product) (U.S. Environmental Protection Agency, 1995a,c; Christie and others, 2001b). Kaolin may also be processed into a slurry (by "blunging"); the slurry can then be transported by pipeline. This process lowers costs, allows better quality control, keeps heavy trucks off the roads, and can reuse old mine pits in the area to dispose of impurities (Pickering and Murray, 1994).

In 2003, Colorado produced an estimated 236,000 tons of common clays valued at $\$ 1.26$ million (Cappa and others, 2003); in 2004, it produced 289,000 tons valued at \$1.4 million (Cappa and others, 2004). 
Table 8. Clay processing operations by type of clay (modified from U.S. Environmental Protection Agency, 1995c).

[--, not applicable]

\begin{tabular}{|c|c|c|c|c|c|c|}
\hline Process & Ball clay & Bentonite & $\begin{array}{l}\text { Common clay } \\
\text { and shale }\end{array}$ & Fire clay & $\begin{array}{l}\text { Fuller's } \\
\text { earth }\end{array}$ & Kaolin \\
\hline Mining & $x$ & $x$ & $x$ & $x$ & $x$ & $x$ \\
\hline Stockpiling & $x$ & $x$ & $x$ & $x$ & $x$ & $x$ \\
\hline Crushing & $x$ & $x$ & $x$ & $x$ & $x$ & $x$ \\
\hline Grinding & $x$ & $x$ & $x$ & $x$ & $x$ & $x$ \\
\hline Screening & -- & -- & $x$ & $x$ & $x$ & $x$ \\
\hline Mixing & $x$ & -- & $x$ & -- & -- & $x$ \\
\hline Blunging1 & -- & -- & $x$ & -- & $x$ & $x$ \\
\hline Air flotation & $x$ & -- & -- & -- & -- & $x$ \\
\hline Slurrying & $x$ & -- & -- & -- & -- & $x$ \\
\hline Extruding & -- & -- & $x$ & -- & $x$ & -- \\
\hline Drying & -- & $x$ & $x$ & $x$ & $x$ & $x$ \\
\hline Calcining & -- & -- & -- & $x$ & -- & $x$ \\
\hline Packaging & $x$ & $x$ & -- & $x$ & $x$ & $x$ \\
\hline Other ${ }^{2}$ & $x$ & $x$ & -- & $x$ & $x$ & $x$ \\
\hline
\end{tabular}

${ }^{1}$ Blunging - Wet processing of kaolin which produces a slurry that can be piped to its destination.

${ }^{2}$ Other processes include water fractionation, magnetic separation, acid treatment, bleaching, shredding, pulverizing,weathering, blending, cation exchange, granulating, air classifying, and dispersing.

\section{Sand and Gravel (Construction)}

Sand and gravel have been used since ancient times for construction. The oldest paved road known was built more than 5,700 years ago to ease the transport of granite blocks to the pyramids in Egypt (Christie and others, 2001a).

"Sand and gravel is defined as continuously graded unconsolidated material (sediment) present on the Earth's surface as a result of the natural disintegration of rocks. *** It is composed predominantly of the mineral quartz, although gravel may also consist of various resistant rock types, such as novaculite, chert, and sandstone” (Arkansas Geological Survey, 2009). The manmade equivalent of sand and gravel is crushed stone, broken by mechanical means into smaller fragments.

The Wentworth scale (Wentworth, 1922) is the common scale used by geologists to describe the size of rock particles. Rounded rocks that are 0.08-2.5 inches (in.) (2-64 mm) in diameter are called pebbles; those that are 2.5-10 in. (64-250 mm) diameter are called cobbles, and those larger than 10 in. $(250 \mathrm{~mm})$ diameter are called boulders. Pebbles and cobbles are collectively known as gravel. Sand grains are those smaller than $2 \mathrm{~mm}$ (0.08 in.). Particles smaller than 1/16 mm are called silt and those smaller than 1/256 mm are called clay. "In the aggregate-producing industry, gravel consists predominantly of particles larger than $4.75 \mathrm{~mm}$ (retained on a U.S. Standard No. 4 sieve), whereas sand consists of particles predominantly between $4.75 \mathrm{~mm}$ and 75 [as in the original report; should be
0.075] $\mathrm{mm}$ (passes through a No. 4 sieve but is mostly retained on a No. 200 sieve" (Christie and others, 2001a, p. 6).

Fine aggregate (sand) and coarse aggregate (gravel and crushed stone) are used in the construction of nearly all buildings and public works projects and are the main filtering agent of water and sewage filtration systems. Nearly half of all construction sand and gravel produced each year is used in concrete aggregate and concrete products (such as block, bricks, and pipe). The remainder is used for asphalt, road-base material, railroad ballast, snow and ice control, and water filtration. The use of recycled aggregate, mostly from concrete surfaces, structures, and asphalt pavements, is increasing (Bolen, 2004a).

Worldwide, more sand and gravel is mined annually than any other industrial material; yet domestic shortages of construction sand and gravel are expected to increase in urban and industrialized areas (Bolen, 2004a). Few deposits meet the construction ideal of 60 percent gravel and 40 percent sandenough gravel for use as road base or bituminous aggregate and enough sand for use in concrete (Goldman, 1994). The construction of one mile of a typical four-lane interstate highway requires 85,000 tons of aggregate. Germany uses twice that amount of material in building one mile of its autobahn. Construction of an average six-room house in the United States requires 90 tons of aggregate, larger ones claim as much as 400 tons (Keller and Widmann, 2002), and an average-sized school or hospital requires about 15,000 tons (Langer and Glanzman, 1993). 


\section{Geology of Colorado Sand and Gravel Deposits}

Thick, extensive sand and gravel deposits in central Colorado occur in five basic Quaternary geologic settings: alluvial fans, high-elevation dissected terraces, intermediateelevation terraces, low-elevation terraces, and floodplains (Lindsey and others, 2005). They may also be found in older, partially cemented and hardened, conglomerates. High-energy streams carrying material eroded from the crystalline rocks of nearby mountains lose carrying capacity after the streams exit the mountains and the stream gradients decrease; the streams then deposite their sediment load.

Terraces and floodplains are found along major streams that drained the mountain uplifts during the Quaternary; the different elevations represent deposits of different ages. High terraces contain the oldest deposits and low terraces and floodplains the youngest. These deposits contain outwash transported during wetter periods of the Pleistocene. Some of the deposits are glacial outwash, but some deposits formed in drainage basins that were not glaciated.

The floodplains and low terraces are the principal source of high-quality sand and gravel in central Colorado. Older gravels of the intermediate and high terraces are not commonly used for high-specification aggregate because they contain boulders, cobbles, and pebbles that are soft and friable owing to weathering. Mountain-front alluvial fans are also avoided because the deposits are poorly sorted, and processing typically produces large amounts of fine waste products. In addition, older Pleistocene alluvial fans may be highly weathered (Lindsey and others, 2005). Nevertheless, as environmental concerns make it more difficult to mine gravels along major ephemeral streams, alluvial fans may provide an alternative source. Sand has been commercially exploited in the San Luis Valley and at Rocky Flats south of Boulder, Colo.

Another potential alternative source of sand and gravel is unconsolidated to partially consolidated Tertiary conglomerates, mainly of Miocene and Pliocene age, exposed in various portions of central Colorado. These rocks accumulated as alluvial fans along the borders of downfaulted blocks related to the Rio Grande rift zone and in the floodplains of major late Tertiary drainages (for example, Dry Union Formation in the upper Arkansas River Valley, north of Salida (Van Alstine, 1969).

\section{Mining and Production}

Many prime sand and gravel deposits are located in or adjacent to flowing streams and rivers (fig. 41A). If the water table is low or can be regulated, the deposits may be extracted from the ground by front-end loaders, power shovels, or draglines. Otherwise, the deposits are dredged. Dredges are mounted on boats or barges and remove sand and gravel by suction. Dredging also loosens fine sediment along with the sand and gravel, which increases the turbidity of water downstream. Sediments are collected and agitated with the aid of slurry pumps that dewater the load.
Once collected, the sand and gravel is passed across a series of screens and split into size increments ranging from dust to boulders (fig. 41B). Larger fragments may be used for erosion control, reclamation, and other uses, or they may be crushed (U.S. Environmental Protection Agency, 1995c). Sized material may be sold directly or may be blended with other size fractions to meet the aggregate specifications of a given customer. Specimens of chalcedony, agate, jasper, and petrified wood may be recovered from certain gravel and sand pits (Sinkankas, 1988).

In some cases, sand and gravel are washed to remove excess calcium carbonate, clay, organic impurities, or other surface coatings that may degrade the binding properties of the material.
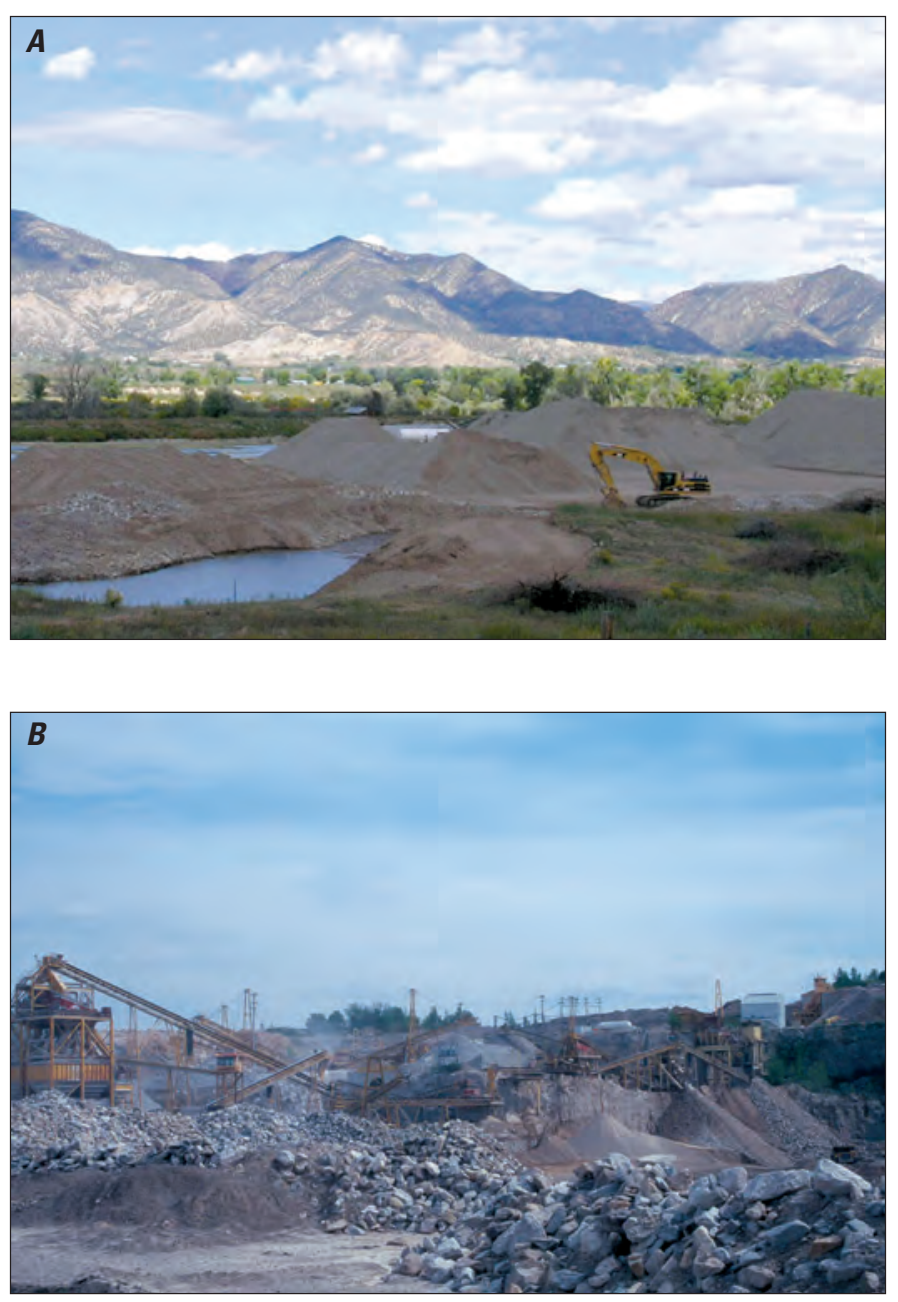

Figure 41. Stockpiles at sand and gravel mines. Large amounts of sand and gravel are extracted and processed in the United States. $A$, Sand and gravel mine along the Colorado River near Rifle, Colo. $B$, Sand and gravel are sorted using screens and belt conveyors. In 2005, this processing facility in Missouri produced more than 100 products from aggregate and rock. Photographs by B. Arbogast. 
In 2003, Colorado produced 41 million tons of sand and gravel valued at \$205 million (Cappa and others, 2003); in 2004, it produced about 45.5 million tons of sand and gravel valued at \$238 million (Cappa and others, 2004).

\section{Silica Sand (Industrial)}

The word silica is derived from the Latin silex, meaning flint or quartz (Merriam-Webster, 2009). Silica $\left(\mathrm{SiO}_{2}\right)$ is abundant in rocks, and the weathering of those rocks can free it. It also forms minerals (varieties of quartz) that contain only silicon, oxygen, and traces of other elements. Silica can be so fine grained that it is called cryptocrystalline or amorphous; examples are chert, chalcedony, or flint, and diatomite, which is biological in origin. Or, it may be crystalline, as in quartz.

Silica sand deposits, which are less common than construction sand and gravel deposits, meet stringent quality requirements (National Industrial Sand Association, 1997). Almost half of all silica sand produced in the United States today is used to manufacture glass (Zdunczyk and Linkous, 1994). Crystalline silica was used for glass manufacture more than 5,000 years ago in Egypt (U.S. Bureau of Mines Branch of Industrial Minerals, 1992). Silica sand is invaluable in the production of metal casting (foundry molds), metallurgy, chemical production, building products, paint, ceramics and refractories, water filtration, abrasive and grinding materials, oil and gas recovery (as hydraulic fracturing sand), and recreation (athletic fields and golf courses) (Zdunczyk and Linkous, 1994; Industrial Minerals Association North America, 2004).

\section{Geology of Colorado Silica Sand Deposits}

The durability of sand, a common product of the erosion of bedrock, causes large quantities to remain in stream channel, terrace, and alluvial fan deposits. Common sand deposits, however, contain many mineral impurities such as clay, feldspar, and iron oxides and typically are poorly sorted - that is, they contain a wide range of particle sizes. Treating this material to produce industrial-grade sand is costly; sand that has been naturally sorted and cleaned is much more economical. Extensive deposits of nearly pure quartz $\left(\mathrm{SiO}_{2}\right)$ sand formed near the shores of shallow seas during much of Phanerozoic time (Ketner, 1973). In Colorado these deposits are represented by numerous widespread sandstone units that accumulated where wave and current action thoroughly broke down softer minerals and washed their debris away, leaving a sand composed mostly of quartz. The Permian Lykins Formation and the Cretaceous Dakota Sandstone that crop out along the eastern flank of the Front Range and Wet Mountains have provided the majority of the industrial sand in Colorado. Other units that have been mined on a small scale for industrial sand include the Cambrian Sawatch Quartzite, the Ordovician Harding Sandstone, the Devonian Parting Quartzite member of the Chaffee Formation, the Pennsylvanian Fountain
Formation, the Permian Lyons Sandstone, the Jurassic Morrison Formation, the Cretaceous Lytle Sandstone Member of the Purgatoire Formation, Codell Sandstone Member of the Carlile Shale, Trinidad Sandstone, Fox Hills Sandstone, and Laramie Formation, and the Tertiary Dawson Formation (Carter, W.D., 1964).

\section{Mining and Production}

High quality industrial sand above the water table is mined from open pits; below the water table it is dredged. Shallow-water dredges may be hydraulic (fig. 42) or mechanical (such as draglines or clamshells). Some sands need only to be screened in order to meet a buyer's specifications, but others first undergo blasting and crushing. Beneficiating (for example, washing, screening, scrubbing, drying, and blending) of the ore may be necessary to increase the silica
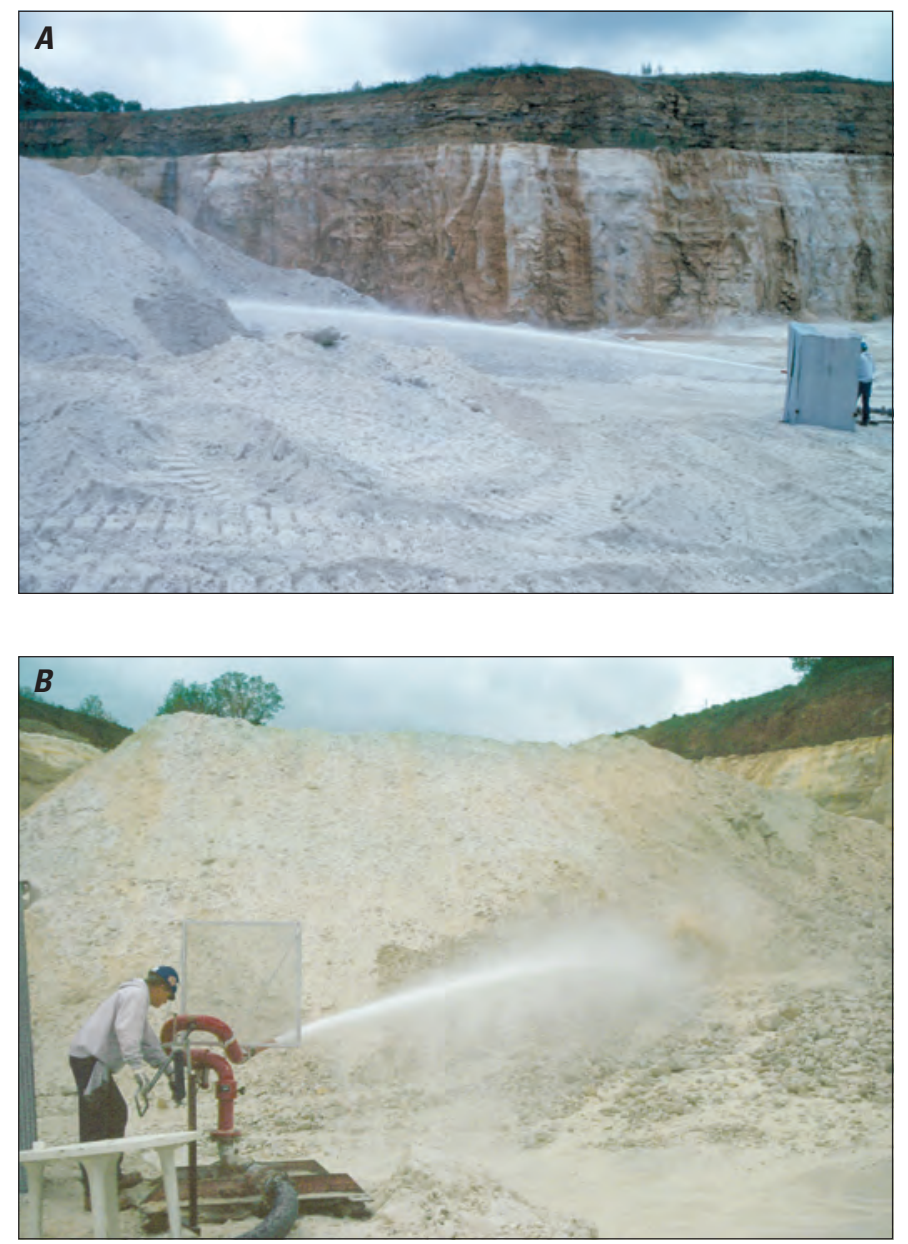

Figure 42. Extraction of industrial sand by hydraulic mining, which is limited to a depth of $60 \mathrm{~m}$ (about $200 \mathrm{ft}$ ). A, Sand is recovered by strong jets of water and transported underground to a beneficiation plant. $B$, Closeup of operation. Photographs by B. Arbogast. 
content and obtain the optimum size for a given purpose. Acid leaching may be required to produce high-purity industrial silica sand (Zdunczyk and Linkous, 1994). Froth flotation may be used to remove mica, feldspar, or iron-bearing minerals (U.S. Environmental Protection Agency, 1995c). Froth flotation uses chemical reagents, followed by agitation and aeration, to create a foam that takes advantage of differences in minerals' surface characteristics; some minerals are caught in the foam whereas others sink. The process is said to have been invented by a miner who watched the process happening while washing dirty work clothing in his home washing machine (Denver Mineral Engineers, Inc., 2005).

The industrial sand and gravel industry is concerned with safety and health regulations and environmental restrictions (Dolley, 2004). Prolonged and excessive exposure to crystalline silica (but not noncrystalline, or amorphous, silica) dust can cause silicosis, a noncancerous lung disease (U.S. Bureau of Mines Branch of Industrial Minerals, 1992). Studies in the 1980s suggested that crystalline silica was also a carcinogen. Businesses that use materials containing 0.1 percent or more crystalline silica are regulated under Federal guidelines concerning worker training and ensuring that workers understand on-the-job hazards (U.S. Bureau of Mines Branch of Industrial Minerals, 1992).

In 2003, Colorado produced about 69,000 tons of industrial sand and gravel; the dollar value is not public information (Cappa and others, 2003); in 2004, it produced just over 77,000 tons valued at \$3 million (Cappa and others, 2004).

\section{Crushed Stone}

Crushed stone is aggregate that is derived by crushing bedrock. Although the crushed stone used in concrete and asphalt must meet rigid specifications, many rock types are suitable for producing crushed stone. Crushed stone suitable for construction is resistant to abrasion and to disintegration from repeated freezing and thawing (soundness) and meets other standards governing permissible range of grain size (gradation), deleterious materials, color, fines, specific gravity, water absorption, particle shape, concrete strength, and skid resistance (Herrick, 1994).

Generally, any rock (igneous, metamorphic, or sedimentary) that is strong and resistant to rough handling, physically stable under wet and dry conditions, stable through freeze or thaw cycles, and not chemically reactive with cement can be used for crushed stone if a large enough volume of the rock is available (Knepper, 2002). In addition, a potential source of crushed stone must meet strength and durability specifications; contain a volume that will allow at least 10 year and preferably 20 or more years of production; have an adequate market, a competitive transportation cost, and an acceptable environmental effect; and be acceptable to agencies that grant needed permits (Herrick, 1994; Arkansas Geological Survey, 2009).
Limestone and dolomite account for 71 percent of all crushed stone produced in the United States (Tepordei, 1999). The majority of crushed stone, 84 percent, is used for highway construction and maintenance projects (Tepordei, 2004). The use of crushed stone as an alternative to sand and gravel is increasing across the United States because stone quarries typically operate within a smaller area and can be located farther from urban areas and visually sensitive river valleys (Cappa and others, 2004).

\section{Geology of Colorado Crushed Stone Deposits}

A variety of igneous, metamorphic, and sedimentary rocks in Colorado have been used to produce crushed stone, including granite, gneiss, sandstone, limestone, and volcanic rock (Langer and Glanzman, 1993). Most granite that is not deeply weathered, hydrothermally altered, or strongly foliated makes good crushed stone regardless of its age. Precambrian granites, such as the Pikes Peak Granite and the Silver Plume Granite, are exposed over large areas of central Colorado and may be excellent sources of crushed stone. Some Precambrian metamorphic rocks have also been used for crushed stone. Metamorphic gneiss is the primary source rock for the quarries providing crushed stone to the metropolitan Denver area (Knepper, 2002). Metamorphic Precambrian quartzites, such as those exposed in Coal Creek Canyon on the east flank of the Front Range and in Phantom Canyon and Wilson Park near Cañon City, make excellent crushed stone because of their chemical stability and hardness, but they have not been widely used because their limited occurrences are not in convenient locations and because they cause excessive wear and tear on mechanical crushers. Marble, a metamorphosed limestone or dolomite rock, has the physical and chemical properties to make good crushed stone, but it is usually more valuable as dimension stone.

Volcanic rocks, especially darker varieties such as basalt, make good sources of crushed stone. For example, the basaltic flow rock that caps North Table Mountain and South Table Mountain east of Golden produces high-quality crushed stone. The feeder vent (dike) that fed volcanic flows to the surface is exposed at Ralston Butte to the north, and similar rock in the Valmont dike near Boulder are good examples of volcanic rock used to produce high quality crushed stone in Colorado (Colton and Fitch, 1974; Knepper, 2002). Lighter colored (felsic) volcanic rocks that do not contain critical amounts of microcrystalline quartz - which reacts with cement to weaken concrete-can also make excellent crushed stone aggregate if the deposit is large enough. Abundant felsic volcanic rocks in central and southwestern Colorado that formed from superheated ash and lava (welded tuffs and ash flow tuffs; see Dimension Stone) commonly contain too much microcrystalline quartz to be used for concrete aggregate, but they do make good road base.

Although most sandstones, siltstones, and shales in the study area are too soft to make good crushed stone for concrete aggregate, some can be used for fill and road base. The 
most common source of crushed stone nationally is limestone or dolomite (Tepordei, 2004). Many carbonate units in Colorado could provide crushed stone for concrete aggregate, such as the Ordovician Manitou Dolomite and Fremont Limestone, the Mississippian Leadville Limestone, many limestones in the thick Pennsylvanian and Permian sedimentary section, and several Cretaceous limestones. Many of these units briefly provided crushed stone from small quarries (Lindvall, 1964). Longer term crushed-stone operations worked Ordovician carbonate units in the Cañon City, Colorado Springs, and Fort Collins areas. Well-indurated, silica-cemented sandstone, such as the Ordovician Harding Sandstone in some areas of Colorado, can also make good crushed stone.

\section{Mining and Production}

Drill holes are meticulously laid out on mine benches and are filled with explosive charges. Detonation of the charges fractures the rock and creates a loose rubble. Diesel-powered hydraulic shovels load haul trucks that then carry the rubble to a primary crusher. Conveyor belts transport the crushed stone for screening and secondary or tertiary crushers where it is broken down further to meet customer specifications.

Depending upon the type of stone, types of contaminants in the stone, and availability of pond space and water (Herrick, 1994), crushed stone may be processed by wet or dry methods. It may be washed to remove unwanted material and the waste water is then sent to settling ponds. Wet plants do not have the dust problems that may be associated with dry processing, but other methods may be used to suppress dust.

In 2004, about 10.4 million tons of crushed stone (valued at \$59.5 million) was produced in Colorado, an increase of 1 percent as compared with 2003 (Cappa and others, 2004).

\section{Limestone}

Limestone is a sedimentary rock that can originate in two ways: biologically, as shells and skeletons of marine organisms that accumulate in sediment (for example, chalk) and chemically, as $\mathrm{CaCO}_{3}$ (calcium carbonate or calcite) that precipitates from water and accumulates as limestone or travertine. The word calcium is derived from the Latin calx, meaning lime (Merriam-Webster, 2009). Limestone can also be physically altered by metamorphism to marble. The rock must contain at least 50 percent calcite $\left(\mathrm{CaCO}_{3}\right)$ to be classified as limestone (U.S. Environmental Protection Agency, 1995c). When the rock is a mixture of calcite and the mineral dolomite, $\mathrm{CaMg}\left(\mathrm{CO}_{3}\right)_{2}$, and dolomite makes up at least half of the rock, then the entire rock is referred to as dolomite (Bates, 1969; Eckel, 1997). Although the terms limestone and dolomite are often used interchangeably, limestone is not a suitable replacement for dolomite in its most important usethe manufacture of refractory dolomite and the preparation of heat-insulating materials (Arkansas Geological Survey, 2009).

Although limestone (including marble) can be used as a dimension stone and for rock fill and riprap, the bulk of crushed limestone is used as road base, concrete aggregate, and agricultural limestone. Limestone is also used in steel making, to treat water and sewage, and to neutralize acid waste.

Quicklime (CaO, calcium oxide) is another important product manufactured from crushed limestone. Archeological discoveries in Turkey indicate that quicklime was used as a mortar as early as 7,000 years ago (Mineral Information Institute, 2004). Quicklime is used in metallurgy, paper manufacture, water and sewage treatment, building materials, and ceramic products. Although limestone can substitute for lime in many applications, such as agriculture, fluxing, and sulfur removal, limestone is slower to react than quicklime and may have other disadvantages depending on the application (Miller, 2004a).

Reacting lime (calcium) with water forms hydrated or slaked lime, also known as calcium hydroxide or $\mathrm{Ca}(\mathrm{OH})_{2}$. Slaked lime is used to neutralize acid and to precipitate certain soluble or gaseous impurities such as acids and heavy metals.

\section{Geology of Colorado Limestone Deposits}

Most carbonate rocks in central colorado are sedimentary marine limestones formed primarily from the calcite shells and skeletons of marine organisms. Because magnesium can be added while sediment is converted to rock (diagenesis), the dominant mineral may change from calcite to dolomite. Thus, a single mapped formation may be a limestone in one geographic area and a dolomite in another.

In central Colorado, the thickest and most widespread carbonate units were deposited in a shallow sea during the Ordovician (Manitou Dolomite and Fremont Limestone) and the Mississippian (Leadville Limestone). The Leadville Limestone was quarried for decades at Monarch Pass and elsewhere by the Colorado Fuel and Iron Corporation for use as flux in making steel in Pueblo (Carter, D.A., 1964). Abundant thinner limestone beds have been mapped in the marine Pennsylvanian and Permian formations west of the Front Range (Minturn and Maroon Formations) and are a potential resource. One of these units, the Permian Ingleside Formation, was quarried in Larimer County to provide limestone for refining sugar by the Great Western and Holly Sugar factories; Leadville Limestone was also quarried near Glenwood Springs and Salida for use in sugar refining (Berlin, 1964). Relatively pure limestones and dolomites suitable for producing reagents (metallurgical limestone) occur in the Cretaceous Fort Hays Member of the Niobrara Formation, the Ordovician Fremont Limestone, and the Mississippian Leadville Limestone (Carter, D.A., 1964). Limestone for making cement is found in the Cretaceous Niobrara Formation, especially the Fort Hays Limestone Member, where it is exposed along the eastern flank of the Front Range and the Wet Mountains. Although the Leadville Limestone usually contains some dolomite, the formation is locally pure enough to be used to produce cement in the western part of the State (Wolfe, 1964). 


\section{Mining and Production}

Limestone is quarried from open pits and underground mines (fig. 43). Limestone that is to be used for ornamental purposes is extracted from the bedrock by saws and wedges. The rock is then either cut or carved to its final shape and polished. To obtain crushed limestone, the rock face is drilled and blasted; the stone is then crushed, dried if necessary, screened into various sizes, and washed to remove fines. Certain industrial and agricultural applications may call for further air classification (winnowing or air tabling) and milling followed by storage in enclosed silos and bins (Carr and others, 1994). To manufacture quicklime, crushed ore is heated at high temperature to drive off carbon dioxide and form calcium hydroxide
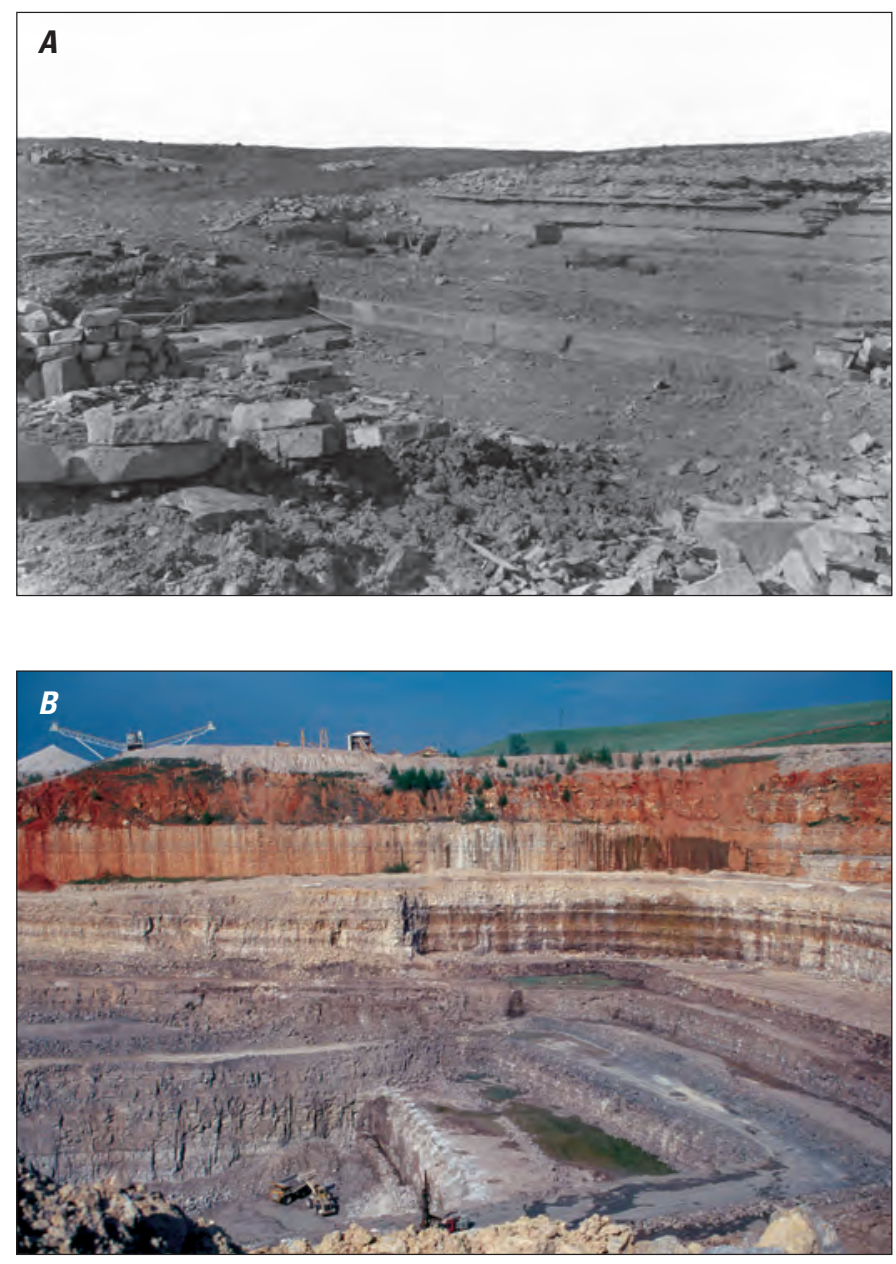

Figure 43. Two limestone quarries. $A$, Walls in Fort Hays (formerly Timpas) Limestone quarry show thickness of beds and interbedded layers of shale, southeast of La Junta, Otero County, Colo., 1904. Photograph by N.H. Darton. Courtesy of USGS Photographic Library. B, Tower Rock stone quarry near Saint Genevieve, Mo., a large limestone open pit, 2002. Photograph by B. Arbogast. (the ore is "calcined"). The U.S. Environmental Protection Agency has set limits that reduce toxic air pollutants from lime plants (Miller, 2004a).

In 2002, Colorado produced an estimated 4.6 million tons of crushed limestone valued at $\$ 30.9$ million (U.S. Geological Survey, 2003a), most of which went into cement. In 2004, Colorado produced about 2.6 million tons of cement, an increase of more than 50 percent as compared with the 1.7 million tons produced in 2003 (Cappa and others, 2004).

\section{Gypsum}

The word gypsum is derived from the Greek gypsos, meaning plaster (Merriam-Webster, 2009) or chalk. Gypsum $\left(\mathrm{CaSO}_{4} \cdot 2 \mathrm{H}_{2} \mathrm{O}\right.$, calcium sulfate dihydrate) occurs principally as selenite crystals, massive alabaster, and fibrous satin spar, all of which are soft enough to be scratched by a fingernail. Gypsum ore was first mined in North America, in Nova Scotia, in 1770; it was shipped to the eastern seaboard of the United States for use as fertilizer (Adams, 1993).

Almost 90 percent of gypsum is manufactured into wallboard (gypsum sandwiched between two layers of heavy paper) and plaster products (Olson, 2004a) (fig. 44). Gypsum is used for molds such as those that form dental prostheses, plate glass, and car parts; in plaster of Paris, match heads, soil conditioners, and fertilizer; and as a retarder (a component that slows down reactions) in Portland cement.

About a quarter of the total domestic supply comes from synthetic gypsum - gypsum that has been recovered from coal-fired generating stations by desulphurization of flue gas (Olson, 2004a). Near Florence, Fremont County, Colo., synthetic gypsum is produced from flue gas at a Holcim cement plant. This gypsum is then added to the cement later in the manufacturing process.

\section{Geology of Colorado Gypsum Deposits}

As sulfur-bearing rocks weather at the Earth's surface, gypsum is commonly produced; it is especially abundant around exposed sulfide mineral veins and mine dumps in central Colorado. However, economically extractable amounts of gypsum are found only in thick sedimentary rock units formed by the evaporation of shallow marine brines (fig. 45). This type of gypsum belongs to a family of rocks called evaporites, which also includes anhydrite, salt, dolomite, and salts of potassium and magnesium. A single evaporite stratigraphic sequence may contain each of these rock types, reflecting the changing composition of the brine with time.

The primary source of commercial gypsum in central Colorado is the Eagle Valley Evaporite. In Pennsylvanian time, a shallow sea occupied a narrow northwest-trending basin (the Central Colorado trough) between the Ancestral Front Range and Uncompahgre uplifts. Along the edge of the trough adjacent to the uplifts, a thick sequence of coarse clastic sediments accumulated (now the Maroon and Minturn Formations), whereas evaporation of the shallow sea toward 

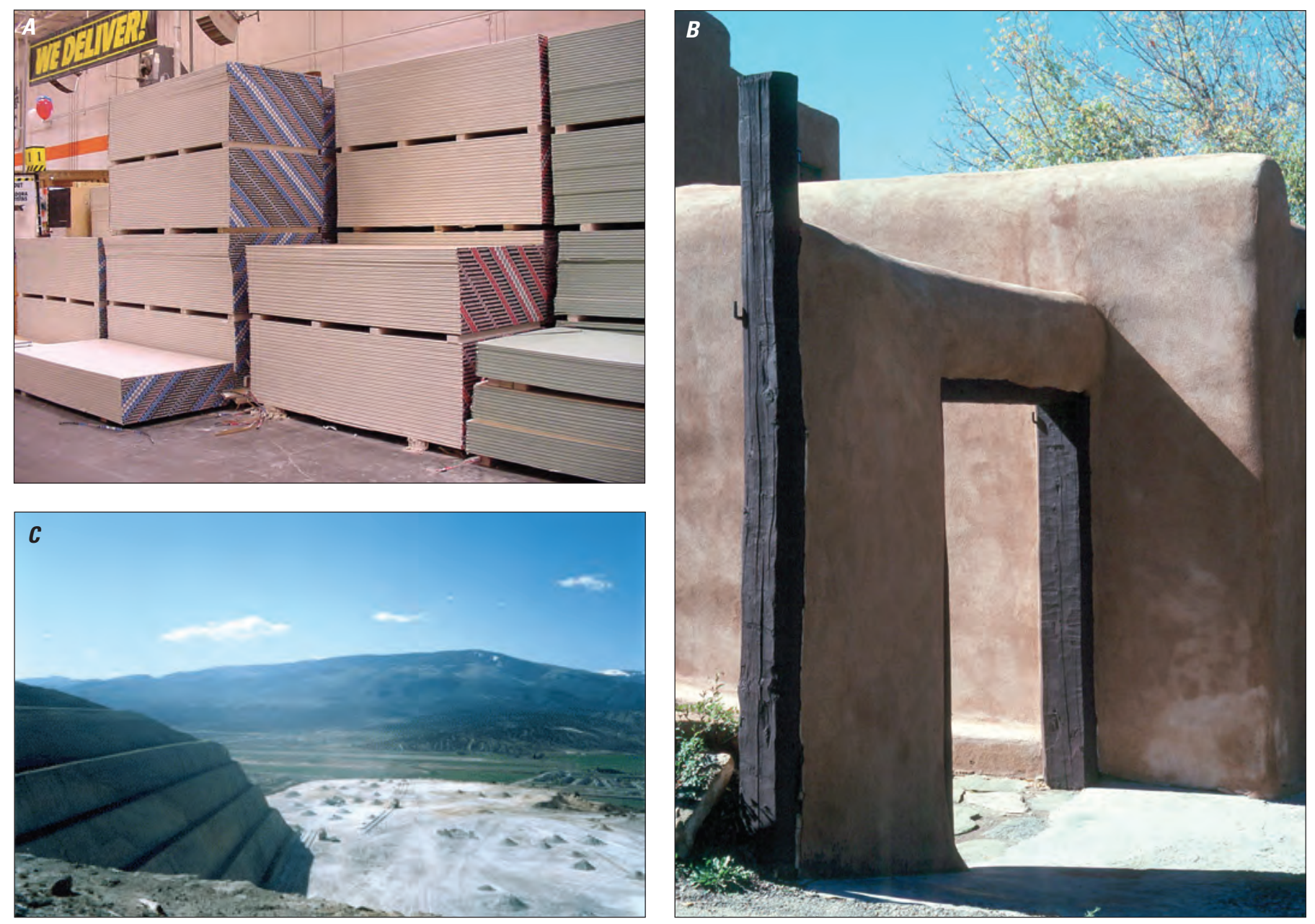

Figure 44. Two types of gypsum-containing construction materials used by the construction industry. $A$, Wallboard, which is made from gypsum, stacked at a home-improvement warehouse store. $B$, Building with stucco exterior. Stucco is a traditional building material in New Mexico. It was historically made from hydrated or slaked lime, water, and sand, to which straw or animal hair was added. Gypsum has largely replaced lime in contemporary stucco work. $C$, Gypsum mine in Eagle County, Colo. (Centex Construction Products, Inc.). The Eagle Valley Evaporite formation of Pennsylvanian age contains thick beds of gypsum. Photographs $A$ and $C$ by John Keller, Colorado Geological Survey. Photograph $B$ by B. Arbogast.

the center of the trough (Eagle Valley Basin) formed the deposits of bedded gypsum, anhydrite, halite (salt), and traces of potash salts of the Eagle Valley Evaporite sequence (Lovering and Mallory, 1962; Mallory, 1971). The transition between the clastic and evaporite sediments was uneven, such that gypsum locally occurs in the Minturn Formation and was mined along the Arkansas River southeast of Salida (Withington, 1964). Elsewhere in central Colorado, conditions were locally favorable for the formation of bedded gypsum during the Permian (Lykins Formation) and the Jurassic (Morrison and Ralston Creek Formations) (Vanderwilt, 1947; Withington, 1964). These deposits are relatively small and have been of only minor economic importance.

\section{Mining and Production}

In Colorado, gypsum is mined in open pits by large mobile grinders (mechanical rotomills) similar to the ones used to grind and recycle asphalt during highway repaving. Explosives are used on occasion to break apart more competent layers within the deposit. The ground gypsum is transported by front-end loader to a plant where it is further crushed and graded to specification. In a separate process, gypsum is ground up, boiled, and dehydrated (calcined), becoming the fine powder known as plaster of Paris or stucco.

In 2003, Colorado produced about 590,000 tons of gypsum (Cappa and others, 2003); in 2004 production increased to 645,000 tons (Cappa and others, 2004). 


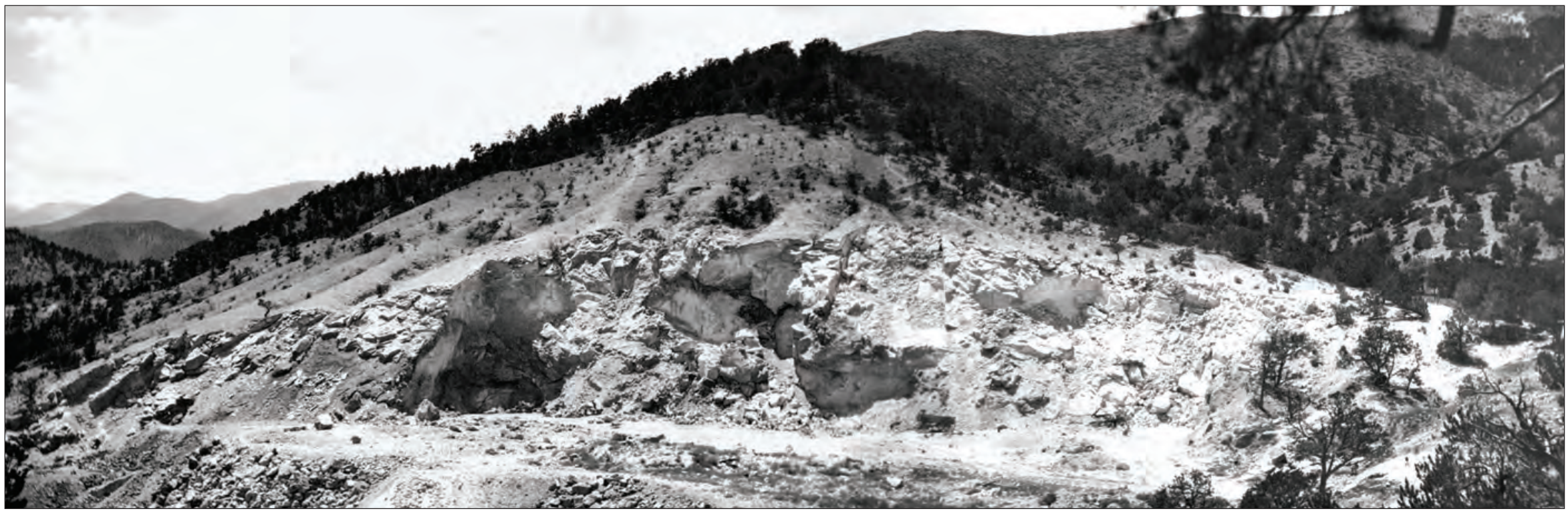

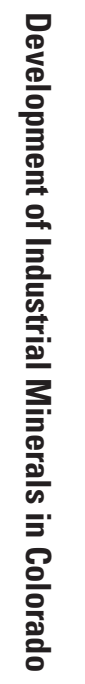

Figure 45. Panoramic photograph of a gypsum quarry, Colorado Portland Cement Company, Coaldale, Fremont County, Colo., undated. Photograph by E.F. Burchard. Courtesy of USGS Photographic Library. 


\section{Lightweight Aggregates-Pumice, Scoria, Perlite, and Vermiculite}

Lightweight aggregates have properties similar to those of natural aggregate, but they are less dense and therefore have lighter unit weights - for example, pumice, volcanic cinders, expanded shale, or expanded perlite and vermiculite. The use of lightweight aggregates speeds handling and can save money by replacing structural steel in foundations (Bates, 1969). In some applications, strength is greater than it would have been if heavier rock aggregate had been used (Arkansas Geological Survey, 2009). Lightweight aggregates are also used for hydroponics, soil conditioners, insulation, and filler.

\section{Classification of Lightweight Aggregates}

The lightweight aggregates are categorized as follows (U.S. Environmental Protection Agency, 1995b, p. 1) :

1. Natural lightweight aggregate materials-Prepared by crushing and sizing rock materials such as pumice and volcanic cinders

2. Manufactured structural lightweight aggregates—Prepared by heating certain types of shale, clay, or slate so the material expands into a porous product

3. Manufactured "ultralightweight" aggregates used for insulation-Prepared by heating ground vermiculite, perlite, and diatomite to extremely high temperatures

4. Byproduct lightweight aggregates-Prepared by crushing and sizing foamed and granulated slag, cinders, and coke breeze (fine-grained coke generated during iron and steel production).

In Colorado, pumice, scoria, perlite, and vermiculite deposits are of interest as sources of lightweight aggregate.

\section{Pumice}

The word pumice is from the Latin pumex, meaning foam (Merriam-Webster, 2009). All types of volcanic magma (basalt, andesite, dacite, and rhyolite) will form pumice (U.S. Geological Survey, 2000). Pumice appears frothy and full of bubbles owing to the escape of volcanic gases as the volcanic material solidified; it can be light enough to float on water. It is inert and does not react with components of concrete or steel. Pumicite, or volcanic ash, is finer grained than pumice; grains are generally less than 2 or $3 \mathrm{~mm}$ (0.08 in.) diameter (Bates, 1969).

Pumice is considered by some to be an environmentally benign product because no harmful production processes are involved and the waste matter generally is recovered. The overburden, reject ore, and mineral fines produced during mining and processing of pumice are used to reclaim the minedout areas (Bolen, 2004b).

In commerce and for practical uses, a distinction is made between pumice blocks and pumice powder (Stellman, 1998).
Seventy-five percent of pumice and pumicite is used to make lightweight construction materials such as concrete block and concrete; the remainder is used in abrasive cleaners, soaps, polishes, potting soil, and solutions used to wash new blue jeans before sale (U.S. Geological Survey, 2003a; Mineral Information Institute, 2004).

\section{Scoria}

The word scoria is from the Greek scoria, meaning excrement (Merriam-Webster, 2009). Scoria, or volcanic cinder, is similar to pumice. It is usually heavier, darker, and more crystalline than pumice (Bates and Jackson, 1987), and it is also less porous. Scoria is used in road base owing to its hardness and porosity, in cinder blocks and gas barbeque grills, and as the common landscaping material called lava rock.

\section{Perlite}

The word perlite is from the French perle, meaning pearl (Merriam-Webster, 2009). Perlite is a silica-rich volcanic glass that contains trapped water, which when heated escapes and expands the mineral 4 to 20 times its original volume (U.S. Environmental Protection Agency, 1995c). Perlite continues to be used as a substitute for vermiculite despite concerns about trace amounts of crystalline quartz (Breese and Barker, 1994; Hindman, 1994). Perlite is used as a lightweight aggregate in concrete and plaster and in potting soil, acoustical tiles, and thermal insulating materials.

\section{Vermiculite}

The term vermiculite comes from the Latin word vermiculus, meaning little worm (Merriam-Webster, 2009). It alludes to a worm-like (or accordion-like) shape produced by heating, which expands the material 6 to as much as 30 times its original thickness (fig. 46). In exfoliated form, vermiculite has the low density and biological inertness of expanded perlite (Hindman, 1994). These characteristics make it useful in absorbents and textured paints; in lightweight insulating fireproofing, concrete, and masonry fill; in horticulture as a growth medium, for bioremediation, and in animal feed.

Vermiculite has one drawback: it commonly contains other minerals, one of which may be asbestos. Asbestos is a very minor contaminant, and only a few ore deposits are known to contain more than trace amounts of asbestos minerals. However, exposure to airborne asbestos particles is linked with respiratory ailments and with cancer (U.S. Environmental Protection Agency, 2010).

\section{Geology of Colorado Lightweight Aggregate Deposits}

Both scoria and pumice are pyroclastic volcanic rocks composed largely of volcanic glass explosively erupted from gas-charged viscous silicic volcanoes (Vanderwilt, 1947; Bates, 1969). Frothy lava at or near the surface is explosively erupted into the air, rapidly cooled to volcanic glass, carried 


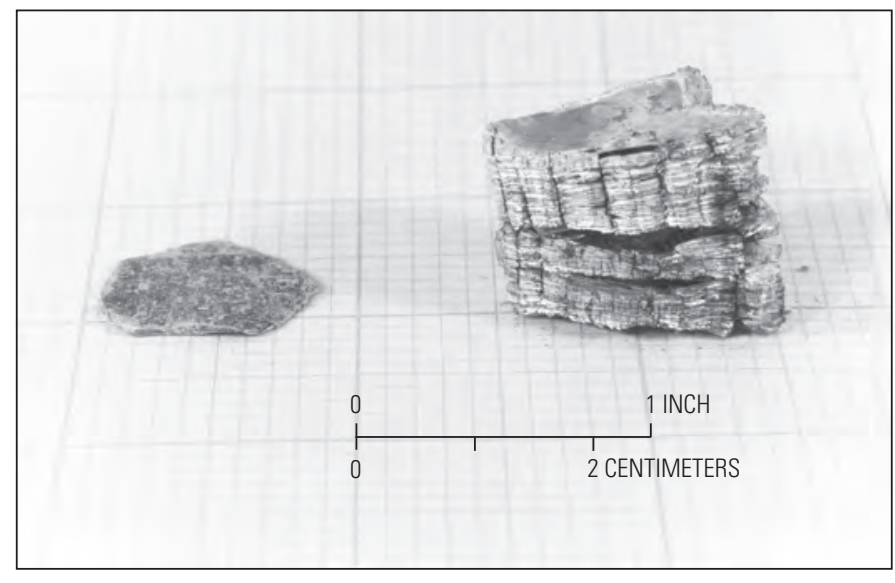

Figure 46. Raw vermiculite (left) and heat-expanded vermiculite (right). Vermiculite heated to $800-1,100^{\circ} \mathrm{C}$ expands because water contained in its crystal structure converts to steam that pushes crystal layers apart. Photograph from Van Gosen and others (2002, p. 5).

downwind, and deposited on land or in lakes forming deposits of tuff. During this process, particles are sorted by size as a function of distance from the vent, fine particles traveling farther. If sufficient heat is maintained, the glass fragments can be totally or partially welded together forming a light, porous rock. Otherwise, the particles are unconsolidated or are indurated only by secondary cement at a later time. Since the volcanic glass begins to devitrify to quartz and clay minerals relatively quickly, pumice is most common in deposits of Quaternary and Tertiary age. The scoriaceous cinder deposits of Gobbler Cone (Pliocene) and Dotsero and Willow Peak volcanoes (Holocene) in Eagle and Garfield Counties, Colo., are examples of sources suitable for lightweight aggregate (Streufert and others, 1997).

Perlite is also a silicic volcanic rock composed of glass. Originally it was thought that perlite was a primary volcanic rock formed by the rapid chilling of lava erupting onto the Earth's surface. Lack of a pumice outer shell and a crystalline core in perlite deposits suggested that the perlite may have been intruded at shallow depths that provided sufficient pressure to prevent the formation of pumice. More recently, it has been proposed that perlite is not a primary rock type but is formed by hydration of obsidian or rhyolite (Bates, 1969).

Vermiculite forms from the weathering of micas, chiefly biotite and phlogopite, by contact with surface water or groundwater in the zone of groundwater circulation (Bush, 1976; Van Gosen and others, 2002). Commercial quantities of vermiculite typically are produced where mica crystals are abundant and fairly large. Commercial vermiculite deposits form in a range of igneous and metamorphic rocks. In central Colorado, vermiculite is associated with Proterozoic gneisses, granodiorite, and granite; Cambrian diabase and alkalic plutonic rocks; and Tertiary volcanic rocks (Van Gosen and Bush, 2001). However, safe development proceeds cautiously because a preliminary reconnaissance study by the U.S. Geological Survey found amphibole asbestos minerals in at least two Colorado vermiculite districts (Van Gosen and others, 2002).

\section{Mining and Production}

Pumice, scoria, perlite, and vermiculite are usually mined by simple open pit methods such as bulldozers and front-end loaders but may be mined with traditional drilling and blasting methods. Crushing and screening to specification follows. Beneficiation generally does not alter the nature of the mineral itself other than by reducing or enlarging particle size. Wastes produced during beneficiation typically are merely unneeded sizes, such as clays (U.S. Environmental Protection Agency, 1995b).

Perlite or vermiculite may be selectively mined in deposits of variable quality (Breese and Barker, 1994; Hindman, 1994). Vermiculite may be processed by dry or wet methods. Dry beneficiation includes drying, dust collection, screening, and air classification (by winnowing or air tabling); wet beneficiation includes froth flotation, heavy media separation, and dewatering (Hindman, 1994). Expansion of perlite and vermiculite ore by high heat, a process called exfoliation, follows at processing plants commonly located away from the mines and close to consumers owing to the higher shipping costs of expanded ore (Breese and Barker, 1994; Hindman, 1994). Dust and sludge are among the mineral processing wastes generated; kiln drying and sifting produce the largest amounts of dust requiring control (Stellman, 1998). According to the U.S. Environmental Protection Agency (1995b), in 1995 all facilities used dry dust collection systems.

Pumice, perlite, and vermiculite are not presently mined in Colorado (John Keller, Colorado Geological Survey, oral commun., 2006). Volcanic cinder or scoria is currently mined in Colorado but the mining companies have withheld production information to avoid disclosing proprietary data (U.S. Geological Survey, 2003a; John Keller, Colorado Geological Survey, oral commun., 2006).

\section{Dimension Stone}

Dimension stone is indurated bedrock that is shaped into useful sizes for construction purposes such as tiles, paving stones, countertops, and walls. Any type of bedrock that is hard and durable and that can be cut or broken into useful forms can be used as dimension stone. The stone's ability to be polished and its color, grain texture, durability, and strength are important. The dimension stone industry classifies dimension stone as granite, marble, sandstone, or slate. Decorative or ornamental stone is more broadly defined by geologists as any stone used primarily for its color, texture, and general appearance rather than for its strength or durability (Barker and Austin, 1994). Crushed stone and rounded cobbles can also be considered decorative stone. 
A finished piece of building stone is an expensive product owing to labor costs (fig. 47A). A large proportion of dimension stone is transported overseas by ship for cutting and finishing. Dimension stone is used in monuments, statuary, flooring, stairs, and the decorative cladding of buildings. Dimension stone used in buildings must meet standards (set by the American Society for Testing and Materials) for absorption, bulk specific gravity, modulus of rupture, compressive strength, and resistance to abrasion (Panagapko, 2003). In other words, a good building stone is dense, strong, hard, and not porous. "Soundness or freedom from flaws is one of the most critical factors in evaluating a dimension stone deposit and one of the most difficult to determine" (Power, 1994, p. 1000). Failure to eliminate stone of inferior quality at the quarry can hasten structures' deterioration (fig. 47B,C).

Early Denver buildings typically were faced with locally quarried granite, rhyolite tuff, marble, travertine, or sandstone (Murphy, 1995). Sandstone, marble, and granite are still quarried in Colorado for use as dimension stone.

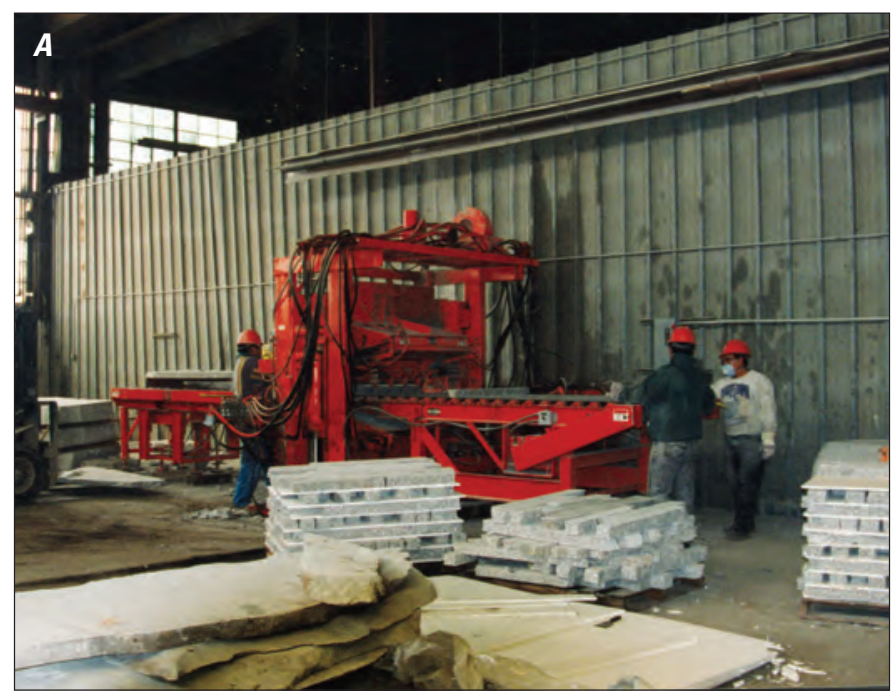

Figure 47. Dimension stone being processed or in use. It is required in new construction and later as replacement material. $A$, Granite processing at a plant near Salt Lake City, Utah. Photograph by William Langer. B, Ivy Chapel, Fairmount Cemetery, Denver, Colo. Natural weathering is one of the greatest threats to historic buildings. In 1890 , building material of unknown origin was used to construct this chapel. $C$, Weathered building material at the front entrance of Ivy Chapel, 2005. Paint was applied in an attempt to slow decay. Photographs $B$ and $C$ by $D$. Knepper, Jr.

\section{Classification by Rock Groups}

\section{Granite and Rhyolite}

Granite is an intrusive igneous rock that solidified slowly at great depth; it is composed principally of coarse crystals of quartz, feldspar, mica and, usually, hornblende. The term granite is from the Italian granire, to granulate, and the Latin granum, grain (Merriam-Webster, 2009). It is an excellent building material because it can withstand thousands of pounds of pressure and weathers slowly (fig. 48) (U.S. Geological Survey, 2003b). Most fresh, unweathered granite can be cut into usable building stone, but some colors, textures, and crystal sizes are more attractive than others and some granite is more uniform and yields larger volumes of homogeneous stone. The term rhyolite is from the Greek rhyax, meaning stream of lava (Merriam-Webster, 2009). Rhyolite is the fine-grained equivalent of granite; an extrusive igneous rock, it cooled rapidly at the Earth's surface. Rhyolite is also rich in silica and aluminum.
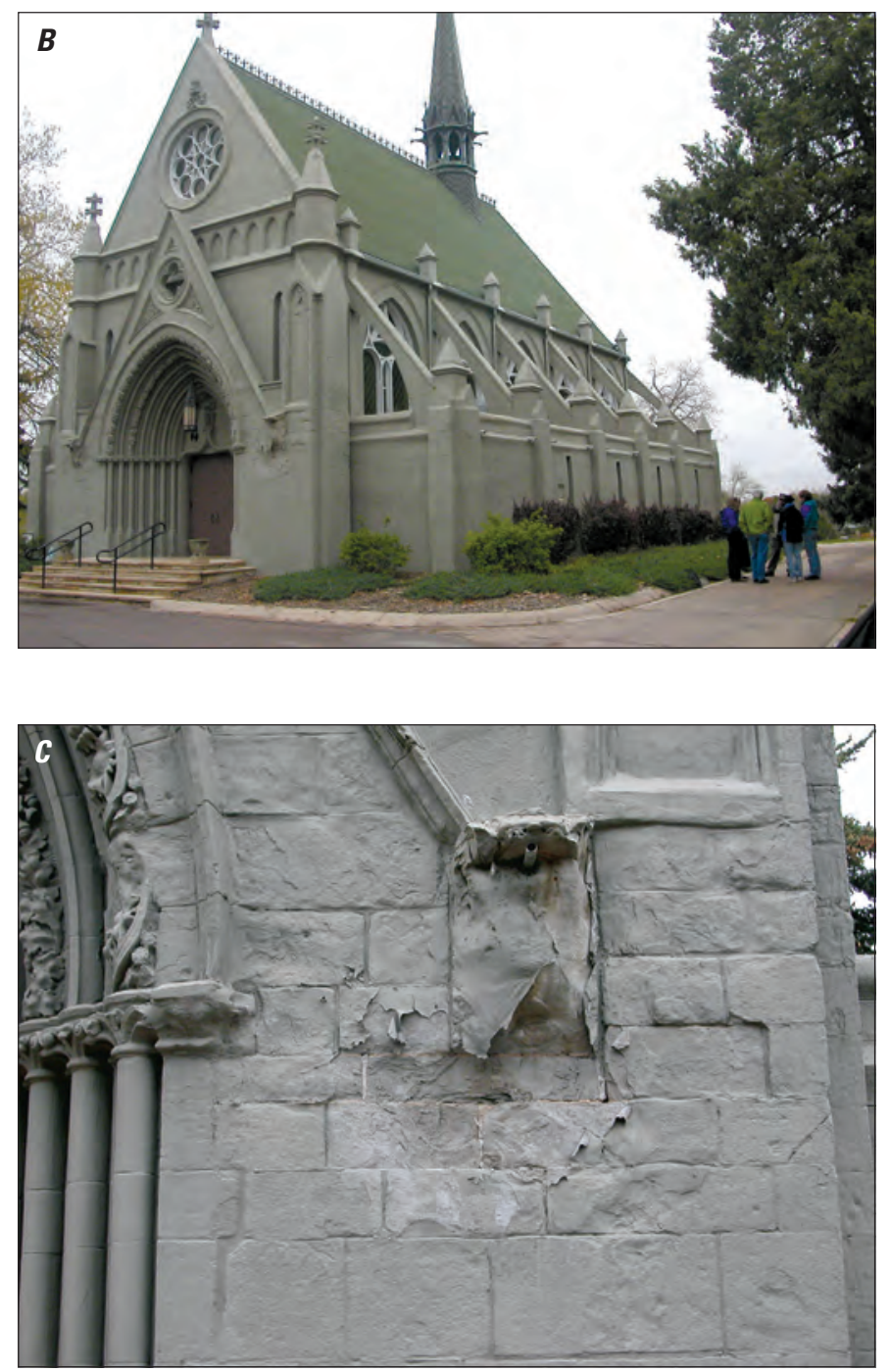


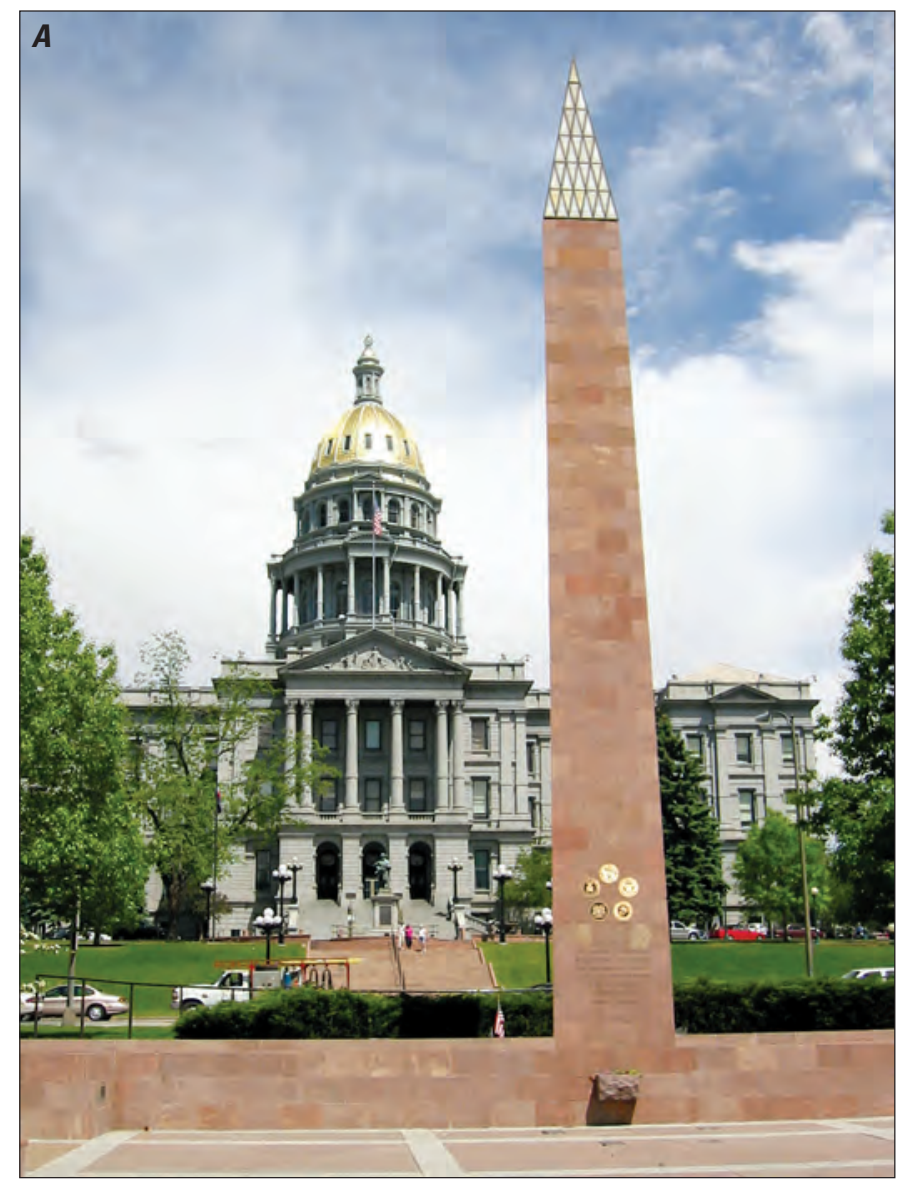

\section{Marble and Travertine}

Commercially, marble is a rock composed primarily of calcium carbonate $\left(\mathrm{CaCO}_{3}\right.$, calcite), dolomite $\left(\mathrm{CaMg}\left(\mathrm{CO}_{3}\right)_{2}\right)$, or serpentine (a hydrated calcium, magnesium, and silica oxide) that is capable of taking a polish (Power, 1994). Marble commonly is a crystalline, compact metamorphosed limestone. Although marble is abundant throughout the world, very few deposits are of high enough quality to be quarried (Sinkankas, 1988). The Beulah marble of Pueblo County was used on the interior walls and pillars of the Colorado State Capital building (Keller and Widmann, 2002). Yule marble, a lustrous, pure white marble quarried near the community of Marble, in Gunnison County, is the Colorado State rock (fig. 49). It is used as facing stone in the Lincoln Memorial and the Tomb of

Figure 48. Granite used to face buildings in Denver, Colo., and in outcrop. Granite is one of the oldest and most durable building materials. A, Gray granite from the Aberdeen Quarry, South Beaver Creek, Gunnison County, was used to construct the Colorado State Capitol in 1888. The War Memorial in the foreground constructed from Colorado sandstone. Photograph by John Keller, Colorado Geological Survey. $B$, Sketch of granite dikes in black schistose rock, Colorado. By W.H. Holmes, 1873. U.S. Geological and Geographical Survey of the Territories (Hayden Survey) Sheet 15. Courtesy of USGS Photographic Library.

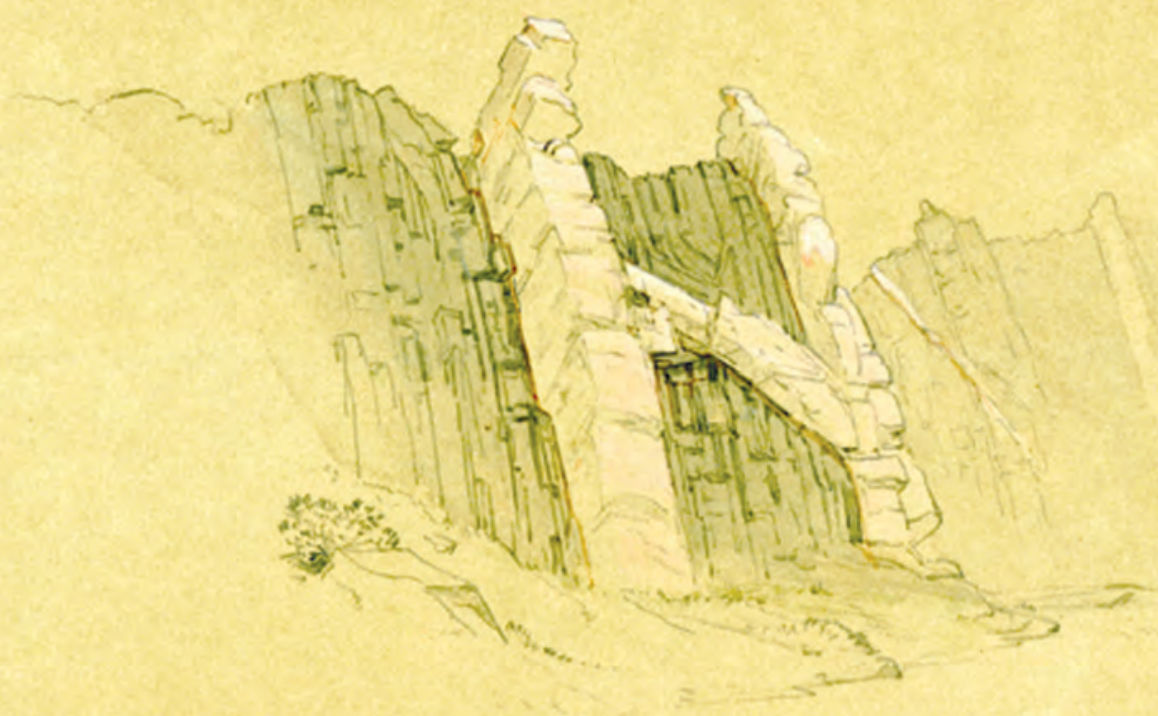



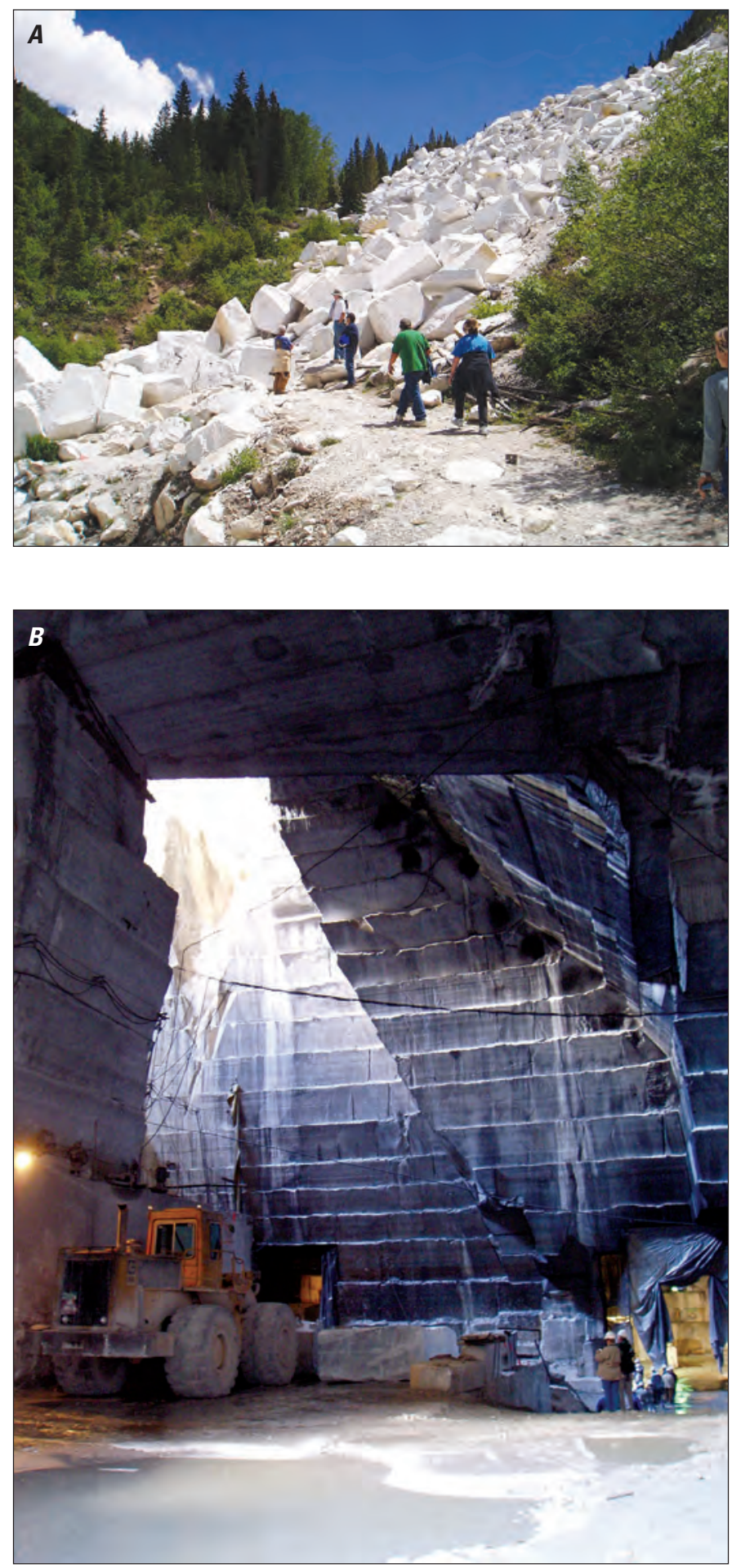

Figure 49. Yule marble quarry. Yule marble is prized world wide for its high quality and white color. $A$, Marble blocks outside quarry area, Gunnison County, Colo. $B$, Interior space of the Yule marble quarry. The walls of the quarry show saw marks made as stone was extracted. Photographs by John Keller, Colorado Geological Survey. the Unknown Soldier in Washington, D.C., in municipal buildings in New York City and San Francisco, and in the central post office and Federal Reserve Bank in downtown Denver (Pearl, 1972).

Travertine is a variety of limestone formed by precipitation of calcite from mineralized spring water, commonly hot or warm. Commercially valuable travertine is hard and dense, and banding and streaking of colors and textures make it an attractive building stone. Travertine deposits in central Colorado are relatively small, but the stone has been widely used in buildings in Colorado and elsewhere (Keller and Widmann, 2002).

\section{Sandstone}

Sandstone is a sedimentary rock composed of sandsized grains (usually fragments of quartz) cemented by clay, silica, carbonate, or iron oxide (fig. 50). The most widely used dimension stone in Colorado is the tan to reddishbrown flagstone mined from the Permian Lyons Sandstone in Boulder and Larimer Counties. Many of the buildings at the University of Colorado in Boulder were built with Lyons Sandstone, as well as many buildings, patios, walls, and other structures in the metropolitan Denver area. Although not as popular as the Lyons Sandstone, the Cretaceous Dakota Sandstone and the Ordovician Harding Sandstone have been used locally as building stone.

\section{Slate}

Rocks composed of cemented particles finer than sand are called shales. Slate is the harder metamorphic equivalent of shale (Sinkankas, 1988). It splits readily into slabs and is used for roofing and pavements. "Beds of differing composition that form color stripes on cleaved surfaces are called ribbons" and are considered deleterious in high-grade slate (Power, 1994, p. 992).

\section{Geology of Colorado Dimension Stone Deposits}

Heat that emanated from nearby shallow intrusive igneous rocks recrystallized Mississippian limestone and dolomite strata, thus forming the marble near Marble, Colo. A thick travertine deposit has been quarried at Wellsville (east of Salida) in Fremont County (Murphy, 1995). Deposits near Cañon City are capable of supplying large amounts of specimen travertine and have furnished large blocks for Federal buildings throughout the country (Pearl, 1972).

Granite, a common coarse-grained, colorful, intrusive igneous rock, is widely used as dimension stone. Several common granites in central Colorado have been quarried for building stone, including the large bodies of the Pikes Peak and Silver Plume granite (fig. 51). Along the Front Range, large masses of gray or pink Precambrian granitic rocks can be found west of Boulder, near Silver Plume (Clear Creek County) (Murphy, 1995). 

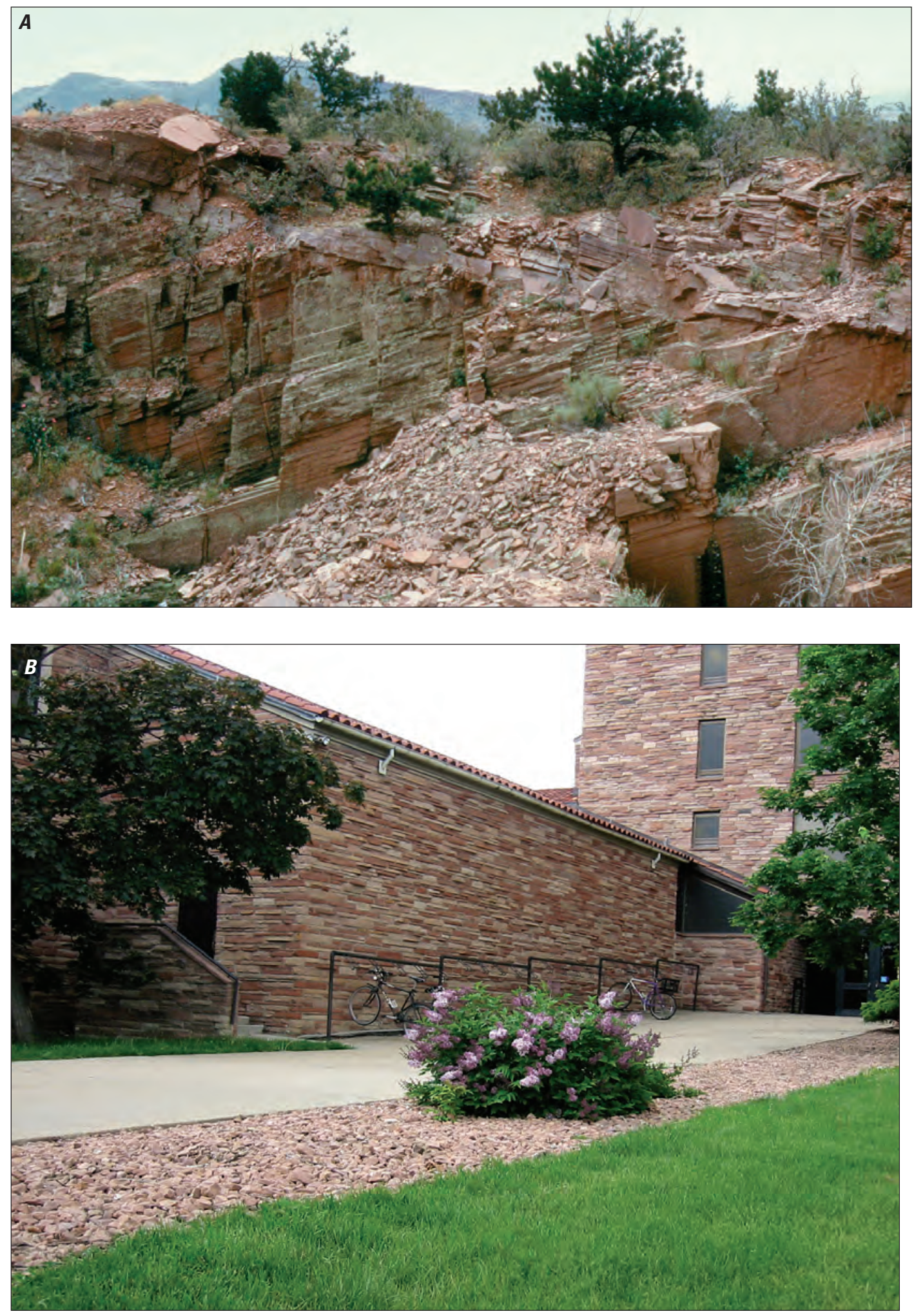

Figure 50. Multicolored Lyons sandstone in outcrop and in use. A, Lyons sandstone outcrops on the east side of Colorado's Front Range. Photograph by E.D. McKee. Courtesy of USGS Photographic Library. B, Building on the University of Colorado campus, Boulder. Sandstone from the Lyons Formation in Boulder and Larimer Counties used to construct most buildings on this campus. Cement sidewalk (made from limestone, sandstone, and aggregate) and decorative crushed stone in foreground. Photograph by Beth Widmann. 


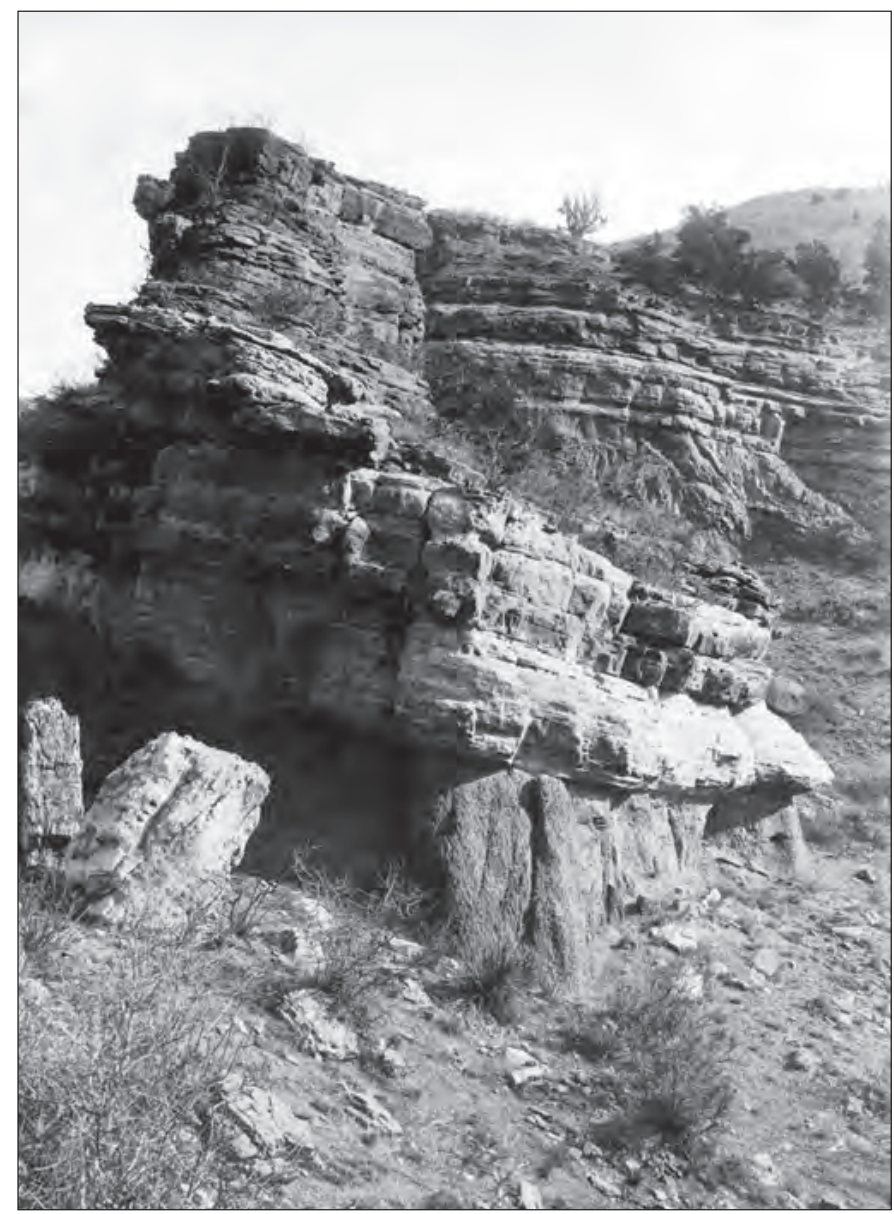

Figure 51. Sawatch Quartzite resting on smooth erosional surface on Pikes Peak Granite. Ute Pass, near Manitou Springs, El Paso County, Colo., 1914. Photograph by N.H. Darton. Courtesy of USGS Photographic Library.

The Wall Mountain Tuff (called Castle Rock Rhyolite in the mineral industry) is used as dimension stone in central Colorado. It is an eruptive volcanic rock with the same chemical composition as granite. The tuff was erupted as superheated, gas-charged lava and ash that moved rapidly across the countryside. When the superheated lava and ash came to rest, the materials welded together and formed a dense, hard stone suitable for construction. High-quality rhyolite tuff is quarried from mesa tops in the Castle Rock area, Douglas County (Murphy, 1995).

\section{Mining and Production}

Dimension stone may be extracted from above or below ground. Ornamental, building, and statuary stone is extracted by use of minimal blasting and then cut, processed, and transported with care to prevent damage.

Quarrying methods may use various combinations of diamond saws, wire saws, chain saws, channeling and drilling machines, wedges, and broaching tools (used to remove blocks after drilling a row of holes) to isolate a mass of rock by cutting it free from the main mass on all sides but one. The isolated block is then lifted or separated from the parent mass by breaking it free with wedges, high-pressure air or water bags, or by undercutting it with a wire or chain saw. First-cut blocks tend to be massive and may be several tens of feet long, as much as $6 \mathrm{~m}(20 \mathrm{ft})$ high, and less than $3 \mathrm{~m}$ (10 ft) wide. These massive quarried blocks are then subdivided into smaller blocks of a certain size and shape that can be sold or sent to a mill for further finishing. Explosives may be used to access different or higher grade parts of the deposit but are other-wise rarely used because they can damage the structural integrity of the stone.

Processing may produce specialty surfaces such as those that are polished or have a roughened flame texture; tumbling, leaching, scabbing (shaping and squaring of blocks for shipping and storage), and sandblasting may also be needed (Barker and Austin, 1994). The large quantities of dust produced during the mining, quarrying, and processing of dimension stone can be controlled by moist methods or by exhaust ventilation (Stellman, 1998).

In 2003, Colorado produced 4,600 tons of dimension stone (Beth Widmann, Colorado Geological Survey, written commun., 2006). In 2004, it produced about 5,800 tons valued at $\$ 1.5$ million (Cappa and others, 2004).

\section{Feldspar and Mica}

The word feldspar comes from the German feld, meaning field, and spath meaning any of various nonmetallic but usually cleavable and lustrous minerals (Merriam-Webster, 2009). Feldspar is not a mineral with a single chemical composition but rather a group of related minerals of similar structure whose composition varies: its formula is $\mathrm{MAl}(\mathrm{AlSi})_{3} \mathrm{O}_{8}$, where $\mathrm{M}$ may be $\mathrm{K}, \mathrm{Na}$, Ca, $\mathrm{Ba}, \mathrm{Rb}, \mathrm{Sr}$, or Fe (Bates and Jackson, 1987). Feldspar is abundant in rocks in the Earth's crust and in coarsegrained bodies (pegmatites) associated with granitic igneous rocks. In 2004, seventy percent of domestic feldspar was used in glass manufacture (Potter, 2005). Feldspar provides alumina that increases the hardness, durability, and resistance to chemical corrosion of ceramic and glass products. Rarely, feldspar forms large, bright bluish-green, gem-quality crystals called amazonite (Austin, 1995). Amazonite is found at a few places in the Precambrian Pikes Peak Granite in central Colorado (Eckel, 1961); it is prized by mineral collectors.

The term mica is akin to the Greek word micros, meaning small and the Latin word micare, to gleam or sparkle (Stellman, 1998; Merriam-Webster, 2009). The micas are a group of crystalline phyllosilicate minerals possessing platy habit, excellent cleavage, and resistance to heat. Natural mica is most commonly found in the form of flakes, scales, shreds, and books (books split into thin sheets) (fig. 52). 

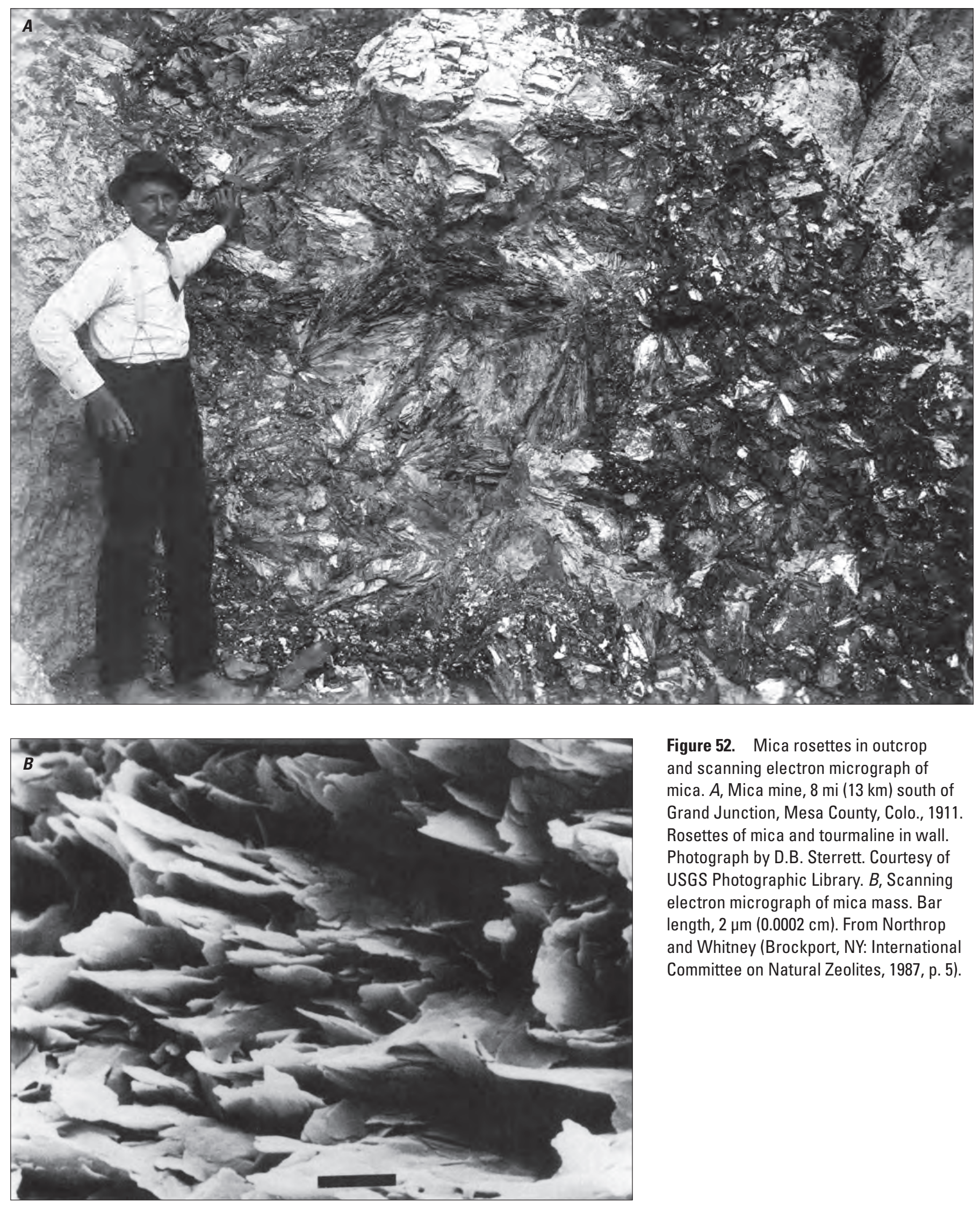

Figure 52. Mica rosettes in outcrop and scanning electron micrograph of mica. $A$, Mica mine, $8 \mathrm{mi}(13 \mathrm{~km})$ south of Grand Junction, Mesa County, Colo., 1911. Rosettes of mica and tourmaline in wall. Photograph by D.B. Sterrett. Courtesy of USGS Photographic Library. $B$, Scanning electron micrograph of mica mass. Bar length, $2 \mu \mathrm{m}(0.0002 \mathrm{~cm})$. From Northrop and Whitney (Brockport, NY: International Committee on Natural Zeolites, 1987, p. 5). 
Thin sheets of mica called isinglass, taken from large crystals that occur in extremely coarse grained granitic rocks (pegmatites), were once used as windows in ovens and gas lanterns because of mica's translucence and resistance to heat. Today it is used principally in the electronic and electrical industries, which import most sheet mica because of the higher cost to mine and process it in the United Sates (Hedrick, 2004). Built-up mica is produced by overlapping mica sheets and alternate layers of binders, then pressing them under high heat; it is used as an insulating material (for example, between copper wires or in electric motors).

Scrap mica is a byproduct of the beneficiation of feldspar, kaolin, and industrial sand, a reversal of earlier times when feldspar was considered waste in the search for mica (Anglin, 2002; Hedrick, 2004). Mines that produce pure, high-quality mica also produce feldspathic sand (used for stucco and golf course sand) as a byproduct.

The majority of domestic scrap and flake mica is ground to a coarse powder (Hedrick, 2004) that is used as a filler and reinforcement in plastics, joint compound, additive in oil-well mud, paint, roofing felts, and rubber products.

\section{Geology of Colorado Feldspar and Mica Deposits}

In central Colorado, feldspar and mica have been produced from several Precambrian pegmatites. Pegmatites are relatively small igneous bodies of granitic composition distinguished by their extremely large crystals; it is not unusual to find individual crystals in pegmatites measured in feet. They form during the late, relatively water-rich stages of crystallization of large bodies (batholiths) of granitic rocks. Such large granite bodies were emplaced in Proterozoic metamorphic country rocks of central Colorado: the Routt Plutonic Suite, which includes the Boulder Creek Granite, 1.7 billion years ago (Ga); the Berthoud Plutonic Suite, which includes the Silver Plume Granite, $1.4 \mathrm{Ga}$, and the granitic rocks of the Pikes Peak batholith,1.0 Ga (Tweto, 1987). The pegmatites lie within the batholithic rocks and in the metamorphic country rocks (Lovering and Goddard, 1950).

The essential minerals in pegmatites are potassium feldspar (microcline) and quartz. Common accessory minerals include muscovite, biotite, plagioclase, and other minerals found in granites. In addition, pegmatites may contain beryl, columbitetantalite, lepidolite, topaz, tourmaline, and other exotic minerals but generally not in commercial quantities. Although the shapes of pegmatite bodies are highly irregular, they usually have a broad concentric zoning: the core contains very coarse grained microcline or quartz, or both; an intermediate zone of less coarse grained muscovite and albite plagioclase, and an outer zone of even less coarse grained quartz, potassium feldspar, and muscovite (Lovering and Goddard, 1950). In iron-rich pegmatites emplaced in the Pikes Peak batholith, iron-bearing biotite mica crystallized instead of muscovite (Simmons and Heinrich, 1980). The once commercially valuable deposits of feldspar and mica came primarily from the core and intermediate zones of the pegmatites (Vanderwilt, 1947).

\section{Mining and Production}

Conventional open-pit mining methods and some hydraulic dredging are used to remove overburden and to drill, blast, and haul feldspar ore, which then is crushed. A froth flotation process is commonly used to concentrate feldspar (U.S. Environmental Protection Agency, 1995c). An amine collector floats off mica after sulfuric acid, pine oil, and fuel oil are added. After dewatering the discharge (usually by rotary dryers), sulfuric acid is added to lower the $\mathrm{pH}$ and petroleum sulfonate is added to remove iron-bearing minerals. Magnetic separation may be used to remove any iron minerals. The discharge is dewatered again, and a cationic amine is used for collection as the feldspar is floated away from quartz in hydrofluoric acid. Further milling and refining may be necessary depending upon its end use. Feldspar is ground to about 20 mesh for glassmaking and to 200 mesh or finer for most ceramic and filler applications. Some processors are able to recover mica and silica sand from feldspar ores (Potter, 2005).

To reduce the environmental and health concerns of working with acids, new flotation reagents are being tested (in 2005) as are high-intensity magnetic separators. The primary pollutant of concern that is emitted from feldspar processing is particulate matter (U.S. Environmental Protection Agency, 1995c). Health hazards posed by this particulate matter may include exposure to substantial amounts of free silica (Stellman, 1998).

Although flake mica is mined by conventional open-pit methods, sheet mica typically is mined by the hard-rock mining techniques of drilling and blasting. Sheet mica is quarried by open pit or underground mining, which requires careful blasting to keep the crystals intact. The mined crystals are trimmed of rock (cobbed) and sorted by thickness and quality into blocks, thin leaves (splittings), and scrap. Dry grinding or dewatering, pneumatic separation, and screening may follow. Mica scrap is ground into mica flakes or powder.

Static electricity can be generated during the processing of mica; engineering techniques can discharge it harmlessly. Dusts that contain quartz, feldspar, and silicates are generated and must be controlled (Stellman, 1998). No environmental concerns are associated with the manufacture and use of mica products (Hedrick, 2004).

Feldspar and mica are not presently mined in Colorado (John Keller, Colorado Geological Survey, oral commun., 2006).

\section{Sulfur}

The term sulfur is from the Latin sulpur and Middle English sulphur, meaning brimstone, "the stone that burns" (Merriam-Webster, 2009). Early humans used sulfur as a colorant for cave drawings and as a fumigant, the Egyptians used it to bleach fabrics as early as 2000 B.C.E., and the ancient Greeks used sulfur in warfare to produce suffocating gases and as a disinfectant (Wilburn and others, 2001; Ober, 2002). Sulfur was also important because of its use in early gunpowder, discovered by the Chinese in the 9th century (Buchanan, 2006). 
Today, 90 percent of sulfur in the United States is converted to sulfuric acid $\left(\mathrm{H}_{2} \mathrm{SO}_{4}\right)$ for the processing of phosphate rock into phosphoric acid $\left(\mathrm{H}_{3} \mathrm{PO}_{4}\right)$ and other phosphate fertilizers, in petroleum refining, and in metal industry processes (Ober, 2004). Sulfur is also used in rubber, insecticides, medicine for skin diseases, and pellets for direct application as an agricultural soil supplement.

In 1996, the Louisiana Department of Wildlife and Fisheries created the world's largest artificial reef from the Freeport sulfur mine off Grand Isle, La. (Kasprzak, 2000) (fig. 53). The mile-long sulfur mine platform (including bridge supports) provides habitat to many coastal fishes. Annually, the Department's marine laboratory staff attaches recreational mooring buoys to the sulfur mine reef site.

\section{Geology of Colorado Sulfur Deposits}

Sulfur is abundant in central Colorado, but very little has actually been produced. Most of the sulfur is in sulfide and sulfate minerals and in deposits of petroleum and natural gas. The abundant hydrothermal mineral deposits of Colorado contain sulfide minerals of $\mathrm{Pb}, \mathrm{Zn}, \mathrm{Fe}, \mathrm{Cu}$, and $\mathrm{Mo}$. In the past, smelters produced unwanted sulfur as a waste byproduct of processing these ores. The natural oxidation of sulfide minerals releases sulfur into water moving through sulfide-rich deposits, producing sulfuric acid, or through the mine workings of the exploited deposits, producing acid mine drainage. A second source is the large quantity of sulfur locked up in the voluminous sedimentary deposits of gypsum and anhydrite in evaporite deposits of late Paleozoic and Mesozoic age in central Colorado.

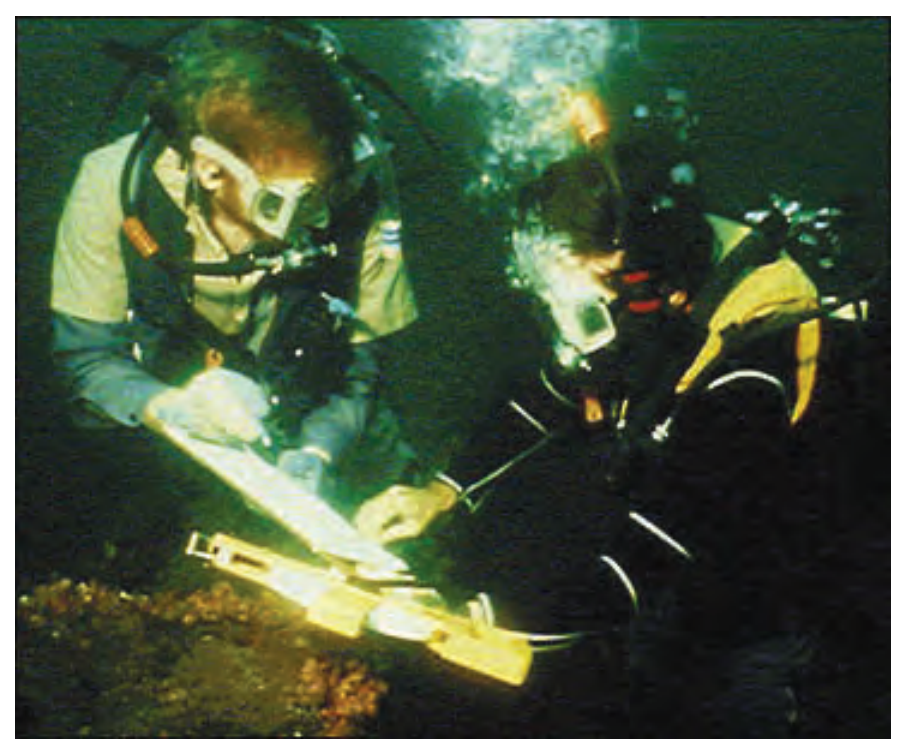

Figure 53. Scientists record data on the biota of an artificial reef. Courtesy of Louisiana Department of Wildlife and Fisheries.

\section{Mining and Production}

Sulfur and sulfuric acid are produced from three sources: combined sulfur, recovered sulfur, and formed sulfur (U.S. Environmental Protection Agency, 2002). Combined sulfur occurs in minerals such as iron pyrite $\left(\mathrm{FeS}_{2}\right)$, copper sulfides, and gypsum (calcium sulfate). Combined sulfur can be recovered from sulfur dioxide emissions produced during the smelting of metal sulfides (U.S. Environmental Protection Agency, 2002). Recovered sulfur is produced — and then captured — as a byproduct of oil refining, natural gas processing, and air pollution control. Formed sulfur is elemental sulfur cast or pressed into particular shapes.

Sulfur is mined by underground, surface, and Frasch mining methods. Open pit and underground mining extract elemental sulfur and pyrite deposits not amenable to the Frasch process. High- to medium-grade ore from these deposits can be roasted and the resulting $\mathrm{SO}_{2}$ gas converted to sulfuric acid. To produce elemental sulfur, low-grade ores are treated by processes such as direct melting, distillation, agglomeration, solvent extraction, and flotation.

The Frasch process, a solution mining method, was used to extract underground deposits of sulfur such as those in limestones around the Gulf of Mexico. A mixture of compressed air and superheated water was pumped into deposits containing sulfur. The hot water melted the sulfur and the pressurized air drove the liquid sulfur to the surface. The liquid sulfur was treated to remove organic impurities and then either was sold as a liquid or cooled and solidified for the market. Domestic mining of elemental sulfur by use of the Frasch process ended in 2000 because of environmental concerns; all sulfur now produced in the United States is recovered from the refining of sulfur-bearing natural gas and crude petroleum and from coking plants (Ober, 2002).

The Claus process, which uses thermal and catalyticconversion reactions, was the first process for recovering sulfur from hydrogen sulfide $\left(\mathrm{H}_{2} \mathrm{~S}\right)$ in oil and gas production (Wilburn and others, 2001). Sulfur is considered a sustainable industrial mineral for the foreseeable future, and recovered sulfur tonnages are expected to continue from petroleum refineries, as sulfur emissions are strictly controlled by government regulations (Ober, 2004).

\section{Barite}

The term barite comes from the Greek barites, meaning weight (Merriam-Webster, 2009). Barite, the principle ore of barium, is a heavy, nonmetallic mineral consisting of barium sulfate $\left(\mathrm{BaSO}_{4}\right)$. Barite is relatively insoluble, a property that keeps the heavy metal barium $(\mathrm{Ba})$ from entering surface waters (Hammarstrom and Smith, 2002).

About 95 percent of barite in the United States is used as a weighting agent in gas-well and oil-well drilling fluids (Searls, 2004). Pulverized barite is added to the drilling fluid (a clay-water mixture called mud) to control the escape of gas from the reservoir and prevent blowouts (Bates, 1969). 
Barium compounds are also used in medical x-ray examinations, automobile brake and clutch pads, golf and tennis balls, optical glassware, radiation shields around nuclear reactors, faceplates for television sets and computer monitors, and cement vessels that contain radioactive materials (Searls, 2004).

Beginning in 1981, importing ore from overseas sources became less expensive than extracting, processing barite ore, and shipping it long distances in the United States. Twentyseven years later, however, increased oil-field drilling and a shortage of inexpensive foreign ores could make barite an economically attractive mineral commodity again (Arkansas Geological Survey, 2009). In 2005, 82 percent of the barite used in the United States was imported (U.S. Geological Survey, 2006).

\section{Geology of Colorado Barite Deposits}

Barite occurs as a gangue (undesired part of an ore) mineral in some hydrothermal veins associated with base and precious metal deposits in central Colorado, especially within the Colorado mineral belt. The veins cut Cretaceous and Tertiary plutons, nearby Precambrian igneous or metamorphic rocks, or Paleozoic country rocks. However, none of these hydrothermally altered country rocks contain barite in a quantity that can be mined economically today.

In the northern Wet Mountains, barite occurs in quartzbarite-thorite veins and fracture zones associated with the intrusion of alkalic rocks of the Gem Park area, including the McClure Mountain and Democratic Creek complexes and associated dikes (Armbrustmacher, 1988). The age of these rocks is about $520 \mathrm{Ma}$, or Early Cambrian (Olsen and others, 1977). The veins and fracture zones cut Proterozoic igneous and metamorphic rocks as well as the Cambrian alkalic rocks of the complexes.

Barite occurs at the surface today in tailings at abandoned mines in Boulder County, in the Wet Mountains, and probably in many other mine dumps in the region. Barite crystals have been found on Federal land (Pawnee National Grassland) and throughout a wide region of Weld and Logan Counties (Workman, 1964). Most of the barite crystals are on State and privately owned land (P. Modreski, U.S. Geological Survey, oral commun., 2004). Of note are the large blue barite crystals found southwest of Hartsel, Park County, Colo. (Pearl, 1972).

\section{Mining and Production}

Barite ore is crushed and stockpiled. Some barite ores are ground to the user's specifications (Brobst, 1994); barite from other deposits may be washed and separated by various techniques-moving screens up and down in water, heavy media, tabling, flotation, and magnetic (Searls, 2003).

"The barite industry has no especially difficult ecological problems other than those attendant upon the mining and beneficiation of ores [for example, water quality and dust suppression]" (Brobst, 1994, p. 132). Although barite contains the heavy metal barium it is not thought to be toxic, as defined in Section 313 of the Emergency Planning and Community Rightto-Know Act of 1986, owing to its insolubility (Searls, 2003).

Barite is not presently mined in Colorado (John Keller, Colorado Geological Survey, oral commun., 2006).

\section{Diamonds, Gemstones, and Mineral Specimens}

Gemstones are minerals or other natural materials (such as pearl, amber, and coral) with superior color and clarity that are durable for ornamental purposes. "Collector or specialty gems are rare, unusual, or unique gems that are not normally seen by the gem buying public. The stones may be gem materials that are common to the market place, but are unusual or unique because of their large size or unusual color" (Austin, 1995, p. 7). They range in value from a few tens of dollars per carat to more than $\$ 1,000$ per carat.

Although gems are not usually considered industrial minerals, certain gem minerals, such as diamond or garnet that do not meet gem standards may be used primarily as abrasives and are termed "industrial." In addition, some mineral specimens have economic value. "Aside from a few regions such as the Alps of Europe or the granite areas of Colorado west of Colorado Springs * ** virtually all [mineral] specimens enter the market as byproducts of mines operated for metallic ores or industrial or gem minerals" (Sinkankas, 1988, p. 328). Specimens are sold mostly to tourists, museums, schools, and private collectors domestically and abroad (Arkansas Geological Survey, 2009). Collecting mineral specimens is a popular recreation activity (fig. 54).

Gemstones found in Colorado that are of commercial importance include amazonite, aquamarine, diamond, gypsum (fine-grained alabaster and fibrous satin spar types), lazurite, several varieties of quartz, rhodochrosite, topaz, and turquoise (Scott, 1964; Murphy and Modreski, 2002). Colorado's quartz gemstones include fine quality jasper, agate, petrified wood, and agatized dinosaur bone on both sides of the Continental Divide (Austin, 1995).

Diverse gemstones and mineral specimens can be collected in Colorado. Edwin Eckel's book, "Minerals of Colorado," (1997), describes the chief occurrences of all known or reported Colorado minerals; refer to it for additional localities. Many of Colorado's prolific mineral localities are on public land (Pearl, 1972). A number of examples are given below.

\section{Classification by Mineral Variety}

\section{Amazonite}

Amazonite (or amazonstone) is a green to blue-green variety of the mineral microcline $\left(\mathrm{KAlSi}_{3} \mathrm{O}_{8}\right.$, potassium feldspar); it is commonly mistaken for jade. It is fairly hard (Mohs hardness of 6-6.5). The Pikes Peak region is an important source of amazonite, smoky quartz, topaz, and 

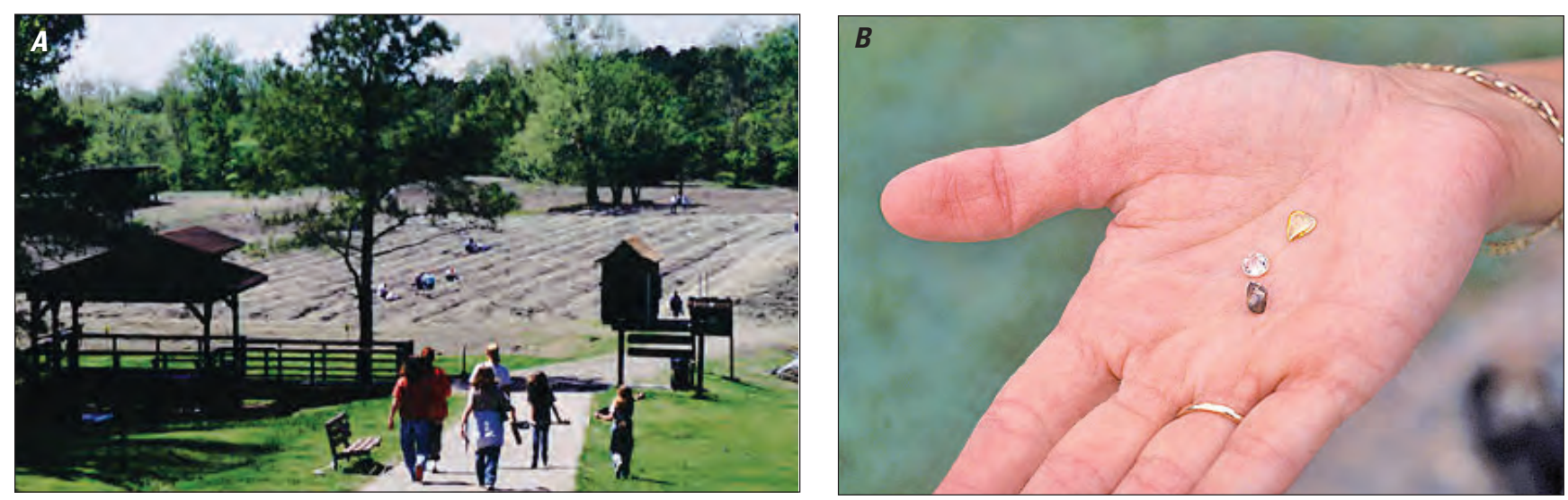

Figure 54. Crater of Diamonds State Park, near Murfreesboro, Ark. A, Prospectors of all ages at this tourist attraction access the diamond search area through the park visitor center. Here interpretive exhibits and an audiovisual program explain the area's geology and give tips on recognizing diamonds in the rough. $B$, Diamonds from the State park; they can be any color in the rainbow. Raw diamonds have a shiny metallic look. Courtesy of Crater of Diamonds State Park.
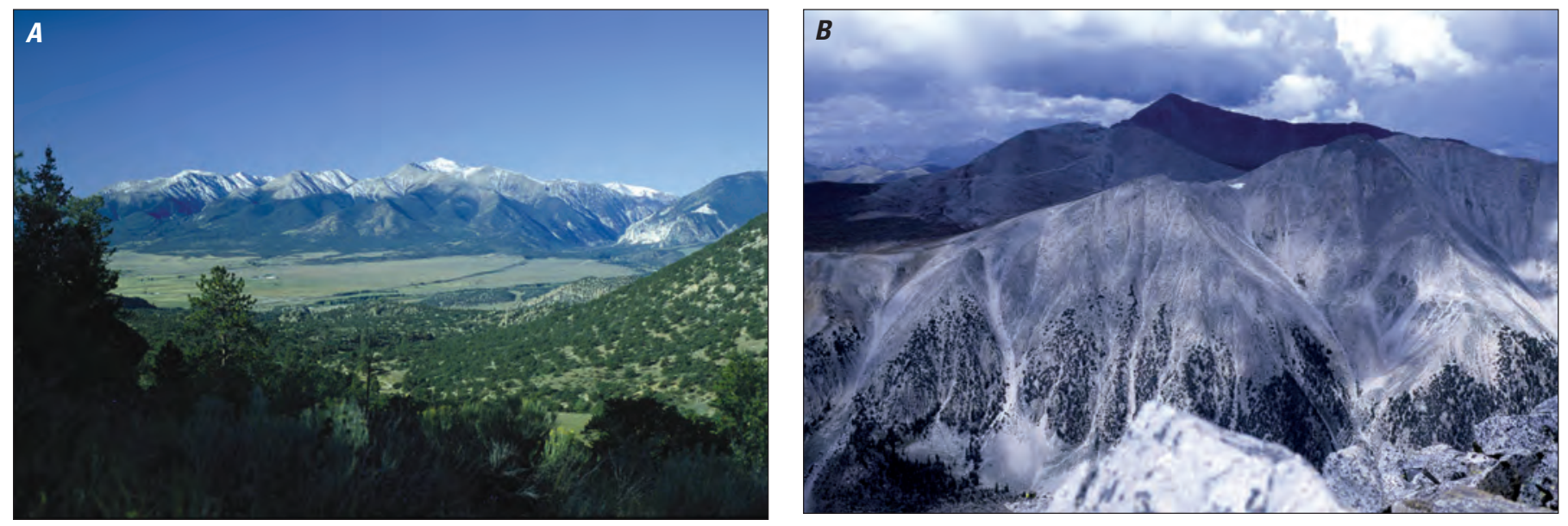

Figure 55. The Sawatch Range, southern Colorado Rocky Mountains, is famous for gems and views. $A$, Sawatch Mountains.

$B$, Close-up of the Mount Antero-Mount White area, Chaffee County, Colo. The area is known for its mineral resources. Photographs by Jim Shannon. Courtesy of Colorado School of Mines.

amethyst (Pearl, 1972). The region includes the Crystal Peak area in Park and Teller Counties (north of Florissant) and along the Tarryall Mountains from Topaz Mountain to Tappan Mountain (west of Manitou Springs, El Paso County) (Pearl, 1972; Murphy and Modreski, 2002). The Crystal Peak area “*** is the most productive source of gem and specimen quality amazonite in Colorado, if not in the world” (Eckel, 1997, p. 323).

\section{Apache Tears}

Small black stones of obsidian, called Apache tears, are natural volcanic siliceous glass formed by rapidly cooled magma. Obsidian has a Mohs hardness of 5.0-5.5. Stone-age people sought obsidian for its ability to break and give sharpedged tools. Today, the stones are used in the souvenir trade.
Ruby Mountain, south of Buena Vista (Chaffee County), is popular with mineral collectors for its black obsidian, garnet, and topaz specimens.

\section{Aquamarine}

The term aquamarine is from the Latin aqua marina, meaning seawater (Merriam-Webster, 2009). It is a transparent blue, green, or blue-green gem variety of the mineral beryl $\left(\mathrm{Be}_{3} \mathrm{Al}_{2} \mathrm{Si}_{6} \mathrm{O}_{18}\right)$ with a Mohs hardness of 7.5-8. The color is caused by iron impurities. Aquamarine has been found in Egyptian and Greek tombs and is Colorado's official State gemstone. Aquamarine and smoky quartz are known to occur in the Mount Antero area (part of San Isabel National Forest) and Mount White area (in the Sawatch Range at about 4,300 m (14,000 ft) of central Chaffee County (fig. 55). 


\section{Diamond}

Diamond, one of the hardest materials known, is composed of pure crystalline carbon (C). Only about 20 percent of all diamonds mined meet gem standards. The rest are classified as natural industrial grade and used in tool and die stones, drilling material, grits, and powders (Reckling and others, 1994) and as heat sinks in electronic compounds, infrared windows in heat detectors, and surgical instruments (Arkansas Geological Survey, 2009). Synthetic manufactured diamonds have replaced more than 90 percent of the natural industrial diamonds once used in the United States (Olson, 2004b).

Primary diamond deposits are found in unusual igneous intrusive bodies known as kimberlite and lamproite pipes that formed at great depth, whereas secondary deposits are found in sand and gravel of alluvial streambeds. Mining of diamonds within the United States has been limited to Arkansas and to Larimer County in northern Colorado (Colorado Geological Survey, 1999).

\section{Gypsum}

The three mineral varieties of gypsum $\left(\mathrm{CaSO}_{4} \cdot 2 \mathrm{H}_{2} \mathrm{O}\right.$, calcium sulfate dihydrate) are all sought by mineral collectors: selenite is a colorless to translucent form with a pearl luster, satin spar has a fibrous, satiny look, and alabaster is a finegrained massive material. Selenite and satin spar are of less economic importance than alabaster (Bates, 1969). The largest alabaster quarry in the United States is located in eastern Larimer County, north of Fort Collins; alabaster is one of the Colorado ornamental minerals best known from a commercial standpoint (Pearl, 1972). Gypsum localities such as Coon Gulch, south of Golden, Jefferson County; Perry Park, Douglas County; and areas near Colorado Springs, El Paso County, are of interest to collectors (Eckel, 1997).

\section{Lazurite}

Lazurite is the blue component of the gemstone lapis lazuli, once used as the pigment ultramarine when ground to a powder for tempera and oil paint. The ancient city of Ur, near the Euphrates River in lower Iraq, had a thriving trade in lapis as early as 4,000 B.C.E. (Bancroft, 2000). Lazurite is a feldspathoid mineral of the sodalite group$(\mathrm{Na}, \mathrm{Ca})_{78}(\mathrm{Al}, \mathrm{Si})_{12}(\mathrm{O}, \mathrm{S})_{24}\left[\mathrm{SO}_{4}, \mathrm{Cl}_{2}(\mathrm{OH})_{2}\right]_{2}$ (Bates and Jackson, 1987). Lazurite occurs on Italian Mountain in the Sawatch Range, north of Crested Butte, Gunnison County, Colo., one of the few sources in the world of high quality lapis lazuli (Pearl, 1972; Eckel, 1997).

\section{Peridot}

Pliny tells of the first recorded peridot specimen, which was presented to a Theban queen of Lower Egypt about 300 B.C.E. (Bancroft, 2000). It is also known as the "evening emerald" and as chrysolite. Peridot is the transparent gem variety of a common rock-forming mineral called olivine. It is a magnesium iron silicate, $(\mathrm{Mg}, \mathrm{Fe})_{2} \mathrm{SiO}_{4}$, and has a Mohs hardness of 6.5-7. Peridot occurs within the San Isabel National Forest on a fairly remote basalt-capped mesa near the southwest edge of South Park (on the border of Fremont and Park Counties in the vicinity of Herring Park, Colo.) (Murphy and Modreski, 2002).

\section{Pyrite}

"Fools gold" is a common name for pyrite $\left(\mathrm{FeS}_{2}\right.$, iron sulfide), a shiny brass-yellow mineral with a Mohs hardness of 6-6.5. Pyrite was mined for its sulfur content during World War II. It is a common mineral, but unique pyrite clusters can be found near Florence, Fremont County, Colo.

Quartz

Cryptocrystalline quartz ( $\mathrm{SiO}_{2}$, silicon dioxide) includes chalcedony, agate, jasper, flint, hornstone, and chert. Around 2.5 million years ago, Paleolithic humans used flint to make tools. Agate and jasper are found throughout Colorado (Eckel, 1997). Gem quality or collectible crystalline quartz occurs in many varieties; Eckel (1997, p. 399-405) summarizes Colorado quartz occurrences.

- Rock-Colorless, found throughout the Colorado mineral belt and most abundantly in Chaffee, Ouray, and San Juan Counties (Eckel, 1997)

- Amethyst-Purple, a low- to moderate-temperature variety of quartz. Found in the Pikes Peak batholith (Douglas, Jefferson, El Paso, Park, and Teller Counties)

- Citrine-Yellow

- Rose-Colored by trace amounts of titanium, iron, or manganese. Found in Chaffee, Clear Creek, and Fremont Counties

- Smoky - Tan to brown to black coloring, formed through natural irradiation of clear quartz that contains aluminum. Found in granitic pegmatites in the Pikes Peak batholith and the Mount Antero Granite, including Chaffee, Douglas, Jefferson, El Paso, Park and Teller Counties

- Milky—Found in the San Juan region, Ouray County, southwestern Colorado

- Rutilated-Quartz that encloses needlelike crystals of rutile.

Topaz

Topaz $\left(\mathrm{Al}_{2} \mathrm{SiO}_{4}(\mathrm{~F}, \mathrm{OH})_{2}\right.$, an aluminum silicate mineral) (Eckel, 1997) has a hardness of 8 on the Mohs scale. The name topaz is incorrectly applied to citrine, which is yellow quartz. The best known sources of gem-quality topaz are pegmatites in the Pikes Peak batholith including Pike National Forest (the area of Devils Head, south of Sedalia, Douglas County); Harris Park, Park County; Crystal Peak 
(near Florissant), Teller County; Glen Cove, Teller County; and the Tarryall Mountains, Park County (Eckel, 1997). The Devils Head area offers more long-range possibilities for mineral collecting than any other place in Colorado, according to Pearl (1972).

\section{Rhodochrosite}

Rhodochrosite ( $\mathrm{MnCO}_{3}$, manganese carbonate), the Colorado State mineral, is a pink to red mineral, but its inherent softness (Mohs hardness 3.5-4.0) discourages its use in jewelry. It was mined by the Incas probably more than a thousand years ago in Argentina (Bancroft, 2000). It was once ground up for face powder, and in the early mining days of Colorado, miners discarded the red mineral as waste while they mined silver- and gold-bearing sulfide veins. Rhodochrosite is found in eighteen of Colorado's counties associated with gold, silver, lead, zinc, and molybdenum ores (Colorado Geological Survey, 2004b). Translucent red crystal specimens are prized the world over. One of the finest rhodochrosite sources was the Sweet Home mine in Park County, west of Alma (Austin, 1995; Murphy and Modreski, 2002) (fig. 56). The Sweet Home mine closed in 2004 after many years of operation.

\section{Turquoise}

Turquoise $\left(\mathrm{CuAl}_{6}\left(\mathrm{PO}_{4}\right)_{4}(\mathrm{OH})_{8} \cdot 4 \mathrm{H}_{2} \mathrm{O}\right.$, hydrated copper aluminum phosphate) is probably one of the oldest gemstones known, worn by pharaohs, Aztec kings, and Native Americans (Austin, 1995). The Anasazi and Hohokam mined turquoise

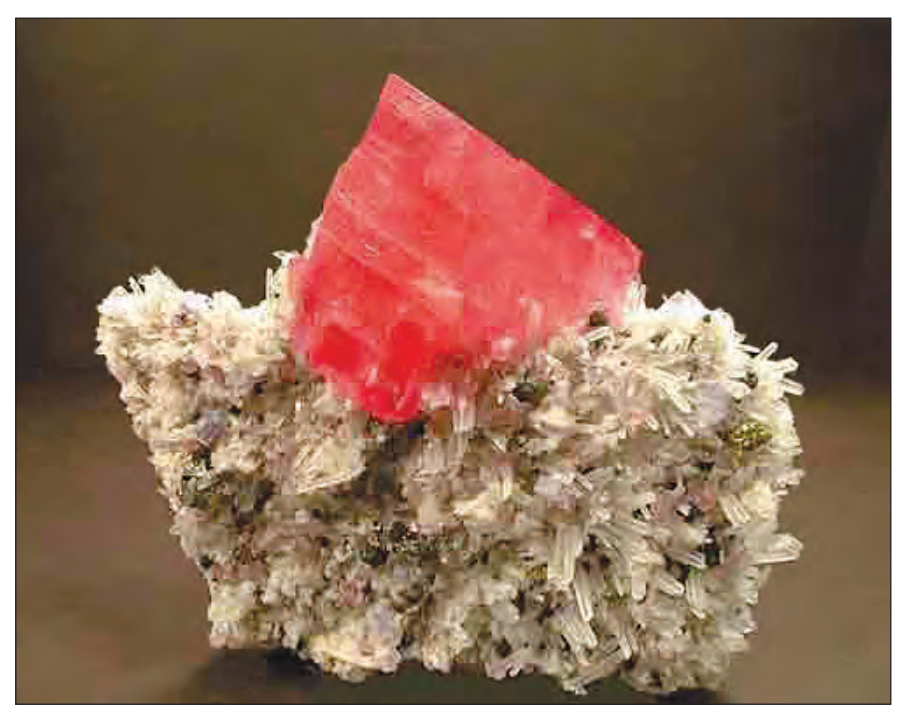

Figure 56. Specimen containing rhodochrosite (red), quartz (white), tetrahedrite (black), chalcopyrite (gold), and fluorite (pale purple). Sweet Home mine (formerly a silver mine), Alma, Colo.; specimen $8 \times 8 \mathrm{~cm}$. Courtesy of Fabre Minerals http://www.fabreminerals.com. Rhodochrosite is the official State mineral of Colorado. throughout the Southwest. Its Mohs hardness is 5-6. In the United States, the aluminum (Al) in "turquoise" is partially replaced by iron (Fe) and thus, strictly speaking, the mineral is chalcosiderite, not turquoise (Schumann, 2007). Turquoise has been recovered near Leadville, Lake and Eagle Counties; near Colorado Springs, El Paso County; and near Villa Grove, Saguache County (Austin, 1995). Although total production is small, turquoise is one of the most valuable gemstones produced in Colorado (Eckel, 1997).

\section{Geology of Colorado Gemstone and Hand Specimen Deposits}

The majority of Colorado's gemstone and crystal specimens is found in pegmatites rather than hydrothermal deposits (Murphy and Modreski, 2002). One exception, rhodochrosite, occurs in moderate- to low-temperature hydrothermal ore veins, particularly those containing silver, lead, zinc, and copper, as well as in high-temperature metamorphic deposits.

Crystal specimens of amazonite, aquamarine, beryl, and topaz are found in pegmatites in the Pikes Peak batholith, central Colorado, and are commonly accompanied by quartz, mica, and feldspar crystals. Pegmatites have the same basic mineralogic composition as granite but are extremely coarse grained. Pegmatites generally formed within a trapped pocket of magma that cooled very slowly in a relatively water-rich fluid that allowed very large crystals to form.

Lapis lazuli usually occurs in crystalline limestones as a result of contact metamorphism. Alabaster, like other forms of gypsum, forms by evaporation of seawater.

Pyrite forms large bodies in moderate- to high-temperature hydrothermal deposits and in contact metamorphic ore deposits, is an accessory in many igneous rocks, and is common in sedimentary beds and metamorphosed sediments.

Widespread deposits of petrified wood are found in the Tertiary Dawson Arkose throughout an area extending from south and east of Denver to the Black Forest area northeast of Colorado Springs, including parts Arapahoe, Douglas, Elbert, and El Paso Counties (Eckel, 1997).

Turquoise is formed by the percolation of groundwater through aluminous rock in the presence of copper. For this reason, it is often associated with copper deposits as a secondary mineral, most often in copper deposits in arid, semiarid, or desert environments (Austin, 1995).

Diamonds occur in an unusual igneous rock called kimberlite. Kimberlites are found in pipe-like structures extending from the upper part of the mantle through the crust to the surface. These pipes, called diatremes, are formed by the violent eruption of carbon dioxide $\left(\mathrm{CO}_{2}\right)$ in melted mantle (magma), which entrains pieces of mantle rock and crust (xenoliths) and crystals precipitated out of the melt (phenocrysts). Chunks of wall rock dragged into the mobile kimberlite magma contain rock types typical of the upper mantle (peridotite and eclogite, which may contain diamonds), of the lower crust (granitic and metamorphic rocks), and of the near-surface crust (sedimentary rocks entrained during 
an eruption). The most common mineral crystals found in unweathered kimberlite are ilmenite, garnet, olivine, clinopyroxene, and orthopyroxene. Alteration and weathering usually destroy most primary minerals and textures, producing a soft rock composed largely of secondary minerals such as serpentine, carbonate minerals, and iron and titanium minerals (Coopersmith and Schulze, 1996).

Kimberlite rocks were identified in the Colorado Front Range in 1965 near the Colorado-Wyoming border. Since then, about 100 kimberlite intrusions have been identified in the Front Range between Boulder, Colo., and southern Wyoming. It wasn't until 1975 that a diamond was discovered in a rock sample from one kimberlite near the Colorado-Wyoming State line. Approximately 40 kimberlite occurrences have since been identified in this area, known as the State Line kimberlite district (Colorado Geological Survey, 1999). Virtually all of the State Line kimberlites contain diamonds, but only the largest bodies in a cluster near Kelsey Lake have been mined commercially (Thompson, 1996).

\section{Mining and Production}

Overall, gemstone production in Colorado was estimated to be $\$ 359,000$ in 2004 (Cappa and others, 2004), an increase of 31 percent as compared with the 2003 estimated value of $\$ 274,000$ (production in tons not available) (U.S. Geological Survey, 2003a). Kelsey Lake diamond mine, Larimer County, Colo., was not mined during 2003. Its reserve is estimated at 18.7 million tons grading at 3.4 to 4.6 carats per 100 tons of kimberlite ore (Cappa and others, 2003).

\section{Diamonds}

Diamond-bearing kimberlite deposits are mined in open pits that are excavated by use of blasting, shovels, and bulldozers and underground with a method termed block caving. In Canada, some diamond mines are under water, so the kimberlite-bearing pipes are surrounded by dikes and then drained. Approximately 25 tons of rock are mined and processed to obtain 1 gram (5 metric carats) of diamonds (Reckling and others, 1994).

Alluvial mining can be as simple as a shovel and a pan that is filled with water and sediment and swirled to allow diamonds to settle to the bottom. Larger operations use equipment to move both ore and waste alluvium to a process plant, where the ore is crushed and screened, and scrubbers remove fine waste material. A heavy-medium separation further separates a diamond concentrate from the crushed ore. Diamonds and other high-density minerals sink to the bottom of cones whereas lighter minerals float to the top. Cyclones swirl the heavy minerals to the conical wall, while waste minerals are sucked up from the center of the vortex. Finally, x-ray fluorescence sorters or a vibrating grease table are used to extract diamonds from the residual waste. When exposed to $\mathrm{x}$ rays, diamonds fluoresce and thereby activate a jet of air that deflects the diamonds into a storage bin. The recovered diamonds are washed in acid or boiled in water and sorted.

\section{Minerals Sought by Collectors}

Old prospect pits and mine dumps may offer mineral specimens in weathered rock. For example, dumps at the Sedalia copper mine, north of Salida, Chaffee County, Colo., have produced large specimen-grade garnets (Pearl, 1972; Austin, 1995).

Collectors may dig shallow pits with simple hand tools, such as a shovel, pick, or hammer (fig. 57). Mineral specimens may be washed out of debris with a large hose and screened. Specimens are cleaned with water, chemical solutions, or mechanical methods (such as sharpened tools, ultrasound, and tumbling), trimmed, repaired, and preserved (Sinkankas, 1988). Gemstones may be irradiated, heat treated, or coated to enhance color.

\section{Fluorspar}

Fluorspar (the industrial name applied to the impure ores of fluorite) is a transparent to translucent mineral composed of calcium fluoride $\left(\mathrm{CaF}_{2}\right)$ (Eckel, 1997). Fluorspar is found in various colors (commonly blue or purple) and has a Mohs hardness of 4 (Bates and Jackson, 1987). The mineral has been used for centuries as a flux in various metallurgical processes; its name is derived from the Latin fluere, to flow (Encyclopedia Britannica, 2004a).

No domestic fluorspar was mined in 2003; all fluorspar was imported (Miller, 2004b). All domestic fluorspar is derived from sales of material from the U.S. Department of Defense National Defense Stockpile and from a small amount of synthetic fluorspar produced from industrial waste streams (Miller, 2004b).

Approximately 80 percent of fluorspar consumed in the United States is used to produce hydrofluoric acid and aluminum fluoride $\left(\mathrm{AlF}_{3}\right)$ (Miller, 2004b). Hydrofluoric acid is used in the manufacture of all fluorine-bearing chemicals. Fluorspar is also used to make iron and steel and in refrigerants, solvents, toothpaste, and anesthetics. Fluorosilicic acid $\left(\mathrm{H}_{2} \mathrm{SiF}_{6}\right)$, which is recovered from phosphoric acid plants that process phosphate rock, is used primarily in water fluoridation (Miller, 2004b). Legislation to reduce emissions of fluorinated gases in the European Union may reduce the demand for fluorspar and flurochemicals (Miller, 2004b).

\section{Geology of Colorado Fluorspar Deposits}

Most fluorspar deposits in central colorado are veins or replacements along faults and in fault breccia (rock along fault planes that was broken up during fault movement) that formed in tertiary time (fig. 58). Fluorspar is also a gangue mineral found in metalliferous veins in some mining districts in central colorado, where it is considered a waste mineral. The major fluorspar veins and replacement deposits (Jamestown, Northgate, and Browns Canyon districts) are all epithermal deposits formed by warm dilute aqueous solutions, probably of hot springs origin, moving through open faults and fault breccias at shallow depths. The temperatures at which these deposits 


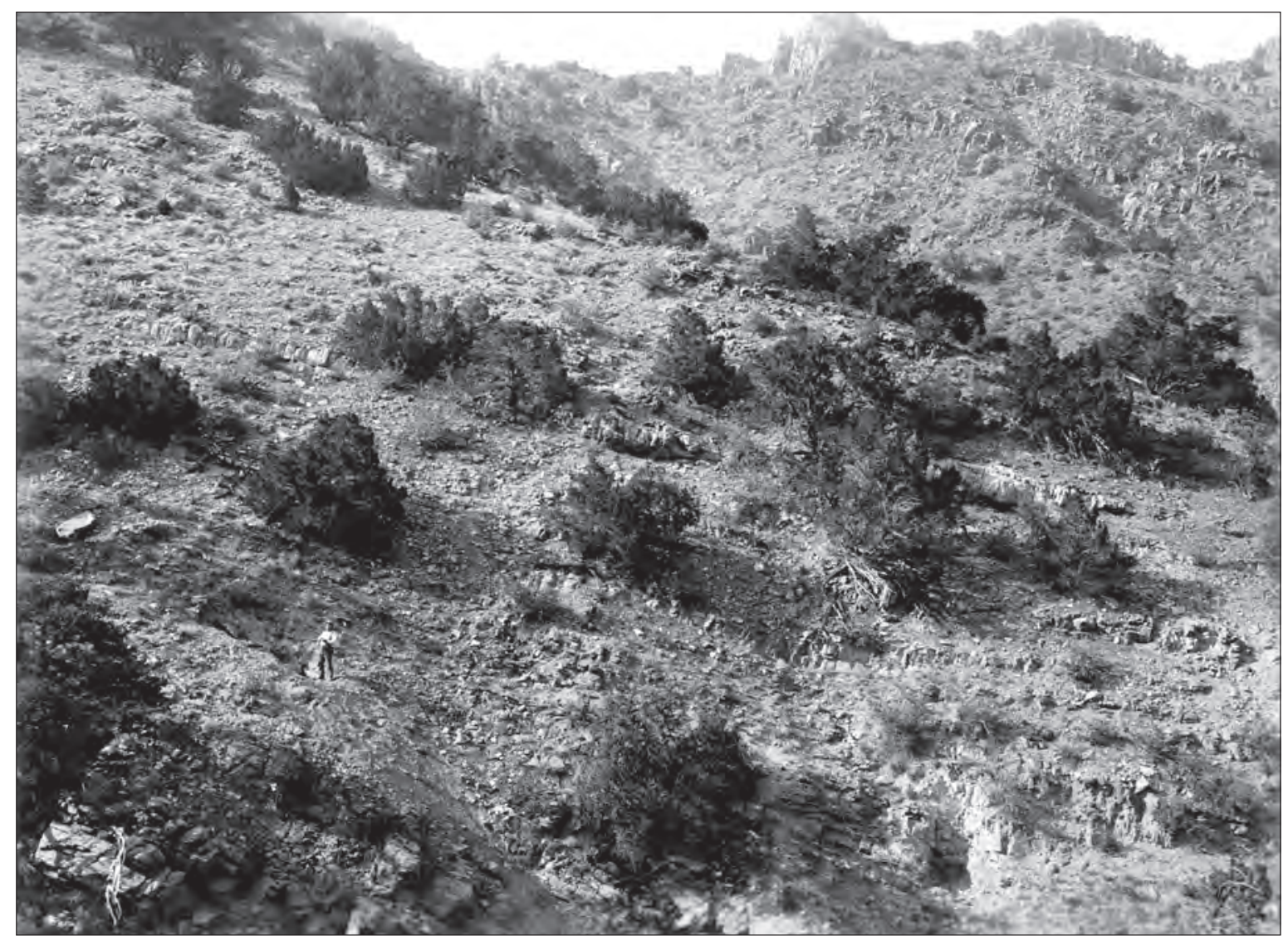

Figure 57. View looking north towards the Nelly E garnet mine, $2.5 \mathrm{mi}(4 \mathrm{~km})$ south of Cañon City, Colo., 1910. Most gems found in the pit where mine owner J.D. Endicott stands. Photograph by D.B. Sterrett. Courtesy of USGS Photographic Library.

formed were probably in the range of $50-200^{\circ} \mathrm{C}$ (Van Alstine, 1969). The deposits are characterized by fluorite and microcrystalline to chalcedonic quartz forming layered coatings on vein walls and around breccia fragments, as well as lining or filling vugs (small cavities in a vein or rock).

\section{Mining and Production}

Fluorspar veins may be mined in open pits with draglines, scrapers, or power shovels, or they may be extracted by underground mining techniques. Fluorspar is obtained by drilling and blasting the rock, followed by crushing and screening to remove waste. Additional beneficiation (such as concentration by gravity processes, froth flotation, and washing) may be needed to meet market specifications (Fulton and Montgomery, 1994).

Waste material is disposed of in tailing ponds or used as a cemented backfill in underground mining. "The disposal of mill tailings creates a problem because, even after impoundment and clarification, the liquid effluents may contain traces of chemicals that are in violation of environmental standards" (Fulton and Montgomery, 1994, p. 521).
Safe working conditions during mining of fluorspar require careful dust control (such as wet drilling, watering of loose rock, and general ventilation) (Stellman, 1998).

Fluorspar mining in Colorado ended in the 1970s (John Keller, Colorado Geological Survey, oral commun., 2006).

\section{Nahcolite}

Nahcolite is one of only a few minerals whose name also gives its chemical composition. The name nahcolite ( $\mathrm{NaHCO}_{3}$, naturally occurring sodium bicarbonate) is formed by changing the subscript 3 to the common mineral suffix “lite." Nahcolite is one source of soda ash $\left(\mathrm{Na}_{2} \mathrm{CO}_{3}\right.$, sodium carbonate); it can also be refined from the mineral trona $\left(\mathrm{Na}_{2} \mathrm{CO}_{3} \cdot \mathrm{NaHCO}_{3} \cdot 2 \mathrm{H}_{2} \mathrm{O}\right)$, brines of soda ash, or synthetic chemical processes (Kostick, 2004; Mineral Information Institute, 2004). Synthetic soda ash is the least desirable source; it is more costly to produce and generates environmentally deleterious wastes (Kostick, 2004).

Soda ash has applications in glass production, flue gas desulfurization, soaps and detergents, water treatment (by adjusting $\mathrm{pH}$ ), and pulp and paper production. Sodium 


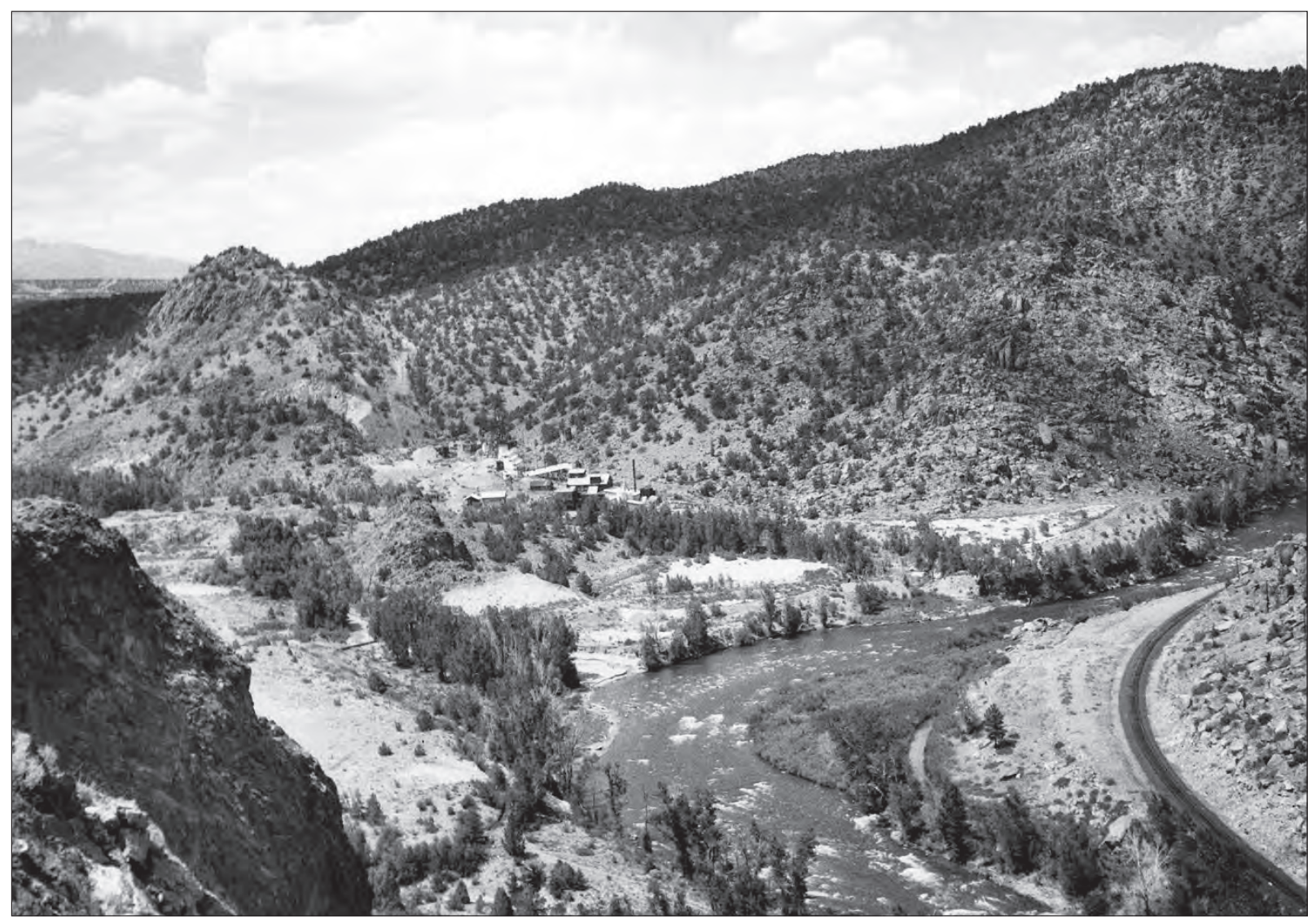

Figure 58. View northwest from Arkansas River, showing the main fault zone between hills of Tertiary rhyolite welded tuff (left) and Precambrian rocks (right) and the Colorado-American fluorspar mine, Chaffee County, Colo., about 1945. Photograph by R.E. Van Alstine. Courtesy of USGS Photographic Library.

bicarbonate (baking soda) is used in food products, animal feed, cleaning products, and pharmaceuticals.

The world's second-largest known soda ash resource is in the Piceance Basin, Rio Blanco County, northwest Colorado (Kostick, 1994; Eckel, 1997; Keller and Widmann, 2002), and the world's largest buried trona resource is in the Green River Basin of southwestern Wyoming (Mineral Information Institute, 2004).

\section{Geology of Colorado Nahcolite Deposits}

Nahcolite is an evaporite mineral that forms as inland lakes evaporate and concentrate sodium and carbonate ions. In Colorado, nahcolite is contained in the lacustrine sediments of the Parachute Creek Member of the Eocene Green River Formation (Keller and Widman, 2002). The Green River Formation contains sandstone, claystone, shale, dolomitic marlstone, oil shale, and thin beds of volcanic tuff deposited in Eocene Lake Uinta. Lake Uinta occupied the Uinta Basin in Utah and the Piceance Basin in northwestern Colorado. During especially arid times, evaporation caused the lake to become so saline that a large quantity of sodium salts, primarily nahcolite and halite, were precipitated from lake waters into pore spaces in sediments (Dyni, 1996).

\section{Mining and Production}

In Colorado, nahcolite ore is recovered from Eocene evaporite beds that lie about $610 \mathrm{~m}(2,000 \mathrm{ft})$ below the surface. Hot water injected through deep wells dissolves the nahcolite; nahcolite brine is then pumped to the surface and transported to a processing plant (fig. 59). If market conditions warrant, beds of nahcolite may also be developed in the future as a byproduct of shale oil production (Kostick, 1994).

Soda ash, sodium bicarbonate, and caustic soda $(\mathrm{NaOH}$, sodium hydroxide) are removed from evaporite beds by a variety of processes. In the case of soda ash, one process bubbles carbon dioxide gas into a saturated solution of sodium carbonate-bearing brines. The bicarbonate precipitates out and is then collected, filtered, and calcined to light soda ash (Kostick, 1994). Rotary bleaching units remove residual organic contaminants from the material; then the 


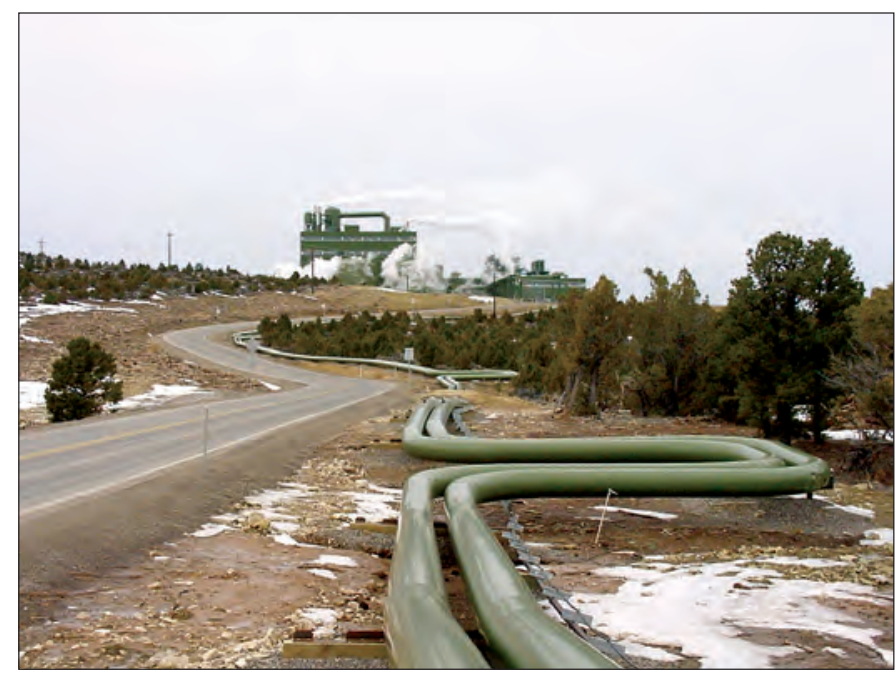

Figure 59. Nahcolite plant in Rio Blanco County, northwestern Colorado. Colorado is home to the only pure sodium bicarbonate deposits in the United States. Photograph by John Keller, Colorado Geological Survey.

light soda ash is concentrated, screened, dewatered, washed, and dried to yield dense soda ash. Clean recycled water can be piped from the processing plant to the mine site, where it is used again to dissolve more nahcolite. Producers may dredge additional sodium carbonate decahydrate crystals (a naturally occurring form of soda ash, $\mathrm{Na}_{2} \mathrm{CO}_{3} \cdot 10 \mathrm{H}_{2} \mathrm{O}$ ) from tailing ponds or directly inject the waste tailings underground (Kostick, 1994).

A possible adverse effect of extracting nahcolite is subsidence of the ground surface over mined areas.

In 2004, Colorado produced 79,400 tons of sodium bicarbonate from nahcolite in Rio Blanco County, less than in 2003 (Cappa and others, 2004). Additional sodium bicarbonate is produced in Rio Blanco County from trona brought by rail from Green River, Wyo. Although Colorado produced 550,000 tons of soda ash during 2003, production of soda ash ceased after spring, 2004 (Cappa and others, 2003; Cappa and others, 2004).

\section{Titanium}

Titanium ore was first discovered in 1791 in Cornish beach sands by an English clergyman and named after the giants of Greek mythology, the Titans (Encyclopedia Britannica, 2004b). The principal source of titanium is still sand deposits containing high-density minerals ("heavy minerals") such as zircon and the titanium minerals rutile (which is about 95 percent $\left.\mathrm{TiO}_{2}\right)$ or ilmenite $\left(\mathrm{FeTiO}_{3}\right)$.

Approximately 97 percent of titanium mineral concentrates are used as titanium dioxide $\left(\mathrm{TiO}_{2}\right)$, a pigment that is white and nonmetallic, rather than in a metallic form (Ti) (Keller and Widmann, 2002; Gambogi, 2005). Non-pigment uses of titanium ores are mostly in the production of titanium metal and titanium compounds. Because of its high strength, light weight, and resistance to corrosion, titanium is used in parts for aircraft, spacecraft, and ships; in joint prostheses as a replacement for bone and cartilage; as heat exchangers in desalination plants; and in other industrial processes (Christie and Brathwaite, 1998). On the basis of research on weathered ilmenite sands in the Murray Basin, Australia, ilmenite might be used to remove heavy metal and radioactive pollutants from mine drainage, industrial waste streams, and groundwater (Rive, 2004).

\section{Geology of Colorado Titanium Deposits}

Primary rutile is found in igneous and metamorphic rocks: alkalic igneous complexes (carbonatites), alkalic mafic complexes of norite or anorthosite, granitic to syenitic pegmatites, and high-grade, aluminum-rich metamorphic rocks. A third mineral, perovskite, is the primary titanium ore in an alkalic stock in the Powderhorn district, Gunnison County; ilmenite is present but less abundant. Primary ilmenite is associated with titaniferous iron ores of hematite or magnetite, often as magmatic segregations in alkalic and mafic intrusive rocks (Schwochow and Hornbaker, 1985). Sediments eroded from these rocks often contain large concentrations of heavy minerals, including rutile and ilmenite, which may form valuable secondary placer deposits.

The largest unmined titanium resource in the United States is the White Earth deposit in the Powderhorn district near Gunnison, Colo. (Colorado Mining Association, 2008). Titanium minerals (rutile and ilmenite), garnet, zircon, and some rare earth minerals are present within ancient beach placer deposits of minerals on the plains of eastern Colorado. These deposits occur in the Upper Cretaceous Fox Hills Sandstone and have been examined in recent years for their commercial potential.

\section{Mining and Production}

Ore from hard-rock deposits is crushed to a size that will liberate impurities, and then the titanium minerals are concentrated by magnetic separators or froth flotation (Christie and Brathwaite, 1998). Beneficiation is similar to that used for beach sands described below.

Heavy-mineral beach sands are extracted by suction dredges (DuPont, 2004). The sand slurry is discharged into a wet mill where it is screened and crushed, and the raw ore is roughly separated into valuable heavy mineral concentrates (including titanium minerals) and lighter minerals (such as quartz and feldspar) by gravity concentration methods (for example, gravity spirals or sluices). The tailings discharge is directed back into the pond as backfill. The heavy mineral concentrates often contain grains coated with organic material and clays; these impurities are removed through scrubbing with caustic soda ( $\mathrm{NaOH}$, sodium hydroxide). The concentrate is then dried and the titanium minerals are separated from other products by electrostatic separators. Next, the various titanium 
minerals are magnetically separated from each other. The magnetic fraction is collected and shipped as ilmenite; the nonmagnetic fraction is treated again to recover rutile and leucoxene (an alteration mineral of ilmenite). Zircon, a zirconium-bearing mineral, is a byproduct.

Titanium dioxide $\left(\mathrm{TiO}_{2}\right.$ ) can be produced by sulfate or chloride processes (Christie and Brathwaite, 1998). In the sulfate process, ilmenite ore is digested with sulfuric acid to remove iron, generating large quantities of waste iron sulfate. Alkali or oxygen is added to precipitate hydrous titanium dioxide, and the precipitate is heated to drive off water. The chloride process calcines a mixture of a mineral rutile (or synthetic rutile-ilmenite that has been processed to remove the iron component), a source of carbon (for example, coke), and chlorine to form "tickle" $\left(\mathrm{TiCl}_{4}\right.$, titanium tetrachloride). Tickle is condensed to a liquid from which impurities are removed as solids; it then is heated to a gas and mixed with oxygen, forming $\mathrm{TiO}_{2}$. Increasingly stringent environmental controls favor the chloride process because it creates fewer waste byproducts (Christie and Brathwaite, 1998, p. 8); the sulfate process generates large volumes of ferrous sulfate.

Mining beach sand for ilmenite generally presents few environmental hazards. However, some heavy-mineral sands have substantial quantities of the mineral monazite, which contains radioactive thorium (Australian Uranium Association, 2009). Monazite's radioactivity is low enough to not pose a health hazard unless the monazite itself is concentrated. Mitigating dust produced during processing of monazite sand reduces the potential hazard from inhaling thorium in dust form (Australian Uranium Association, 2009). However, disposal of wastes from pigment-producing processes that use ilmenite does cause concern (Garnar and Stanaway, 1994).

Titanium sponge (Ti), so called because of its appearance and high porosity, is the commercially pure, basic form of titanium metal. It is obtained by the Kroll process, in which rutile and rutile substitutes are treated with chlorine to form a volatile liquid ( $\mathrm{TiCl}_{4}$, titanium tetrachloride), and the liquid is reduced with liquid magnesium in an argon or helium atmosphere that yields the titanium sponge (Christie and Brathwaite, 1998). Nitric acid or hydrochloric acid is used to leach the sponge, whereas vacuum distillation separates the sponge. After drying, crushing, and screening, the sponge is processed into ingots or crushed to create titanium powder.

Titanium is not presently mined in Colorado (John Keller, Colorado Geological Survey, oral commun., 2006).

\section{Zeolite}

The word zeolite comes from the Greek zein, to boil, and lithos, stone, because the crystals bubble and froth when they are heated with a blowpipe (Holmes, 1994). Zeolites are associated with volcanic rocks and tuffaceous sedimentary rocks derived from volcanism. They are a group of natural or synthetic hydrated aluminosilicates of the alkaline and alkaline earth elements (Virta, 2003). Zeolites are sometimes called molecular sieves (fig. 60) because channels in their molecular structure allow them to absorb many cations or small molecules. Zeolites are used to remove harmful atmospheric and aqueous pollutants, as catalysts in many chemical processes (thus making reactions more energy efficient), in ion exchange (water softening and purification), and in reversible dehydration.

Zeolitic tuff has been used as a sculpturing stone and dimension stone for nearly 3,000 years (Christie and others, 2002). More than 70 percent of domestic natural zeolite is used for pet litter, animal feed, water purification, and horticultural applications (Virta, 2003). Zeolites are also used as a substitute for dimension stone, in lightweight aggregates, pozzolanic cement, and soil conditioners. Synthetic zeolites, which can be manufactured to a specific size of molecular channel, are used as catalysts, detergents, and molecular sieves (Virta, 2003). Environmental applications include treatment of water and sewage, adsorption and removal of pollutants, such as heavy metals, and purification of air and gas (Christie and others, 2002).

\section{Geology of Colorado Zeolite Deposits}

In basaltic to andesitic rocks, zeolites commonly occur as euhedral crystals filling open spaces. These crystals are sought by mineral collectors but have limited value as commercial industrial minerals. Volcanic rocks capping North and South Table Mountain near Golden, Colo., are widely known for museum-quality zeolite specimens. Commercial volumes of zeolites occur in bedded tuffs. These zeolites form by the reaction of pore water with

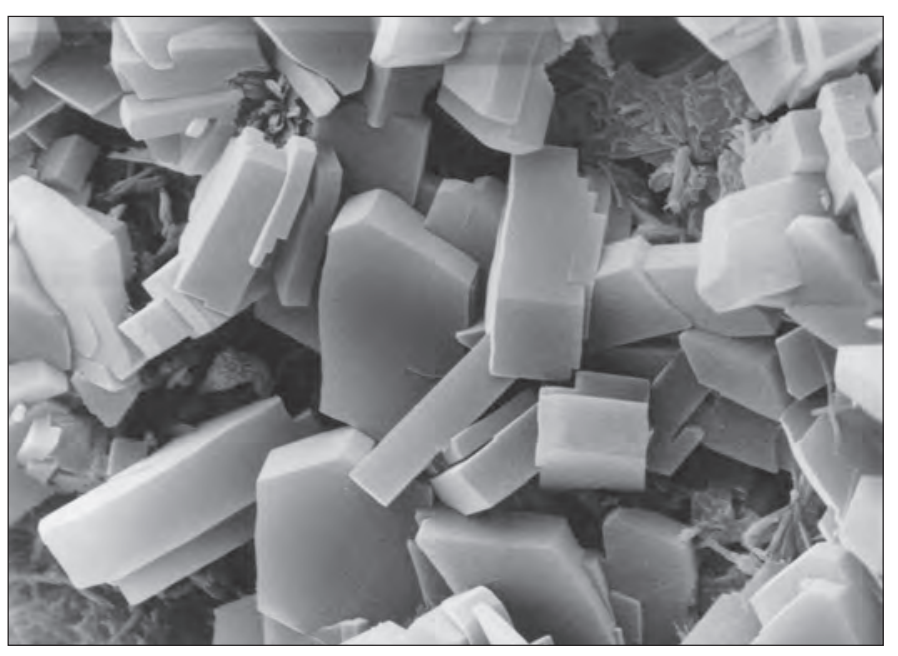

Figure 60. Euhedral crystals and intercrystal porosity in zeolite from a clinoptilolite-rich tuff, as seen in a scanning electron micrograph. Photograph courtesy of Richard Shepard. Euhedral is "said of a mineral grain that is completely bounded by its own rational faces, and whose growth during crystallization or recrystallization was not restrained or interfered with by adjacent grains" (Bates and Jackson, 1987, p. 224). 
volcanic glass, poorly crystalline clay minerals, plagioclase, and silica. The specific zeolite minerals that form depend on the composition of the tuffs and on their temperature, pressure, partial pressure of pore water, and $\mathrm{pH}$. With age, the first-formed zeolites are commonly replaced by different zeolite minerals such that older zeolite deposits are much less mineralogically diverse than younger ones (Harben and Kuzvart, 1997).

In Colorado, zeolites have been described in the oil shale and tuffaceous facies of the Green River Formation (Eocene), in tuffaceous mudstone in the Brushy Basin Member of the Morrison Formation (Jurassic), in a tuff in the Windy Gulch Member of the Bachelor Mountain Rhyolite (Oligocene), and in tuffaceous rocks of the Bridger Formation (Eocene) and Creede Formation (Oligocene) (Olson, 1983; Larsen and Crossey, 1995). Because a large volume of volcanic rocks erupted during the Tertiary in Colorado, other zeolite-bearing tuffs no doubt exist.

\section{Mining and Production}

Zeolite deposits are mined by conventional open pit mining methods and, if necessary, by blasting (fig. 61). Selective mining and blending may be used to produce high-value zeolites (Holmes, 1994). Excavated material is transported to a processing plant where it is crushed, screened, and milled for low-value products such as pet litter. The ore may be further processed by grinding and air separation to recover a particular particle size for industrial applications (Virta, 2003). In some cases, acid or salt washes are used to improve the quality of the zeolite.

Zeolite is not presently mined in Colorado (John Keller, Colorado Geological Survey, oral commun., 2006).

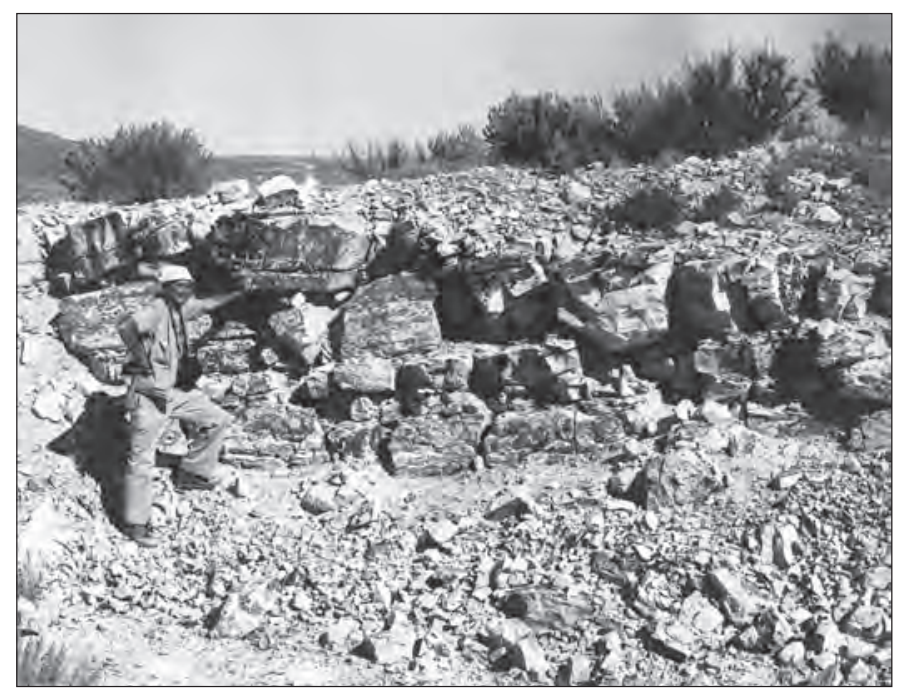

Figure 61. Small zeolite production pit in the Sucker Creek Formation, near Sheaville, Oregon, date unknown. Photograph by Richard Shepard.

\section{References Cited}

Adams, G.C., 1993, Gypsum and anhydrite in Nova Scotia: Nova Scotia Department of Natural Resources Information Circular ME16. Accessed December 29, 2004, at URL http://www.gov.ns.ca/natr/meb/pdf/ic16.asp

Agricola, Georgius, 1556, De re metallica: Accessed December 21, 2009 at URL http://www.mining-heritage.com

Alpers, C.N., Blowes., D.W., Nordstrom, D.K., and Jambor, J.L., 1994, Secondary minerals and acid mine-water chemistry, in Jambor, J.L., and Blowes, D.W., eds., Short course handbook on environmental geochemistry of sulfide mine-wastes: Waterloo, Ontario, Mineralogical Association of Canada, v. 22, p. 247-270.

Anderson, Bob, Berry, David, and Shields, Deborah, 2002, Sustainable development and its influence on mining operations on Federal lands-A conversation in plain language: Washington, D.C., U.S. Government Printing Office, Bureau of Land Management Information pamphlet BLMWO-GI-02-008+3000, 4 p.

Anglin, M.K., 2002, Women, power, and dissent in the hills of Carolina: Chicago, University of Illinois Press, 216 p.

Arbogast, Belinda, 2002, An overview of reclamation law dealing with mineral resource development in the USA, in Scott, P.W., and Bristow, C.M., eds., Industrial minerals and extractive industry geology: Geological Society [London], p. 283-293.

Arbogast, B.F., Knepper, D.H., Jr., and Langer, W.H., 2000, The human factor in mining reclamation: U.S. Geological Survey Circular 1191, 28 p.

Arkansas Geological Survey, 2009, Industrial minerals. Accessed December 21, 2009, at URL http://www.geology. ar.gov/minerals/industrial.htm

Armbrustmacher, T.J., 1988, Geology and resources of thorium and associated elements in the Wet Mountain area, Fremont and Custer Counties, Colorado: U.S. Geological Survey Professional Paper 1049-F, 34 p.

Arthur, L.M., Daniel, T.C., and Boster, R.S., 1977, Scenic assessment-An overview: Landscape Planning, v. 4, p. 109-129.

Austin, Gordon, 1995, An overview of production of specific U.S. gemstones: U.S. Bureau of Mines Special Publication 14-95, Washington, D.C., U.S. Government Printing Office, 41 p. Accessed June 22, 2005, at URL http://minerals. er.usgs.gov/minerals/pubs/commodity/gemstones/sp14-95/

Australian Uranium Association, 2009, Radiation control in the mining and mineral processing industry: Australian Uranium Association Radiation Workers' Handbook, 50 p. Accessed September 28, 2010, at URL http://www.aua.org. au/DisplayFile.Aspx?FileID=46 
Baldwin, Jonathan, Fisher, Peter, Wood, Joseph, and Langford, Mitchell, 1996, Modeling environmental cognition of the view with GIS, in International Conference and Workshop on Integrating GIS and Environmental Modeling, 3d, Santa Fe, New Mexico, National Center for Geographic Information and Analysis, CD-ROM.

Bancroft, Peter, 2000, UCSB geology-The Bancroft collection: Santa Barbara, University of California, Santa Barbara. Accessed September 3, 2010, at URL http://bancroft.geol.ucsb.edu/

Banks, K.M., 1999, Indians, reclamation, and historic preservation [abs.]: Plains Anthropologist, v. 44, no. 170, p. 5-12.

Barker, J.M., and Austin, G.S., 1994, Construction materialsDecorative stone, in Carr, D.D., ed., Industrial minerals and rocks (6th ed.): Littleton, Colorado, Society for Mining, Metallurgy, and Exploration, p. 367-378.

Bastian, C.T., McLeod, D.M., Germino, M.J., Reiners, W.A., and Blasko, B.J., 2002, Environmental amenities and agricultural land values-A hedonic model using geographic information systems data: Ecological Economics, v. 40, no. 3, p. 337-349.

Bates, R.L., 1969, Geology of the industrial rocks and minerals: New York, Dover Publications, 459 p.

Bates, R.L., and Jackson, J.A., 1987, Glossary of geology (3d ed.): Alexandria, Virginia, American Geological Institute, 788 p.

Belnap, Jayne, 2003, The world at your feet—Desert biological soil crusts: Frontiers in Ecology and the Environment, v. 1, no. 5, p. 181-189.

Bennett, J.W., 1993, Human ecology as human behavior: New Brunswick, New Jersey, Transaction Publishers, 357 p.

Berlin, George, 1964, Limestone for sugar refining, in Mineral and water resources of Colorado. Report of the United States Geological Survey in collaboration with the Colorado Mining Industrial Development Board: Washington, D.C., U.S. Government Printing Office, p. 202-203.

Bingham, Nancy, 2000, Mining's image-What does the public really think?: Mining Engineering, v. 46, no. 3, p. 200-203.

Bolen, W.P., 2004a, Sand and gravel (construction), in U.S. Geological Survey mineral commodity summaries 2004: Washington, D.C., U.S. Government Printing Office, p. 140-141.

Bolen, W.P., 2004b, Perlite, U.S. Geological Survey mineral commodity summaries 2004: Washington, D.C., U.S. Government Printing Office, p. 120-121.

Boulder County Land Use Department, 2008, 2d ed., Boulder County comprehensive plan "Goals, Policies, and Maps element": Land Use Department Publication, 137 p.

Breese, R.O.Y., and Barker, J.M., 1994, Perlite, in Carr, D.D., ed., Industrial minerals and rocks (6th ed.): Littleton, Colo., Society for Mining, Metallurgy, and Exploration, p. 735-749.
Brobst, D.A., 1994, Barium minerals, in Carr, D.D., ed., Industrial minerals and rocks (6th ed.): Littleton, Colo., Society for Mining, Metallurgy, and Exploration, Inc., p. 125-134.

Brown, W.H., 1989, When worlds collide-The gravel pit evaporation conflict: The Colorado Lawyer, Feb., p. 237-239.

Buchanan, B.J., ed., 2006, Gunpowder, explosives, and the state-A technological history: Burlington, Vermont, Ashgate Publishing Co., 425 p.

Bugosh, Nicholas, 2002, Slope and channel reclamation using fluvial geomorphic principles at San Juan Coal Company mines in New Mexico, [abs.], in Approaching bond release-Post-mining land use in the arid and semi-arid West: Bismarck, North Dakota, Office of Surface Mining, North Dakota State University, and North Dakota Public Service Commission, August 25-30, 2002, not paginated.

Bush, A.L., 1976, Vermiculite in the United States, in Proceedings of the Eleventh Forum on the Geology of Industrial Minerals, June 18-20, 1975, Kalispell, Montana: Montana Bureau of Mines and Geology Special Publication 74, p. 145-155.

Buttleman, C.G., 1992, A handbook for reclaiming sand and gravel pits in Minnesota: St. Paul, Minnesota Department of Natural Resources Division of Minerals, 65 p.

Buyhoff, G.J., Miller, P.A., Roach, J.W., Zhou, D., and Fuller, L.G., 1994, An A1 methodology for landscape visual assessment: A1 Applications, v. 8, no. 1, p. 1-13.

Cappa, J.A., Widmann, Beth, Carroll, C.J., Keller, J.S., and Young, Genevieve, 2003, Colorado mineral and mineral fuel activity 2003: Colorado Geological Survey Information Series 69, 56 p. Accessed September 8, 2010, at URL http:// www.geosurvey.state.co.us/pubs/mr/MMF-IS-69.pdf

Cappa, J.A., Young, Genevieve, Keller, J.W., Carroll, C.J., and Widmann, Beth, 2004, Colorado mineral and mineral fuel activity: Colorado Geological Survey Information Series 70, 45 p. Accessed September 8, 2010, at URL http://www. geosurvey.state.co.us/portals/0/MMF_2004_small.pdf

Carlson, Allen, 2001, On aesthetically appreciating human environments: Philosophy and Geography, v. 4, no. 1, p. 9-24.

Carr, D.D., Rooney, L.F., and Freas, R.C., 1994, Limestone and dolomite, in Carr, D.D., ed., Industrial minerals and rocks (6th ed.): Littleton, Colorado, Society for Mining, Metallurgy, and Exploration, p. 605-629.

Carter, D.A., 1964, Metallurgical limestone, in Mineral and water resources of Colorado-Report of the United States Geological Survey in collaboration with the Colorado Mining Industrial Development Board: Washington, D.C., U.S. Government Printing Office, p. 203-205. 
Carter, W.D., 1964, Sand and gravel, in Mineral and water resources of Colorado-Report of the United States Geological Survey in collaboration with the Colorado Mining Industrial Development Board: Washington, D.C., U.S. Government Printing Office, p. 205-211.

Chadwick, John, 2004, Supplying sustainability: Mining Environmental Manager, November, p. 2.

Christie, Tony, and Brathwaite, Bob, 1998, Mineral commodity report 16-Titanium: New Zealand Mining, v. 23, 11 p. Accessed August 11, 2010, at URL http:// www.crownminerals.govt.nz/cms/pdf-library/minerals/ minerals-overview-pdfs-1/report16_titanium.pdf/view

Christie, Tony, Brathwaite, Bob, and Thompson, Bruce, 2002, Mineral commodity report 23-Zeolites: New Zealand Mining, v. 31, p. 16-24. Accessed August 11, 2010, at URL http://www.crownminerals.govt.nz/cms/pdf-library/minerals/ minerals-overview-pdfs-1/report23-zeolite.pdf/view

Christie, Tony, Thompson, Bruce, and Brathwaite, Bob, 2001a, Mineral commodity report 22-Aggregate: New Zealand Mining, p. 6-26. Accessed August 11, 2010, at URL http://www.crownminerals.govt.nz/cms/pdf-library/ minerals/minerals-overview-pdfs-1/report22_aggregate.pdf

Christie, Tony, Thompson, Bruce, and Brathwaite, Bob, 2001b, Mineral commodity report 20-Clays: Ministry of Economic Development, 18 p. Accessed August 11, 2010, at URL http://www.crownminerals.govt.nz/ cms/pdf-library/minerals/minerals-overview-pdfs-1/ report20_clays.pdf/view

Colorado Department of Local Affairs Division of Local Government, 2010, Preliminary population forecasts by region, 2000-2035: State Demography Office. Accessed September 10, 2010, at URL http://dola.colorado.gov/dlg/demog/ pop_colo_forecasts.html

Colorado Department of Natural Resources Division of Minerals and Geology, 1998, In-stream aggregate extraction and reclamation guidance document: 46 p. and 6 appendixes.

Colorado Department of Natural Resources Division of Wildlife, 2003, Species conservation. Accessed September 10, 2010, at URL http://wildlife.state.co.us/WildlifeSpecies/ SpeciesOfConcern

Colorado Geological Survey, 1999, Colorado diamonds: Colorado Geological Survey RockTalk, v. 2, no. 3, 12 p.

Colorado Geological Survey, 2004a, Definitions and characteristics-Subsidence. Accessed September 10, 2010, at URL http://geosurvey.state.co.us/Default.aspx?tabid=358

Colorado Geological Survey, 2004b, Home page. Accessed September 10, 2010, at URL http://geosurvey.state.co.us
Colorado Historical Society Office of Archaeology and Historic Preservation, 2001, Colorado preservation 2005Enriching our future by preserving our past. Statewide historic preservation plan: Denver, Colorado Historical Society, 61 p. Accessed September 10, 2010, at URL http:// coloradohistroy-oahp.org/publications/pubs/1508.pdf

Colorado Historical Society Office of Archaeology and Historic Preservation, 2003, Directory of mining-related properties in the Colorado State register of historic properties (2d ed.): Denver, Colorado Historical Society, 28 p.

Colorado Mining Association, 2008, Mining-Colorado’s first industry: Accessed September 10, 2010, at URL http://www.coloradomining.org/Content/Body_Pdf/CMA_ Brochure_6-09_small.pdf

Colton, R.B., and Fitch, H.R., 1974, Map showing potential sources of gravel and crushed-rock aggregate in the Boulder-Fort Collins-Greeley area, Front Range urban corridor, Colorado: U.S. Geological Survey Miscellaneous Investigations Map I-855-D, scale 1:100,000.

Coopersmith, H.G., and Schulze, D.J., 1996, Development and geology of the Kelsey Lake diamond mine, Colorado, in Thompson, T.B., ed., Diamonds to gold: Society of Economic Geologists Guidebook 26, p. 5-19.

Courtney, Ann, 2001, Accelerated recovery-Bioremediation of the visual impact of limestone quarry scarps: Quarry Management, v. 28, no. 12, p. 47-48.

Daly, H.E., and Farley, Joshua, 2004, Ecological economics: Washington, D.C., Island Press, 454 p.

Daniel, T.C., and Vining, J., 1983, Methodological issues in the assessment of landscape quality, in Altman, I., and Wohwill, J., eds., Behavior and the natural environment: New York, Plenum Press, chap. 2, p. 39-83.

Daniels, Tom, 1999, When city and county collide-Managing growth in the metropolitan fringe: Washington, D.C., Island Press, 363 p.

Darmer, Gerhard, 1990, Landscape and surface miningEcological guidelines for reclamation. v. 1, Dietrich, N.L., ed., Berlin, Patzer Verlaz Gmblt U. Co., variously paged. [translated into English]

Denver Mineral Engineers, Inc., The basic processes of gold recovery: Sterling, Colo., Denver Mineral Engineers. Accessed September 10, 2010, at URL http://www. denvermineral.com/basicp 1.html

Dolley, T.P., 2004, Stone (dimension), in U.S. Geological Survey mineral commodity summaries 2004: Washington, D.C., U.S. Government Printing Office, p. 158-159.

Dorr, Ann, and Paty, A.H., 2002, Minerals-Foundations of society ( $3 \mathrm{~d}$ ed.): Alexandria, Virginia, American Geological Institute, $96 \mathrm{p}$. 
Dumont, Michel, 2004, Clays: Natural Resources Canada Mineral and Metal Commodity Reviews, Ottawa, Ontario, Natural Resources Canada, 13 p. Accessed September 11, 2010, at URL http://www.nrcan.gc.ca/mms-smm/busi-indu/ cmy-amc/content/2004/clays.pdf

DuPont, 2004, DuPont titanium technologies. Accessed September 10, 2010, at URL http://www.titanium.dupont.com/ NASApp/TTPORTAL/Meidator?action=261\&reference

Dyni, J.R., 1996, Sodium carbonate resources of the Green River Formation: U.S. Geological Survey Open-File Report OFR 96-729, 39 p.

Eckel, E.B., 1961, Minerals of Colorado-A 100-year record: U.S. Geological Survey Bulletin 1114, 399 p.

Eckel, E.B., 1997, Minerals of Colorado (4th ed.): Golden, Colorado, Fulcrum Publishing, 665 p.

Elzea, Jessica, and Murray, H.H., 1994, Bentonite, in Carr, D.D., ed., Industrial minerals and rocks (6th ed.): Littleton, Colorado, Society for Mining, Metallurgy, and Exploration, p. 233-246.

Encyclopedia Britannica, 2004a, Fluorspar, in Encyclopedia Britannica Premium Service. Accessed September 10, 2010, at URL http://www.britannica.com

Encyclopedia Britannica, 2004b, Titanium, Encyclopedia Britannica Premium Service. Accessed September 10, 2010, at URL http://www.britannica.com

English Nature, Quarry Products Association, and Silica and Moulding Sands Association, 1999, Biodiversity and minerals - Extracting the benefits for wildlife: Newcastle upon Tyne, United Kingdom, Entec UK Ltd., 13 p.

Environment Australia, 2002, Overview of best practice environmental management in mining. Accessed September 13, 2010, at URL http://www.ret.gov.au/resources/Documents/ LPSDP/BPEMOverview.pdf

Environmental Mining Council of British Columbia, 2004, A mineral-efficient future. Accessed September 13, 2010, at URL http://www.miningwatch.ca/en/mineral-efficient-future

Foley, Nora, 1999, Environmental characteristics of clays and clay mineral deposits. Accessed September 13, 2010, at URL http://pubs.usgs.gov/info/clays/

Fong, Tillie, 2005, Aurora OKs water-storage deal: Rocky Mountain News, March 22, p. 6A

Fulton, R.B., and Montgomery, Gill, 1994, Fluorspar, in Carr, D.D., Industrial minerals and rocks (6th ed.): Littleton, Colorado, Society for Mining, Metallurgy, and Exploration, p. 509-522.

Gambogi, Joseph, 2005, Titanium and titanium dioxide, p. 178-179. Accessed September 13, 2010, at URL http:// minerals.usgs.gov/minerals/pubs/commodity/titanium/ tidiomcs05.pdf
Garnar, T.E., and Stanaway, K.J., 1994, Titanium minerals, in Carr, D.D., ed., Industrial minerals and rocks (6th ed.): Littleton, Colorado, Society for Mining, Metallurgy, and Exploration, p. 1071-1089.

Goldman, H.B., 1994, Sand and gravel, in Carr, D.D., ed., Industrial minerals and rocks (6th ed.): Littleton, Colorado, Society for Mining, Metallurgy, and Exploration, Inc., p. 869-877.

Gratzfeld, Joachim, ed., 2003, Extractive industries in arid and semi-arid zones: Gland, Switzerland, The World Conservation Union, 111 p.

Hammarstrom, J.M., and Smith, K.S., 2002, Geochemical and mineralogic characterization of solids and their effects on waters in metal-mining environments, in Seal II, R.R., and Foley, N.K., eds., Progress on geoenviromental models for selected mineral deposits types: U.S. Geological Survey Open-File Report 02-195, Online version 1.0, Chapter B, 47 p. Accessed January 19, 2005, at URL http://pubs.usgs. gov/of/2002/of02-195

Harben, P.W., and Kuzvart, Milos, 1997, Zeolite, in Industrial minerals-A global geology: Worcester Park, Surrey, U.K., Industrial Minerals Information, Ltd., p. 445-450.

Hedrick, J.B., 2004, Mica, in U.S. Geological Survey mineral commodity summaries 2004: Washington, D.C., U.S. Government Printing Office, p. 108-111.

Herrick, D.H., 1994, Stone, crushed, in Carr, D.D. Industrial minerals and rocks (6th ed.): Littleton, Colorado, Society for Mining, Metallurgy, and Exploration, p. 975-986.

Hindman, J.R., 1994, Vermiculite, in Carr, D.D., Industrial minerals and rocks (6th ed.): Littleton, Colorado, Society for Mining, Metallurgy, and Exploration, p. 1103-1111.

Holmes, D.A., 1994, Zeolites, in Carr, D.D., Industrial minerals and rocks (6th ed.): Littleton, Colorado, Society for Mining, Metallurgy, and Exploration, p. 1129-1158.

Hosterman, J.W., and Orris, G.J., 1998a, Preliminary descriptive model of hydrothermal bentonite, in Orris, G.J., ed., Additional descriptive models of industrial mineral deposits: U.S. Geological Survey Open-File Report 98-505, p. 18-20.

Hosterman, J.W., and Orris, G.J., 1998b, Preliminary descriptive model of hydrothermal kaolin, in Orris, G.J., ed., Additional descriptive models of industrial mineral deposits: U.S. Geological Survey Open-File Report 98-505, p. 21-23.

Industrial Minerals Association North America, 2004, About industrial minerals. Accessed October 26, 2004, at URL http://www.ima-na.org/

Jefferson County, Colorado Planning and Zoning, 1977, Mineral extraction policy plan, 44 p. Accessed September 13, 2010, at URL http://www.co.jefferson.co.us/jeffco/planning_ uploads/plans/mineral_extraction_policy.pdf 
Jellicoe, Geoffrey, and Jellicoe, Susan, 1987, The landscape of man-Shaping the environment from prehistory to the present day: London, Thames and Hudson Ltd., $400 \mathrm{p}$.

Kasprzak, Rick, 2000, Artificial reef program: Louisiana Department of Wildlife and Fisheries. Accessed September 16, 2010, at URL http://www.wlf.louisiana.gov/fishing/ programs/habitat/artificialreef.cfm

Keller, J.W., and Widmann, B.L., 2002, Industrial mineralsWhat are they, where are they, and what good are they?: Colorado Geological Survey RockTalk, v. 5, no. 3, 12 p. Accessed September 16, 2010, at URL http://geosurvey. state.co.us/pubs/rocktalk/rtv5n3.pdf

Kellert, S.R., and Wilson, E.O., eds., 1993, The biophilia hypothesis: Washington, D.C., Island Press, 484 p.

Ketner, K.B., 1973, Silica sand, in Brobst, D.A., and Pratt, W.P., eds., United States mineral resources: U.S. Geological Survey Professional Paper 820, p. 577-580.

King, T.V.V., ed., 1995, Environmental considerations of active and abandoned mine lands - Lessons learned from Summitville, Colorado: U.S. Geological Survey Bulletin 2220, 38 p.

Knepper, D.H., Jr., ed., 2002, Planning for the conservation and development of infrastructure resources in urban areas-Colorado Front Range urban corridor: U.S. Geological Survey Circular 1219, 27 p.

Kostick, D.S., 1994, Soda ash, in Carr, D.D., ed., Industrial minerals and rocks (6th ed.): Littleton, Colorado, Society for Mining, Metallurgy, and Exploration, p. 929-958.

Kostick, D.S., 2004, Soda ash, in Mineral commodity summaries 2004: Washington, D.C., U.S. Government Printing Office, U.S. Geological Survey, p. 152. Accessed September 16, 2010, at URL http://minerals.usgs.gov/minerals/pubs/ commodity/soda_ash/

Krönert, Rudolf, Volk, Martin, and Steinhardt, Uta, 2001, Introduction-Landscape balance and landscape assessment, in Krönert, Rudolf, Steinhardt, Uta, and Volk, Martin, eds., Landscape balance and landscape assessment: Berlin, Springer, p. 1-22.

Kuzvart, Milos, 2003, Industrial minerals support economic geology in a globalized world: Society for Geology Applied to Mineral Deposits, 13 p. Accessed September 16, 2010, at URL http://www.e-sga.org/fileadmin/sga/ newsletter/news12/art1.html

Landscape Institute and Institute of Environmental Management and Assessment, 2002, Guidelines for landscape and visual impact assessment (2d ed.): London, Spon Press, 166 p.
Lafarge North America, 2005, Reclaiming land and ancestry. Accessed November 18, 2010, at URL http:// www.lafargenorthamerica.com/wps/portal/!ut/p/ kcxml/04_Sj9SPykssy0xPLMnMzOvMOY_QjzKLN4 r3MgXJgFjGQBayiEG8I1zA1yM_N1U_SN9bP0C_ IDc0otzRUREAM6pfXA!!/delta/base64xml/L3d JdyEvd0ZNQUFzQUMvNEIVRS82XzJfUOM!? WCM_GLOBAL_CONTEXT=/wps/wcm/connect/LNA/ Library/Case+Studies/Environment/Case_Study_ Lafarge + Land + Donation

Langer, W.H., and Glanzman, V.M., 1993, Natural aggregate-Building America's future: U.S. Geological Survey Circular 1110, 39 p.

Larsen, Daniel, and Crossey, L.J., 1995, Depositional environments and authigenic mineral distributions in the Oligocene Creede Formation, Colorado, USA, in Bethke, P.M., ed., Preliminary scientific results of the Creede caldera continental scientific drilling program: U.S. Geological Survey Open-File Report 94-260E, 76p.

Lin, Hui, Gong, Jianhua, Tsou, Jinyeu, Zhao, Yibin, Zhang, Zongyu, and Zhan, F.B., 2002, VGE-A new communication platform for general public, in International Conference on Web Information Systems Engineering, 3d, Singapore. Accessed September 16, 2010, at URL http://www.computer.org/portal/web/csdl/doi/10.1109/ WISEW.2002.1177846

Lindsey, D.A., Langer, W.H., and Knepper, D.H., Jr., 2005, Stratigraphy, lithology, and sedimentary features of Quaternary alluvial deposits of the South Platte River and some of its tributaries east of the Front Range: U.S. Geological Survey Professional Paper 1705, 70 p.

Lindvall, R.M., 1964, Stone, in Mineral and water resources of Colorado: Report of the United States Geological Survey in collaboration with the Colorado Mining Industrial Development Board: Washington, D.C., U.S. Government Printing Office, p. 211-215.

Lovering, T.S., and Goddard, E.N., 1950, Geology and ore deposits of the Front Range, Colorado: U.S. Geological Survey Professional Paper 223, 319 p.

Lovering, T.S., and Mallory, W.W., 1962, The Eagle Valley Evaporite and its relation to the Minturn and Maroon Formations, northwest Colorado: U.S. Geological Survey Professional Paper 450-D, p. D45-D48.

Macaulay Land Use Research Institute, 2005, Review of existing methods of landscape assessment and evaluation. Accessed September 16, 2010, at URL http://www. macaulay.ac.uk/ccw/task-two/evaluate.html

Magill, A.W., 1992, Managed and natural landscape-What do people like?: Albany, Calif., Pacific Southwest Research Station, 28 p. 
Makhzoumi, J.M., 2002, Landscape in the Middle East-An inquiry: Landscape Research, v. 27, no. 3, p. 213-228.

Mallory, W.W., 1971, The Eagle Valley Evaporite, northwest Colorado-A regional synthesis: U.S. Geological Survey Bulletin 1311-E, 37 p.

McCarl, H.N., 1994, Aggregates-Markets and uses, in Carr, D.D., ed., Industrial minerals and rocks (6th ed.): Littleton, Colorado, Society for Mining, Metallurgy, and Exploration, Inc., p. 286-294.

Meitner, M.J., and Daniel, T.C., 1997, Vista scenic beauty estimation modeling - A GIS approach, in ESRI International User Conference, San Diego, July 1997, Proceedings. Accessed September 17, 2010, at URL http://training. esri.com/campus/library/Bibliography/RecordDetail. $c f m ? I D=4631$

Meredith, T.C., 2004, Community participation in environmental information management-Exploring tools for developing an impact assessment preparedness program: Canadian Environmental Assessment Agency Research and Development Monograph Series 2000, Catalog no. En105-3/812004E. Accessed September 17, 2010, at URL http://www. ceaa-acee.gc.ca/default.asp?lang $=$ En\&n=5EC2AF64-1

Merriam-Webster, 2009, Merriam-Webster OnLine. Accessed September 17, 2010, at URL http://www.merriam-webster. com/dictionary

Miller, M.M., 2001, Fluorspar, 11 p. Accessed September 17, 2010, at URL http://minerals.usgs.gov/minerals/pubs/ commodity/fluorspar/280401.pdf

Miller, M.M., 2004a, Lime, in U.S. Geological Survey mineral commodity summaries 2004: Washington, D.C., U.S. Government Printing Office, p. 96-97.

Miller, M.M., 2004b, Fluorspar, in U.S. Geological Survey Mineral commodity summaries 2004: Washington, D.C., U.S. Government Printing Office, p. 62-63.

Mineral Information Institute, 2004, Everything we have and everything we use comes from our natural resources. Accessed September 17, 2010, at URL http://www.mii.org

Moss, Elaine, ed., 1977, Land use control in the United States_A handbook on the legal rights of citizens (National Resources Defense Council): New York, Dial Press, 362 p.

Murphy, J.A., 1995, Geology tour of Denver's buildings and monuments: Denver, Historic Denver, Inc., 96 p.

Murphy, J.A., and Modreski, P.J., 2002, A tour of Colorado gemstone localities: Rocks \& Minerals, v. 77, no. 4, p. 218-238.

National Academy of Sciences, 1974, Rehabilitation potential of western coal lands: Cambridge, Mass., Ballinger Publishing Co., 198 p.
National Academy of Sciences, 1999, Hardrock mining on Federal lands: Washington, D.C., National Academy Press, 260 p. Accessed September 17, 2010, at URL http://www. nap.edu/catalog.php?record_id=9682

National Industrial Sand Association, 1997, Crystalline silica respiratory health effects. Accessed September 17, 2010, at URL http://www.riccisand.com/pages/health1.html

National Stone Association, 1995, Environmental management guide: Washington, D.C., National Stone Association, variously paged.

Nichols, J.C., 1999, Minerals and geology: U.S. Department of Agriculture Forest Service. Accessed September 17, 2010, at URL http://www.fs.fed.us/r8/ouachita/naturalresources/minerals/index.shtml

Noel, T.J., Mahoney, P.F., and Stevens, R.E., 1994, Historical atlas of Colorado: Norman, University of Oklahoma Press, variously paged.

Norman, D.K., and Lingley, W.S., Jr., 1992, Reclamation of sand and gravel pits: Washington Geology, v. 20, no. 3, p. 20-31.

Norman, D.K., Wampler, P.J., Throop, A.H., Schnitzer, E.F., and Roloff, J.M., 1997, Best management practices for reclaiming surface mines in Washington and Oregon: Washington Department of Natural Resources Division of Geology and Earth Sciences Open File Report 96-2, 128 p.

Northrop, H.R., and Whitney, Gene, 1987, Clays and associated minerals in the Alum Mountain fossil geothermal system near Gila Hot Springs, Grant County, New Mexico, in Mumpton, F.A., ed., Zeo-Trip '87-An excursion to selected zeolite and clay deposits in southwestern New Mexico and eastern Arizona: Brockport, New York, International Committee on Natural Zeolites, p. 1-12.

Ober, J.A., 2002, Materials flow of sulfur: U.S. Geological Survey Open-File Report 02-298, version 1.0, 56 p. Accessed September 20, 2010, at URL http://pubs.usgs.gov/ of/2002/of02-298/of02-298.pdf

Ober, J.A., 2004, Sulfur, in U.S. Geological Survey mineral commodity summaries 2004: Washington, D.C., U.S. Government Printing Office, p. 162-163.

Olsen, J.C., Marvin, R.F., Parker, R.L., and Mehnert, H.H., 1977, Age and tectonic setting of lower Paleozoic alkalic and mafic rocks, carbonatites, and thorium veins in south-central Colorado: U.S. Geological Survey Journal of Research, v. 5, no. 6, p. 673-687.

Olson, D.W., 2004a, Gypsum, in U.S. Geological Survey mineral commodity summaries 2004: Washington, D.C., U.S. Government Printing Office, p. 76-77.

Olson, D.W., 2004b, Diamond (industrial), in U.S. Geological Survey mineral commodity summaries 2004: Washington, D.C., U.S. Government Printing Office, p. 56-57. 
Olson, R.H., 1983, Zeolites, in Lefond, S.J., ed., Industrial minerals and rocks (5th ed.): New York, Society of Mining Engineers, v. 2, p. 1391-1399.

Organization for Economic Co-operation and Development, 2001, Significant environmental achievements in the 1990s, says OECD: Science of the Total Environment, v. 278, p. 265-266.

Panagapko, Doug, 2003, Stone, in Canadian minerals yearbook: Ottowa, Ontario, Natural Resources Canada, 17 p. Accessed September 20, 2010, at URL http://www.nrcan-rncan.gc.ca/ mms-smm/busi-indu/cmy-amc/content/2003/56.pdf

Patterson, S.H., 1964, Clays, in Mineral and water resources of Colorado-Report of the United States Geological Survey in collaboration with the Colorado Mining Industrial Development Board: Washington, D.C., U.S. Government Printing Office, p. 183-190.

Pavement Interactive, 2008, Superpave mix design: Accessed September 10, 2010, at URL http://pavementinteractive.org/ index/php?tot;e=Superpave_Mix_Design

Pearl, R.M., 1972, Colorado gem trails and mineral guide (3d ed.): Athens, Ohio, Ohio University Press and Swallow Press, 222 p.

Perry, Edward, 2004, EMS for integrated business risk management: Mining Engineering Management, November, p. 17-19.

Peters, W.C., 1978, Exploration and mining geology (2d ed.): New York, John Wiley, 685 p.

Petts, G.E., and Amoros, C., eds., 1996, Fluvial hydrosystems: London, Chapman and Hall, $322 \mathrm{p}$.

Pickering, S.M., Jr., and Murray, H.H., 1994, Kaolin, in Carr, D.D., ed., Industrial minerals and rocks (6th ed.): Littleton, Colorado, Society for Mining, Metallurgy, and Exploration, p. 255-278.

Porteous, J.D., 1996, Environmental aesthetics-Ideas, politics and planning: London, Routledge, $290 \mathrm{p}$.

Potter, M.J., 2005, Feldspar, in U.S. Geological Survey mineral commodity summaries 2005: Washington, D.C., U.S. Government Printing Office, p. 60-61.

Power, W.R., 1994, Stone, dimension, in Carr, D.D., ed., Industrial minerals and rocks (6th ed.): Littleton, Colorado, Society for Mining, Metallurgy, and Exploration, p. 987-1001.

Prasciunas, M.M., 2003, Archeological testing at the Black Dumps site, Chaffee County, Colorado: University of Wyoming George C. Frison Institute of Archaeology and Anthropology Bulletin, p. 6. Accessed September 20, 2010, at URL http://www.uwyo.edu/frisoninstsupport/docs/ bulletins/BLTN\%2010.pdf
Pring, G.W., 2003, International law and mineral resources, in Mining, environment and development-A series of papers prepared for the United Nations Conference on Trade and Development (UNCTAD): New York, UNCTAD, 55 p. Accessed September 20, 2010, at URL http://www.adbi.org/3rdpartycd rom/2003/12/01/772.mining.environment.and.development/

Raabe, Steve, 2002, Trapper mine reclamation attracts wildlife, wins praise: Colorado Mining Association, November 12, 2002. Accessed September 8, 2010, at URL http://www. coloradomining.org/releasedetail.php?R_ID $=102$

Reckling, K., Hoy, R.B., Lefond, S.J., Fullerton, D.G., and Rowell, U.H., 1994, Diamonds, industrial, in Carr, D.D., ed., Industrial minerals and rocks (6th ed.): Littleton, Colorado, Society for Mining, Metallurgy, and Exploration, p. 379-395.

Rive, Meg, 2004, Ilmenite sieves could capture toxic wastes: Process Magazine. Accessed September 20, 2010, at URL http://www.csiro.au/resources/ProcessJune04.html

Robertson, Andy, and Shaw, Shannon, 2004, Use of the multiple accounts analysis process for sustainability optimization, in Society for Mining and Engineering Annual Meeting, February 23-25, 2004, Denver, Proceedings, 8 p. Accessed September 20, 2010, at URL http:// www.robertsongeoconsultants.com/publications/MAA_ SME_2004.pdf

Schumann, Walter, 2007, 3d ed., Gemstones of the world: New York, Sterling Publishing Co., Inc., 324 p.

Schwochow, S.D., and Hornbaker, A.L., 1985, Geology and resource potential of strategic minerals in Colorado: Denver, Colorado Geological Survey, Information Series 17, 70 p.

Scott, Alister, 2002, Assessing public perception of landscape-The LANDMAP experience: Landscape Research, v. 27, no. 3, p. 271-295.

Scott, G.R., 1964, Gem stones, in Mineral and water resources of Colorado: U.S. Geological Survey and Colorado Minerals Industrial Development Board, 90th Congress, 2d session, p. 165-168.

Searls, J.P., 2003, Barite, in U.S. Geological Survey minerals yearbook-2003: U.S. Geological Survey, 11 p. Accessed September 20, 2910, at URL http://minerals.usgs.gov/ minerals/pubs/commodity/barite/080303.pdf

Searls, J.P., 2004, Barite, in U.S. Geological Survey mineral commodity summaries 2004: Washington, D.C., U.S. Government Printing Office, p. 28-29.

Shaw, S.C., Roberts, A. MacG., Maehl, W.C., Kuipers, J., and Haigt, S., 2001, Review of the multiple accounts analysis alternatives evaluation process completed for the reclamation of the Zortman and Landusky mine sites, in National Association of Abandoned Mine Lands Annual Conference, August 19-22, 2001, Athens, Ohio, Proceedings, 17 p. 
Simmons, W.B., Jr., and Heinrich, E.W., 1980, Rare-earth pegmatites of the South Platte district, Colorado: Colorado Geological Survey Resource Series 11, 131 p.

Sinkankas, John, 1988, Field collecting gemstones and minerals (formerly titled Gemstones and minerals-How and where to find them): Prescott, Arizona, Geoscience Press, 397 p.

Society for Ecological Restoration, 2004, The SER international primer on ecological restoration. Accessed September 20, 2010, at URL http://www.ser.org/content/ecological_ restoration_primer.asp

Steinhardt, Uta, and Volk, Martin, 2001, Scales and spatial-temporal dimensions in landscape research, in Krönert, Rudolf, Steinhardt, Uta, and Volk, Martin, eds., Landscape balance and landscape assessment: Berlin, Springer, p. 137-162.

Stellman, J.M., 1998, Minerals (adapted from 3d ed.), in Bruusgaard, A., Cash, Jr., L.L., Donatello, G., D’Onofrio, V., Faraone, G., Kleinfeld, M., Landwehr, M., Meiklejohn, A., Pendergrass, J.A., Roach, S.A., Roscina, T.A., Sadkovskaja, N.I., and Stahl, R., Encyclopedia of occupation health and safety (4th ed.): International Labour Office Canadian Centre for Occupational Health and Safety. Accessed September 23, 2010, at URL http://www.ilo.org/ safework_bookshelf/english?content\&nd=857170713

Stone, Tammy, 1999, The prehistory of Colorado and adjacent areas: Salt Lake City, University of Utah Press, 214 p.

Streufert, R.K., Kirkham, R.M., Widmann, B.L., and Schroeder, T.J., II, 1997, Geologic map of the Cottonwood Pass quadrangle, Eagle and Garfield Counties, Colorado: Colorado Geological Survey Open-file Report 97-5. Accessed September 23, 2010, at URL http://geosurvey. state.co.us/Default.aspx?mid=904

Tapsell, S.M., 1995, River restoration-What are we restoring to?-A case study of the Ravensbourne River, London: Landscape Research, v. 20, no. 3, p. 98-111.

Tepordei, V.V., 1999, Natural aggregates-Foundation of America's future: U.S. Geological Survey Fact Sheet FS 144-97, 4 p. Accessed September 23. 2010, at URL http:// minerals.usgs.gov/minerals/pubs/commodity/aggregates/ fs14497.pdf

Tepordei, V.V., 2004, Stone, crushed, in U.S. Geological Survey 2004 minerals yearbook. Accessed September 29, 2010, at URL http://minerals.usgs.gov/minerals/pubs/commodity/ stone_crushed/cstonmyb04.pdf

Thompson, T.B., 1996, State Line kimberlite field trip-Kelsey Lake mine, in Thompson, T.B., ed., Diamonds to gold: Society of Economic Geologists Guidebook 26, p. 1-4.

Toy, T.J., and Hadley, R.E., 1987, Geomorphology and reclamation of disturbed lands: Orlando, Florida, Academic Press, 480 p.
Trimble, K.D., 1997, Scientific soundness and socio-economic realities in reclamation for habitat, in Brandt, J.E. and others, eds., Annual National Meeting of American Society for Surface Mining and Reclamation, 14th, Austin, Texas, Proceedings: p. 317-324.

Tweto, Ogden, 1987, Rock units of the Precambrian basement in Colorado: U.S. Geological Survey Professional Paper 1321-A, 54 p.

Ulrich, R.S., 1977, Visual landscape preference-A model and application: Man-Environment Systems, v. 7, no. 5, p. 279-293.

United Nations, 1992, Statement of forest principles, in Report of the United Nations Conference on Environment and Development, Rio de Janeiro, 3-14 June, 1992, A/ CONF.151/26, v. III. Accessed September 29, 2010, at URL http://www.un.org/documents/ga/conf151/aconf151263annex3.htm

United Nations, 2003a, Mining, environment and development-Documents of mining and sustainable development from United Nations and other organizations. Accessed September 23, 2010, at URL http://www.adbi.org/3rdpartycd rom/2003/12/01/772.mining.environment.and.development/

United Nations, 2003b, Agenda 21, Chap. 4. Changing consumption patterns: New York, U.N. Department of Economic and Social Affairs Division for Sustainable Development. Accessed September 23, 2010, at URL http://www. un.org/esa/dsd/agenda21/res_agenda21_04.shtml

U.S. Bureau of Land Management, 1964, Regulations pertaining to mining claims under the General Mining Laws of 1872, multiple use, and special disposal provisions: U.S. Department of the Interior Circular 2149, 45 p.

U.S. Bureau of Land Management, 1984, Visual resource management-BLM manual handbook H-8400, Rel. 8-24: Washington, D.C., U.S. Government Printing Office, approx. 24 p.

U.S. Bureau of Land Management, 1986a, Visual resource inventory-BLM manual handbook 8410-1: Washington, D.C., U.S. Government Printing Office, variously paged.

U.S. Bureau of Land Management, 1986b, Visual resource contrast rating-BLM Manual Handbook 8431-1: Washington, D.C., U.S. Government Printing Office, variously paged.

U.S. Bureau of Land Management, 1994, Data element dictionary: Denver, U.S. Bureau of Land Management, p. 204-233.

U.S. Bureau of Land Management, 1996, Mining claims and sites on Federal lands: Information pamphlet BLM-WOGI-91-002-4130, Washington, D.C., U.S. Government Printing Office, 27 p. 
U.S. Bureau of Land Management, 1997, Public lands statistics 1997. Part 1. Land resources and information: v. 182, BLM/BC/ST-98/001+1165, March 1998. Accessed September 27, 2010, at URL http://www.blm.gov/natacq/ pls97/index.html

U.S. Bureau of Land Management, 2001, Integrating GIS technologies with the visual resource management inventory process-National Business Office Technical Note 407: Denver, Colorado, Printed Materials Distribution Series, $27 \mathrm{p}$.

U.S. Bureau of Land Management, 2004, Minerals programColorado. Accessed September 27, 2010, at URL http:// www.co.blm.gov/mines/minerals.htm

U.S. Bureau of Land Management, 2009, Rockhounding and fossil collecting: Bureau of Land Management brochure BLM/CO/GI-09-007. Accessed September 24, 2010, at URL http://www.blm.gov/pgdata/etc/medialib/blm/co/ programs/minerals.Par.44677.File.dat/Rockhounding\%20 Brochure.pdf

U.S. Bureau of Mines Branch of Industrial Minerals, 1992, Crystalline silica primer: U.S. Bureau of Mines Special Publication 92-16938, 29 p. Accessed September 27, 2010, at URL http://minerals,usgs.gov/minerals/pubs/commodity/ silica/780292.pdf

U.S. Census Bureau, 2004, Colorado. Accessed September 27, 2010, at URL http://www.census.gov/population/ cencounts/co190090.txt and http://quickfacts.census.gov/ $\mathrm{qfd} /$ states/08000.html

U.S. Department of Agriculture Forest Service, 1995, Landscape aesthetics-A handbook for scenery management: Washington, D.C., U.S. Forest Service, Agricultural Handbook AH-701, 264 p.

U.S. Department of Agriculture Forest Service, 2001, The built environment image guide for the national forests and grasslands: Washington, D.C., U.S. Forest Service, FS-710, 275 p.

U.S. Department of Agriculture Forest Service, 2005, Forest Service-Caring for the land and serving people, $23 \mathrm{p}$. Accessed September 27, 2010, at URL http://www.usda. gov/news/pubs/factbook/010a.pdf

U.S. Department of Agriculture Forest Service, 2010a, Minerals and geology: USDA Forest Service Rocky Mountain Region. Accessed September 27, 2010, at URL http://www.fs.fed.us/r2/resources/mgr/minerals/ index.shtml

U.S. Department of Agriculture Forest Service, 2010b, Minerals and geology program-Laws and regulations. Accessed September 27, 2010, at URL http://www.fs.fed.us/r2/ resources/mgr/laws/index.shtml
U.S. Department of the Interior National Atlas of the United States, 2005, The public land survey system (PLSS). Accessed September 27, 2010, at URL http://www. nationalatlas.gov/articles/boundaries/a_plss.html

U.S. Department of the Interior National Park Service, 2001, Natural resource management reference manual 77: Washington, D.C.

U.S. Department of the Interior National Park Service, 2004, National Register of Historic Places. Accessed September 27, 2010, at URL http://www.historicdistricts.com

U.S. Department of Labor, 2002, Crystalline silica exposure: U.S. Department of Labor, Occupational Safety and Health Administration Publication 3176. Accessed September 27, 2010, at URL http://www.osha.gov/Publications/3176-2002English.html

U.S. Energy Information Administration, 1998, Natural gas and the environment. Accessed November 18, 2010, at URL http://www.eia.doe.gov/pub/oil_gas/natural_gas/ analysis_publications/natural_gas_1998_issues_trends/ pdf/chapter2.pdf

U.S. Environmental Protection Agency, 1995a, Profile of the non-fuel, non-metal mining industry: Washington, D.C., U.S. Government Printing Office, publication EPA/310R-95-011, 95 p. Accessed September 27, 2010, at URL http://www.epa.gov/compliance/resources/publications/ assistance/sectors/notebooks/nomtmisn.pdf

U.S. Environmental Protection Agency Office of Solid Waste, 1995b, Lightweight aggregate production and air pollution control wastes, 15 p. Accessed September 27, 2010, at URL http://www.epa.gov/wastes/nonhaz/industrial/special/ mining/minedock/light/lwa.pdf

U.S. Environmental Protection Agency, 1995c, AP-42 (5th ed.), v. 1, chapter 11, Mineral products industry. Accessed September 27, 2010, at URL http://www.epa.gov/ttnchie1/ ap42/ch11/final/c11s00.pdf

U.S. Environmental Protection Agency, 2002, Sulfur, 10 p. Accessed October 4, 2008 at URL http://www.epa.gov/ wastes/nonhaz/industrial/special/mining/minedock/id/id4sulf.pdf

U.S. Environmental Protection Agency, 2010, Vermiculite. Accessed September 27, 2010, at URL http://www.epa.gov/ opptintr/asbestos/pubs/verm.html

U.S. Geological Survey, 2000, Photo glossary of volcano terms. Accessed September 27, 2010, at URL http:// volcanoes.usgs.gov/images/pglossary/index.php

U.S. Geological Survey, 2003a, The mineral industry of Colorado, in U.S. Geological Survey minerals yearbook 2003, 11 p. Accessed January 26, 2005, at URL http://minerals.usgs. gov/minerals/pubs/state/2003/costmyb03.pdf 
U.S. Geological Survey, 2003b, Igneous rocks. Accessed September 27, 2010, at URL http://vulcan.wr.usgs.gov/ LivingWith/VolcanicPast/Notes/igneous_rocks.html

U.S. Geological Survey, 2004, Mineral commodity summaries 2004: Washington, D.C., U.S. Government Printing Office, $197 \mathrm{p}$.

U.S. Geological Survey, 2006, Stone, dimension, in U.S. Geological Survey 2006 minerals yearbook, 14 p. Accessed September 30, 2010, at URL http://minerals.usgs.gov/minerals/ pubs/commodity/stone_dimension/myb1-2006-stond.pdf

U.S. Senate, 2003, The Bankhead-Jones Farm Tenant Act. Accessed September 27, 2010, at URL http://agriculture. senate.gov/Legislation/Compilations/Forests/bankhead.pdf

Van Alstine, R.E., 1969, Geology and mineral deposits of the Poncha Springs NE quadrangle, Chaffee County, Colorado: U.S. Geological Survey Professional Paper 626, 52 p.

Van Gosen, B.S., and Bush, A.L., 2001, Colorado vermiculite deposits-Mines, prospects, and occurrences: U.S. Geological Survey Open-File Report OF-01-475, 11p.

Van Gosen, B.S., Lowers, H.A., Bush, A.L., Meeker, G.P., Plumlee, G.S., Brownfield, I.K., and Sutley, S.J., 2002, Reconnaissance study of the geology of U.S. vermiculite deposits-Are asbestos minerals common constituents?: U.S. Geological Survey Bulletin 2192, 8 p.

Vanderwilt, J.W., 1947, Metals, nonmetals, and fuels, Pt. 1, in Vanderwilt, J.W., ed., Mineral resources of Colorado: Denver, State of Colorado Mineral Resources Board, 290 p.

Virta, R.L., 2003, Zeolites, 4 p. Accessed October 28, 2004 , at URL http://minerals.usgs.gov/minerals/pubs/commodity/ zeolites/zeolimyb03.pdf

Virta, R.L., 2004, Clays, in U.S. Geological Survey mineral commodity summaries 2004: Washington, D.C., U.S. Government Printing Office, p. 48-49.

Waage, K.M., 1953, Refractory clay deposits of south-central Colorado: U.S. Geological Survey Bulletin 993, 104 p.

WBB Minerals, 2005, Education Centre-Ball clay or china clay? Accessed September 27, 2010, at URL http://www. wbbminerals.net/education_centre/ball_china.html

Wentworth, C.K., 1922, A scale of grade and class terms for clastic sediments: Journal of Geology, v. 30, p. 377-392.

Werth, J.T., 1993, Sand and gravel resources—Protection, regulation, and reclamation: Washington D.C., American Planning Association Planning Advisory Service Report 347, 33 p.

Western Governors' Association, 2010, WGA Policy Resolution 10-16-National minerals policy, 3 p. Accessed September 28, 2010, at URL http://www.westgov. org/index.php?option $=$ com_joomdoc\&task $=d o C_{-}$ details\&gid $=1275 \&$ Itemid $=85$
Wherrett, J.R., 2000, Creating landscape preference models using Internet survey techniques: Landscape Research, v. 25, no. 1, p. 79-96.

Wilburn, David, Goonan, Thomas, and Bleiwas, Donald, 2001, Technological advancement-A factor in increasing resource use: U.S. Geological Survey Open-File Report 01-197. Accessed January 19, 2005, at URL http://pubs. usgs.gov/of/of01-197/html

Winterhalder, Keith, Clewell, A.F., and Aronson, James, 2004, Values and science in ecological restoration-A response to Davis and Slobodkin: Restoration Ecology, v. 12 , no. 1 , p. $4-7$.

Withington, C.F., 1964, Gypsum and anhydrite, in Mineral and water resources of Colorado-Report of the United States Geological Survey in collaboration with the Colorado Mining Industrial Development Board: Washington, D.C., U.S. Government Printing Office, p. 190-197.

Wohl, E.E., 2001, Virtual rivers-Lessons from the mountain rivers of the Colorado Front Range: New Haven, Yale University Press, $210 \mathrm{p}$.

Wolfe, J.A., 1964, Cement rock, in Mineral and water resources of Colorado-Report of the United States Geological Survey in collaboration with the Colorado Mining Industrial Development Board: Washington, D.C., U.S. Government Printing Office, p. 181-183.

Workman, W.E., 1964, Barite from the White River Formation of northeastern Colorado: Charlottesville, University of Virginia, Bachelor of Arts thesis.

Wright, M.A. and White, Susan, eds., 2004, The practical guide to reclamation in Utah: Utah Department of Natural Resources Division of Oil, Gas, and Mining, 163 p. Accessed on September 28, 2010, at URL http://fs.ogm.utah.gov/pub/ MINES/Coal_Related/RecMan/Reclamation_Manual.pdf

Xu, Feng, Mittelhammer, R.L., and Barkley, P.W., 1993, Measuring the contributions of site characteristics to the value of agricultural land: Land Economics, v. 69, no. 4, p. 356-369.

Zdunczyk, M.J., and Linkous, M.A., 1994, Industrial sand and sandstone, in Carr, D.D., ed., Industrial minerals and rocks (6th ed.): Littleton, Colorado, Society for Mining, Metallurgy, and Exploration, p. 879-891.

Zongyu, Zhang, Hui, Lin, Jinyeu, Tsou, and Hall, T.W., 2002, Dichotomy between the information inventory and public: Guangzhou, China, Guangzhou Urban Planning Bureau, 21 p. Accessed on September 28, 2010, at URL http://www. epa.com.tw/landscape/landscape\%20assessment.pdf

Zube, E.H., Brush, R.O., and Fabos, J.G., 1975, Landscape assessment - Values, perceptions, and resources: Stroudsburg, Pa., Dowden, Hutchinson \& Ross, 367 p. 
Publishing support provided by:

Denver Publishing Service Center

For more information concerning this publication, contact: Center Director, USGS Central Mineral and Environmental Resources Science Center

Box 25046, Mail Stop 973

Denver, CO 80225

(303) 236-1562

Or visit the Central Mineral and Environmental Resources Science Center Web site at: http://minerals.cr.usgs.gov/ 


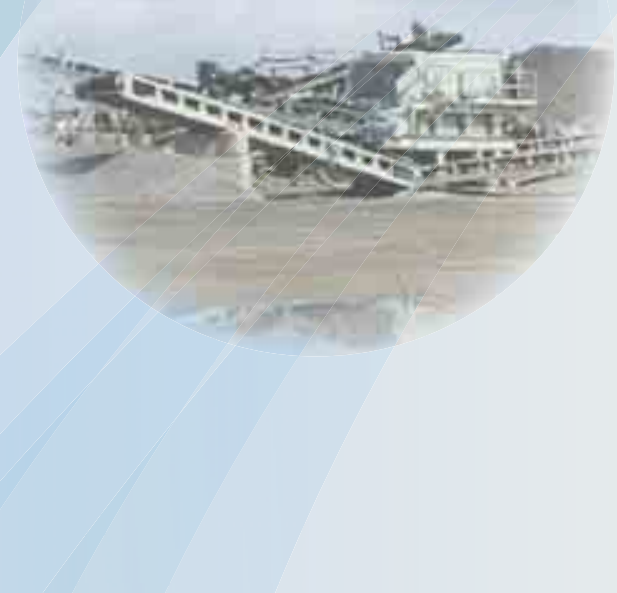

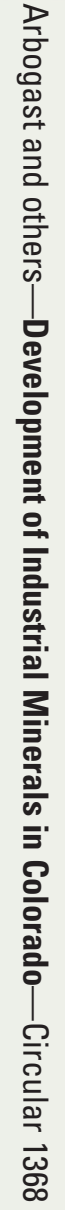

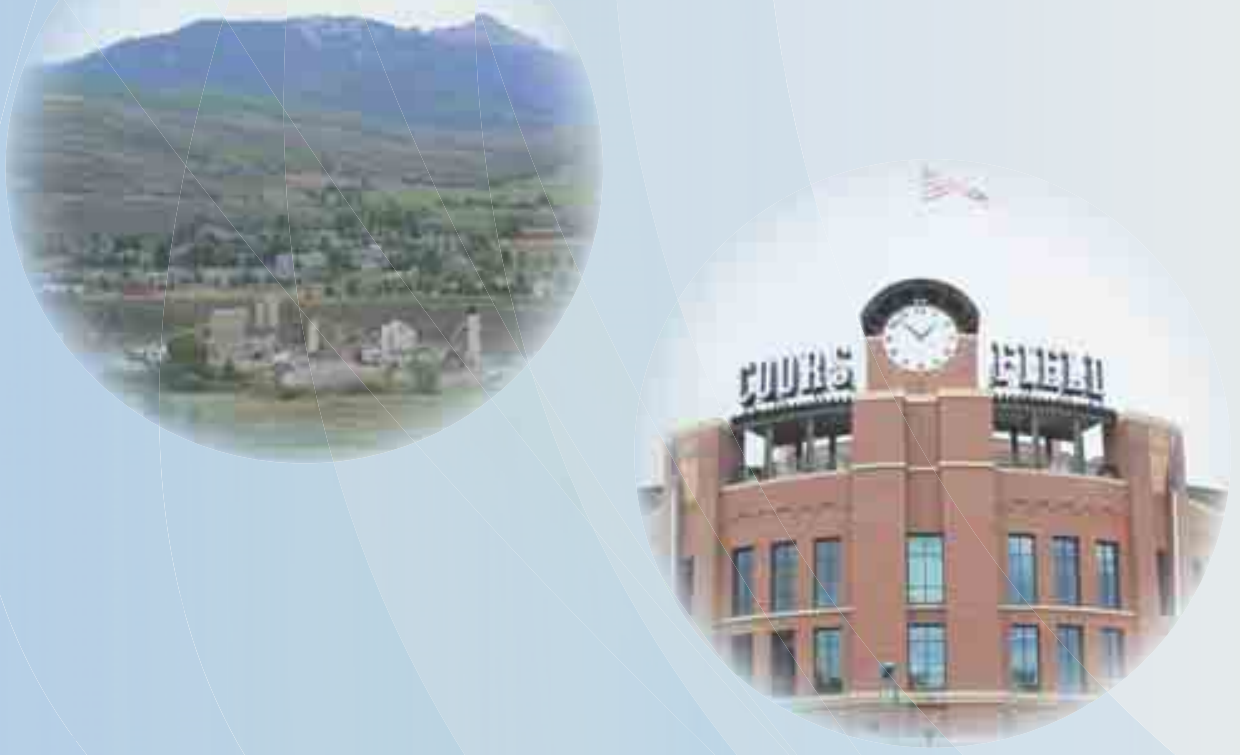

